PHANEROZOIC

VERTICAL

MOVEMENTS

IN MOROCCO

RÉMI J. G. CHARTON 

Phanerozoic Vertical Movements in Morocco 


\section{Phanerozoic Vertical Movements in Morocco}

\section{Dissertation}

for the purpose of obtaining the degree of doctor

at Delft University of Technology

by the authority of the Rector Magnificus Prof. dr. ir. T.H.J.J. van der Hagen;

Chair of the Board for Doctorates

to be defended publicly on

22 May 2018 at 12:30 o'clock

by

\section{Rémi Jean Georges CHARTON}

Master of Science in Environment, Earth, Evolution, and Climate (Geobiosphere),

University of Troms $\varnothing$ (Norway)

\& University of Burgundy (France)

Born in Dijon, France 
This dissertation has been approved by the promotors and the copromotor.

Composition of the doctoral committee:

Rector Magnificus

Prof. Dr. G. Bertotti

Prof. Dr. J. Redfern

Dr. J.E.A. Storms

Independent members:

Prof. Dr. A. Martinius

Prof. Dr. A. Teixell

Dr. D. Rouby

Dr. M. Gouiza

Reserve member:

Prof. Dr. D. Bruhn

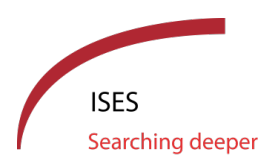

chairman

promotor | TU Delft

promotor | University of Manchester copromotor | TU Delft

TU Delft

University Autònoma de Barcelona

University of Toulouse

University of Leeds

TU Delft
North Africa Research Group

www.narg.org.uk

Keywords: Morocco, vertical movements, low-temperature thermochronology, and timetemperature modelling

Printed by: ProefschriftMaken || www.proefschriftmaken.nl

Cover: Central Atlantic conjugate margins (data: GEBCO_2014_1D)

Copyright (C) 2018 by R. J. G. Charton

ISBN 978-94-6186-913-5

An electronic version of this dissertation is available at

http://repository.tudelft.nl/ 


\section{Summary (vi)}

\section{Samenvatting (vi)}

\section{Introduction (2)}

1.1. Scope of the Thesis (3)

1.2. Thesis Outline (7)

1.3. Geography and geological history of Morocco (9)

2 The Sidi Ifni transect across the rifted margin of Morocco (16)

2.1. Introduction (17)

2.2. Present-day architecture of the Sidi Ifni transect (17)

2.3. LTT and time-Temperature modelling: Methods and results (21)

2.4. Post-Variscan evolution of the Sidi Ifni transect (27)

2.5. Conclusions (29)

3 Post-Variscan evolution and thermal history of the Anti-Atlas (32)

3.1. Introduction (33)

3.2. Geological setting of the Anti-Atlas (35)

3.3. LTT method and results (39)

3.4. Modelled Meso-Cenozoic thermal history of the Anti-Atlas (46)

3.5. Geological evolution and thermal transects of the Anti-Atlas (55)

3.6. Conclusions (61)

4 A quantitative study of Post-Variscan vertical movements in Morocco (64)

4.1. Introduction (65)

4.2. Vertical movement databases (66)

4.3. Exhumation and subsidence rates (72)

4.4. Exhumation maps and eroded material fluxes (78)

4.5. Exhumation and subsidence evolution (84)

4.6. Conclusions (87) 
5 A qualitative study of the Phanerozoic source-to-sink systems (90)

5.1. Introduction (91)

5.2. Data used to construct the source-to-sink maps (92)

5.3. Source-to-sink maps (97)

5.4. Limitations (110)

5.5. Conclusions (111)

6 Discussion: Vertical movements and underlying mechanisms (114)

6.1. Introduction (115)

6.2. Expected tectonic evolution along a rifted passive margin (115)

6.3. LTT age patterns: A link with rifting or drifting processes? (118)

6.4. Vertical movements: Proposed mechanisms (123)

6.5. Characteristics of the upward movements: Insights from this Thesis (125)

6.6. Compilation of tectonic, climatic, and eustatic proxies vs this Thesis (133)

6.7. Conclusions (135)

7 Conclusion (138)

7.1. Summary of this Thesis (139)

7.2. Further investigation (140)

References (145)

Acknowledgements (163)

Curriculum Vitae (165)

Publications (165) 


\section{Summary}

Our understanding of the Earth's interior is limited by the access we have of its deep layers, while the knowledge we have of Earth's evolution is restricted to harvested information from the present state of our planet. We therefore use proxies, physical and numerical models, and observations made on and from the surface of the Earth. The landscape results from a combination of processes operating at the surface and in the subsurface. Thus, if one knows how to read the landscape, one may unfold its geological evolution.

In the past decade, numerous studies have documented $\mathrm{km}$-scale upward and downward vertical movements in the continental rifted margins of the Atlantic Ocean and in their hinterlands. These movements, described as exhumation (upward) and subsidence (downward), have been labelled as "unpredicted" and/or "unexpected". 'Unpredicted' because conceptual, physical, and numerical models that we dispose of for the evolution of continental margins do not generally account for these relatively recent observations. 'Unexpected' because the $\mathrm{km}$-scale vertical movements occurred when our record of the geological history is insufficient to support them. As yet, the mechanisms responsible for the $\mathrm{km}$-scale vertical movements remain enigmatic.

One of the common techniques used by geoscientists to investigate the past kinematics of the continental crust is to couple 'low-temperature thermochronology' and 'timetemperature modelling'. In Morocco alone, over twenty studies were conducted following this approach. The reason behind this abundance of studies and the related enthusiasm of researchers towards Moroccan geology is due to its puzzling landscapes and complex history. In this Thesis, we investigate unconstrained aspects of the kmscale vertical movements that occurred in Morocco and its surroundings (Canary Islands, Algeria, Mali, and Mauritania).

The transition area between generally subsiding domains and mostly exhuming domains, yet poorly understood, is discussed via the evolution of a profile, running across the rifted continental margin (chapter 2). Low-temperature thermochronology data from the central Morocco coastal area document a km-scale exhumation between the Permian and the Early/Middle Jurassic. The related erosion fed sediments to the subsiding Mesozoic basin to the northwest. Basement rocks along the transect were subsequently buried between the Late Jurassic and the Early Cretaceous. From late Early/Late Cretaceous onwards, rocks present along the transect were exhumed to their present-day position. 
The post-Variscan thermal and geological history of the Anti-Atlas belt in central Morocco is constrained with a transect constructed along strike of the belt (chapter 3 ). The initial episode occurred in the Late Triassic and led to a km-scale exhumation of crustal rocks by the end of the Middle Jurassic. The following phase was characterised by basement subsidence and occurred during the Late Jurassic and most of the Early Cretaceous. The basement rocks were then slowly brought to the surface after experiencing a km-scale exhumation throughout the Late Cretaceous and the Cenozoic. The exhumation episodes extended into the interior of the African tectonic plate, perhaps beyond the sampled belt itself.

Exhumation rates and fluxes of material eroded from the hinterlands of the Moroccan rifted margin were quantified from the Permian (chapter 4). The high denudation rates, obtained in central Morocco during the Early to Middle Jurassic and in northern Morocco during the Neogene, are comparable to values typical of rift flank, domal, or structural uplifts. These are obtained in central Morocco during the Early to Middle Jurassic and in northern Morocco during the Neogene. Exhumation rates for other periods in northern to southern Morocco average around 'normal' denudation values. Periods of high production of sediments in the investigated source areas are the Permian, the Jurassic, the Early Cretaceous, and the Neogene

The Phanerozoic evolution of source-to-sink systems in Morocco and surroundings is illustrated in several maps (chapter 5). Substantial shifts in the source areas were evidenced between the central and northern Moroccan domains during the Middle-Late Jurassic and between the Meseta and the Anti-Atlas during the Early-Late Cretaceous.

Finally, the mechanisms responsible for the onset and subsistence of the unpredicted $\mathrm{km}$-scale vertical movements are discussed (chapter 6). We propose that a combination of the large-scale crustal folding, mantle-driven dynamic topography, and thermal subsidence, superimposed to changes in climates, sea level and erodibility of the exposed rocks, were crucial to the timing, amplitude, and style of the observed vertical movements.

The km-scale vertical movements will continue to be studied for years to come. Expectantly, this Thesis will deliver sufficiently robust grounds for further elaborated and integrated studies in Morocco and beyond. 


\section{Samenvatting}

Ons begrip van het binnenste van de aarde wordt beperkt door de toegang die we ertoe hebben, terwijl ons beeld van haar evolutie beperkt is tot de huidige staat. We moeten vertrouwen op proxy's, fysische en numerieke modellen en observaties op het aardoppervlak. De topografie is zo'n proxy, omdat dat het resultaat is van de combinatie van processen aan de oppervlakte en in de ondergrond. Dus wanneer iemand het landschap kan lezen, kan men de geologische evolutie ervan herlezen.

In het afgelopen decennium hebben talrijke studies de opwaartse en neerwaartse verticale bewegingen in de continentale riftmarges van de Atlantische Oceaan en hun achterland op een schaal van kilometers gedocumenteerd. Deze bewegingen, omschreven als opheffing (omhoog) en daling (naar beneden), zijn aangemerkt als 'onvoorspelbaar' en/of 'onverwacht'; 'onvoorspelbaar' omdat de conceptuele, fysische en numerieke modellen die we gebruiken voor de evolutie van continentale marges deze relatief recente waarnemingen over het algemeen niet bevatten; 'onverwacht' omdat de verticale bewegingen onvoldoende verklaard worden door onze geologische geschiedenis. Vooralsnog blijven de mechanismen die verantwoordelijk zijn voor deze verticale bewegingen op een schaal van kilometers enigmatisch.

Een van de gebruikelijke methoden die door geowetenschappers worden gebruikt om de kinematiek van de continentale korst te onderzoeken is thermochronologie bij lage temperatuur in combinatie met tijd-temperatuurmodellering. In Marokko alleen al werden ongeveer twintig studies uitgevoerd met gebruikmaking van deze benadering. De reden voor deze overvloed aan studies en het daaraan verbonden enthousiasme over de Marokkaanse geologie is te danken aan de raadselachtige landschappen en complexe geschiedenis. In dit proefschrift onderzoeken we onbekende aspecten van de verticale bewegingen die zich op een schaal van kilometers hebben voorgedaan in Marokko en omstreken (de Canarische Eilanden, Algerije, Mali en Mauritanië).

Het overgangsgebied tussen stijgende en dalende domeinen wordt beschreven aan de hand van de evolutie van de Sidi Ifni-doorsnede die over de verschoven continentale marge loopt (hoofdstuk 2). Lage-temperatuurs thermochronologiegegevens uit het kustgebied van de Anti-Atlas documenteren een opheffing op een schaal van kilometers tussen het Perm en het Vroeg/Midden Jura. De daarmee samenhangende erosie voedde sediment aan het dalende Mesozoïsche bekken in het noordwesten. Sokkelgesteente langs de doorsnede werd begraven tussen het Laat Jura en het Vroeg Krijt. Vanaf het Vroeg/Laat Krijt werd het gesteente dat aanwezig is langs de doorsnede opgeheven tot zijn huidige positie. 
De post-Hercynische thermische en geologische geschiedenis van de Anti-Atlasgordel wordt vastgelegd door een doorsnede langs de as van het gebergte (hoofdstuk 3). De eerste episode vond plaats in het Laat Trias en leidde tot een opheffing van korstgesteente op een schaal van kilometers tegen het einde van het Midden Jura. De volgende fase resulteerde in daling van de sokkel gedurende het Late Jura en het grootste deel van het Vroeg Krijt. Het sokkelgesteente werden vervolgens langzaam naar de oppervlakte gebracht gedurende een opheffing op een schaal van kilometers in het Laat Krijt en het Cenozoïcum. De opheffingsfasen strekten zich uit tot in het midden van de Afrikaanse tektonische plaat en misschien buiten de bemonsterde gordel zelf.

De opheffingssnelheden en sedimentaanvoer zijn gekwantificeerd vanaf het Perm (hoofdstuk 4). De hoge denudatiesnelheden zijn vergelijkbaar met waarden die geassocieerd worden met riftflanken en thermisch aangedreven koepelvormige of structurele opheffingen. Dergelijke snelheden worden gezien in de Anti-Atlas tijdens het Vroeg Jura en in de Hoge Atlas en Rif tijdens het Neogeen. Opheffingssnelheden voor andere perioden in de Meseta, Hoge Atlas, Anti-Atlas en het Reguibatschild zijn gemiddelden rond de normale denudatiewaarden. Periodes van hoge sedimentproductie in de onderzochte brongebieden zijn het Perm, het Jura, het Vroeg Krijg en het Neogeen

De Phanerozoïsche evolutie van bron-bekken systemen in Marokko en omgeving wordt geïllustreerd in verschillende kaarten (Hoofdstuk 5). Aanzienlijke veranderingen van brongebieden zijn aangetoond tussen de Anti-Atlas en Meseta-domeinen vanaf het Midden tot Laat Krijt en tussen de Meseta en Anti-Atlas vanaf het Vroeg tot Midden/Laat Krijt

Tot slot worden de structuren die verantwoordelijk zijn voor het ontstaan en het voortzetten van de onvoorspelbare verticale bewegingen op een schaal van kilometers geanalyseerd (hoofdstuk 6). We stellen een combinatie voor van grootschalige korstvervouwing, door de mantel aangedreven dynamiek in topografie, en thermische bodemdaling, bovenop op het klimaat, zeeniveau en erodeerbaarheid van het blootgestelde gesteente, droegen bij aan de timing van verticale bewegingen, patronen en amplitudes zoals waargenomen in Marokko en omstreken.

De verticale bewegingen op een schaal van kilometers zullen nog vele jaren bestudeerd worden. Hopelijk levert dit proefschrift een solide basis voor een verdere uitwerking en geïntegreerde studies. 



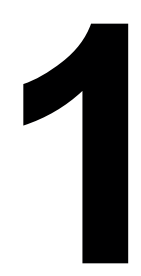

Introduction 


\subsection{Scope of the Thesis}

The present-day landscape is the result of a finite amount of processes operating at the surface and in the subsurface of the Earth. These processes are numerous, complex, and, perhaps more importantly, not fully understood. One of the challenges in geoscience over the last decades has been to define and quantify the evolution of continental margins (fig. 1.1).

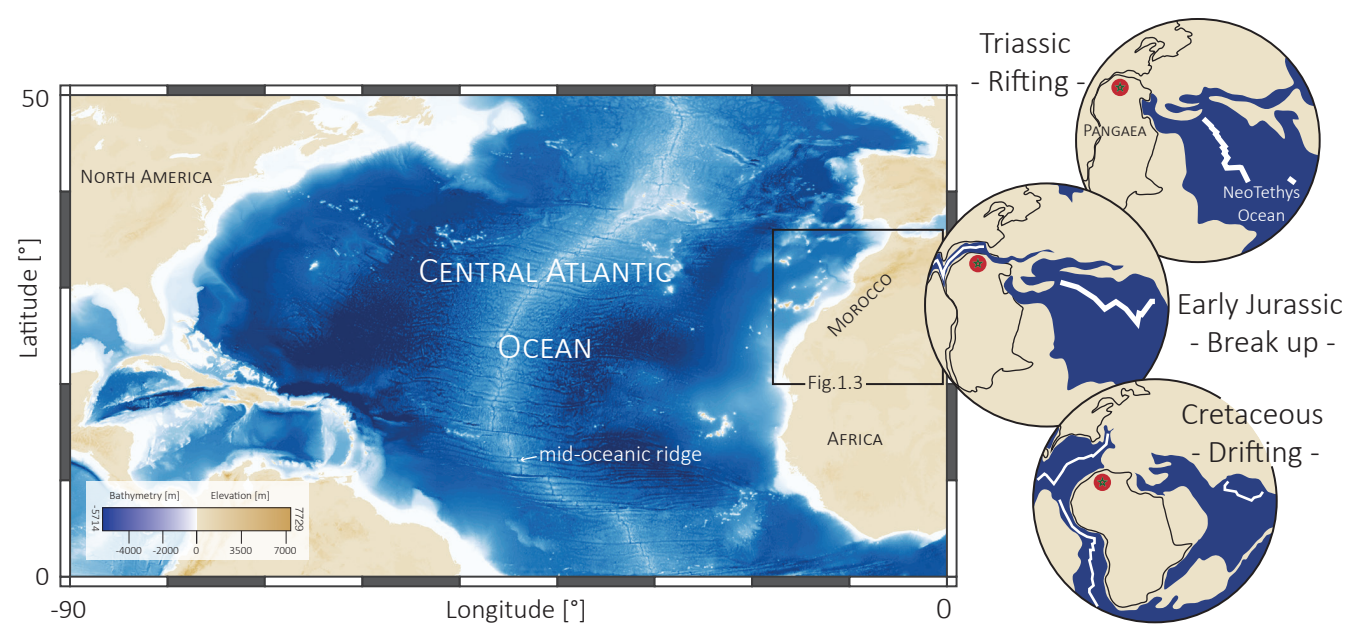

Figure 1.1. Morphology of the Central Atlantic seafloor and conjugate margins (data: GEBCO_2014_1D). The simplified plate tectonic evolution is after Stampfli and Borel (2002).

In the case of passive rifting (Allen and Allen, 2013), existing models state that the rift zone and flanks are characterised by lithospheric stretching, high surface heat-flow, seismic activity, negative Bouguer anomalies, thermal anomaly at depth, and may be affected by volcanism and flank uplift. The latter occurs along the footwall of faults of the rift. Syn-rift flank uplift may extend over $100 \mathrm{~km}$ into the unstretched crust, reaching up to $1 \mathrm{~km}$ in elevation and leading to intensified erosion (e.g. Allen and Allen, 2013). Lithosphere kinematic models characterise the post-rift stage by slow cooling following the continental break-up and thermal contraction (i.e. thermal subsidence). As observed by Japsen et al. (2012a), the continental crust adjacent to passive margins have frequently been described as shoulder uplifts during their syn-rift stage and as tectonically quiescent during their post-rift stage. Furthermore, this assumed inactivity agrees with most conceptual, physical, and numerical models that we dispose of for the evolution of passive margins (reviewed in Watts, 2012).

Continental passive margins and their hinterlands, especially in the Atlantic realm, are the locus of a significant amount of studies that evidence pre-, syn-, and post-rift episodic km-scale upward (i.e. exhumation) and downward (i.e. subsidence) movements (e.g. Green et al.,2018). Pre-rift exhumation episodes are recorded in the vicinity of the future Atlantic Ocean (e.g. Juez-Larre and Andriessen, 2006; Ruiz et al., 2011; Jelinek et al., 2014; Japsen et al., 2016a). Syn-rift exhumation episodes have been described in the 
Atlantic rift flanks (e.g. Oukassou et al., 2013; Jelinek et al., 2014; Wildman et al., 2015; Japsen et al., 2016a), while syn-rift subsidence episodes have been documented in fewer places (e.g. Juez-Larre and Andriessen, 2006; Ghorbal et al., 2008). Post-rift kmscale vertical movements have been documented along the North (e.g. Japsen et al., 2006; Japsen et al., 2016a;b), Central (e.g. Bertotti and Gouiza, 2012; Amidon et al., 2016) and South (e.g. Jelinek et al., 2014; Wildman et al., 2015) Atlantic margins. Beyond the Atlantic realm, Australian margins have experienced similar movements (e.g. Tassone et al., 2012).

Although all the above mentioned studies were keen to investigate the exhumation episodes, very few focused on the subsidence events. The latter are important because in many places thick sediment series have been deposited and then removed. This impacted not only the thermal history of the substratum, but also the source-to-sink systems fed by the removal of these sequences. Moreover, a link must exist between domains undergoing coeval opposite vertical movements. As several studies conducted in the margins of the Central Atlantic have already proposed (e.g. Bertotti and Gouiza, 2012), anomalous vertical movements in the exhuming domain are coeval to excessive downward movements in the subsiding domain.

Exhumation and subsidence episodes occur in regions characterised by both stretched and non-stretched lithosphere, demonstrating that other processes extrinsic to the rifting are at work, or that the effects of the rifting and drifting outreached their margins. Several authors have qualitatively tested aspects of these vertical movements with numerical models (e.g. Leroy et al., 2008; Gouiza, 2011; Yamato et al., 2013). However, to better constrain the models, a quantification of these movements over geological time and, more importantly, at the scale of the margin is required.

Vast regions along rifted continental margins are characterised by the exposure of prerift rocks (e.g. in Norway, Canada, Greenland, Morocco, Mauritania, Brazil, Australia...). Low-Temperature Thermochronology (LTT) and time-Temperature ( $\mathrm{t}-\mathrm{T})$ modelling techniques provide understanding of the thermal history of geologically ill-constrained areas characterised by no or little sedimentary records (e.g. Gallagher et al., 1998; Ghorbal et al., 2008; Japsen et al., 2009; Teixell et al., 2009; Japsen et al., 2012b; Jelinek et al., 2014). These techniques are commonly employed as proxies to reconstruct vertical movements (e.g. Teixell et al., 2009). Recent Ph.D. dissertations nicely elaborated on the LTT method (Sehrt, 2014; Leprêtre, 2015; Domènech, 2015). Because the LTT ages record the cooling of rock samples, they are linked either to thermal relaxation and/or exhumation (also called denudation; e.g. Pagel et al., 2014). Hence, LTT ages are recorded shortly after magmatic events, during/after processes linked to the creation of topography (e.g. orogenies, shoulder uplift, thermal doming), and/or during processes leading to enhanced erosion (e.g. climatic and sea level changes).

LTT has been used in many regions around the globe, resulting in very dense data sets for regions characterised by puzzling landscapes such as the elevated continental 
passive margins (e.g. Japsen et al., 2012a), the Himalaya and Alps mountains, and Morocco for instance. Over thirty LTT and time-Temperature (t-T) modelling studies have been conducted in Morocco and its surroundings. There, the large majority of the produced LTT ages spanned the period between the Variscan and Atlas orogenies (ca. 300-40 Ma). They were described as resulting from vertical movements, and have sometimes been labelled as km-scale "unexpected" exhumation and "unpredicted" subsidence episodes, remaining enigmatic to-date (fig. 1.2; e.g. Ghorbal et al., 2008).

The elements of the above-described exhumation and subsidence episodes that are yet to be investigated are: the link between the onshore and offshore movements, their extent away from the rifted margin, their rates, the resulting source-to-sink systems, and the responsible mechanism(s). This Thesis is a contribution to bridge these gaps in our knowledge of the Moroccan, NW African, and Central Atlantic geological evolutions. 

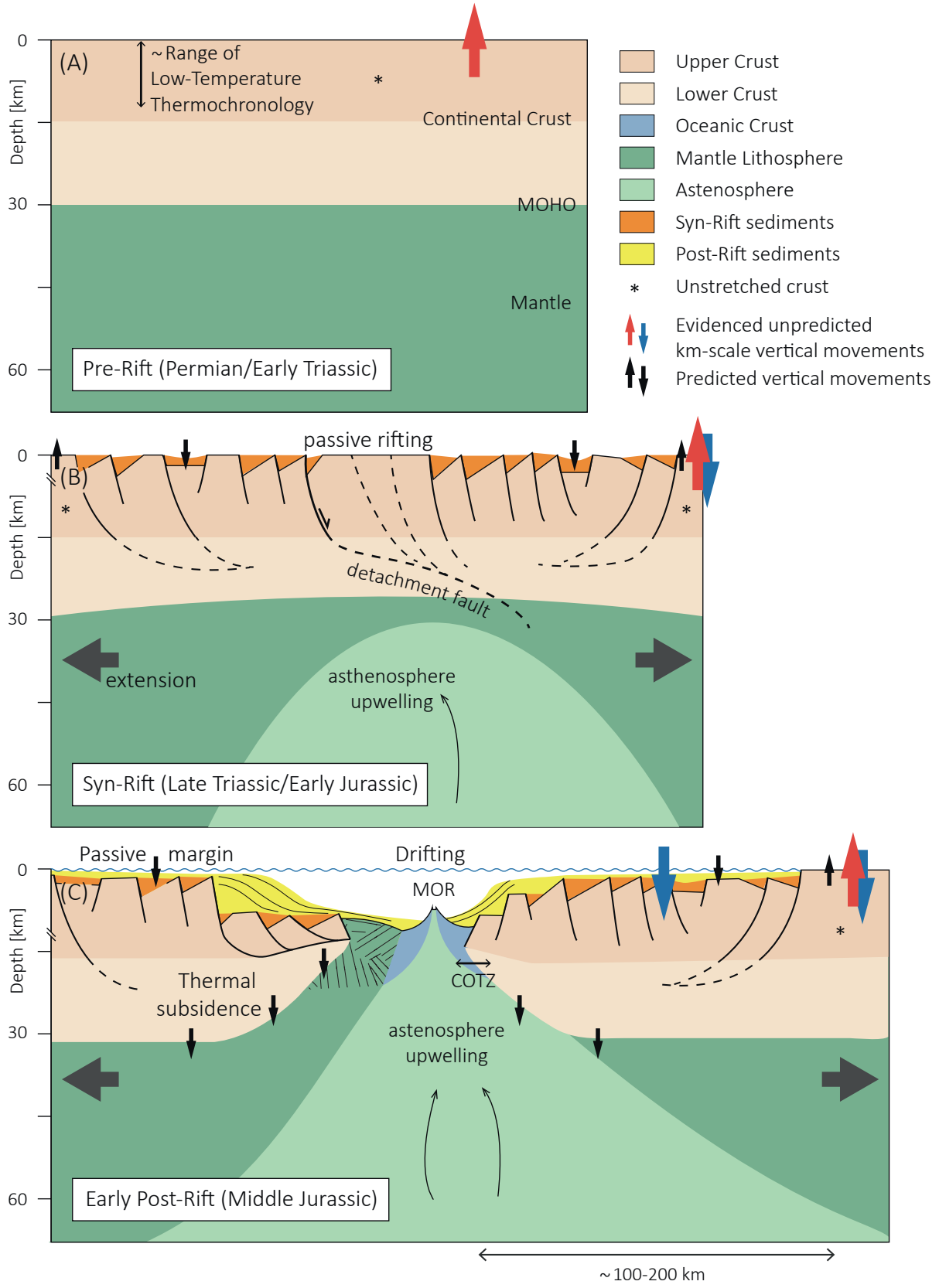

Figure 1.2. Summary of the unexpected $\mathrm{km}$-scale vertical movements observed in the Central Atlantic margins and their adjacent continental crusts (after Gouiza et al., 2010). A), B), and C) Pre-, Syn- and post-rift situations, respectively. MOR: Mid-Oceanic Ridge (spreading centre); COTZ: Continent-Ocean Transition Zone. 


\subsection{Thesis Outline}

This Thesis is composed of seven chapters, starting in the introduction with a general definition of the $\mathrm{km}$-scale vertical movements and followed by the geological history of Morocco (and by extension, of its surroundings: the Central Atlantic Ocean, Algeria, Mauritania, and Mali) (fig. 1.3).

Chapter 2 examines the link between the onshore and offshore domains, along the AntiAtlas coastline, in the Sidi Ifni area. The basement of the rifted margin is outcrping in the Anti-Atlas belt, and has mostly been subsiding since the Late Triassic. We use LTT, seismic, and borehole data, as well as new age control on Mesozoic sediments to document the post-Variscan geological evolution of a transect defined across the rifted margin.

Chapter 3 focuses on the landward extent of the vertical movements along the AntiAtlas. The Anti-Atlas belt extends over more than $600 \mathrm{~km}$, from the Atlantic margin in the west to the interior of the African plate in the east. Along the axis of the belt, Precambrian crystalline basement rocks are outcropping, which allows for the investigation of the thermal history far away from the coast by performing LTT and t-T modelling. Paleo-temperature transects running parallel to the Anti-Atlas trend were then built and used to described the landward wavelength of these movements.

Chapter 4 provides the rates of the vertical movements documented with t-T modelling. For this, all $\mathrm{t}-\mathrm{T}$ modelling best-fit curves are digitized and temperature-to-depth conversion is applied. The exhumation and subsidence rates were then used as input for interpolation at the scale of the margin, in order to quantify the volume of rocks that were eroded during several exhumation episodes.

In chapter 5, we have compiled new findings with an extensive review of existing data in order to build ten source-to-sink maps, from Permian to Neogene. Emphasis is placed on Jurassic and Cretaceous periods. The maps contain well data, outcrop spatial distribution, lithofacies from onshore and offshore basins, provenance study analyses, relevant palaeontological data, and exhumed domains.

In chapter 6, we discuss several aspects of the investigated vertical movements; knowledge which we acquired from the Moroccan rifted margin and adjacent continental crust. In this chapter, we also venture into the complex and elusive task of constraining the mechanism(s) responsible for the vertical movements. 


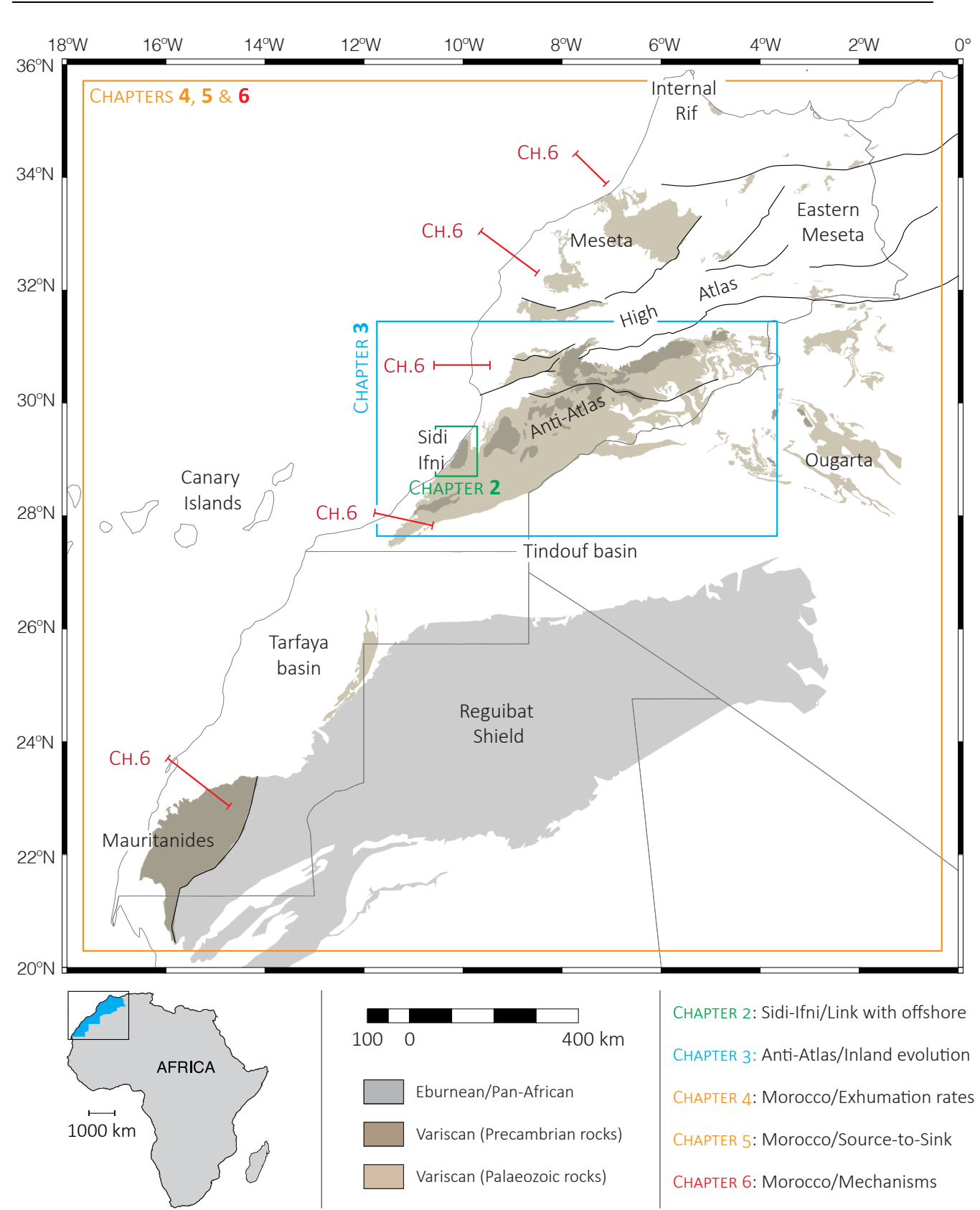

Figure 1.3. Simplified structural map of Morocco and its surroundings with the studied domains covered in each chapter of this Thesis. 
1.3. Geography and geological history of Morocco

\subsubsection{Geography of Morocco}

The Central Atlantic continental margins extend from Morocco to Guinea in the east and Canada to the USA in the west (fig. 1.1; Davison, 2005; Withjack and Schlische, 2005). Morocco, located in Northwest Africa, is characterised by a 'triple junction' offshore Agadir (e.g. Michard et al., 2008) between the Central Atlantic Ocean, the West African Craton, and the Atlas orogenic system. The relief (fig. 1.4) varies from high mountainous regions (Rif and Atlas belts), level high grounds (Hauts Plateaux and Ouarzazate basin), old elevated massifs (Central Massif, Rehamna, Jebilets, Massif Ancient, Anti-Atlas, and Ougarta), non-elevated coastal plains (Meseta, Souss Basin, Tarfaya Basin, and Dakhla Basin), and the Saharan domain (south of the Anti-Atlas) marked by ergs, regs (Reguibat Shield), and sabkhas (salt flats). The Moroccan geology (fig. 1.5) was defined by major events from the Precambrian to the present-day (fig. 1.6).

\subsubsection{Geology of Morocco: Pre-rift}

The Central Atlantic pre-rift period of Morocco is characterised by the Eburnean and Panafrican orogenies during the Paleoproterozoic and Neoproterozoic (Piqué et al., 2006), respectively. These orogenies deformed the oldest sediments of Morocco and the crystalline basement of the Western African Craton, and are exposed in the Reguibat shield, Mauritanides, and in the core of the Anti-Atlas. Marine-dominated sedimentation occurred during the Early Palaeozoic and deposits are preserved and exposed in the Meseta massifs, Anti-Atlas, and Tindouf basin (Michard et al., 2008).

The Late Palaeozoic Variscan orogeny (fig. 1.6; basin inversion, crustal folding, intense thrusting, nappe structures, granitic intrusion...) affected the Palaeozoic cover and Precambrian basement of the Meseta, High Atlas, and Anti-Atlas (e.g. Michard et al., 2010). It was followed in Late Permian to Middle Triassic by post-orogenic collapse (or peneplanation of the belt) constrained in Morocco by the Variscan unconformity (e.g. Frizon de Lamotte et al., 2004). 


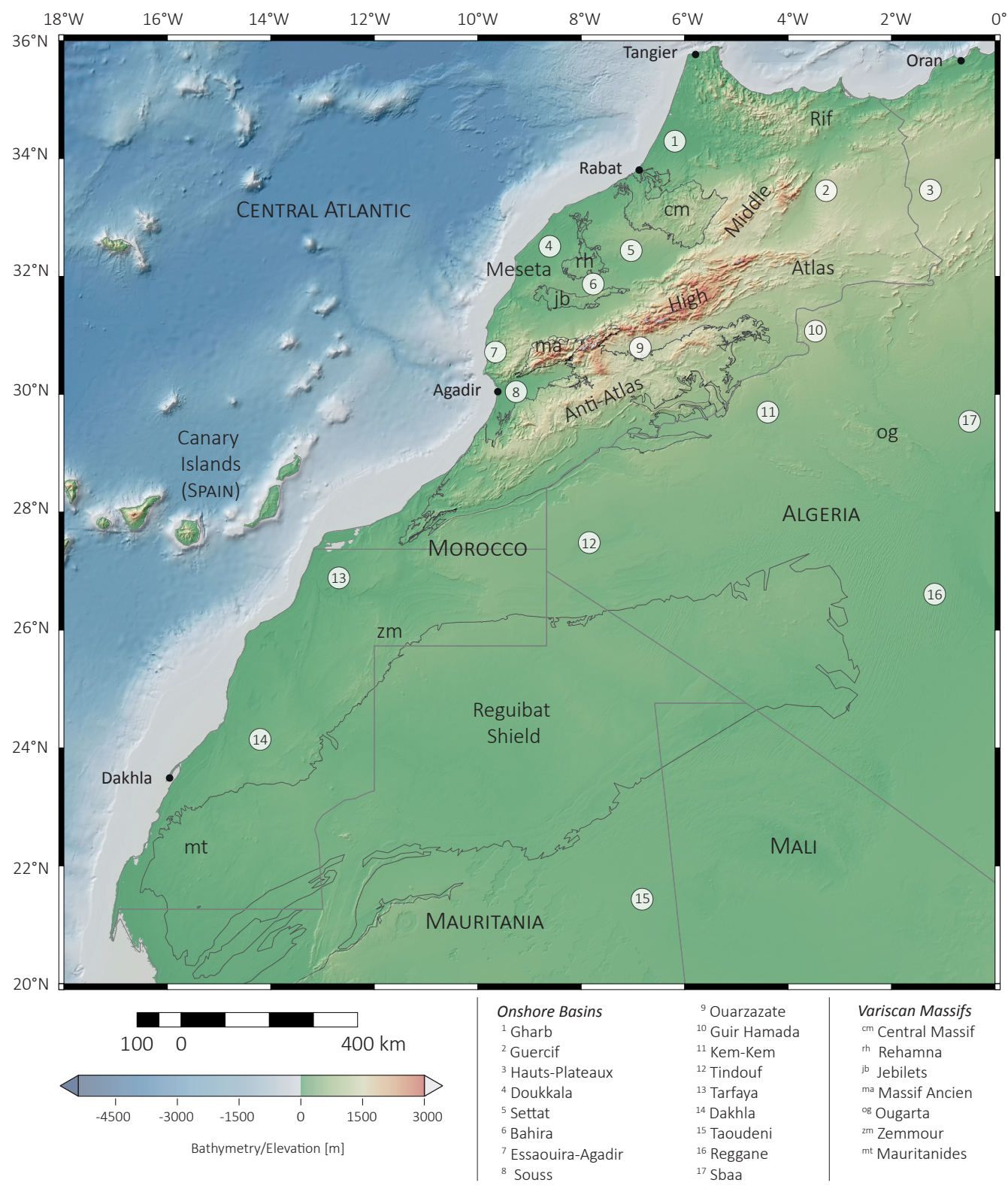

Figure 1.4. Geography of Morocco and its surroundings (data: GEBCO_2014_1D) with main geological domains, sedimentary basins, and Variscan Massifs superimposed. 


\subsubsection{Geology of Morocco: Syn-rift}

Morocco experienced two nearly synchronous episodes of rifting during Triassic and Jurassic times: the Central Atlantic (ca. 230-190 Ma; Labails et al., 2010; Frizon de Lamotte et al., 2015) and Atlasic (ca. 240-185 Ma, aborted; Piqué et al., 2006; fig. 1.6) rifts. The orientation of the Central Atlantic rift is partly inherited from Variscan structures, as rift structures occurred over and parallel to the trend of the Palaeozoic belt. The Atlasic rift belongs to the Tethysian realm and is oriented at ca. $45^{\circ}$ to the Central Atlantic rift (fig. 1.5). In the rift zones, grabens and half graben were filled-up with syn-rift deposits in the Doukkala, Argana/Essaouira-Agadir, Tarfaya coastal basins and High/Middle Atlas basins. At ca. 201 Ma, the Central Atlantic Magmatic Province (CAMP; figs. 1.5 and 1.6) was characterised by the emplacement of mafic dykes and sills, followed by flood basalts dated until ca. 190 Ma (e.g. Davies et al., 2017).

\subsubsection{Geology of Morocco: Post-rift}

The onset of drifting marking the break-up of Pangaea occurred at the beginning of the Jurassic. The precise age is debated between 190 and 170 Ma (e.g. Labails et al., 2010; Davison, 2005). The development of the Moroccan passive margin during the Jurassic and Early Cretaceous witnessed the accumulation of marine and neritic sediments in the present-day offshore, coastal, High/Middle Atlas, and Settat Plateau (Meseta). The PeriAtlantic Alkaline Pulse (PAAP) is recorded by plutons and flood basalt in the conjugate margins of the Central and South Atlantic oceans, between 125 and $80 \mathrm{Ma}$ (Matton and Jebrak, 2009; Montero et al., 2016). The Richat structure in Mauritania and some carbonatites in the Mauritanides are manifestations of the PAAP. Some of the Canaries Island seamounts (fig. 1.4) have been dated between 142 and $91 \mathrm{Ma}$ (van den Bogaard, 2013), overlapping with the timing of the PAAP activity.

The opening of the South Atlantic at ca. $85 \mathrm{Ma}$ led to the African and European plate convergence from the Late Cretaceous to the present-day, and may be responsible for folding and basin inversion in the High and Middle Atlas and in the Rif chains (Guiraud, 1998). The ongoing Atlas orogenesis that peaked in the Eocene is characterised by the deformation and surrection of the Rif, Middle and High Atlas, and of the Anti-Atlas to some extent (Michard et al., 2008). Finally, the Cenozoic volcanism (Missenard and Cadoux, 2011) and surface uplift have been interpreted as being associated to a mantle anomaly (Zeyen et al., 2005; Teixell et al., 2005; Missenard, 2006). Cenozoic volcanism and surface uplift are observed along two axes, from the Canary Islands to the Siroua massif (Anti-Atlas), and from the latter to the Rif belt. 


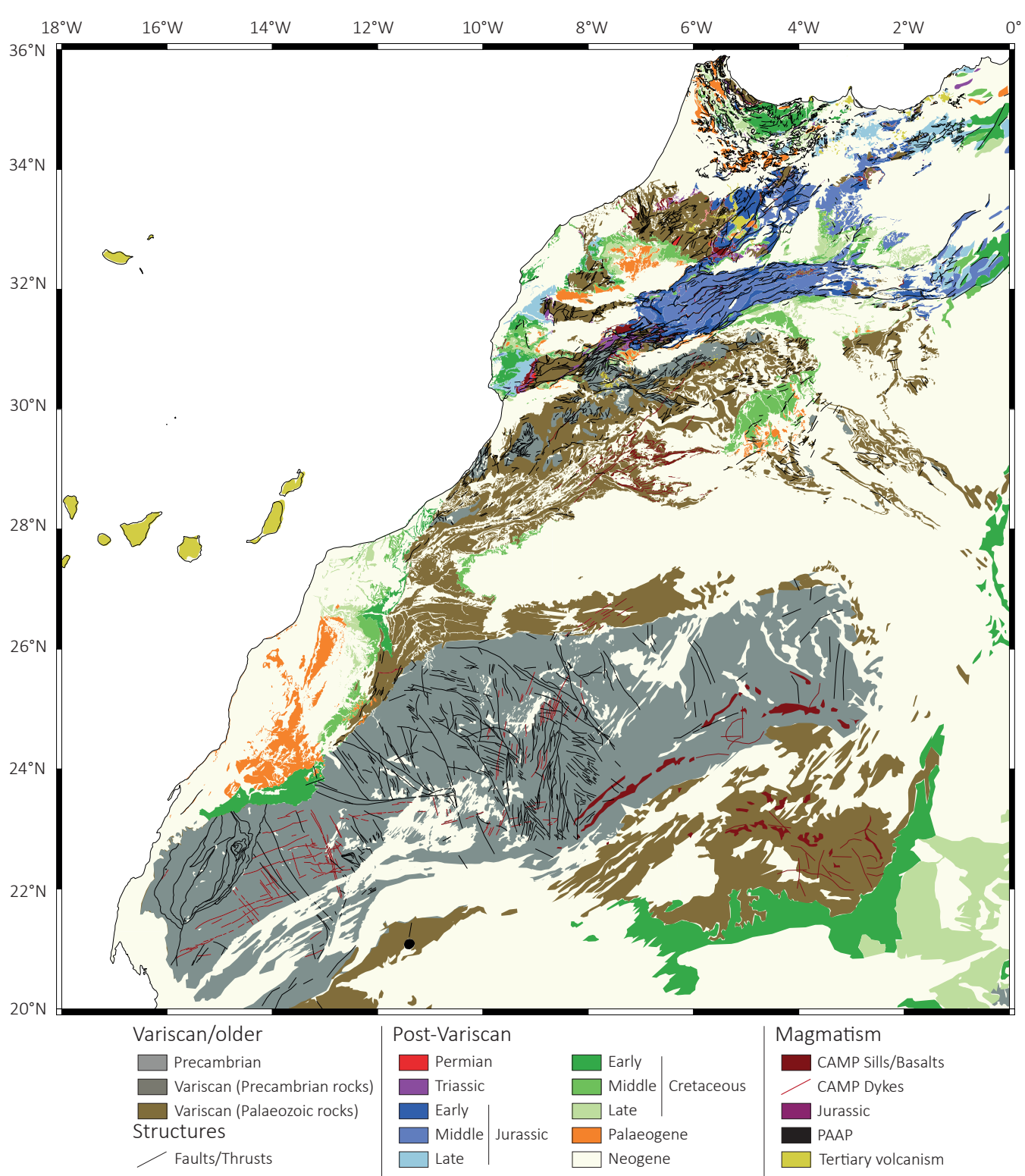

Figure 1.5. Geological map of Morocco and its surroundings (after Hollard et al., 1985). CAMP: Central Atlantic Magmatic Province; PAAP: Peri-Atlantic Alkaline Province. The Cretaceous sediments in Mali (SE corner) are classified in Early and Late Cretaceous, which includes the middle Cretaceous as defined in Morocco. 


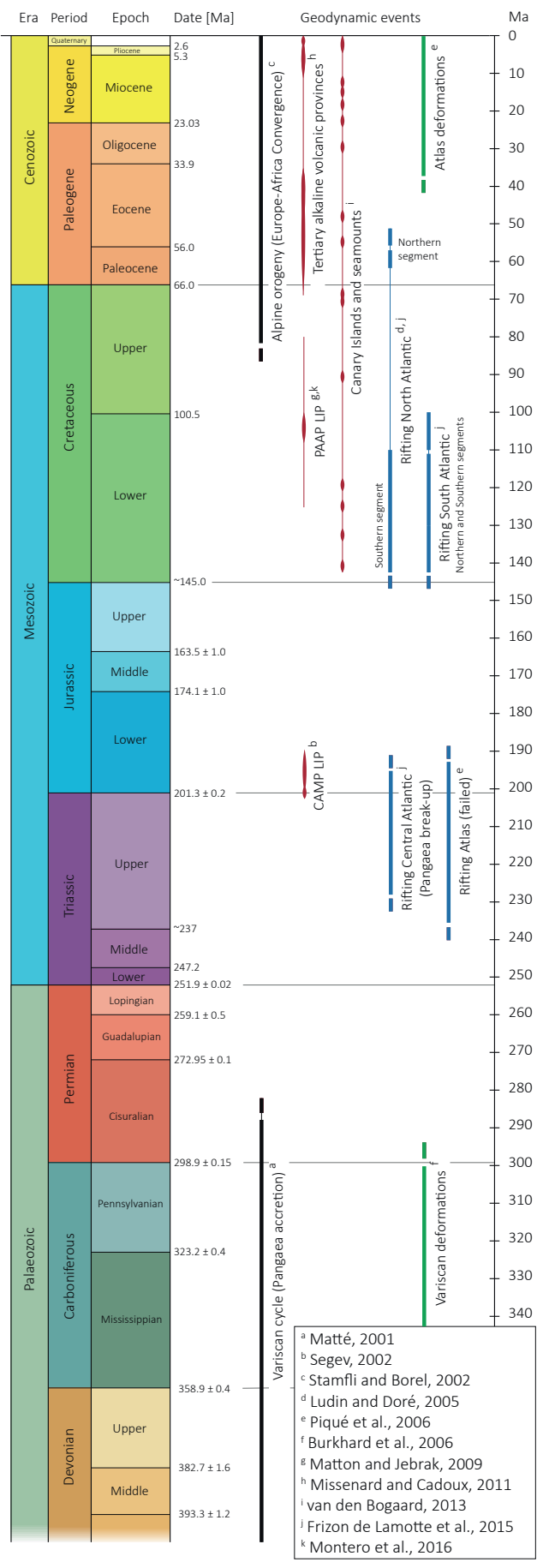

Figure 1.6. Tectonic chart of the Atlantic realm and Morocco, see references therein lages after ICS 2016/12). LIP: Large Igneous Province; CAMP: Central Atlantic Magmatic Province; PAAP: Peri-Atlantic Alkaline Pulse. 
Acknowledgements: Helena van der Vegt is thanked for proofreading this chapter. Pierre-Olivier Bruna is thanked for proofreading the figures. Emilie Chaillan is thanked for digitizing the Cretaceous outcrops from the NW African geological maps. 



\title{
2
}

\section{The Sidi Ifni transect across the rifted margin of Morocco}

\begin{abstract}
The occurrence of km-scale exhumations during syn- and post-rift stages has been documented along Atlantic continental margins, which are also characterised by basins undergoing substantial subsidence. The relationship between the exhuming and subsiding domains is poorly understood. In this study, we reconstruct the evolution of a $50 \mathrm{~km}$ long transect across the Moroccan rifted margin from the western Anti-Atlas to the Atlantic basin offshore the city of Sidi Ifni. Low-temperature thermochronology data from the Sidi Ifni area document a ca. $8 \mathrm{~km}$ exhumation between the Permian and the Early/Middle Jurassic. The related erosion fed sediments to the subsiding Mesozoic basin to the NW. Basement rocks along the transect were subsequently buried by 1-2 $\mathrm{km}$ between the Late Jurassic and the Early Cretaceous. From late Early/Late Cretaceous onwards, rocks present along the transect were exhumed to their present-day position."
\end{abstract}

* The abstract and parts of the chapter are published in the African Journal of Earth Sciences: R.Charton, G.Bertotti, A.Arantegui, and L.Bulot, 2018. The Sidi Ifni transect across the rifted margin of Morocco (Central Atlantic): Vertical movements constrained by LTT. 


\subsection{Introduction}

In the Atlantic realm, the link between the generally exhuming onshore and subsiding offshore domains is rarely investigated. At the same time, "km-scale" syn- and post-rift vertical movements are currently being documented in nearly all Atlantic passive margins. The proposed numerical models (e.g. Yamato et al., 2013) for the evolution of passive margin are fairly general and still unable to provide predictions by which they can be tested against observations from natural systems. This is partly due to the fact that most of these enigmatic vertical movements are documented onshore using LowTemperature Thermochronology (LTT), without any attempt to link them to the movements in offshore areas. These observations require an integrated analysis of the entire system from the exhuming domain (source) to the subsiding region (sink) to fully understand the tectonics involved.

In this chapter, we construct a $50 \mathrm{~km}$ long transect across the Moroccan rifted margin (fig. 2.1) from the western Anti-Atlas to the offshore passive margin basin, that we call the Sidi Ifni transect. The coexistence of Mesozoic sediments and regional unconformities in the study area (fig. 2.2) makes it a key transition between the generally subsiding offshore and exhuming Anti-Atlas (e.g. Gouiza et al., 2017a). Expanding on an existing LTT data base and using new and robust stratigraphic ages of the Mesozoic sediments, we present a reconstruction of syn- and post-rift vertical movements along the Sidi Ifni transect.

\subsection{Present-day architecture of the Sidi Ifni transect}

The Sidi Ifni transect (figs. 2.1 and 2.3) is composed of the Sidi Ifni dome in the onshore domain and the Atlantic continental shelf, slope, and abyssal basin in the offshore domain.

The Precambrian basement is composed of Neoproterozoic granites and metamorphic rocks (Pan-African orogeny; e.g. Thomas et al., 2004). These rocks are partially covered by autochthonous Late Neoproterozoic and Palaeozoic sediments (e.g. Michard et al., 2008), and were deformed during the late Palaeozoic Variscan orogeny (e.g. Burkhard et al., 2006). The pre-Mesozoic basement outcropping onshore is affected offshore by NW and SE dipping normal faults, which bound syn-rift half grabens. 


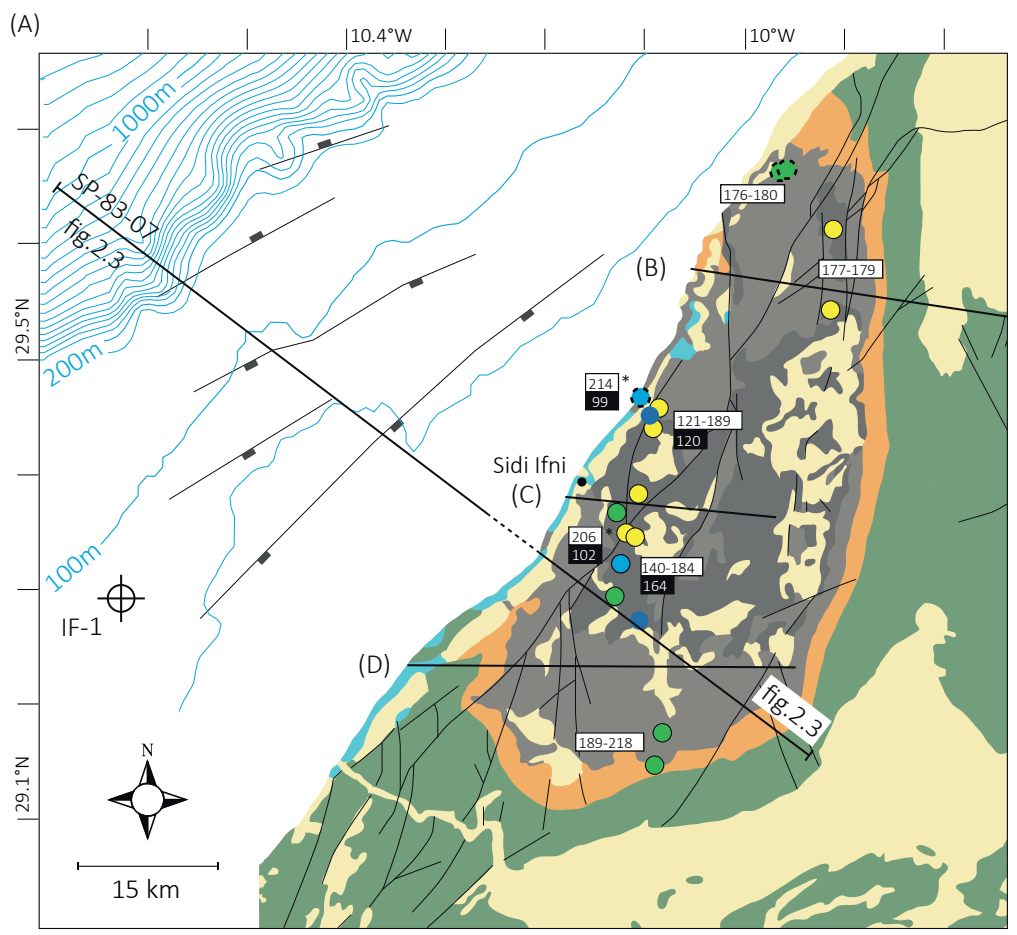

(B) WNW ESE
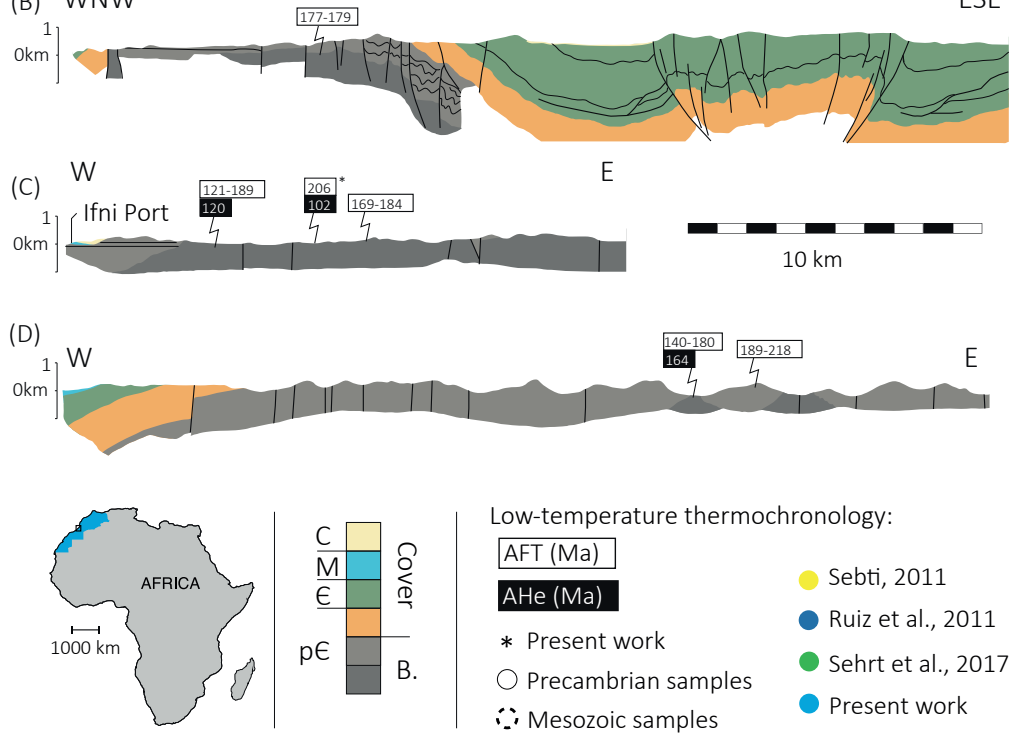

Figure 2.1. A) Simplified geological map of the Sidi Ifni area (after Hollard et al., 1985) and LTT data localisation (Sebti, 2011; Ruiz et al., 2011; Sehrt et al., 2017; present study). Bathymetry contour lines are every $50 \mathrm{~m}$. Syn-rift offshore normal faults are from Le Roy and Piqué (2001). C: Cenozoic; M: Mesozoic; 6 : Cambrian; $p \in$ : Precambrian; AFT: Apatite fission track ages; AHe: (U-Th)/He dating on apatites. B-D) Geological cross-section of the Sidi Ifni area (after Yazidi et al., 1986; 1991) onto which we projected LTT ages. 


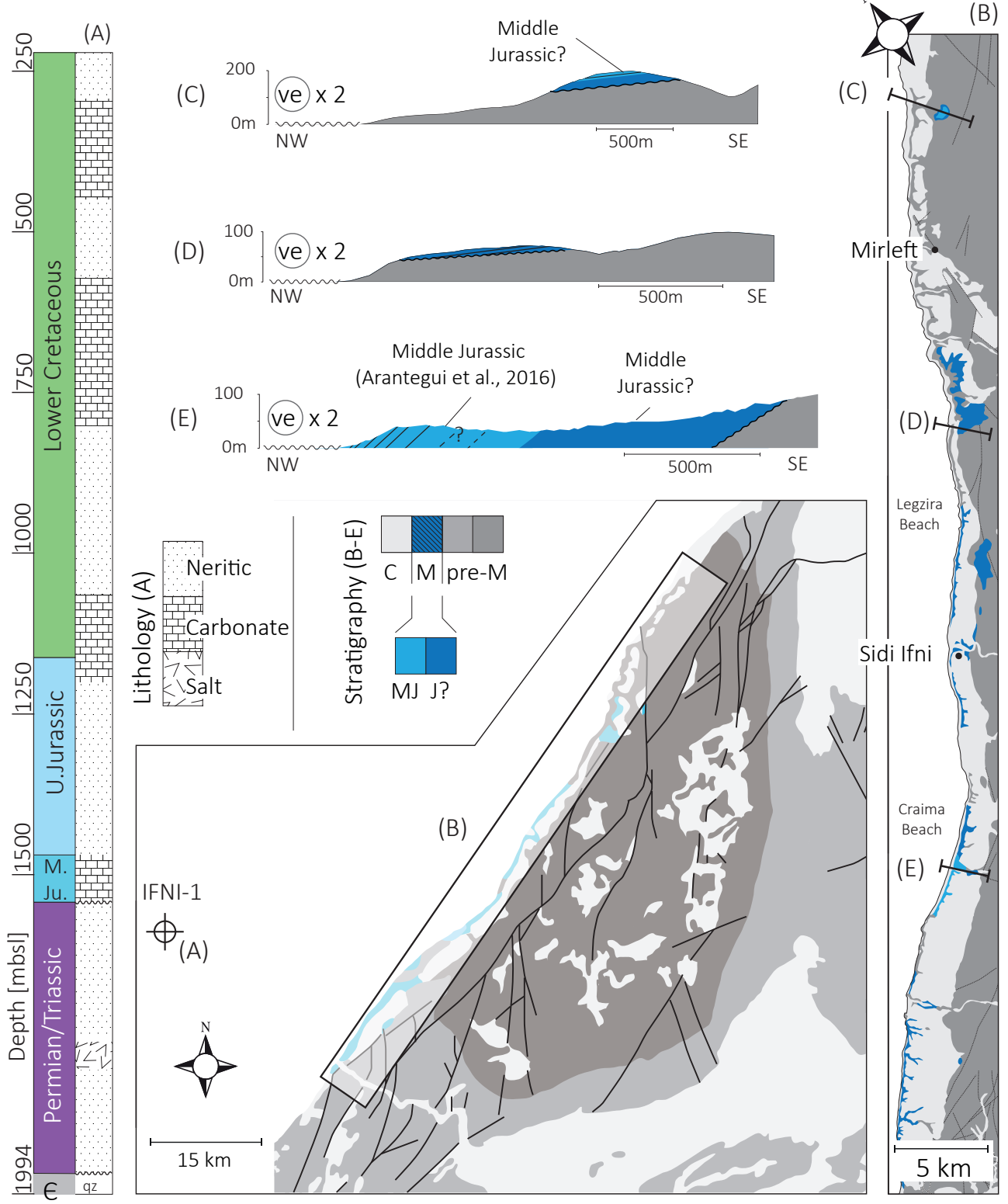

Figure 2.2. A) Stratigraphic log of the Ifni-1 (IF-1) well (after well report). Neritic: Neritic clastics and sandstones (continental for the Triassic), Carbonate: Limestones/dolomites, Salt: Salt and other evaporites. B) Simplified geological map of the Sidi Ifni Margin with highlight on Mesozoic sediments (after 1/100000 geological maps of Tiznit and Sidi Ifni; Yazidi et al., 1986; 1991). J?: Middle? Jurassic fluvial red conglomerates and red/pink/grey coarse to very coarse sandstones; MJ: Intertidal fine clastics and shallow marine carbonates identified as Middle Jurassic (Arantegui et al., 2016; Arantegui, 2018). C-E) Cross-sections illustrating the geometry of the contact between the Sidi Ifni basement rocks and the Mesozoic sediments (based on field work and Google Earth investigations). 
On the continental shelf, the Ifni- 1 well shows ca. $2 \mathrm{~km}$ thick Mesozoic sediments (fig. 2.2A), comprising the syn- and post-rift packages. The syn-rift Permian?-Triassic sediments are truncated by the Middle Jurassic sediments close to the shoreline. Westwards, Lower Jurassic platform sediments thin into basinal facies (Hafid et al, 2008), while they are also truncated near the coast by Middle Jurassic sediments, and are missing in Ifni-1 well (fig. 2.2). The well traversed the Middle Jurassic, which starts with a section of mixed carbonates and clastics.

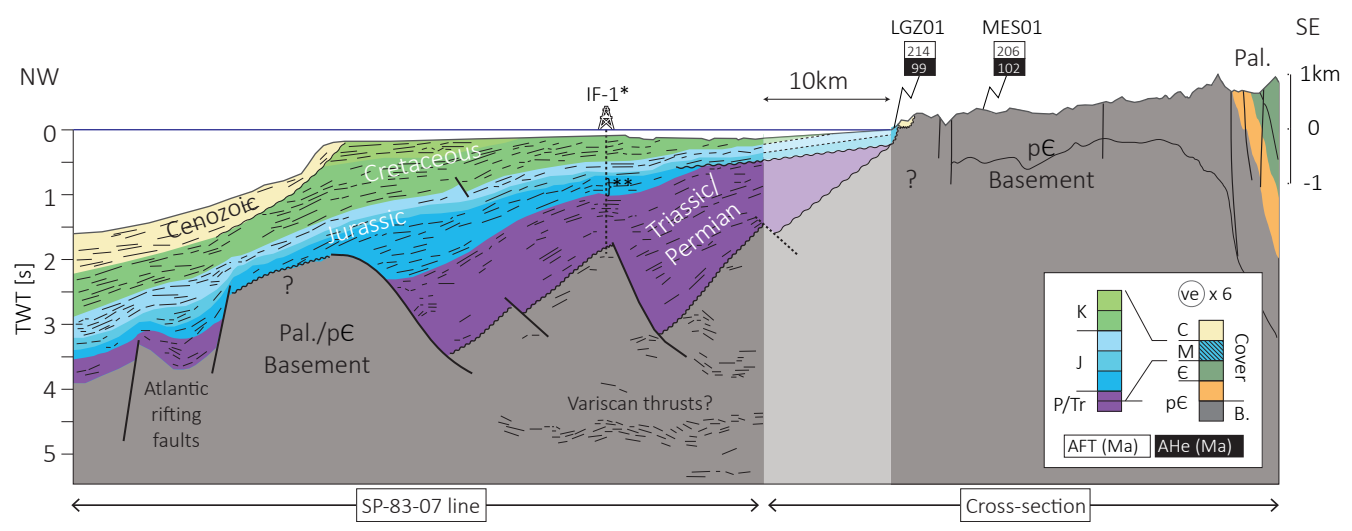

Figure 2.3. The Sidi Ifni transect: Composite cross-section running through the Sidi Ifni area, based on the interpretation of the 2D seismic line SP-83-07 from Gouiza (2011) and from the geological map from Hollard et al. (1985). The seismic line ends ca. $10 \mathrm{~km}$ before the shoreline. The gap (dashed line in figure 2.1A) was interpolated from the seismic interpretation and the geological map; the LTT ages are projected. *IF-1 is projected on the basement high at 2 second (TWT). ** The well report does not document Lower Jurassic sediments but only Triassic and Middle Jurassic. C: Cenozoic; M: Mesozoic (K: Cretaceous; J: Jurassic; Tr: Triassic); P: Permian; $\epsilon$ : Cambrian; $\boldsymbol{p} \in$ : Precambrian.

Mesozoic sediments in contact with Palaeozoic and Precambrian rocks are exposed along a narrow NE-SW oriented domain along the coastline (fig. 2.2B). Intertidal fine clastics and shallow marine carbonates exposed along Craima Beach were mapped by Yazidi et al. (1986) as Lower to Middle Cretaceous red sandstones with conglomerate interbeds, bituminous marls and limestones with Natica and Ampulina, overlying red conglomerates. The age was originally established on poorly preserved ostracods. These sediments have been re-dated using benthic foraminifera, green algae, gastropods and bivalves as Middle Jurassic (fig. 2.2E; Arantegui, 2018). In the north of the present study area, outcrops are mapped as Lower Cretaceous red conglomerates, sandstones and grey and pink argillaceous sandstones overlain by Middle Cretaceous dolomites, limestones and marly limestones with trigoniids, alectryonids and nerineids (Yazidi et al., 1991). The great resemblance in facies and fauna with the study area of Arantegui (2018) strongly suggests a generalized misdating of the Mesozoic outcrops in the Sidi Ifni area. Underlying undated sediments stratigraphically conformable are fluvial clastics (figs. 2.2C, D and E), and will be considered in this work as Middle Jurassic. Based on 
field observations, their architecture shows alluvial fans downlapping on basement rocks laterally associated to alluvial plain deposits.

Offshore, undifferentiated Upper Jurassic/Lower Cretaceous neritic clastics overly the Upper Jurassic carbonate platform, and are referred to as the 'Sables de Tan-Tan' Formation (e.g. Choubert et al., 1966; Martinis and Visintin, 1966). Finally, the Lower Cretaceous reflections in line SP-83-07 are interpreted as up-dip truncations close to the seabed in the continental shelf domain. The Cretaceous sediments drilled in Ifni- 1 are neritic clastics and carbonates. The Middle Cretaceous (Aptian-Albian) to Cenozoic sediments are only preserved close to the shelf edge and further offshore, while Late Cretaceous sediments are not recorded in the study areas.

\subsection{LTT and time-Temperature modelling: Methods and results}

The samples MESO1 and LGZO1 were collected from a granite of the Precambrian basement and the Middle Jurassic conglomerate of Lgezira beach, respectively (fig. 2.4). Apatite crystals within these samples were analysed for apatite fission tracks (AFT) and $(\mathrm{U}-\mathrm{Th}) / \mathrm{He}$ (AHe). The AFT measurements (table 2.1) were carried-out at Dalhousie University (Halifax, Canada) by B.Louis, and ages were calculated using the external Detector method (Gallagher et al., 1998). The method is described in Louis (2015). The AHe analyses (table 2.2) were conducted in Dalhousie University (Halifax, Canada) by R. Kislitsyn, based on K.Farley's technique summarized in Farley (2002).

The two samples produced Triassic AFT ages (206.1 \pm 10.3 and $214.3 \pm 8.8 \mathrm{Ma})$ and Cretaceous mean AHe ages (100.2 \pm 6.0 and $98.6 \pm 5.9 \mathrm{Ma})$. The abundance of confined tracks between 12-14 $\mu \mathrm{m}$ (fig. 2.4) is the results of long residence above the Apatite Partial Annealing Zone (APAZ; Bigot-Cormier, 2002) and is compatible with rapid cooling through the APAZ (e.g. Ghorbal et al., 2008). The dispersion of AHe single grain ages suggests a partial opening of the He system (Rougier et al., 2013) between ca. 170 and $60 \mathrm{Ma}$ for MESO1 and between 140 and 50 Ma for LGZ01. 

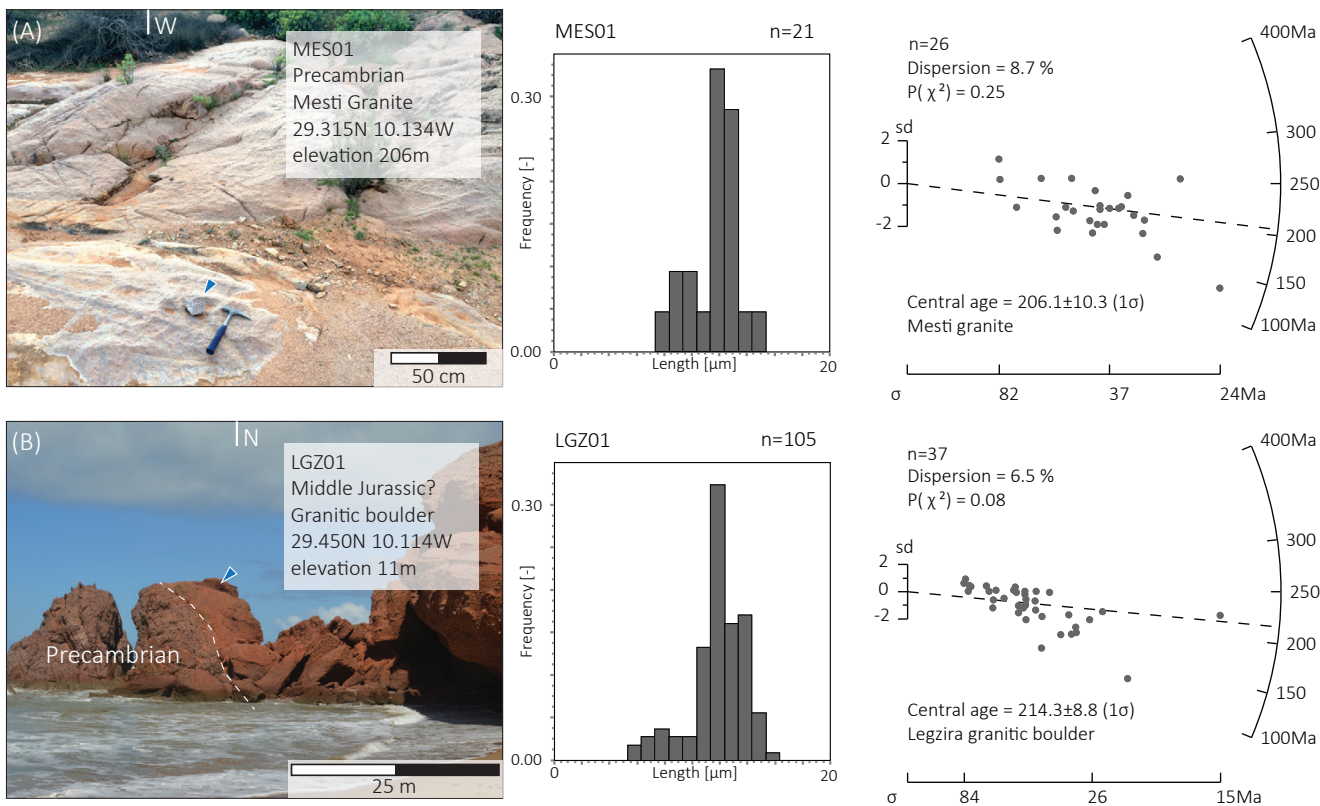

Dispersion $=6.5$

$P\left(X^{2}\right)=0.08$

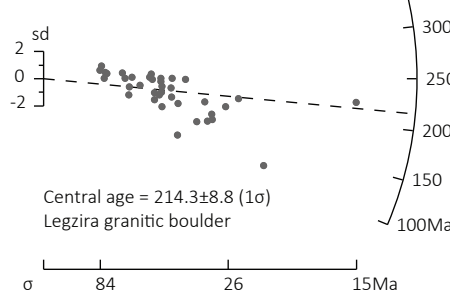

Figure 2.4. Sampled outcrops (left panel), track length distribution (central panel), and radial plots (bivariate scatterplots; right panel). Radial plots were made with RadialPlotter with Linear Transformation (Vermeesch, 2009). sd: Standard deviation; $\sigma$ : Error with $1 \sigma$ (Ma) (with precision given by 1/ $\sigma) ; \chi 2$ : Chi-square probability. A) Precambrian granite of the Sidi Ifni area exposed in a riverbed close to the city of Mesti, where MESO1 was sampled. B) Middle Jurassic red beds (or older; Arantegui, 2018) lying unconformably on the Proterozoic basement, located north of the Lgzira village, and where LGZO1 was sampled.

\begin{tabular}{|c|c|c|c|c|c|c|c|c|c|c|c|c|}
\hline Samples & $n$ & $\begin{array}{c}U \\
{[\mathrm{ppm}]}\end{array}$ & $\begin{array}{c}\rho_{\mathrm{s}}\left[\times 10^{5} \mathrm{tr} \mathrm{cm}^{-2}\right] \\
\left(\mathrm{n}_{\mathrm{s}}\right)\end{array}$ & $\begin{array}{c}\rho_{\mathrm{i}}\left[\times 10^{5} \mathrm{tr} \mathrm{cm}^{-2}\right] \\
\left(\mathrm{n}_{\mathrm{i}}\right)\end{array}$ & $\begin{array}{c}\rho_{\mathrm{d}}\left[\times 10^{5} \mathrm{tr} \mathrm{cm}^{-2}\right] \\
\left(\mathrm{n}_{\mathrm{d}}\right)\end{array}$ & $\begin{array}{l}P\left(x^{2}\right) \\
\%\end{array}$ & $\begin{array}{c}\text { AFT Ages } \pm 1 \sigma \\
{[\mathrm{Ma}]}\end{array}$ & $M T L \pm 1 \sigma[\mu \mathrm{m}]$ & $\begin{array}{r}\operatorname{Std}_{M T L} \\
{[\mu \mathrm{m}]}\end{array}$ & $n_{\mathrm{TL}}$ & $\begin{array}{l}\text { Dpar } \\
{[\mu \mathrm{m}]}\end{array}$ & $\begin{array}{r}\operatorname{Std}_{\text {par }} \\
{[\mu \mathrm{m}]}\end{array}$ \\
\hline MES 01 & 26 & 25.1 & $2.24(1430)$ & 2.19 (1399) & $11.4(6234)$ & 25.1 & $206.07 \pm 10.29$ & $11.38 \pm 0.85$ & 1.93 & 21 & 2.23 & 0.82 \\
\hline LGZ 01 & 36 & 32.9 & $2.933(2518)$ & $2.86(2455)$ & $11.8(6234)$ & 8.5 & $214.27 \pm 8.85$ & $11.77 \pm 0.31$ & 1.98 & 105 & 2.3 & 0.92 \\
\hline
\end{tabular}

Table 2.1. Apatite Fission track results. $n$ is the number of analyzed apatite crystals. $\rho_{s}$ is the density of spontaneous tracks, $\rho_{i}$ is the density of induced tracks, and $\rho_{d}$ is the density of fossil tracks. $n_{s}, n_{i}$, and $n_{d}$ are the number of tracks used for the density calculation. $P(\chi 2) \%$ is the Chisquare probability; samples pass the Chi-square test when $P>5 \%$. AFT ages are central ages with error $\pm 1 \sigma . M_{T L}$ is the mean track lengths with error $\pm 1 \sigma$ and standard deviation $S d t_{M T L} . n_{T L}$ is the number of measured track lengths. Dpar is the diameter of etched spontaneous tracks measured

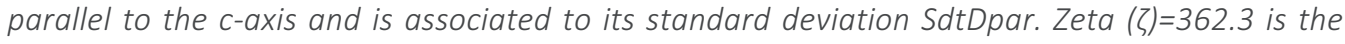
correcting factor defined by Fleischer and Hart (1972); $\sigma(\zeta)=8.6$ is the zeta uncertainty (Traditional calibration; Hurford, 1990). 


\begin{tabular}{|c|c|c|c|c|c|c|c|c|c|c|c|}
\hline Sample Aliquots & $\begin{array}{c}U \\
{[\mathrm{ppm}]}\end{array}$ & $\begin{array}{c}\text { Th } \\
{[\mathrm{ppm}]}\end{array}$ & $\begin{array}{c}147 \mathrm{Sm} \\
{[\mathrm{ppm}]}\end{array}$ & Th/U & $\begin{array}{c}\mathrm{eU} \\
{[\mathrm{ppm}]}\end{array}$ & $\begin{array}{c}\mathrm{He} \\
{[\mathrm{fmol}]}\end{array}$ & $\begin{array}{r}\text { Radius } \\
{[\mu \mathrm{m}]}\end{array}$ & $\begin{array}{r}\text { Mass } \\
{[\mu \mathrm{g}]}\end{array}$ & $\begin{array}{c}\text { Uncorrected } \\
\text { He age } \pm 1 \sigma[\mathrm{Ma}]\end{array}$ & Ft factor & $\begin{array}{c}\text { Corrected } \\
\text { He age } \pm 1 \sigma[\mathrm{Ma}]\end{array}$ \\
\hline MES01_I & 21.8 & 33.1 & 13.3 & 1.5 & 29.5 & 21.9 & 40.5 & 1.9 & $73.0 \pm 4.4$ & 0.65 & $113.0 \pm 6.8$ \\
\hline MES01_II & 18.9 & 29.0 & 9.5 & 1.5 & 25.6 & 30.8 & 54.0 & 4.5 & $48.5 \pm 2.9$ & 0.73 & $66.6 \pm 4.0$ \\
\hline MES01_III & 15.0 & 24.5 & 8.5 & 1.6 & 20.7 & 11.8 & 42.0 & 2.0 & $52.0 \pm 3.1$ & 0.65 & $79.7 \pm 4.8$ \\
\hline MES01_IV & 19.5 & 24.7 & 9.5 & 1.3 & 25.2 & 64.5 & 52.0 & 3.7 & $124.5 \pm 7.5$ & 0.72 & $172.6 \pm 10.4$ \\
\hline MES01_V & 21.1 & 34.1 & 12.6 & 1.6 & 29.0 & 6.8 & 35.0 & 1.0 & $40.8 \pm 2.5$ & 0.59 & $69.2 \pm 4.2$ \\
\hline MESO1 Mean & 20.0 & 31.5 & 11.0 & & & & 44.5 & & & & $100.2 \pm 6.0$ \\
\hline LGZ01_I & 24.2 & 27.1 & 27.4 & 1.1 & 30.6 & 25.5 & 44.0 & 2.6 & $58.9 \pm 3.5$ & 0.68 & $87.0 \pm 5.2$ \\
\hline LGZO1_II & 46.9 & 59.4 & 43.6 & 1.3 & 60.8 & 34.5 & 40.0 & 1.6 & $64.4 \pm 3.9$ & 0.64 & $100.7 \pm 6.0$ \\
\hline LGZ01_III & 32.5 & 55.6 & 30.7 & 1.7 & 45.4 & 74.2 & 45.5 & 3.1 & $96.0 \pm 5.8$ & 0.68 & $140.5 \pm 8.4$ \\
\hline LGZ01_IV & 24.8 & 27.0 & 24.5 & 1.1 & 31.1 & 85.2 & 57.0 & 5.9 & $84.8 \pm 5.1$ & 0.75 & $113.5 \pm 6.8$ \\
\hline LGZ01_V & 21.0 & 30.0 & 26.9 & 1.4 & 28.0 & 11.5 & 41.0 & 2.3 & $33.2 \pm 2$ & 0.65 & $51.1 \pm 3.1$ \\
\hline LGZO1 Mean & 29.9 & 39.8 & 30.6 & & & & 45.5 & & & & $98.6 \pm 5.9$ \\
\hline
\end{tabular}

Table 2.2. Result of apatite (U-Th)/He analyses. Five aliquots from each sample were analyzed. AHe ages are corrected using the Ft factor based on crystal geometries. eU: Effective uranium. Mean concentrations, radius, and ages are used as input in $t-T$ modelling.

The time-Temperature ( $\mathrm{t}-\mathrm{T}$ ) paths were obtained by modelling AFT lengths, Dpar, and AFT/AHe ages with the inverse modelling software HeFTy (Ketcham, 2005; table 2.3 and fig. 2.5). HeFTy runs a Monte Carlo algorithm that generates t-T paths that match to a certain extent (Goodness Of Fit, GOF) the input data. In the present study we use AFT models (composed of the AFT single-grain age data and the confined track lengths) and AHe models (composed of the mean AHe corrected age, the chemical composition, and radius of the apatite crystal). Paths are considered 'acceptable' when the GOF for the AFT model is between 5 and $50 \%$, and 'good' when higher than 50\%. The 'best fit' path has the highest GOF for both AHe and AFT models.

Five constraints were imposed to the different models. Constraint $a\left(300-260^{\circ} \mathrm{C} / 300-\right.$ $295 \mathrm{Ma}$ ) is based on the end of the Palaeozoic low-grade metamorphism documented by Ruiz et al. (2008) in the western Anti-Atlas (note that the authors described it from 330 to $300 \mathrm{Ma}$, which is on the edge of our modelling window). Constraint $\boldsymbol{b}$ (200-160 $\mathrm{Ma}$ ) is based on the Jurassic sediments lying on Palaeozoic and Precambrian rocks in the onshore Sidi Ifni area (Arantegui, 2018). Importantly, the constraint is set at surface temperature for the granitic boulder $\left(30-10^{\circ} \mathrm{C}\right)$, and close to surface temperatures for the sampled granitic $\left(60-20^{\circ} \mathrm{C}\right)$. We assume that the latter must have been protected from Jurassic erosion by the Precambrian (and Palaeozoic?) rock column sitting on top of it. The constraint $c\left(110-50^{\circ} \mathrm{C} / \mathrm{AHe}\right.$ age $\left.\pm 10 \mathrm{Myr}\right)$ is based on the produced AHe ages for its time component and the temperature range is based on the closure temperatures proposed by Shuster et al. (2006) for the AHe system. Constraint $d\left(30-10^{\circ} \mathrm{C} / 10-0 \mathrm{Ma}\right)$ is based on the fact that the samples were collected at the surface. Constraint $\boldsymbol{e}$ (300$10^{\circ} \mathrm{C} / 300-170 \mathrm{Ma}$ ) is based on the fact that, prior to deposition, we lack geological evidences of the source provenance. The large constraint $\boldsymbol{e}$ allows the realisations to be at surface as well as at buried temperatures before the deposition of the granitic boulder. 


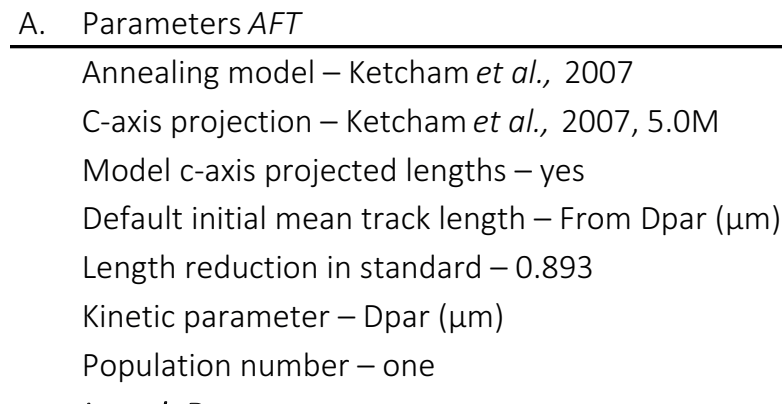

\section{Length Data}

Goodness of fit method - Kuiper's Statistic

\section{Age Data}

Uncertainty mode -1 SE $(\sigma)$

B. Parameters He Apatite

\section{Model parameters}

Calibration - Shuster et al., 2006 (Durango Apatite)

Stopping distances - Ketcham et al., 2011

Alpha calculation - Redistribution

\section{Data}

Age to report - Corrected

Age alpha correction - Ketcham et al., 2011

C. Inverse modeling

Search Method - Monte Carlo

Acceptable Path (GOF) - 0.05

Good Path (GOF) - 0.5

Subsegment spacing - Random

Ending condition - Path tried $=1000000$

\section{Segment parameters}

Path between constraints - Monotonic consistent

Halve - 2 times

Randomizer style - Episodic

No imposed maximum $\mathrm{dt} / \mathrm{dt}$

Table 2.3. Input parameters used for both simulations, which are performed with the HeFTy software (version 1.8.2; Apatite to Zircon; Ketcham, 2005). A) Parameters used for the AFT models. Cf irradiation, see Donelick and Miller (1991); Dpar is the diameter of etched spontaneous tracks measured parallel to the c-axis and is used as a proxy for the chemical composition of apatite and therefore for the annealing properties (Donelick et al., 1999); Kuiper's statistic, see Press et al. (1992); SE stands for standard error. B) Parameters used for the AHe models. C) Parameters used in the inverse modelling. 
(A) MESO1 - Mesti
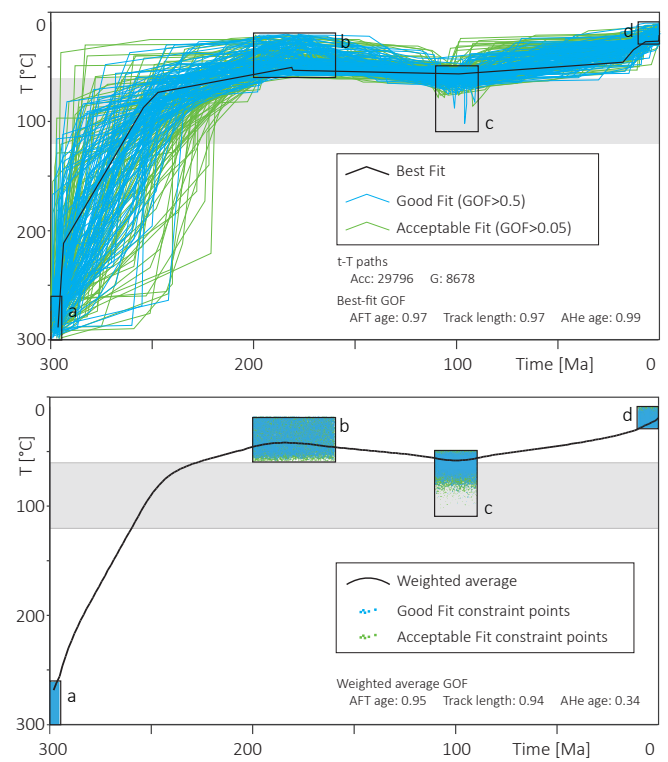

(B) LGZ01 - Lgezira

Granitic boulder
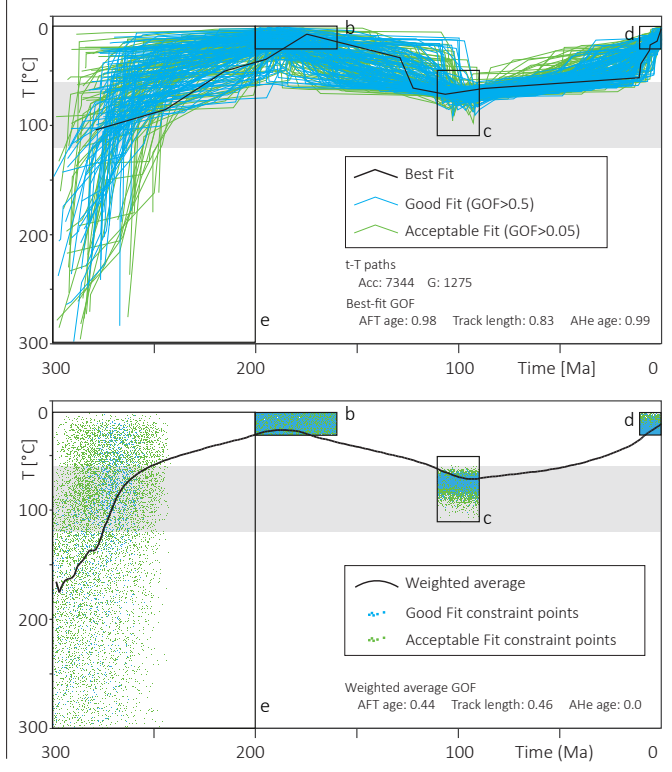

Constraints (user defined time/temperature windows)

APAZ

Figure 2.5. Results of $t-T$ modelling for A) MESO1 and B) LGZO1. Results are displayed with up to 200 curves for both good and acceptable goodness of fit (GOF) and the best-fit $t-T$ path (upper panels) or with the constraint points and the weighted average (lower panels). Forward modelling was used to reproduce the weighted average curves in order to obtain their GOF values. See modelling parameters in table 2.3. Acc: Acceptable paths; G: Good paths. APAZ: Apatite Partial Annealing Zone.

The thermal modelling results are characterised by two cooling events, of significantly different amplitudes, separated by a heating phase. The heating phase, although guided by constraint $c$, is supported by the generation of acceptable and good paths in both simulations. Results for both samples are very similar (fig. 2.5). The best-fit t-T path of MESO1 shows a cooling event ending in the Early/Middle Jurassic (cooling of $250 \pm 10^{\circ} \mathrm{C}$ between ca. 300 and $180 \mathrm{Ma}$ ), a subsequent heating to a temperature of ca. $50-60^{\circ} \mathrm{C}$ at the Early to Late Cretaceous boundary (heating of ca. $10^{\circ} \mathrm{C}$ between ca. 180 and 100 $\mathrm{Ma}$ ), followed by the second and last cooling episode (cooling of ca. $30 \pm 10^{\circ} \mathrm{C}$ between 100 and $0 \mathrm{Ma}$ ). The timing of heating and cooling episodes obtained from the granitic boulder is similar, but this sample reached a higher temperature (of ca. $70^{\circ} \mathrm{C}$ ) during the heating episode.

Between the two samples, the weighted averages are nearly identical, with a Permian to Early/Middle Jurassic cooling episode, Late Jurassic to Early Cretaceous heating episode, and Late Cretaceous to present-day cooling episode. However, the two samples are characterised by different temperature maxima and minima during each phase. At $170 \mathrm{Ma}$, temperatures are $20^{\circ} \mathrm{C}$ cooler in the boulder, while the boulder 
reached temperatures $\mathrm{ca} .10^{\circ} \mathrm{C}$ higher than the granite sample at $100 \mathrm{Ma}$. We used the forward modelling option of HeFTy in order to obtain the GOF of the weighted averages (fig. 2.5). While the AFT and AHe data of MESO1 are reproduced, the GOF value of the LGZO1 AHe age is 0 . When we increase the temperatures of ca. $10^{\circ} \mathrm{C}$ at $95 \mathrm{Ma}$, the forwarded paths yield GOF values significantly higher, especially with LGZO1, for which the AHe age GOF value reached 0.98 . We thereafter use the weighted average results to describe the evolution of the Sidi Ifni transect, with $10^{\circ} \mathrm{C}$ added at ca. $95 \mathrm{Ma}$ for LGZO1.

Previous LTT and t-T modelling studies carried-out in the Sidi Ifni area (figs. 2.2A and 2.6; Sebti et al., 2009; Sebti, 2011; Ruiz et al., 2011; Sehrt et al., 2017) concluded that a Carboniferous-Early Cretaceous $\mathrm{km}$-scale exhumation $(8-6 \mathrm{~km})$ was followed by a postrift subsidence $(1-2 \mathrm{~km})$ during the Late Cretaceous, and by an exhumation $(2-2.5 \mathrm{~km})$ during the Cenozoic. Our best-fit results show similar trend and amplitudes as the previous studies in the Sidi Ifni area (fig. 2.6 and references therein), with two cooling episodes separated by a heating event; the timing, however, is significantly different. The main reason lies in the age of the Mesozoic sediments used to constrain the curves, which were assumed to be Early Cretaceous but have now been shown to be Middle Jurassic (Arantegui, 2018). It is worth noting that three of the best-fit curves from Sebti (2011) also show the post-Variscan exhumation ending during the Jurassic. However, the related exhumation was interpreted as ending in the Early Cretaceous because of all the other modelled $\mathrm{t}-\mathrm{T}$ paths (see original models for good and acceptable realisations).

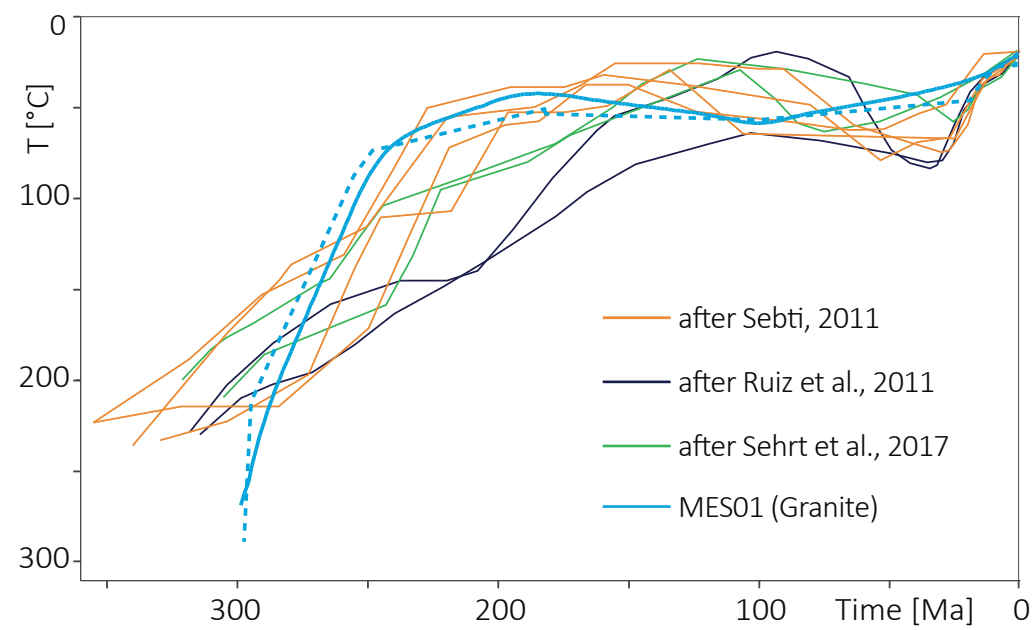

Figure 2.6. Best-fit (dashed) and weighted average t-T paths of MESO1 compared to the best-fit $t-T$ paths obtained in previous studies for samples of the Precambrian basement of the Sidi Ifni area. 


\subsection{Post-Variscan evolution of the Sidi Ifni transect}

Integrating results from LTT and t-T modelling with the backstripping of Ifni-1 well (Gouiza, 2011), we reconstructed the evolution of the Sidi Ifni transect (fig. 2.7). In this part, we convert the temperatures obtained from the weighted average curves to depths, using a geothermal gradient of $25^{\circ} \mathrm{C} / \mathrm{km}$ and a surface temperature of $20^{\circ} \mathrm{C}$; (e.g. Sehrt et al., 2017). Following the Variscan orogeny (fig. 2.7A), during the Permian, a major exhumation (ca. $7.5 \mathrm{~km}$ ) occurred in the (present-day) onshore domain. Although offshore Permian sediments are undifferentiated from the base of the syn-rift sediments, we consider the western part of the transect to have started subsiding during the Permian.

During the Triassic and Early/Middle Jurassic, the upward movement of the eastern part of the transect continued (ca. $1 \mathrm{~km}$, using the above-mentioned geotherm), persisting until ca. $180 \mathrm{Ma}$ (fig. 2.7B). The exhumation ended either 15-10 Myr after the continental breakup (Early Jurassic; ca. 195-190 Ma; Sahabi et al., 2004; Labails et al., 2010; Lundin and Doré, 2017) or 10-5 Myr before the continental breakup (Middle Jurassic; ca. 175-170; Klitgord et al., 1986; Davison, 2005; Gouiza et al., 2010), as the onset of drifting in the Central Atlantic is still debated. The related denudation event shed important volumes of sediments to the west, as attested by the sediments accommodated by the SE dipping normal faults (Le Roy and Piqué, 2001).

During the Middle Jurassic, erosion caused an unconformity which can be followed in the present day offshore domain above the Triassic and merges onshore with the unconformity above the Palaeozoic/Precambrian. We consider that the Early/Middle Jurassic exhumation episode in the western Anti-Atlas affected also the previously subsiding domain, reaching at least the vicinity of Ifni-1 well. Erosion affected the Palaeozoic series and the Sidi Ifni granite (fig. 2.7C), until the exhumation ended in the Early/Middle Jurassic. The sampled granitic boulder provenance may be the western Anti-Atlas, as both samples share a similar t-T evolution.

During the Late Jurassic to the Early Cretaceous (fig. 2.7D), important subsidence (between ca. 0.6 and $2 \mathrm{~km}$ ) occurred in the offshore and onshore domains. Related sediments are characterised by neritic clastics and carbonates (Ifni-1) and by a fluvial dominated environment (Sehrt et al., 2017). This event is recorded in the Ifni-1 well by an acceleration of the total subsidence rates, from ca. 0.02 to $0.03 \mathrm{~km} / \mathrm{Myr}$ (Gouiza, 2011). A concurrent subsidence episode is observed in the entire Anti-Atlas (Gouiza et al., 2017a). 
(E) Present Day [0 Ma]

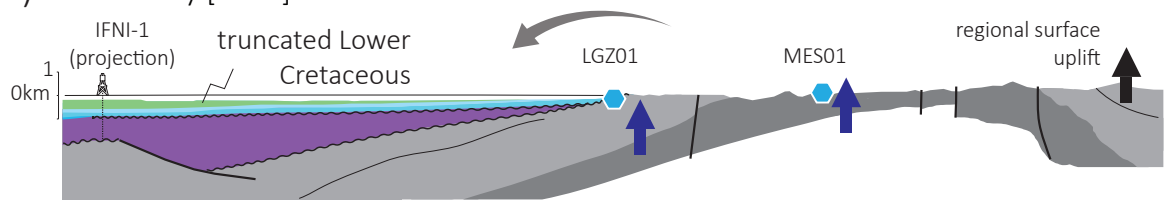

NW

(D) Early Cretaceous [145-120Ma]
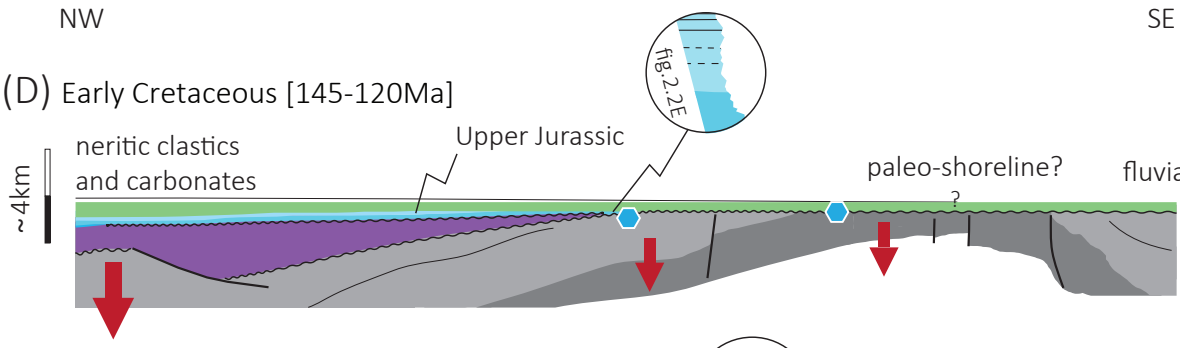

SE

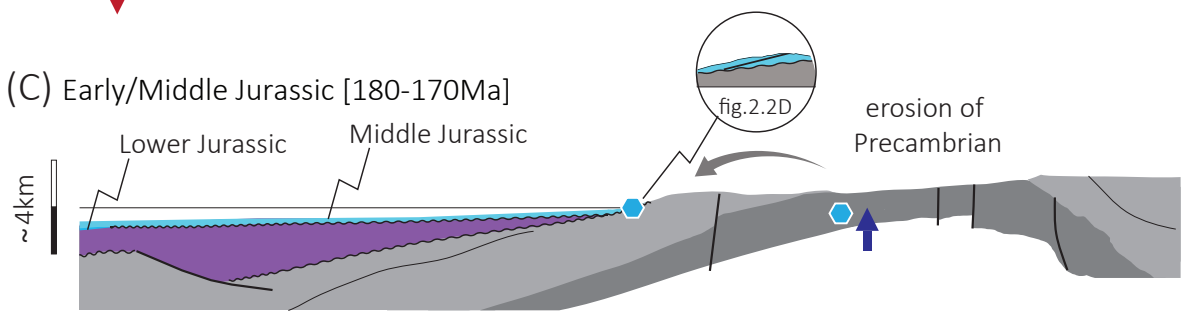

(B) Late Triassic [220-200Ma]

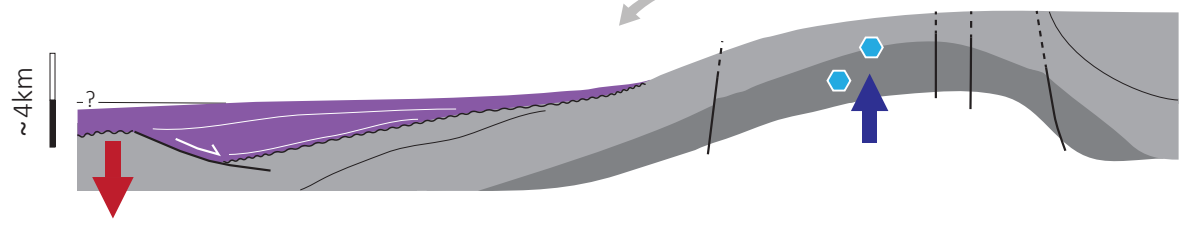

(A) Variscan [360-290Ma]
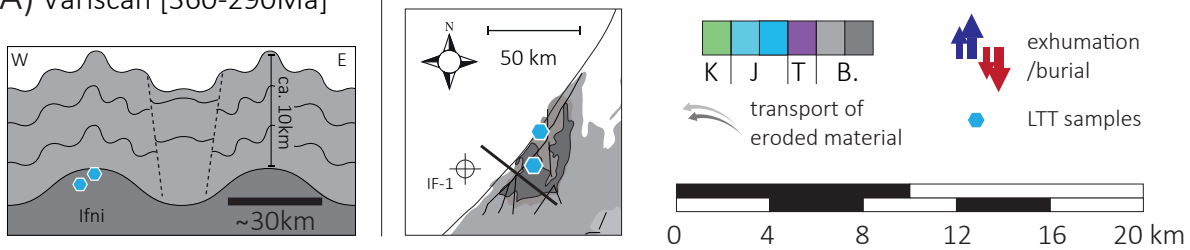

Figure 2.7. Conceptual model of the geological evolution of the Sidi Ifni transect; A) Situation at the end of the Variscan orogeny to E) present-day architecture of the Sidi Ifni margin simplified from figure 2.3. Vertical movements estimated from $t$ - $T$ modelling results of MESO1 and LGZO1 and backstripping of the Ifni-1 well (in Gouiza, 2011). The description of each stage is in the text. Horizontal scale is for B) to E) (no vertical exaggeration). B: Undifferentiated basement offshore and Precambrian/Palaeozoic basement onshore; $T$ : Triassic/Permian; J: Lower, Middle, and Upper Jurassic; K: Cretaceous. Thickness in the offshore domain is here estimated from Ifni-1 well, hence no Early Jurassic at the well position was considered. 
Subsidence ended between the Early and Late Cretaceous around $100 \mathrm{Ma}$ and was followed by exhumation from the Late Cretaceous onwards (between ca. 1 and $2 \mathrm{~km}$ ). The lack of Upper Cretaceous sediments in the Ifni- 1 well and up-dip truncations of the Lower Cretaceous reflections indicate that the Late Cretaceous to Cenozoic exhumation reached the present-day offshore domain (fig. 2.7E) and that Lower Cretaceous deposits reached farther east into the western Anti-Atlas.

The Cenozoic exhumation in the Sidi Ifni area is overall fairly gentle, with a slight acceleration in the last 10-20 Myr (fig. 2.5). The surface expression of the exhumation was investigated by Westaway et al. (2009). They recognised, with field reconnaissance and uplift modelling, that the presently exposed part of the transect has undergone over $200 \mathrm{~m}$ of uplift since the Pliocene. Several uplift phases are ascribed to the total motion, and have induced a general tilting of the landscape towards the offshore domain.

\subsection{Conclusions}

The $\mathrm{t}-\mathrm{T}$ modelling results constrained by Middle Jurassic stratigraphy preserved along the coast allowed the reconstruction of the geological evolution of the Sidi Ifni transect. Results indicate the exhumation of the onshore domain of the transect by ca. $7.5 \mathrm{~km}$ between the end of the Variscan orogeny and the Early/Middle Jurassic. Erosion affected the Palaeozoic series and eventually reached the Precambrian basement. Eroded material was routed to the subsiding Mesozoic basin to the northwest. Rocks along the transect were subsequently buried to a depth of 0.6 to $2 \mathrm{~km}$ during the Late Jurassic and the Early Cretaceous. The burial event is documented in the offshore well (IF-1) by an acceleration of the total subsidence rates. From the late Early/Late Cretaceous onwards, the onshore transect rocks were exhumed by 1 to $2 \mathrm{~km}$, while the Lower Cretaceous deposits in the continental shelf were exposed and eroded (truncated reflections). 
Acknowledgements: Helena van der Vegt is thanked for proofreading this chapter. Pierre-Olivier Bruna and Baptiste Lepillier are thanked for proofreading the figures and tables. Max Holicki is thanked for designing the Latex code used to nicely plot the t-T curves. Quinten Boersma is thanked for the geological discussions. 



\section{3}

\section{Post-Variscan evolution and thermal history of the Anti-Atlas}

Abstract: The Anti-Atlas belt of Morocco extends ENE-WSW, over more than $600 \mathrm{~km}$, from the Atlantic margin in the west to the interior of the African plate in the east. It exhibits Precambrian rocks outcropping as basement inliers and surrounded by marine Ediacaran-Cambrian sequences around the axis of the mountain range. The belt, which has for a long time been interpreted as of Variscan age, is now revealed to have experienced major vertical movements through Mesozoic and Cenozoic times. Thereby, the Anti-Atlas domain appears to be affected by two episodes of exhumation separated by an episode of subsidence. The initial episode occurred in the Late Triassic and led to the exhumation of 7.5-10.5 km of crustal rocks by the end of the Middle Jurassic (ca. 160-150 Ma). The following phase resulted in 1-3 km of basement subsidence and occurred during the Late Jurassic and most of the Early Cretaceous. The basement rocks were then slowly brought to the surface after experiencing 2-3.5 km of exhumation throughout the Late Cretaceous and the Cenozoic. The timing of these episodes of exhumation and subsidence coincides with major tectonic and thermal events in relation with the evolution of the Atlantic and Tethys Oceans, indicating that the effects of their rifting and drifting extended beyond their presumed margins.

* The abstract and parts of the chapter are published in the International Journal of Earth Sciences: M.Gouiza, R.Charton, G.Bertotti, P.Andriessen, and J.E.A.Storms, 2017. Post-Variscan evolution of the Anti-Atlas belt of Morocco constrained from low-temperature geochronology. 


\subsection{Introduction}

The Precambrian and Palaeozoic domains of the Anti-Atlas were recognised as relatively stable with no major post-Variscan vertical movements (Choubert and Marçais, 1952; Michard, 1976; Guiraud et al., 1987, 2005; Malusà et al., 2007; Michard et al., 2008). Various studies were conducted in the Anti-Atlas and its surroundings, using LowTemperature Thermochronology (LTT) and time-Temperature (t-T) modelling techniques (fig. 3.1 and references therein). A post-Variscan exhumation (in the sense of England and Molnar, 1990; i.e. an erosional unloading) and post-Early Cretaceous subsidence episodes are recognised and modelled in the western (Ruiz et al., 2011; Sebti, 2011; Sehrt, 2014) and central Anti-Atlas (Oukassou et al., 2013), but not in the eastern Anti-Atlas (Malusà et al., 2007).

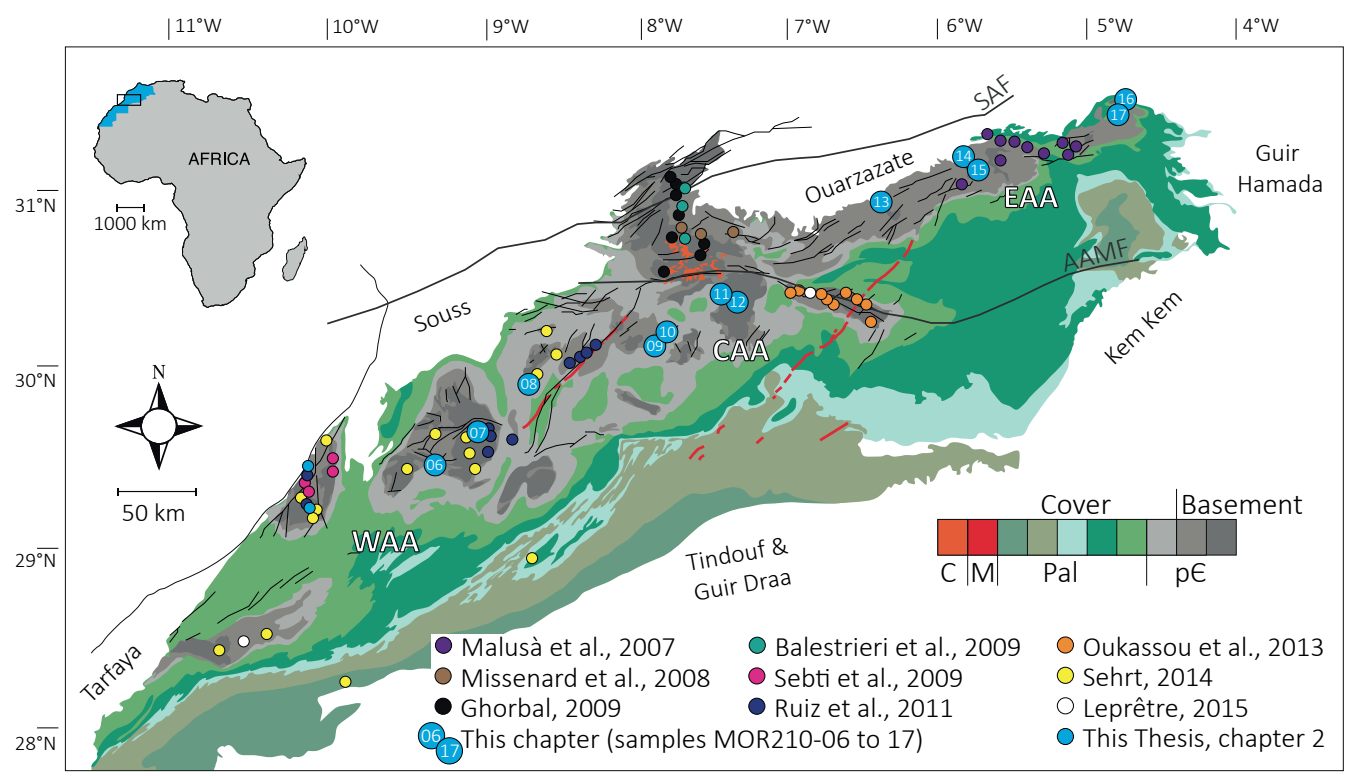

Figure 3.1. Geological map of the Anti-Atlas (modified and simplified from Hollard et al., 1985; Soulaimani et al., 2014) with LTT sample location with references therein. WAA, CAA, and EAA: Western, Central, and Eastern Anti-Atlas, respectively; C: Cenozoic (Siroua Volcanism; ca. 10-5 Ma); M: Mesozoic (CAMP related Dykes; ca. 200-195 Ma); Pal: Palaeozoic; $p \in$ : Precambrian.

Previous studies focused on one or several neighbouring basement outcrops (fig. 3.1), but none reconstructed the thermal history of the entire belt. The aim of this chapter is to unravel the thermal history of the Anti-Atlas from the end of the Palaeozoic to the present-day. 
Twelve samples from the Precambrian basement of the Anti-Atlas (fig. 3.1) were collected along a ca. $600 \mathrm{~km}$ long WSW/ENE transect (fig. 3.2A). Apatite Fission Tracks (AFT) and (U-Th)/He (AHe) ages were extracted, interpreted and used for t-T modelling with regional constraints.
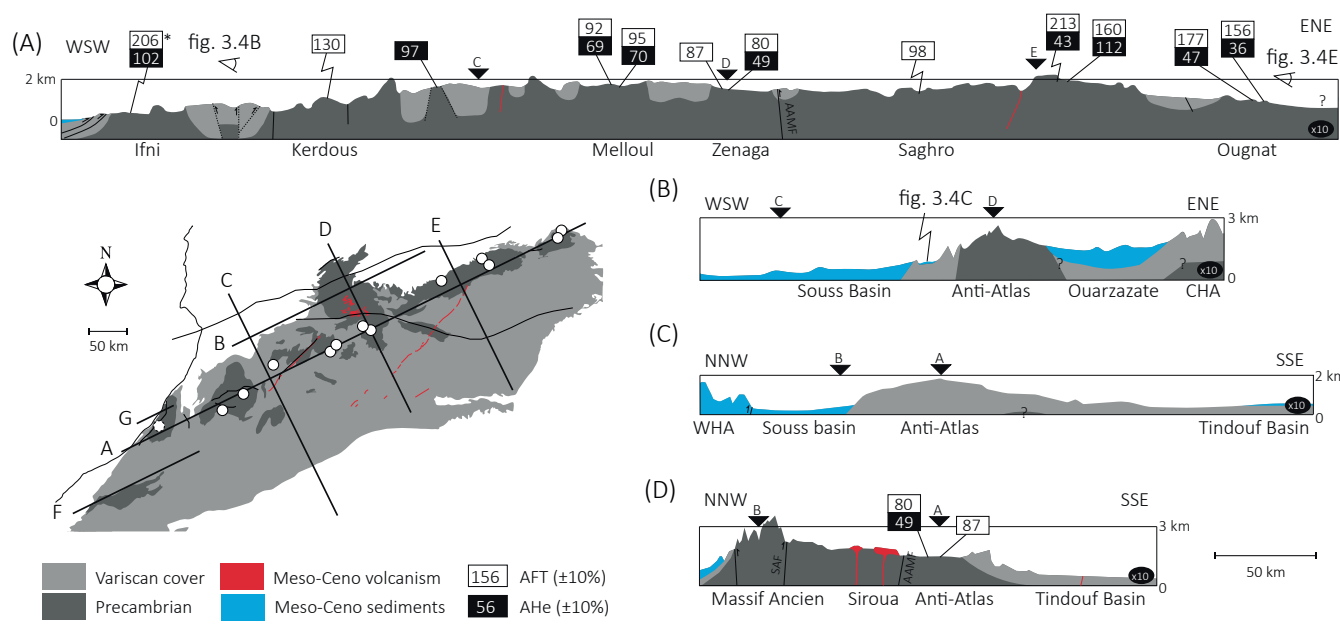

(B)

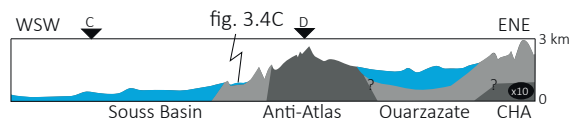

(C)

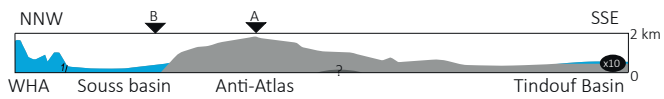

(D)

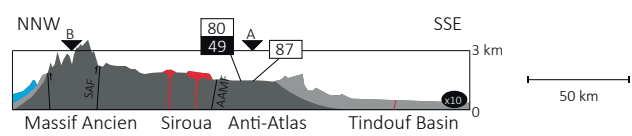

(E)

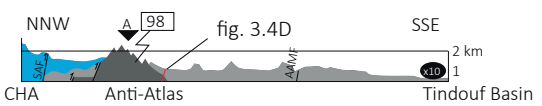

(F)

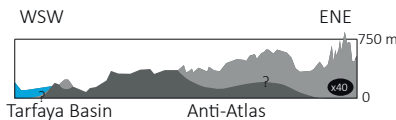

(G)

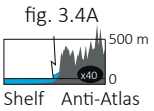

Figure 3.2. Geological cross-sections of the Anti-Atlas built from the geological map (including cross-sections; Hollard et al., 1985) and published cross-sections (see references thereafter). The position of the cross-sections and the LTT ages are shown on the map. Elevation profiles extracted from Google Earth; vertically exaggerated 10 times for $A$ to $E$ and 40 times for $F$ and $G$. Cross-sections $A, B, F$, and $G$ are parallel to the trend of the belt; Cross-sections $C, D$, and $E$ are perpendicular to the trend of the belt. A) Cross-section from the Ifni inlier to the Ougnat inlier (after Soulaimani et al., 2008; Raddi et al., 2007). * ${ }^{\text {LTT }}$ ages from chapter 2. B) Cross-section between the Souss and Ouarzazate basins; CHA: Central High Atlas. C) Cross-section along the western Anti-Atlas; WHA: Western High Atlas (after Soulaimani et al., 2008). D) Cross-section along the central Anti-Atlas (after Missenard et al. 2008; Balestrieri et al., 2009). E) Cross-section along the eastern Anti-Atlas (after Jossen and Filali Moutei, 1988; Robert-Charrue 2006; Malusà et al., 2007; Soulaimani et al., 2008; Raddi et al., 2007). F) Cross-section along Tarfaya Basin and Bas Braa (after Soulaimani et al., 2014). G) Cross-section along the Sidi Ifni continental shelf and the Ifni inlier (after Sebti, 2011). 


\subsection{Geological setting of the Anti-Atlas}

The Moroccan Anti-Atlas is located northwest of the Saharan domain. The WSW/ENE oriented belt extends over $700 \mathrm{~km}$ and has a mean elevation of $1500 \mathrm{~m}$ (figs. 3.1 and 3.2). It is bounded by the Triassic-Jurassic inverted rift of the High Atlas fold and thrust belt in the north, the Ougarta orogen in the east (in Algeria), and the Central Atlantic Ocean in the west. Surrounding low-lying and level high ground areas are the Souss and Ouarzazate basins separated by the Siroua Plateau in the north, the Palaeozoic unfolded succession of the Tindouf basin in the south, the Cretaceous-Neogene Hamada du Guir basin in the east, and the Meso-Cenozoic Tarfaya basin located on the south-western side (fig. 3.1). Topographically, we describe the Anti-Atlas as a bulge plunging to the south, south-west and north-east under piles of rather weakly deformed Upper Palaeozoic to Cenozoic sediments.

The basement of the belt (figs. 3.2 and 3.3) is composed of Precambrian metamorphosed rocks marked by the Neoproterozoic Pan-African orogeny (see Thomas et al., 2004 and Soulaimani et al., 2014 for the geological history of the Anti-Atlas). One tectonic feature remaining from this period is the Anti-Atlas Major Fault (AAMF; figs. 3.1 and 3.2). The ESE-WNW oriented AAMF is a Proterozoic sinistral strike-slip (Choubert and Faure-Muret, 1971; Ennih and Liégeois, 2001) and was interpreted as the relic of a Lower Neoproterozoic basin, which was thrusted during the Pan-African orogeny (Hefferan et al., 2000; Ennih and Liégeois, 2001). The AAMF subdivides the Precambrian of the belt into two distinct domains (Choubert and Faure-Muret, 1974). South of the AAMF, the basement consists of Eburnean Palaeoproterozoic schist and granitic intrusions and of Neoproterozoic shallow-water series, which were folded and metamorphosed during the Pan-African Orogeny (Walsh et al., 2002; Thomas et al., 2002; Gasquet et al., 2008; Soulaimani et al., 2014). North of the AAMF, the domain is mainly Neoproterozoic in age, with ophiolites and island arc-related gneiss and intrusions accreted during the climax of the Pan-African orogeny ( $D^{\prime}$ Lemos et al., 2006; El Hadi et al., 2010; Hefferan et al., 2014; Soulaimani et al., 2014).

The Anti-Atlas basement is covered by Late Neoproterozoic and Palaeozoic sediments (Fabre, 1988; Michard et al., 2008), deposited during and after the peneplanation of the Pan-African belt (e.g. Beuf et al., 1971; Fabre, 2005). The km-thick marine Palaeozoic sedimentation of the Anti-Atlas basin thins towards the east (e.g. Michard et al., 2008), as the sag basin is then connected to the Rheic ocean. From the Carboniferous to Early Permian, Gondwana converged towards Laurussia (Soulaimani et al., 2014 and references therein) and the subsequent Variscan orogenesis eventually led to the accretion of Pangaea. Folding and deformation of the Anti-Atlas occurred between the Late Carboniferous and the Early Permian (e.g. Bonhomme and Hassenforder, 1985; Michard et al., 2008). The Variscan tectonic in the entire Anti-Atlas is referred to as a thick-skinned basement inversion (Piqué et al., 1987; Helg et al., 2004; Burkard et al., 2006; Michard et al., 2010) with the exception of the westernmost Anti-Atlas, which is characterized by thin-skinned tectonic (fig. 3.2A; west of the Bas-Drâa and Ifni 
Precambrian outcrops, along the western margin; Hoepffner et al., 2005; Burkhard et al., 2006). The Variscan chain was peneplained prior to the Mesozoic (Variscan Unconformity; Frizon de Lamotte et al., 2013; Soulaimani et al., 2014). Several other unconformities are recognised in the surroundings basins within the Meso-Cenozoic sequences (fig. 3.3). Most of the Mesozoic sedimentary rocks are missing in the AntiAtlas (figs. 3.1, 3.2, and 3.3). However, a significant amount of poorly dated infraCenomanian (e.g. Choubert et al., 1966) fluvial sediments are exposed around the western Anti-Atlas (figs. 3.4A and C).

During the Triassic, the Anti-Atlas was located east of the NE-SW oriented Central Atlantic rift and south of the ENE-WSW oriented High Atlas rift (Sahabi et al., 2004; Michard et al., 2008). The troughs were filled with rift-related sediments, recognised around the Anti-Atlas in the subsurface of the north Tarfaya (e.g. El Amra-1 well; Olsen, 1997; Michard et al., 2008) and Souss (e.g. EGA-1 well; Frizon de Lamotte et al., 2000; Sebrier et al., 2006) basins, as well as in outcrops north of the Siroua Massif (Chevalier et al., 2001; El Arabi et al., 2003 and references therein). The Central Atlantic Magmatic Province (CAMP; ca. 200-195 Ma) sills and SW-NE oriented dykes are exposed in the mountainous and central part of the belt (fig. 3.4D; e.g. Sebai et al., 1991; Marzoli et al., 1999; Knight et al., 2004).

The onset of drifting in the Central Atlantic, between 190 and $170 \mathrm{Ma}$ (debated, see review in Michard et al., 2008; Labails et al., 2010), marked the separation between North America and North-West Africa. After the CAMP event, the extension in the High Atlas rift basin stopped, resulting in an aborted rift (e.g. Michard et al., 2008). From the Bathonian to the Early Cretaceous, northern Morocco witnesses the denudation of the so-called West Moroccan Arch (e.g. Choubert and Faure-Muret, 1971; Ghorbal et al., 2008; Frizon de Lamotte et al., 2009), to which the Anti-Atlas was supposedly attached. The Upper Jurassic and Lower Cretaceous siliciclastic sediments deposited in the Atlantic basins (e.g. Jenny et al., 1981; Ranke et al., 1982; Abou Ali et al., 2004; Davison, 2005; Hafid et al., 2008; Haddoumi et al., 2008; Wenke, 2014) are likely, at least partially, sourced from this 'arch' (Ghorbal et al., 2008). In the eastern Central Atlantic margins, the Late Cretaceous starts with a major transgression that lasted from the Cenomanian to the Turonian (e.g. Schlanger and Jenkyns, 1976; Haq et al., 1987). Some authors assume that the inundation reached the Anti-Atlas (fig. 3.4E; e.g. Ghorbal et al., 2008; Ruiz et al., 2011; Sehrt, 2014) and perhaps covered it completely (Frizon de Lamotte et al., 2009; Guimerà et al., 2011).

Early studies conducted in the Tarfaya basin (Martinis and Visintin, 1966; Choubert et al., 1966) observed that the Cretaceous sequences were not tectonically deformed, but display a gentle dip towards the Atlantic Ocean. Albian fossils were found above the "Sables de Tan-Tan" Formation, which is composed of 1-4 km of undifferentiated clastics. 
(A)

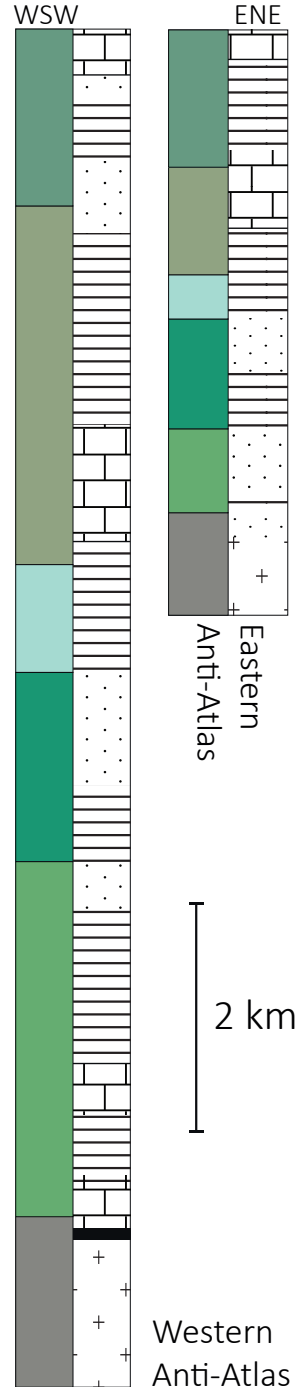

(B)

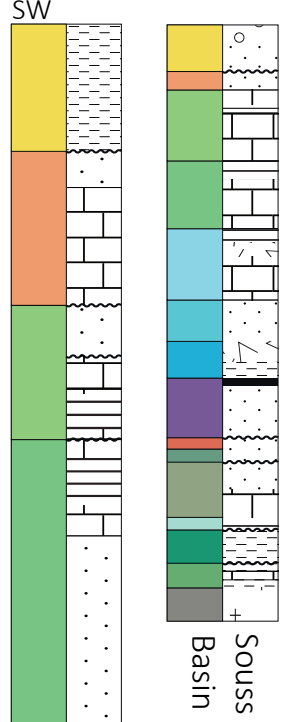

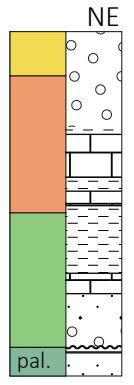

网

ఝ్ర

$\stackrel{n}{\Xi}$
(C)

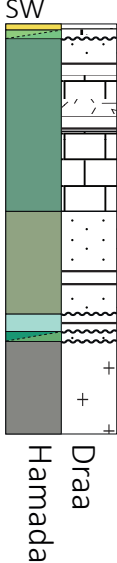

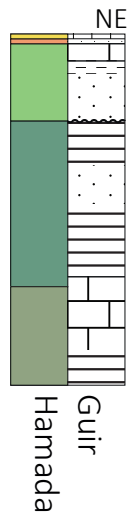

ن
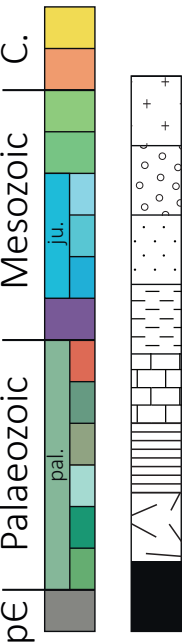

Crystalline rocks

Conglomerates

Sandstones/siltstone

Pelites/redbeds

Limestone/dolomite

Marls/mudstones

Evaporites

Volcanics

Figure 3.3. Simplified stratigraphic columns and dominant lithologies of the different regions of the Anti-Atlas and surrounding the belt, modified from the following studies. A) Anti-Atlas after Michard et al. (2008). B) Tarfaya basin after Ranke et al. (1982); Souss basin after Samaka and Bouhaddioui (2003); Ouarzazate basin after Ellero et al. (2012). C) Draa Hamada after Leprêtre et al. (2015) and Guerrak (1989); Guir Hamada after El Youssi (1993) and Robert-Charrue and Burkhard (2008).

The thickest interval of this formation were traversed onshore by exploration wells at the western edge of basin and were attributed to the Early Cretaceous. The limit between the Tarfaya basin and the Anti-Atlas is described as a tectonic one (Martinis and Visintin, 1966). 

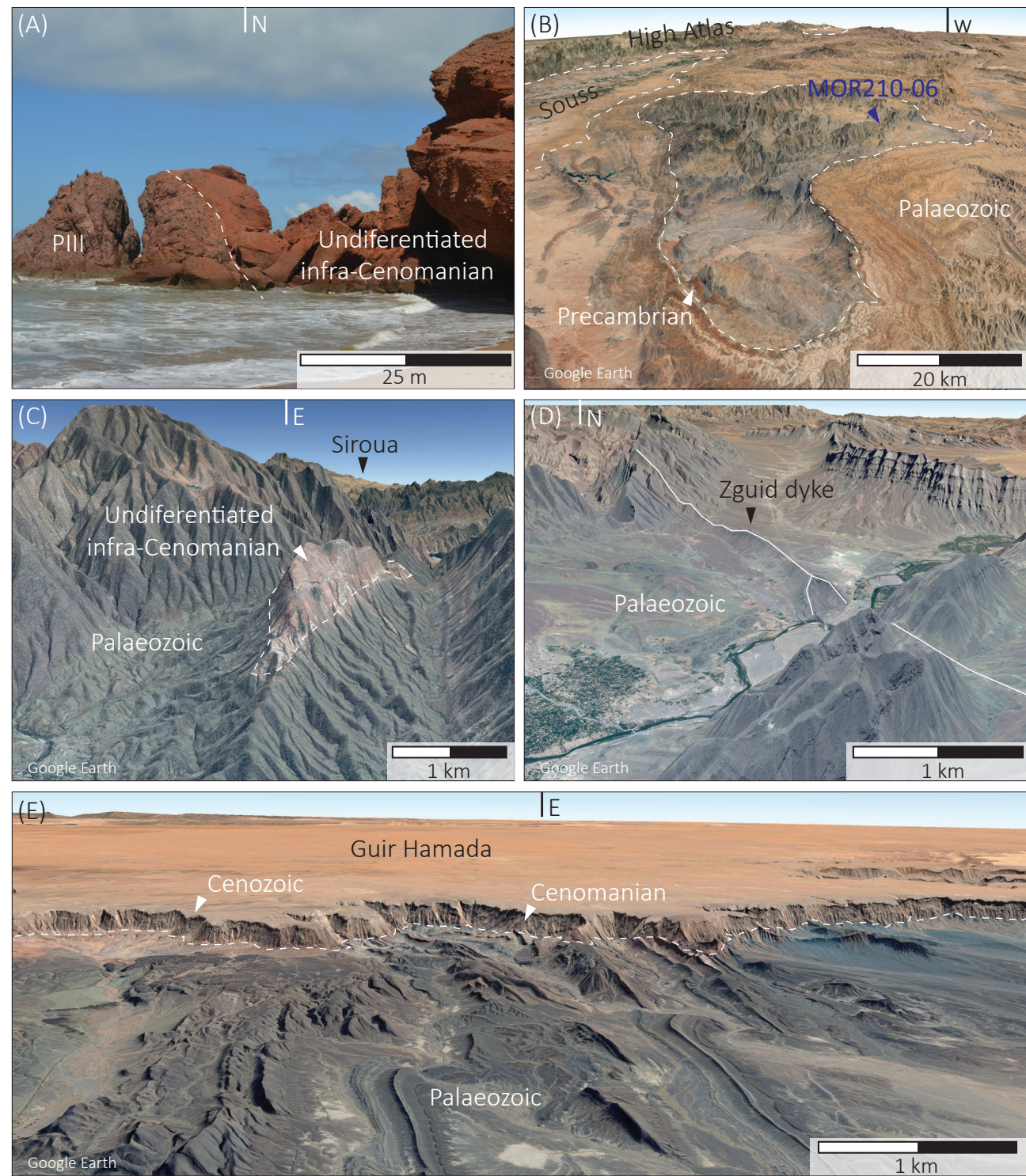

Figure 3.4. A) Undifferentiated infra-Cenomanian (Yazidi et al., 1991) lying with unconformity on the Precambrian basement (PIII: Proterozoic), located north of the Lgezira village (see the previous chapter for re-dating of these redbeds to the Jurassic) B) Precambrian outcrops of the Anti-Atlas (Kerdous inlier) in which MOR210-06 was sampled. C) Undifferentiated clastic infra-Cenomanian overlying the Variscan Palaeozoic sediments. D) CAMP Zguid dyke, south of the Saghro Precambrian dome (or inlier), crosscutting a syncline of the Anti-Atlas Palaeozoic. E) Eastern termination of the belt, plunging under the Cenomanian to Cenozoic Guir Hamada. B-E) Google Earth scenes with vertical exaggeration of 3 (positions on cross-sections in figure 3.2). 
In North-West Africa, the Late Cretaceous and Cenozoic are marked by the Alpine/Atlasic orogenies. The convergence between the African and European plates started in the Late Cretaceous, resulting from the South Atlantic opening (Piqué et al., 2002; Rosenbaum et al., 2002 and references therein). Collision and related deformations occurred in the Eocene, and are still on-going (reviewed in Michard et al., 2008 and Frizon de Lamotte et al., 2009).

Inherited faults from the Late Neoproterozoic were reactivated during the Cenozoic horizontal shortening event (Soulaimani et al., 2014 and references therein) as they involve Palaeozoic, Mesozoic, and Cenozoic rocks (Choubert, 1952). The most striking result of the Alpine collision in Morocco is the High Atlas rift inversion, culminating at $4167 \mathrm{~m}$ (Toubkal Massif). In the Anti-Atlas, deformation is considered to be mild with long wavelength crustal folding (Choubert and Marçais, 1952; Hoepffner et al., 2005; Frizon de Lamotte et al., 2000; Helg et al., 2004; Guimerà et al., 2011).

\subsection{LTT method and results}

As revealed by figure 3.1, sampling from previous works is covering the mountainous domain from west to east. Despite the extensive amount of studies, LTT data is lacking for an important surface of the belt. The samples (table 3.1) and their locations were targeted for their apatite crystal content, i.e. targeting the crystalline basement (figs. 3.4 and $3.5 B$ ).

Fission tracks and (U-Th)/He dating methods, with apatites and zircons, are applicable together for the investigation of the cooling of rocks between ca. 40 and $250^{\circ} \mathrm{C}$. This range is likely matching the temperature window of the Anti-Atlas thermal history from the Variscan to the present day, because the Palaeozoic cover is of low-grade metamorphism (i.e. $<300^{\circ} \mathrm{C}$; e.g. Ruiz et al., 2008).

\subsubsection{Analytical methods}

The samples were processed at the mineral separation laboratory of the VU University of Amsterdam. Samples were crushed, and minerals were sieved to conserve only the apatite fraction size and sorted according to their density. For the AFT analyses, the apatites obtained from the separation were polished, irradiated, and etched in acid, enabling fission tracks to be measured under a microscope. For the AHe analyses, two to four apatites were manually selected from each sample in a two-step process that involves Helium extraction and mass spectrometer measurements. The samples were processed and analysed for AFT and (U-Th)/He. The mineral separation, AFT, and AHe methods are detailed in the following paragraphs. 


\begin{tabular}{|c|c|c|c|c|c|c|c|c|}
\hline Anti-Atlas & Samples & Latitude [Dec.] & Longitude [Dec.] & Elevation [m] & AFT age & [Ma] & AHe ag & e [Ma] \\
\hline \multirow{3}{*}{ Western } & MOR210-06 & 29.58162 & -9.17497 & 1090 & 135.2 & \pm 7.7 & 109.8 & \pm 10.7 \\
\hline & MOR210-07 & 29.70680 & -8.96750 & 1045 & 129.5 & \pm 9.8 & & - \\
\hline & MOR210-08 & 30.02728 & -8.59041 & 1807 & & & 96.8 & \pm 9.6 \\
\hline \multirow{5}{*}{ Central } & MOR210-09 & 30.19866 & -7.80825 & 1822 & 92.2 & \pm 3.9 & 69.0 & \pm 6.6 \\
\hline & MOR210-10 & 30.28485 & -7.79115 & 1780 & 94.7 & \pm 4.1 & 69.7 & \pm 6.7 \\
\hline & MOR210-11 & 30.47779 & -7.37185 & 1568 & 79.9 & \pm 7.7 & 49.3 & \pm 4.8 \\
\hline & MOR210-12 & 30.45819 & -7.35064 & 1550 & 87.5 & \pm 3.9 & & - \\
\hline & MOR210-13 & 31.01398 & -6.43273 & 1284 & 98.1 & \pm 5.3 & & 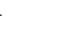 \\
\hline \multirow{4}{*}{ Eastern } & MOR210-14 & 31.22250 & -5.76013 & 1831 & 213.3 & \pm 16 & 42.7 & \pm 4.1 \\
\hline & MOR210-15 & 31.19869 & -5.75257 & 1987 & 160.3 & \pm 6.5 & 112.0 & \pm 10.8 \\
\hline & MOR210-16 & 31.57646 & -4.77030 & 941 & 156 & \pm 6.9 & 35.8 & \pm 3.4 \\
\hline & MOR210-17 & 31.52191 & -4.77644 & 974 & 177 & \pm 10.7 & 47.1 & \pm 4.6 \\
\hline
\end{tabular}

Table 3.1. Location, description, and LTT results (AFT: Apatite fission tracks; AHe: (U-Th)/He dating on apatite) of the collected samples.

In order to extract apatite grains, the rock samples were split into small pieces using a large hydraulic rocksplitter. The pieces were then crushed in a jaw-crusher, then in a disk mill. The crushed samples were sieved in a sieve machine to separate the fraction smaller than $250 \mu \mathrm{m}$, which is deslimed in a wet sieve system to remove everything that is less than $32 \mu \mathrm{m}$ and dried in the oven at $50^{\circ} \mathrm{C}$. The obtained $250-32 \mu \mathrm{m}$ powder was further processed by heavy liquid and overflow centrifuge to separate the minerals based on their densities. Since the average apatite density is around $3.19 \mathrm{~g} / \mathrm{cm}^{3}$, grains with densities lower than 3.12 and higher than $3.33 \mathrm{~g} / \mathrm{cm}^{3}$ were separated from the rest. Finally, the latter fraction $\left(3.12<\rho<3.33 \mathrm{~g} / \mathrm{cm}^{3}\right)$ went through a Frantz magnet to separate magnetisable and non-magnetisable minerals. At this stage, the nonmagnetisable fraction contains mostly apatites.

Apatite crystals were mounted in epoxy along with six zircon minerals aligned along a diagonal. The mounts were grinded and polished to reveal the internal surface of the apatites and then exposed to $5.5 \mathrm{M} \mathrm{NHO}^{3}$ for 20 seconds at room temperature to reveal fission tracks caused by the spontaneous fission of ${ }^{238} \mathrm{U}$. The external detector method was applied by placing low $U$ micas on top of the apatite mounts, and the samples were sent to the FRM II research reactor in Garching (Germany) for irradiation, along with dosimeter glasses, $\mathrm{CN}-5$, of known uranium content for the determination of the thermal neutron flux. After irradiation, the mica sheets were removed from the apatite mounts and the dosimeter glasses, and etched for $12 \mathrm{~min}$ and then $25 \mathrm{~min}$ in acid solution, $48 \% \mathrm{HF}$, at room temperature to make the induced tracks visible under an optical microscope. Fission track densities, lengths and Dpar were measured in apatite grains with internal surfaces parallel to the $C$-axis, using $1520 x$ magnification with a $100 x$ dry objective and the FTStage 4 upgrade program (Dumitru, 1993). Dpar, which represents the long axes of FT etch-pits, is a rough proxy for the chemical composition of apatite and therefore for the annealing properties (Donelick et al., 1999). Since the

* Samples were collected and analysed by Mohamed Gouiza. 
${ }^{235} \mathrm{U} /{ }^{238} \mathrm{U}$ ratio is constant, the number of induced tracks is proportional to the concentration of ${ }^{235} \mathrm{U}$ in the apatites and applied thermal neutron flux. The confined track lengths were measured in every sample for their important insights in thermal history (Laslett et al., 1982; Gleadow et al., 1986; Green et al., 1986; Barbarand et al., 2003; Tello et al., 2006). Fish canyon tuff and Durango apatites were used as age standards to determine the Zeta factor (Hurford and Green, 1983) of our apatites, from which finally, pooled AFT ages were calculated. Following the method described in Gallagher et al. (1998), fission track ages have been calculated with the TRACKKEY software (Dunkl, 2002), using a zeta value of $358 \pm 10$ for apatite and CN-5 glass.

Two to four apatites crystal (aliquots) of each sample were hand-picked to obtain the best suitable aliquots to be dated. (U/Th)He dating was accomplished at the noble gas laboratory of the VU University of Amsterdam, through a two-step process that involves Helium extraction and the determination of $U$ and Th concentrations using ICP-MS technique. First, each single apatite crystal went through a Helium extraction line equipped with a laser and mass spectrometer. The apatite crystal is heated by laser up to $950^{\circ} \mathrm{C}$ to release the $\mathrm{He}$, which was then expanded into the mass spectrometer, where He abundance was measured as counts per second and converted to ccSTP using an internal standard. After He extraction, the apatite crystal was unloaded and cleaned in a $7 \mathrm{ml}$ Teflon beaker filled with MilliQ water. The sample was spiked with calibrated ${ }^{229} \mathrm{Th}^{233} \mathrm{U}$ solution $\left({ }^{233} \mathrm{U} /{ }^{229} \mathrm{Th}=0.96\right)$ and dissolved by adding ten drops of $\mathrm{HNO}$ and ten drops of concentrated HF. The beaker was placed on a hotplate at $120^{\circ} \mathrm{C}$ for 48 hours. Finally, the solution was transferred to an ICP-MS tube for determination of the $\mathrm{U}$ and Th concentrations. The effective uranium concentration (eU; Shuster et al., 2006; Flowers et al., 2009), which has an influence on the He closure temperature, is calculated as:

$$
\mathrm{eU}=[\mathrm{U}]+0.235 \times[\mathrm{Th}]
$$

\subsubsection{LTT results}

The AFT ages are between $213.3 \pm 16$ and $79.9 \pm 7.7 \mathrm{Ma}$ in the eastern and central AntiAtlas, respectively (table 3.2).

The produced ages are between ca. 80-100 Ma in the central Anti-Atlas (MOR210-09, 10, 11, 12, and 13), ca. 130-135 Ma in the western Anti-Atlas (MOR210-06 and 07), and ca. 150-210 Ma in the eastern Anti-Atlas (MOR210-14, 15, 16, and 17). AFT ages become younger towards the central Anti-Atlas (fig. 3.2A). 


\begin{tabular}{|c|c|c|c|c|c|c|c|c|c|c|c|c|c|c|c|c|}
\hline Samples & $n$ & $\begin{array}{l}\rho_{5}\left(\times 10^{5}\right) \\
{\left[\operatorname{tr} \mathrm{cm}^{-2}\right]}\end{array}$ & $\mathrm{n}_{\mathrm{s}}$ & $\begin{array}{l}\rho_{\mathrm{i}}\left(\times 10^{5}\right) \\
{\left[\mathrm{tr} \mathrm{cm}^{-2}\right]}\end{array}$ & $n_{i}$ & $\begin{array}{l}\rho_{\mathrm{d}}\left(\times 10^{5}\right) \\
{\left[\operatorname{tr} \mathrm{cm}^{-2}\right]}\end{array}$ & $n_{d}$ & $P\left(x^{2}\right) \%$ & $\begin{array}{c}\text { AfT Ages } \\
\text { [Ma] }\end{array}$ & $\pm 1 \sigma[\mathrm{Ma}]$ & MTL $[\mu \mathrm{m}]$ & $\pm 1 \sigma[\mu \mathrm{m}]$ & $\begin{array}{r}\text { Std }_{\text {MTL }} \\
{[\mu \mathrm{m}]}\end{array}$ & $n_{T L}$ & $\begin{array}{l}\text { Dpar } \\
{[\mu \mathrm{m}]}\end{array}$ & $\operatorname{Std}_{\text {Dpar }}$ \\
\hline MOR210-06 & 25 & 6.615 & 917 & 5.482 & 760 & 6.3265 & 13062 & 100 & 135.2 & 7.7 & 12.47 & 1.78 & 0.241 & 54 & 2.04 & 0.27 \\
\hline MOR210-07 & 16 & 5.748 & 447 & 4.977 & 387 & 6.3265 & 13062 & 100 & 129.5 & 9.8 & 12.94 & 1.49 & 0.26 & 32 & 1.75 & 0.2 \\
\hline MOR210-09 & 20 & 13.694 & 2014 & 16.699 & 2456 & 6.3265 & 13062 & 89.21 & 92.2 & 3.9 & 12.04 & 1.53 & 0.15 & 102 & 1.73 & 0.19 \\
\hline MOR210-10 & 15 & 12.943 & 1819 & 15.369 & 2160 & 6.3265 & 13062 & 53.31 & 94.7 & 4.1 & 12.69 & 1.56 & 0.15 & 105 & 1.88 & 0.21 \\
\hline MOR210-11 & 13 & 0.247 & 203 & 0.348 & 286 & 6.3265 & 13062 & 100 & 79.9 & 7.7 & - & - & - & 3 & - & - \\
\hline MOR210-12 & 15 & 21.974 & 1637 & 28.257 & 2105 & 6.3265 & 13062 & 99.63 & 87.5 & 3.9 & 12.34 & 1.39 & 0.13 & 118 & 1.84 & 0.17 \\
\hline MOR210-13 & 26 & 8.492 & 918 & 9.732 & 1052 & 6.3265 & 13062 & 92.15 & 98.1 & 5.3 & 12.5 & 1.26 & 0.14 & 85 & 1.93 & 0.31 \\
\hline MOR210-14 & 20 & 5.926 & 611 & 3.094 & 319 & 6.3265 & 13062 & 99.97 & 213.3 & 16 & 13.07 & 1.35 & 0.26 & 26 & - & - \\
\hline MOR210-15 & 15 & 33.682 & 3130 & 23.502 & 2184 & 6.3265 & 13062 & 70.21 & 160.3 & 6.5 & 12.81 & 1.15 & 0.28 & 132 & 2.52 & 0.24 \\
\hline MOR210-16 & 17 & 20.729 & 2181 & 14.865 & 1564 & 6.3265 & 13062 & 99.75 & 156 & 6.9 & 12.45 & 1.16 & 0.12 & 95 & 2.17 & 0.21 \\
\hline MOR210-17 & 25 & 6.095 & 935 & 3.846 & 590 & 6.3265 & 13062 & 99.99 & 177 & 10.7 & 13.56 & 1.02 & 0.15 & 44 & - & - \\
\hline
\end{tabular}

Table 3.2. Apatite Fission track results. $n$ is the number of measured apatite crystals; $\rho_{s}$ is the density of spontaneous tracks; $\rho_{i}$ is the density of induced tracks, and $\rho d$ is the density of fossil tracks in track $/ \mathrm{cm}^{2} ; n_{s}, n_{i}$, and $n_{d}$ are the number of tracks used for the density calculation. $P(\chi 2) \%$ is the chi-squared probability ( $(P>5 \%)$ is a pass). AFT ages are pooled ages; the error is $\pm 1 \sigma$ in million years; MTL stands for mean track lengths and associated to it are the error $\pm 1 \sigma$, the standard deviation SdtM $M_{T L}$ both in $\mu m_{;} n_{T L}$ is the number of measured track lengths. Dpar is the diameter of etched spontaneous tracks measured parallel to the c-axis and is associated to its standard deviation $S d t_{\text {Dpar. }}$ Zeta $(\zeta)=358$ and is the correcting factor defined by Fleischer and Hart (1972); $\sigma(\zeta)=10$ is the uncertainty in zeta (Traditional calibration; Hurford and Green, 1983).

Single grain ages are clustered around the central age of each sample (fig. 3.5A), with reasonable standard deviations of less than $12 \%$. Every sample passed the chi-squared test $(>5 \%)$, which indicates that all samples are characterised by a single age population. The Mean Track Lengths (MTL) range from 11.38 to $13.56 \mu \mathrm{m}$ and the associated errors are ranging from 0.26 to $1.78 \mu \mathrm{m}$ (table 3.2 and fig. 3.5). The MTL of all samples show no correlation with the AFT ages (fig. 3.5B) and the MTL range is characteristic of slow cooling of rocks through the Apatite Partial Annealing Zone (APAZ; Gleadow et al., 1986). On the other hand, the distribution of the track lengths ( $T L)$ for the central and eastern Anti-Atlas is characterised by a fairly narrow Gaussian distribution and abundant long tracks (fig. 3.5A), and suggests a rapid cooling through the APAZ and a long residence time in shallow depths (shallower than the APAZ) or close to the surface (Bigot-Cornier, 2002; Ghorbal et al., 2008).

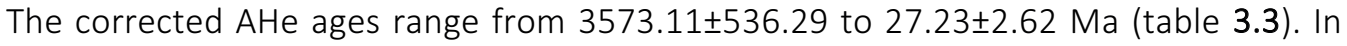
each sample several aliquots are analysed, which allows for a qualitative check on the reproductivity of the age. AHe ages and results were only considered when at least two aliquots within one sample displayed similar ages, with a difference not greater than 10 Myr (ca. average dating error of our aliquots). $70 \%$ of our aliquots replicate within the average error. Aliquots that do not replicate are MOR210-06_II, MOR210-10_III, MOR210-16_I, MOR210-17_I, and all the aliquots from the samples MOR210-07 and MOR210-13, which are therefore discarded (table 3.3). 

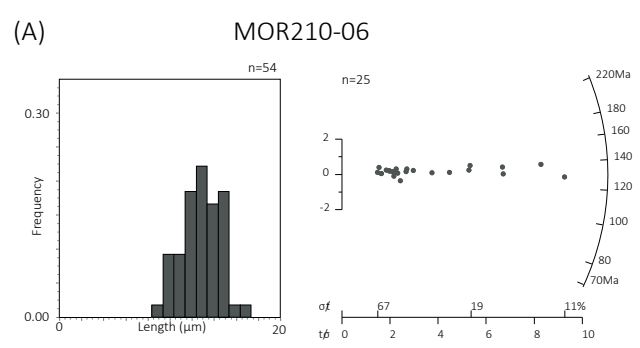

MOR210-07
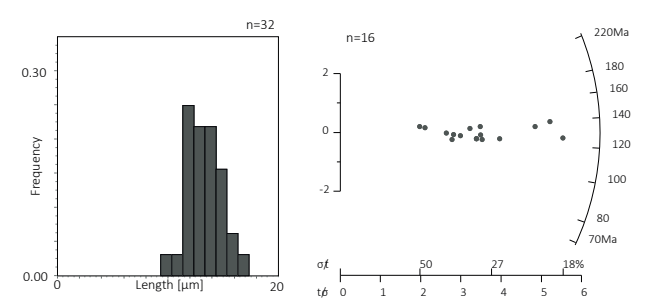

MOR210-09
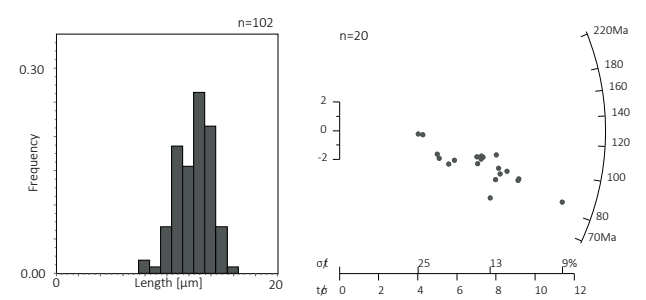

MOR210-10
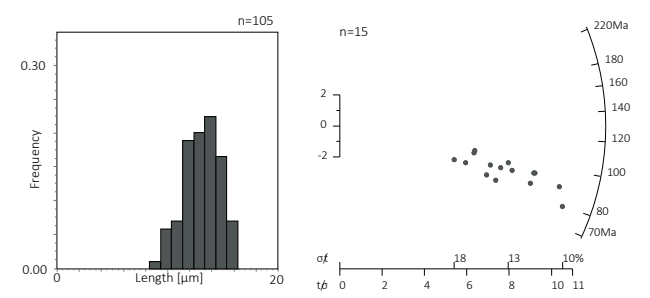

MOR210-12
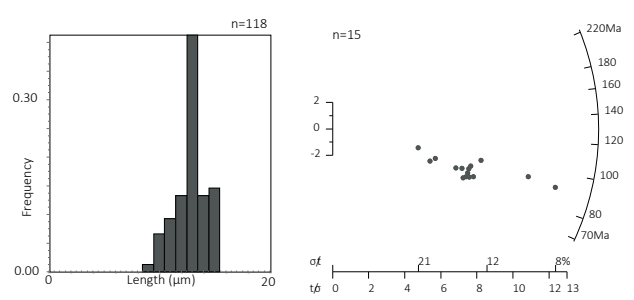

MOR210-13

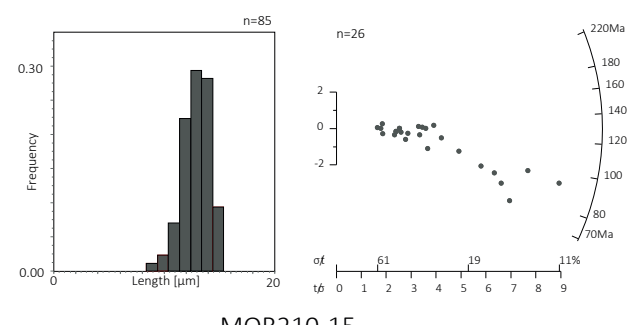

MOR210-15
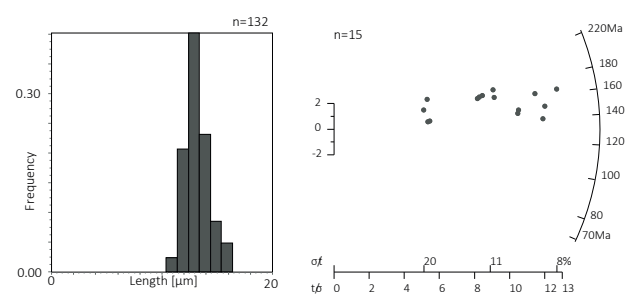

MOR210-16
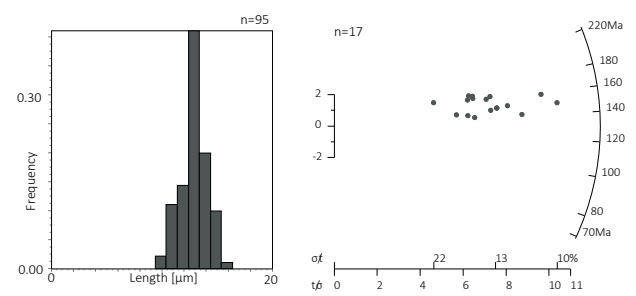

(B)

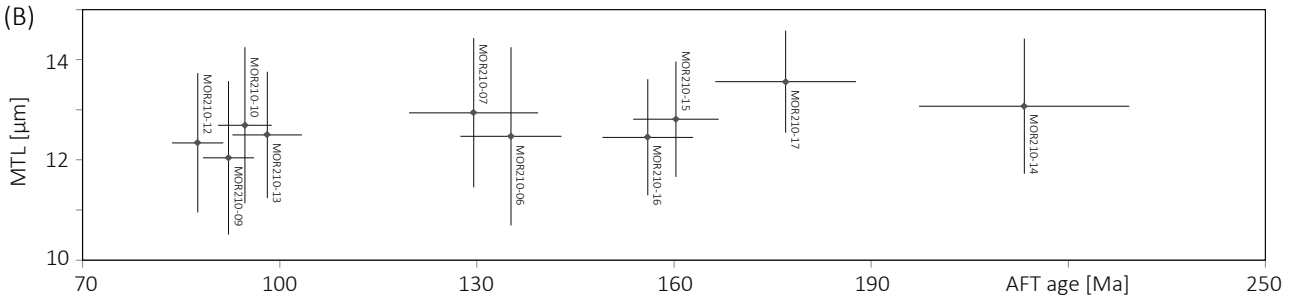

Figure 3.5. A) Track length distribution (left panel) and radial plot (right panel) for 8 out of 12 samples; B) Mean track length (MTL) as a function of apatite fission tracks ages (AFT). 


\begin{tabular}{|c|c|c|c|c|c|c|c|c|c|}
\hline $\begin{array}{l}\text { Sample } \\
\text { Aliquots }\end{array}$ & $\begin{array}{c}\text { Crystal } \\
\text { length }[\mathrm{mm}]\end{array}$ & $\begin{array}{c}\text { Crystal } \\
\text { radius [mm] }\end{array}$ & $\mathrm{Th} / \mathrm{U}$ & $\begin{array}{l}\text { Uncorrected } \\
\text { He age [Ma] }\end{array}$ & $\pm 1 \sigma[\mathrm{Ma}]$ & Ft factor & $\begin{array}{c}\text { Corrected } \\
\text { He age [Ma] }\end{array}$ & $\pm 1 \sigma[\mathrm{Ma}]$ & $\begin{array}{c}\text { Reproducible } \\
\text { ages }\end{array}$ \\
\hline MOR210-06_I & 200.84 & 62.97 & 0.11 & 84.91 & 8.26 & 0.77 & 109.8 & 10.7 & $\bullet$ \\
\hline MOR210-06_II & 160.92 & 49.05 & 3.21 & 2506.64 & 376.22 & 0.70 & 3573.1 & 536.3 & $x$ \\
\hline MOR210-06_III & 170.00 & 71.00 & 2.21 & 89.76 & 11.15 & 0.78 & 115.8 & 14.4 & - \\
\hline MOR210-06_IV & 152.87 & 57.00 & 1.45 & 81.95 & 10.19 & 0.73 & 111.6 & 13.9 & • \\
\hline MOR210-07_I & 216.93 & 75.76 & 0.82 & 125.09 & 12.24 & 0.80 & 156.3 & 15.3 & $x$ \\
\hline MOR210-07_II & 175.88 & 39.99 & 1.44 & 44.40 & 4.29 & 0.66 & 67.4 & 6.5 & $x$ \\
\hline MOR210-07_III & 152.56 & 37.77 & 1.22 & 76.56 & 7.78 & 0.64 & 119.7 & 12.2 & $x$ \\
\hline MOR210-08_I & 95.62 & 24.45 & 0.79 & 47.15 & 4.69 & 0.49 & 96.8 & 9.6 & - \\
\hline MOR210-08_II & 131.52 & 28.16 & 0.03 & 65.39 & 6.58 & 0.56 & 116.2 & 11.7 & - \\
\hline MOR210-08_III & 88.81 & 26.61 & 1.14 & 39.66 & 4.22 & 0.51 & 78.3 & 8.3 & $x$ \\
\hline MOR210-09_I & 315.64 & 154.00 & 0.01 & 65.83 & 6.35 & 0.89 & 73.7 & 7.1 & - \\
\hline MOR210-09_॥ & 234.88 & 85.41 & 0.10 & 56.93 & 5.47 & 0.82 & 69.0 & 6.6 & - \\
\hline MOR210-09_III & 225.59 & 60.58 & 0.03 & 53.32 & 5.41 & 0.77 & 69.0 & 7.0 & - \\
\hline MOR210-10_I & 203.78 & 51.73 & 0.05 & 51.27 & 4.93 & 0.74 & 69.7 & 6.7 & - \\
\hline MOR210-10_II & 207.49 & 70.33 & 0.06 & 56.61 & 5.43 & 0.79 & 71.5 & 6.9 & - \\
\hline MOR210-10 III & 343.96 & 77.98 & 0.17 & 24.66 & 2.37 & 0.82 & 29.9 & 2.9 & $x$ \\
\hline MOR210-10_IV & 207.49 & 61.04 & 0.07 & 59.93 & 5.81 & 0.77 & 77.8 & 7.5 & - \\
\hline MOR210-12_I & 166.18 & 44.79 & 0.05 & 34.45 & 3.35 & 0.70 & 49.3 & 4.8 & - \\
\hline MOR210-12_III & 162.00 & 66.84 & 28.00 & 41.30 & 5.91 & 0.75 & 55.3 & 7.9 & - \\
\hline MOR210-12_IV & 119.76 & 57.09 & 40.66 & 35.37 & 3.91 & 0.70 & 50.9 & 5.6 & - \\
\hline MOR210-13_I & 209.92 & 67.94 & 0.41 & 114.18 & 10.99 & 0.78 & 145.7 & 14.0 & $x$ \\
\hline MOR210-13_II & 120.22 & 45.30 & 1.03 & 81.73 & 7.95 & 0.67 & 121.2 & 11.8 & $x$ \\
\hline MOR210-13_III & 133.68 & 42.70 & 0.60 & 35.50 & 3.40 & 0.67 & 52.9 & 5.1 & $x$ \\
\hline MOR210-14_I & 180.10 & 47.11 & 4.41 & 31.35 & 3.01 & 0.70 & 45.1 & 4.3 & • \\
\hline MOR210-14_II & 122.08 & 39.46 & 2.88 & 30.22 & 3.20 & 0.63 & 47.6 & 5.0 & - \\
\hline MOR210-14_III & 125.79 & 46.19 & 2.97 & 28.75 & 2.80 & 0.67 & 42.7 & 4.1 & • \\
\hline MOR210-15_I & 206.56 & 56.86 & 1.04 & 84.19 & 8.13 & 0.75 & 112.0 & 10.8 & - \\
\hline MOR210-15_II & 161.07 & 60.81 & 1.05 & 85.48 & 8.23 & 0.75 & 113.8 & 11.0 & - \\
\hline MOR210-16_I & 258.08 & 57.33 & 0.82 & 20.78 & 2.00 & 0.76 & 27.2 & 2.6 & $x$ \\
\hline MOR210-16_II & 240.93 & 80.93 & 1.09 & 37.64 & 3.63 & 0.81 & 46.3 & 4.5 & - \\
\hline MOR210-16_III & 179.64 & 46.30 & 1.05 & 28.33 & 2.70 & 0.70 & 40.4 & 3.8 & - \\
\hline MOR210-16_IV & 240.91 & 33.32 & 1.16 & 22.49 & 2.14 & 0.63 & 35.8 & 3.4 & - \\
\hline MOR210-17_I & 187.99 & 43.17 & 3.01 & 51.59 & 4.99 & 0.68 & 75.7 & 7.3 & $x$ \\
\hline MOR210-17_II & 176.39 & 50.83 & 2.95 & 33.65 & 3.27 & 0.71 & 47.1 & 4.6 & • \\
\hline MOR210-17_III & 154.57 & 53.49 & 2.65 & 36.84 & 3.55 & 0.72 & 51.4 & 5.0 & - \\
\hline
\end{tabular}

Table 3.3. Result of the (U-Th)/He analyses. Uncorrected AHe ages are corrected using an Ft factor (all sample but MOR210-08: Farley, 2000). The age replication is explained in the text (• yes; $x$ no). Bold AHe ages are displayed in table 3.1.

Poor AHe age replication within the same sample could be attributed to analytical errors during the He extraction, or more likely to the presence of undetected fluid and/or mineral inclusions in the analysed apatite aliquots. After this step, the corrected AHe ages are between $115.80 \pm 10.68$ to $35.78 \pm 3.41 \mathrm{Ma}$ in the western and eastern AntiAtlas, respectively. Overall, the AHe ages of the selected aliquots seem to become younger towards the east (fig. 3.2A). The eU (effective uranium) of the analysed apatite crystals are between 0.04 and 79.14 ppm (fig. 3.6). In all three geographic domains of the Anti-Atlas we qualitatively observe weak positive correlations between the eU and the AHe ages (fig. 3.6). This may result from several cooling and heating episodes, as already interpreted in areas of NW Africa by previous authors (e.g. Leprêtre et al., 2015; 2017). 
Published AFT ages produced from the Anti-Atlas (Malusà et al., 2007; Ghorbal, 2009; Sebti et al., 2009; Ruiz et al., 2011; Sebti, 2011; Oukassou et al., 2013; Sehrt, 2014) are between $238 \pm 42$ and $88 \pm 3.9 \mathrm{Ma}$ (Malusà et al., 2007), and corrected reproducible AHe ages range from $148.1 \pm 1.5$ (Ruiz et al., 2011) to $36.1 \pm 1.6 \mathrm{Ma}$ (Ghorbal, 2009). With the error bars, our radiometric ages fall within these ranges.
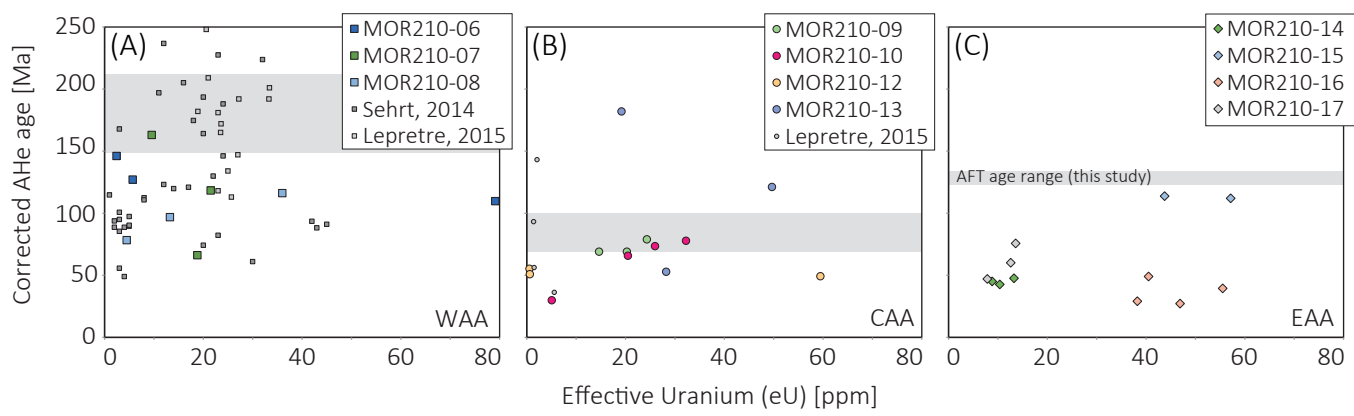

Figure 3.6. Corrected AHe ages v. effective uranium concentration plots for the A) Western, B) Central, and C) Eastern Anti-Atlas.

\subsubsection{LTT temporal/spatial distributions in the Anti-Atlas}

LTT systems (Zircon Fission Tracks, ZFT; Zircon (U-Th-Sm)/He, ZHe; AFT; AHe) and their related ages produced in the Anti-Atlas can be separated into time periods (fig. 3.7). These periods slightly overlap but remain consistent: ZFT from 400 to $250 \mathrm{Ma}$ (closure temperatures of the system: $270-210^{\circ} \mathrm{C}$; Brandon et al., 1998), ZHe from 280 to $180 \mathrm{Ma}$ (200-160 $\mathrm{C}$; Reiners et al., 2005), AFT from 230 to $90 \mathrm{Ma}$ (120-70 C; Green et al., 1989), and AHe from 200 to $20 \mathrm{Ma}\left(110-50^{\circ} \mathrm{C}\right.$; Shuster et al., 2006). Therefore, the first-order trend we could infer from figure 3.7 is a fairly continuous cooling between the Variscan and the present day.

AFT ages become younger towards the north of the central Anti-Atlas and towards the west of the eastern Anti-Atlas (fig. 3.7). In the central Anti-Atlas, the range of AFT ages from Oukassou et al. (2013) (ca. 180-130 Ma) compares to the ones from the rest of the belt (average of ca. $150 \mathrm{Ma}$ ), which is not the case for our results that are somewhat younger (ca. 100-80 Ma). Similar younger AFT ages were produced by Malusà et al. (2007) in the northern edge of the eastern domain (fig. 3.7).

Figure 3.7 shows available corrected and reproducible AHe ages. Considering the error bars, AHe ages are between ca. 200 and $100 \mathrm{Ma}$ in the western, ca. 150 and $40 \mathrm{Ma}$ in the central, and ca. 125 to $20 \mathrm{Ma}$ in the eastern Anti-Atlas. The trend we observed in our data set is therefore representative. Overall, the collected samples show younger AHe ages towards the East. 


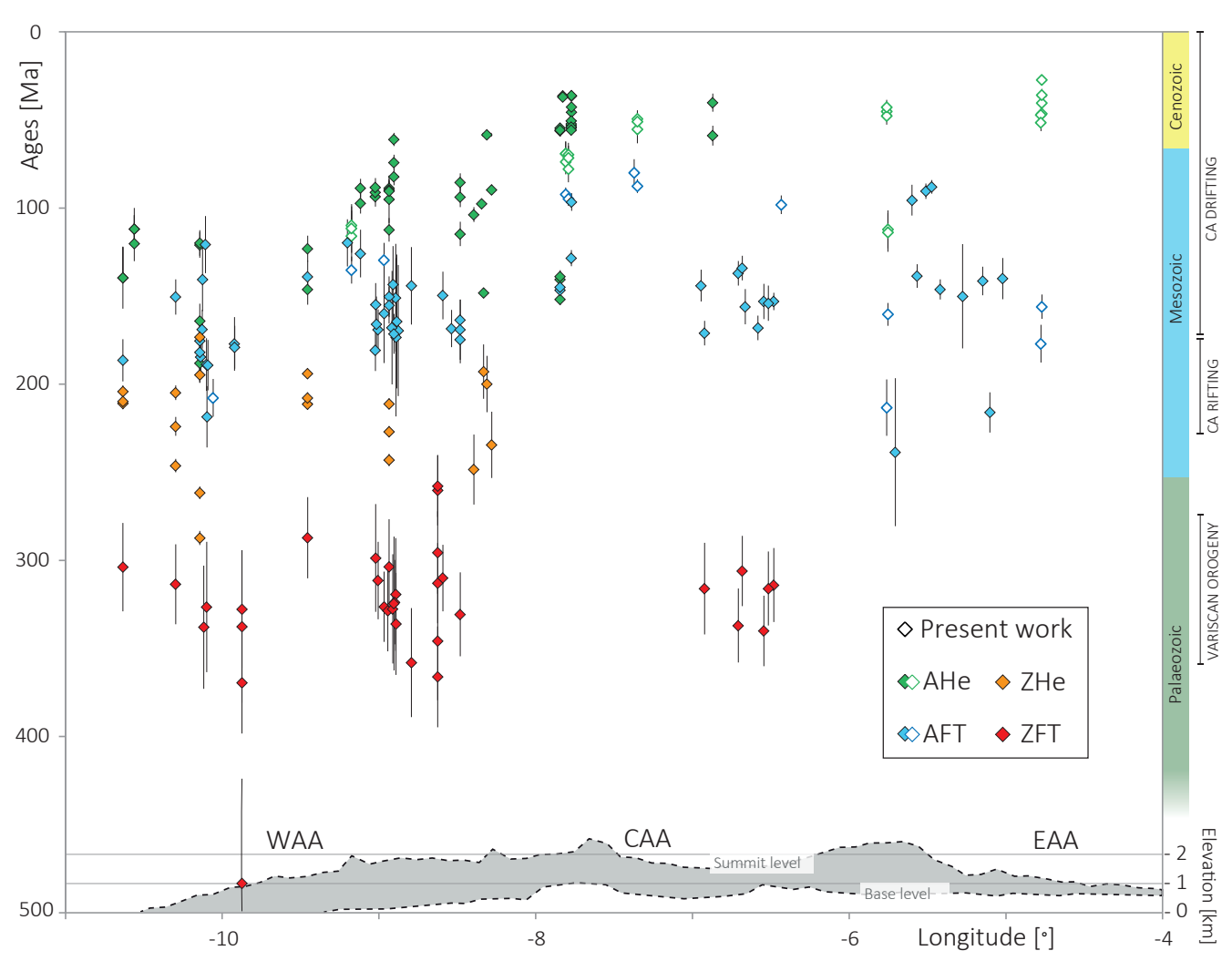

Figure 3.7. LTT data from the Anti-Atlas (references in figure 3.1). The elevation plot (bottom plot) is made from the point extraction from a DEM (SRTM 90m, NASA) of the Anti-Atlas reliefs. Timing of the geological events (right panel) are from Michard et al. (2008). CA: Central Atlantic; CAMP: Central Atlantic Magmatic Province.

\subsection{Modelled Meso-Cenozoic thermal history of the Anti-Atlas}

\subsection{1. t-T modelling: Procedure and parameters}

The $\mathrm{t}-\mathrm{T}$ paths modelled from measured AFT lengths and ages are obtained with the inverse modelling HeFTy software (version 1.8.2; Apatite to Zircon; Ketcham, 2005). The software uses a Monte Carlo algorithm that generates $t-T$ paths that match, to a certain extent (Goodness of Fit based on the Kolmogorov-Smirnov test, GOF), the inputs we implemented. In the present work we use AFT models (composed of the AFT single-grain age data and the confined track lengths) and AHe models (composed of the $\mathrm{AHe}$ uncorrected age, the chemical composition, and size of the apatite crystal). When the average GOF for the fission track length distribution, AHe age, and AFT age model is between 5 and $50 \%$ paths are labelled 'acceptable', and 'good' when higher than 50\%. The 'best fit' realisation is a non-unique solution as it has the highest GOF of $10^{6}$ iterations, but other runs may have different best-fit paths. 


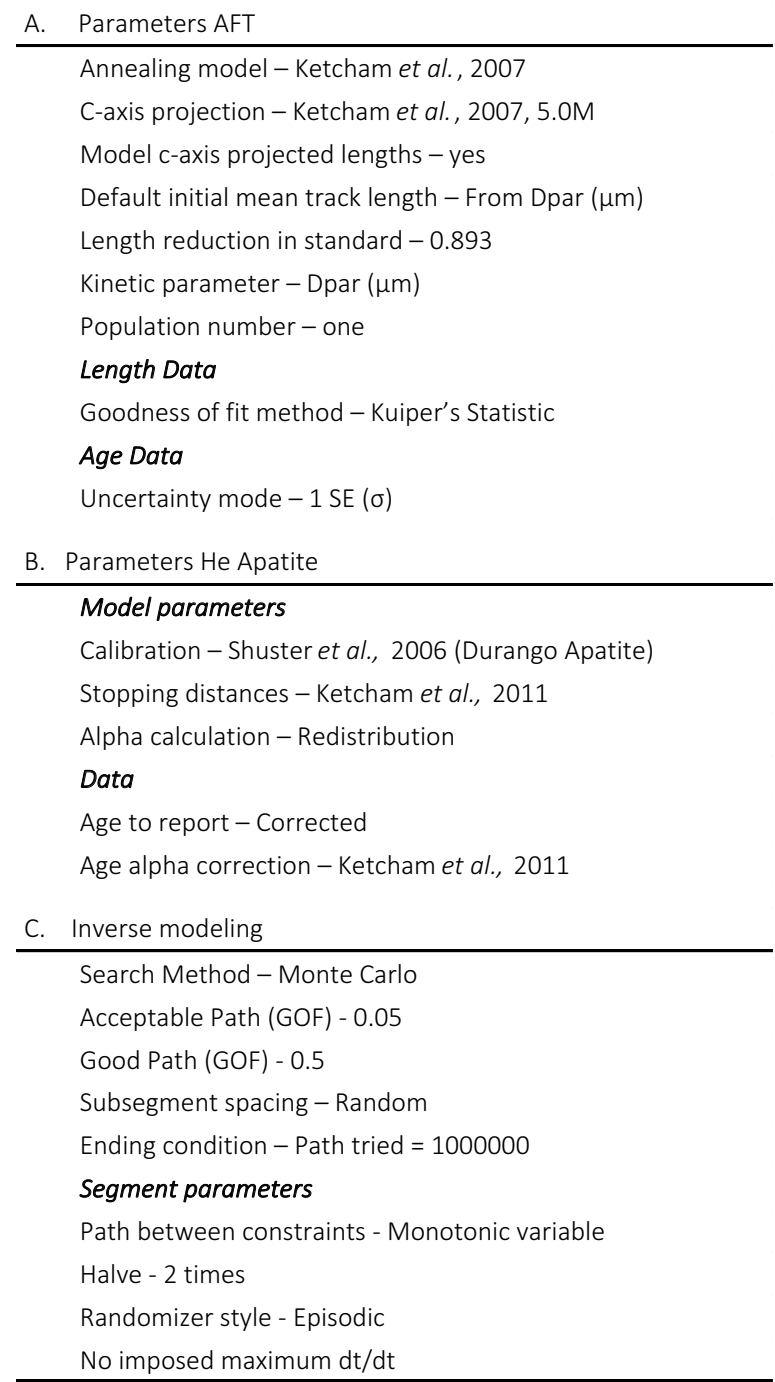

Table 3.4. HeFTy (version 1.8.2) parameters commonly used in each simulation presented in this chapter. A) Parameters used for the AFT models. Cf irradiation, see Donelick and Miller (1991); Dpar is the diameter of etched spontaneous tracks measured parallel to the c-axis; Kuiper's statistic, see Press et al. (1992); SE stands for standard error. B) Parameters used for the AHe models. C) Parameters of the inverse modelling. GOF stands for Goodness of Fit.

The models are constrained between ca. 120 and $40^{\circ} \mathrm{C}$ by the AFT and AHe data; above and below these temperatures there are almost no thermal signals recorded in the LTT data. For the same reasons, the LTT results give insights into the cooling/heating events from the present day to the measured ages. Therefore, outside these time and temperature frames the modelling depends solely on 'boxes'. Geological and radiometric constraints, or boxes, are user-defined $\mathrm{t}-\mathrm{T}$ windows that guide the tested 
generated curves. We consider $72 \%$ of the results from the AFT measurements as analytically reliable for t-T modelling, as 50-200 confined tracks are generally considered reliable (e.g. Laslett et al., 1984; Gallagher et al., 1998; Tagami and O'Sullivan, 2005; Donelick et al., 2005; Balestrieri et al., 2009; Jelinek et al., 2014). We therefore run models with the AFT results of samples characterised by an $n_{T L}$ higher than 50 (table 3.2).

Last, only the couples AFT/AHe were considered, and therefore MOR210-13 is not further used. Six samples were used for t-T modelling, which yielded AFT ages with more than 50 MTL and producible AHe ages (MOR210-06, 09, 10, 12, 15, and 16). Modelling parameters are listed in table $\mathbf{3 . 4}$.

\subsection{2. $\mathrm{t}-\mathrm{T}$ modelling constraints}

Based on the radiometric results and geological observations documented in the AntiAtlas belt and the surrounding domains, we use three constraints to guide the different $\mathrm{t}-\mathrm{T}$ models in HeFTy: two geological and one radiometric (constraint $a$ : CAMP dykes; constraint $\boldsymbol{b}$ : infra-Cenomanian undifferentiated sediments; constraint $c$ : AHe ages). Despite the fact that Variscan metamorphism is fairly well constrained for both time and temperature (fig. 3.8A) in the Anti-Atlas (Ruiz et al., 2008), the produced LTT results have little to no information concerning times before $200 \mathrm{Ma}$. We arbitrarily defined the modelling frame at $240-0^{\circ} \mathrm{C} / 220-0 \mathrm{Ma}$, which take into account the CAMP dykes and undifferentiated Mesozoic sediments geological constraints.

Constrain $a$ is based on the Foum Zguid and Igherm CAMP related dykes (figs. 3.1, 3.2, and 3.4D), outcropping in the Anti-Atlas. The most recent dating displays an age of 196.9 $\pm 1.8 \mathrm{Ma}\left({ }^{40} \mathrm{Ar} /{ }^{39} \mathrm{Ar}\right.$ age on plagioclase; Sebai et al., 1991). They are separated from the Precambrian samples selected for modelling by less than $100 \mathrm{~km}$ with no visible major faults on the geological map. Given their extent, these dykes were emplaced and exhumed to their present elevations together with the surrounding host granitic and sedimentary rocks. The emplacement history of the dykes was constrained by the work of Touil et al. (2008) and Silva et al. (2004, 2010). The analysis of geo-thermometer and geo-barometer showed that these dykes were emplaced at temperature of ca. 600$800^{\circ} \mathrm{C}$ and pressure of 2 to $3 \mathrm{kbar}$. Assuming an average density of $2700 \mathrm{~kg} / \mathrm{m}^{3}$ for the continental crust, Silva et al. (2010) calculated an emplacement depth of 8 to $11 \mathrm{~km}$ for the Zguid dyke. ${ }^{*}$ Considering thermal gradients between 20 and $35^{\circ} \mathrm{C}$, a surface

\footnotetext{
*We learned after the publication of Gouiza et al. (2017a) that the geo-barometer method used in Silva et al. (2010) cannot be reliably used with intrusive rocks (pers. comm. P.Silva). This means that our samples could have been at 8 to $11 \mathrm{~km}$ in depth $200 \mathrm{Ma}$ ago, as well as at shallower/deeper depths. Using a different or modified constraint would most likely impact the gradients of the t-T realisations. In this Thesis, however, we use the constraint $a$ as defined in Gouiza et al. (2017a).
} 
temperature of $20^{\circ} \mathrm{C}$, and a lithostatic density of $2700 \mathrm{~kg} / \mathrm{m}^{3}$, we estimate that the host rocks of the Igherm dyke were at depths of ca. 7.6 to $11.3 \mathrm{~km}$. Considering the metamorphism experienced by the presently outcropping Palaeozoic rocks (Ruiz et al., 2008), the temperature likely did not reach more than $300^{\circ} \mathrm{C}$. Therefore, we consider a low thermal gradient of $25^{\circ} \mathrm{C} / \mathrm{km}$. For the constraint $a$, we hence estimate the temperature range for the host rocks of both dykes between 170 to $240^{\circ} \mathrm{C}$ at $210-190$ Ma.

Constraint $b$ is based on the Mesozoic sediments overlying the Precambrian and Palaeozoic of the Anti-Atlas. Infra-Cenomanian ${ }^{*}$ sediments are lying unconformably on basement rocks in the vicinity of samples collected in the western and central parts of the belt (figs. 3.4A and C; Choubert, 1952; Robert-Charrue 2006; Zouhri et al., 2008; Ghorbal, 2009; Sebti et al., 2009; Ruiz et al., 2011; Sebti, 2011; Oukassou et al., 2013; Sehrt, 2014). A fairly thick package (ca. 1 km offshore Tarfaya; Davison, 2005) of clastics sediments is recognised offshore, on the seismic lines and in the wells, as Upper Jurassic and Lower Cretaceous sediments (e.g. the Tan-Tan and Boujdour Deltas; DSDP 397; Puerto Cansado 1 well). Other undifferentiated early Mesozoic rocks are exposed in the Tarfaya Basin, on the Siroua Massif at both Souss and Ouarzazate basin sides (Hollard et al., 1985). The occurrence of these Mesozoic passive margin clastics, overlying Palaeozoic and Precambrian rocks, is diagnostic for a major regression and/or exhumation that took place in the Moroccan western margin, characterised by the broad erosion of the so-called 'Anti-Atlas Arch' (Frizon de Lamotte et al., 2008 and references therein). The timing of the exhumation remains uncertain. In a recent provenance study, a section of Lower Cretaceous clastic sediments in the north Tarfaya Basin was investigated (geochemical, Nd-Sr isotopic, Ali et al., 2014). The clastics were found to be sourced from the Reguibat Shield, but not from the Anti-Atlas. However, this study regarded part of the Lower Cretaceous sediments (ca. $80 \mathrm{~m}$ out of up to $2 \mathrm{~km}$; Arantegui, 2018). In the eastern termination of the belt, a fairly large area of Middle Cretaceous rocks is exposed (Cenomanian; Benyoucef, 2012; Benyoucef et al., 2015). In the absence of provenance studies carried out in these sediments, we assume that the eastern Anti-Atlas was the source of the Guir Hamada Cenomanian redbeds. Finally, the Anti-Atlas basement was previously modelled to be at/close to the surface by previous t-T modelling studies (Ghorbal, 2009; Ruiz et al., 2011; Oukassou et al., 2013).

\footnotetext{
* The Jurassic age of the redbeds along the shoreline in the western Anti-Atlas (Arantegui, 2018) was evidenced after the publication of Gouiza et al. (2017a). However, the choices we made timing-wise for the constraint $b$ are extremely relevant in the light of this re-dating.
} 

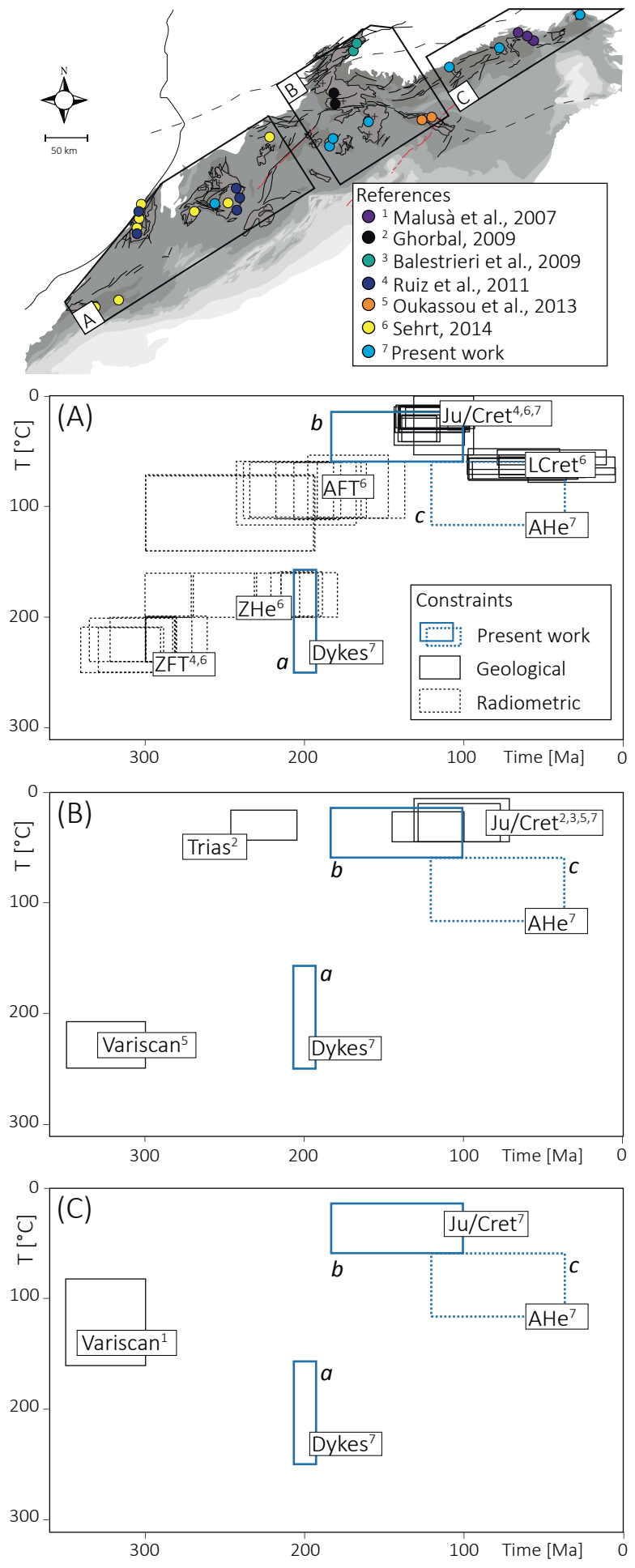

Figure 3.8. Constraints used in $t-T$ modelling from literature (see references in the figure) and from our modelling (blue constraints). A), $B)$, and C) Western, central, and eastern Anti-Atlas, respectively. Variscan: Compression, metamorphism and the load of Palaeozoic sediments; Ju/Cret: Presence close to the surface of the sampled basement rocks during the Late Jurassic to the Early Cretaceous; LCret: Late Cretaceous to Palaeogene overburden in the western Anti-Atlas; Trias: Presence at/close to the surface of the basement rocks in the Siroua during the Triassic; Dykes: See text. 
As our samples are distant of several tens of kilometres from these sediments, we cannot guide our modelling to surface temperatures only. For constraint $\boldsymbol{b}$ we consider that the basement samples were close to the surface $\left(20-60^{\circ} \mathrm{C}\right)$ in the Anti-Atlas possibly from the Early Jurassic to the end of the Early Cretaceous (180 to $100 \mathrm{Ma}$ ).

Constraint $c$ is between the Early Cretaceous and the Eocene (140-40 Ma) to enable the $\mathrm{t}-\mathrm{T}$ paths to re-enter the APAZ and $\mathrm{He}-\mathrm{PAZ}\left(40-120^{\circ} \mathrm{C}\right)$. This box is necessary because our sensitivity modelling experiments showed that HeFTy tends to only generate paths in shallow temperature between the Early Cretaceous and the present-day, ignoring the AHe ages. This method was used in previous works in the Anti-Atlas, for t-T modelling, by adding AFT, AHe, ZFT, and ZHe ages as constraints (Ruiz et al., 2011; Sehrt, 2014; Coutand, pers. com.).

The constraints in published studies of the Anti-Atlas are compared with those of this chapter (fig. 3.8). The CAMP Dyke constraint is centred on equivalent temperature to the 'ZHe' boxes used by Sehrt (2014) for the western Anti-Atlas. The constraints for Jurassic/Cretaceous presence close to the surface have been used similarly for the western and central Anti-Atlas, but not in the eastern part of the belt (fig. 3.8C). The radiometric constraint (AHe) does not compare with previous constraints in the central and eastern Anti-Atlas, but is not incompatible with Late Cretaceous burial constraint (Sehrt, 2014) in western Anti-Atlas (fig. 3.8A). In the central Anti-Atlas (fig. 3.8B), some samples were thought to be close to the surface in the northernmost central Anti-Atlas during the Triassic (Ghorbal, 2009), which are equivalent to one constraint added in t-T modelling of the Meseta basement rocks (Ghorbal et al., 2008). Unlike the Meseta (e.g. Ghorbal et al., 2008) the basement rocks of the Anti-Atlas are not thought to have been at the surface during the Triassic. However, Triassic sediments are found on top of the basement north of the Siroua (Chevalier et al., 2001). Sedimentological (Baudon et al., 2009), structural (El Arabi et al., 2003), and radiometric (e.g. Ghorbal, 2009) analyses also suggest that the basement rocks of the Siroua and Massif Ancien were forming a relief during the deposition of these sediments. ZHe ages were produced in the western Anti-Atlas, and are between 248.4 \pm 19.9 and 192.8 $\pm 15.4 \mathrm{Ma}$ in Ruiz et al. (2011), and $287.3 \pm 4$ and $87 \pm 2 \mathrm{Ma}$ in Sehrt (2014; fig. 3.7). The presence of sampled rocks at surface temperature during the Triassic is therefore incompatible with ZHe ages.

\subsection{3. $\mathrm{t}-\mathrm{T}$ modelling results}

HeFTy succeeded in finding t-T paths that honour the AFT/AHe results (figs. 3.9 and 3.10). The results indicate a common trend, marked by two cooling and one heating episodes. A steep cooling gradient is observed in all the models, especially in MOR21006, 12, and 16. A Cretaceous heating and a final Late Cretaceous to present-day cooling episodes are present in every model. 

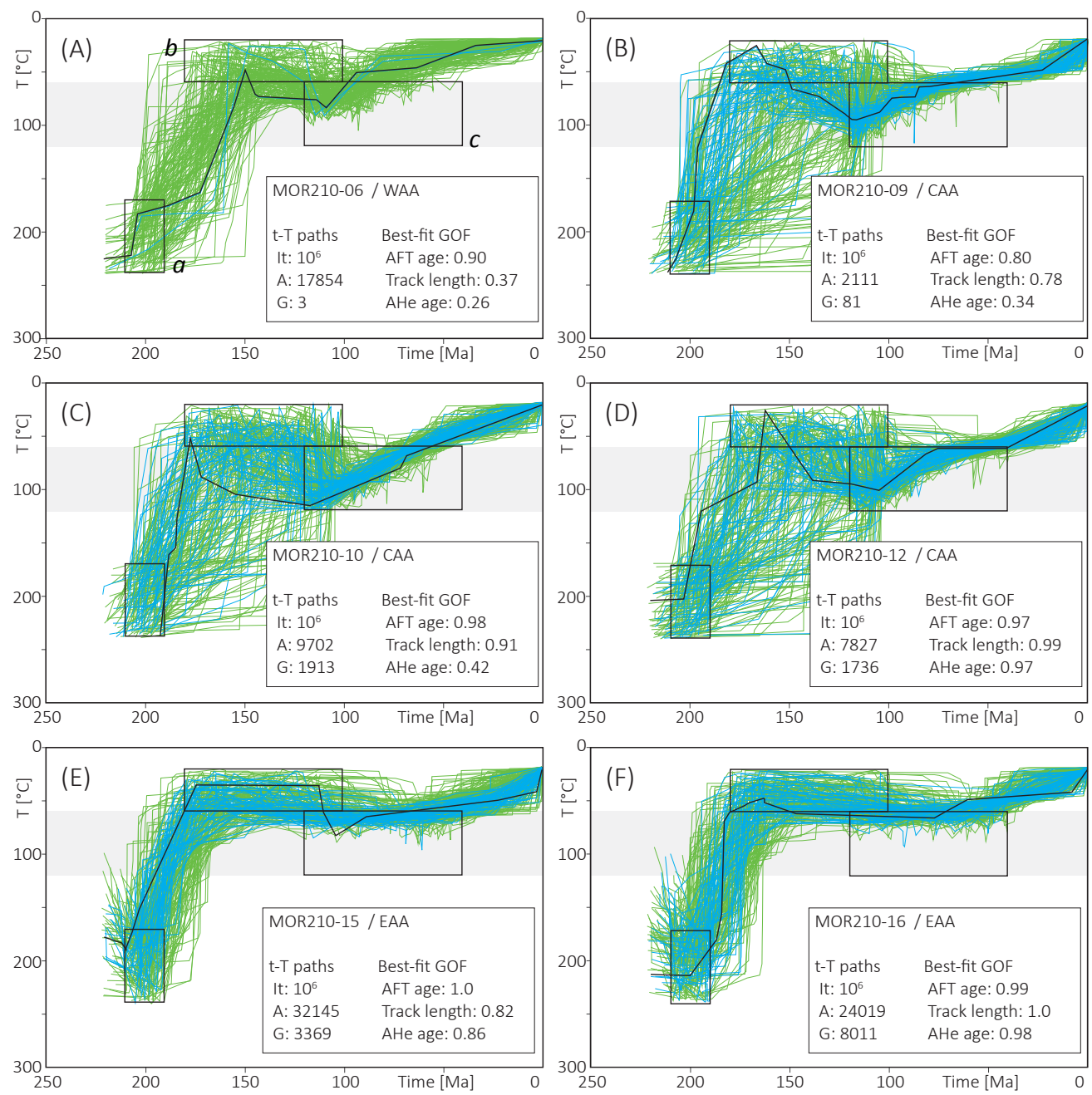

Constraints

APAZ $\curvearrowright$ Best Fit

Good Fit (GOF>0.5) Acceptable Fit (GOF>0.05)

Figure 3.9. Results of thermal history modelling for samples from the Anti-Atlas granitic basement; WAA, CAA, and EAA: Western, Central, and Eastern Anti-Atlas, respectively. 50 good (when possible), 150 acceptable, and the best-fit (highest Goodness of Fit; GOF) t-T curves are displayed. See parameters in table 3.4. It: Number of iteration for the inverse modelling; A: Acceptable paths; G: Good paths.

* The modelling was performed by Mohamed Gouiza. 
The first cooling event brought the Anti-Atlas sampled basement from high temperatures of $240-190^{\circ} \mathrm{C}$ to lower temperatures of $60-25^{\circ} \mathrm{C}$. It started by the end of the Triassic (210-190 Ma) and ended at variable times in the different domains of the belt. Since our modelling experiments only capture the post-Triassic evolution of the Anti-Atlas, this cooling could have initiated much earlier than illustrated in our models, as suggested in figure 3.7. The best-fit t- $T$ paths show a rapid initial cooling phase that ended around 180-150 Ma. After this first cooling event, the basement rocks of the western and central Precambrian domes were heated again and reached temperatures ranging between 85 and $115^{\circ} \mathrm{C}$ around $120-105 \mathrm{Ma}$ (figs. 3.9A-D). However, in the eastern Anti-Atlas, the basement remained stable at around $40^{\circ} \mathrm{C}$ from 170 to $110 \mathrm{Ma}$, before experiencing a rapid (112-103 Ma) $40^{\circ} \mathrm{C}$ heating event (fig. $\left.3.9 \mathrm{E}\right)$, while the easternmost sample underwent a slow and prolonged (160-80 Ma) heating event of only $15^{\circ} \mathrm{C}$ (fig. 3.9F). The final cooling phase, which placed the basement rocks at surface temperature $\left(\mathrm{ca} .20^{\circ} \mathrm{C}\right.$ ), was much slower than the older modelled cooling phase and lasted longer (ca. $120 \mathrm{Ma}$ ) in all the examined samples.

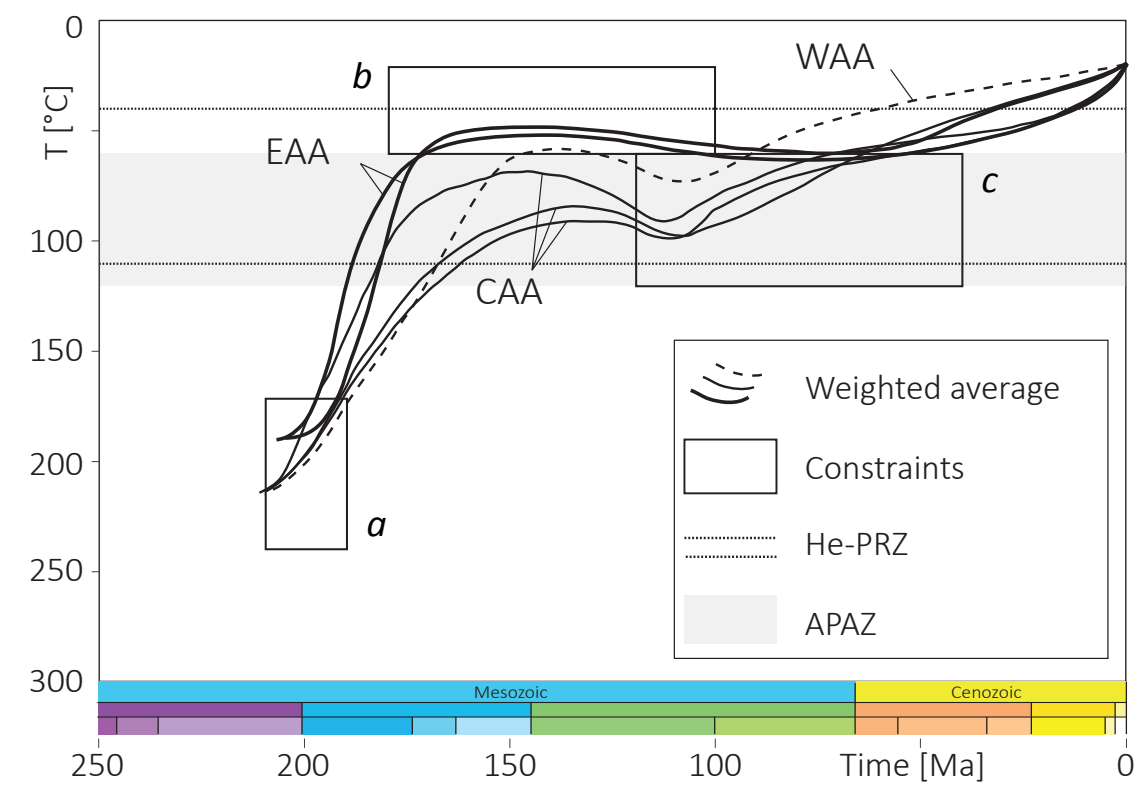

Figure 3.10. Weighted average curve from $t-T$ modelling results shown in fig. 3.9; WAA, CAA, and EAA: Western, Central, and Eastern Anti-Atlas. See modelling parameters in table 3.4.

\subsection{4. t-T modelling: Comparison with literature}

Our model best-fit paths, displayed in figure 3.11, show many similarities with those of the literature. They illustrate a thermal evolution, which is also characterised by two cooling periods separated by a heating event in the western and central Anti-Atlas (figs. 3.11A and B), and by a continuous cooling phase in the eastern Anti-Atlas (fig. 3.11C). Importantly, the Cenozoic temperature evolution is fairly identical between all curves, and should be considered as robustly constrained in HeFTy by the AFT/AHe data. 

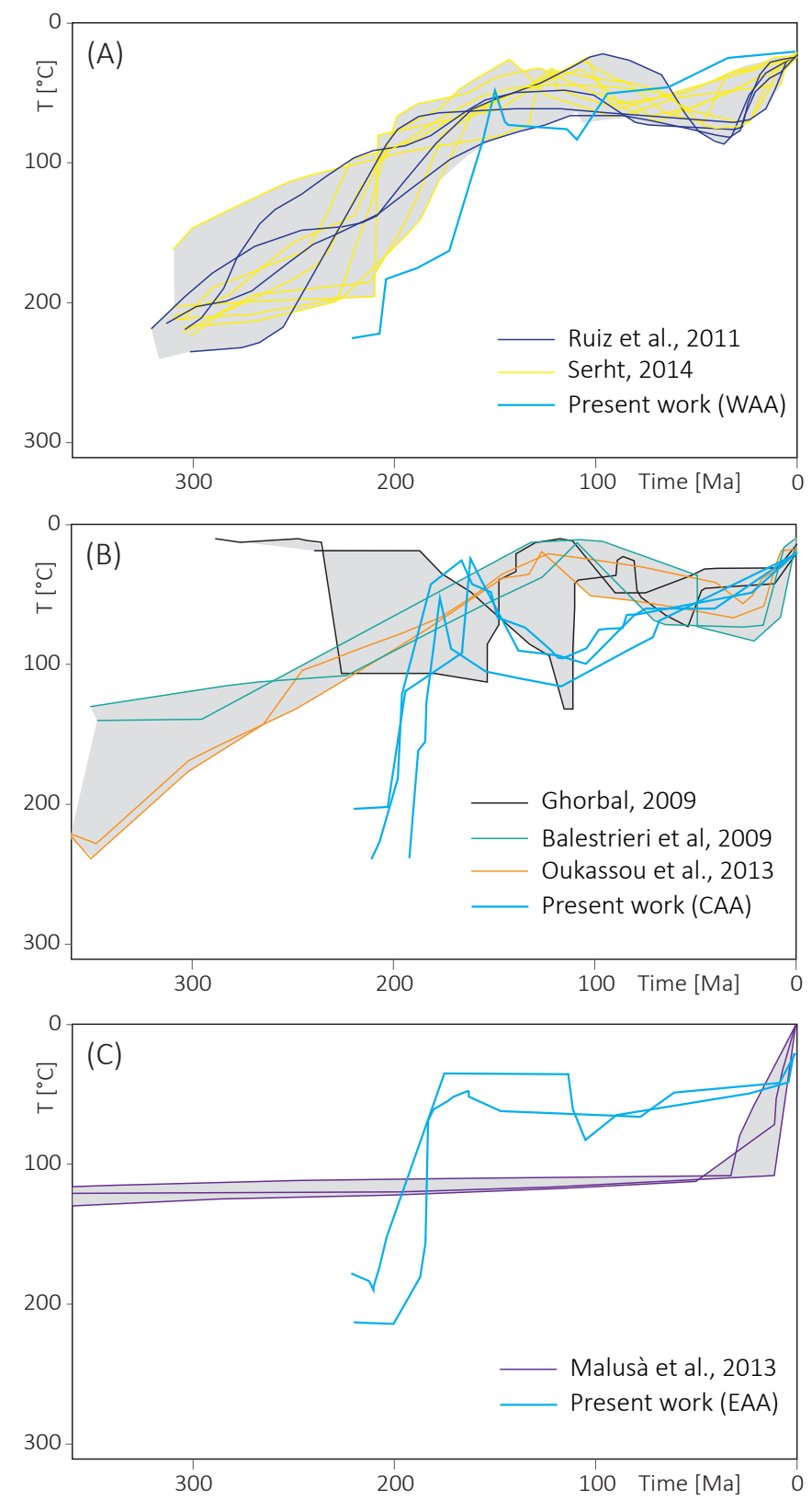

Figure 3.11. Best fit curves of $t-T$ models from the literature (thin lines) and our simulations (thick blue lines) for the regions investigated in the present work: A) Western Anti-Atlas; B) Central Anti-Atlas; C) Eastern Anti-Atlas. Grey envelopes are framing the best-fit models from the literature (see references in the figure). 
However, major discrepancies are observed in the timing and rates of each thermal event. For instance, Ruiz et al. (2011) predicted the heating event in the western Precambrian domes to be 50 to 60 Myr younger than in our models (fig. 3.11A). In the eastern domain Malusà et al. (2007) obtained a post-Variscan thermal evolution characterized by a continuous slow cooling during the Mesozoic and high cooling rates during the Cenozoic, and no heating event as showed in our models (fig. 3.11C).

In the central Anti-Atlas during the Late Jurassic/Early Cretaceous, our best-fit results show greater heating of the rocks than in the literature (up to $100^{\circ} \mathrm{C}$ against $60^{\circ} \mathrm{C}$, respectively). The discrepancies between the different thermal histories result mainly from the different constraints imposed on the models. Although, our models account for both AFT and AHe data, most of the published t-T paths rely solely on FT data (except Sehrt, 2014). Moreover, all the published models ignore the nearby CAMP dykes, which are documented to be emplaced at 8 to $11 \mathrm{~km}$ in depth by the end of the Triassic (Touil et al. 2008; Silva et al. 2010).

\subsection{Geological evolution and thermal transects of the Anti-Atlas}

We built several Anti-Atlas paleo-temperature transects oriented WSW-ENE (fig. 3.12). The sample locations were orthogonally projected to a line running parallel to the AntiAtlas trend with an angle of $27^{\circ}$ with the $27 \mathrm{~N}$ degree line of latitude (fig. 3.12A). In the following sections, we also develop on supporting geological evidences documented in the Anti-Atlas or in its surroundings.

\subsubsection{Palaeozoic basin, Variscan orogeny, and pre-rift stage}

The basement rocks are overlain with a marked unconformity by Late Neoproterozoic sediments and volcanics and Cambrian sediments (fig. 3.3; ca. 600-510 Ma; Michard et al., 2008). This requires the Precambrian basement to be at or close to surface temperatures at the beginning of the Palaeozoic. The Anti-Atlas was then characterised during that time by a fairly continuous sedimentation, reviewed by several authors (e.g. Choubert, 1952; Piqué, 2001; Burkhard et al., 2006; Michard et al., 2008). U-Pb provenance study on zircon showed that the Hoggar (Tuareg Shield, SE Algeria) was a likely source of the siliciclastic Cambrian sediments (Avigad et al., 2012). Soulaimani et al. (2014) suggested that a source of Cambrian to Devonian Anti-Atlas sediments was located in the south, and therefore could be the Reguibat shield. In the eastern AntiAtlas, the heating of Devonian rocks was estimated to reach temperatures comprised between 120 and $310^{\circ} \mathrm{C}$ with conodont colour alteration index (CAl of 3 to 5, Belka, 1991).

The Palaeozoic series thickness is estimated to be about $10 \mathrm{~km}$ in the western to central Anti-Atlas and decreases down to $4 \mathrm{~km}$ toward the eastern part (e.g. Faik et al., 2001; Michard et al., 2008). The end of the Palaeozoic, from Late Carboniferous to Early Permian, is characterized by the inversion and folding of the Anti-Atlas basin (Variscan 
orogeny). Soulaimani et al. (2014) estimated a temperature range for the basement rocks of the Anti-Atlas during the folding of the Palaeozoic series (330-310 Ma) based on ZFT, K/Ar, and ${ }^{40} \mathrm{Ar} /{ }^{39} \mathrm{Ar}$ from the western Anti-Atlas. Temperatures of the basement at the base of the Palaeozoic series were comprised between 230 and $300^{\circ} \mathrm{C}$, which are high enough to reset the ZFT system (Pagel et al., 2014), and within the estimation of Ruiz et al. (2008) from illite crystallinity of $300 \pm 20^{\circ} \mathrm{C}$ for the upper part of the basement (epizone). In the central and eastern Anti-Atlas, the metamorphic zones of the lower most Palaeozoic sediment were estimated to anchiozone/epizone $\left(\sim 200-300^{\circ} \mathrm{C}\right)$ and anchiozone/diagenetic zone $\left(\sim 100-250^{\circ} \mathrm{C}\right)$, respectively (illite crystallinity; Ruiz et al., 2008). The basement rocks are usually described as of low to medium metamorphism grade (150-300 $\mathrm{C}$; Buggisch and Flügel, 1988; Soulaimani, 1998; Ruiz et al., 2008). The above-mentioned temperatures are reported onto the first paleo-transect (fig. 3.12B).

At $300 \mathrm{Ma}$, Precambrian outcrops were therefore at temperatures of more than ca. 200, 150 , and $120^{\circ} \mathrm{C}$, for the western, central, and eastern Anti-Atlas, respectively (fig. 3.12B). The relief of the belt during the Variscan mountain building was likely higher than the actual one (exceeding several $\mathrm{km}$ high according to Burkhard et al., 2006), perhaps with a similar bulge shape (fig. 3.2A). During the Carboniferous, the Tindouf basin was likely fed by terrestrial sediments sourced from the Anti-Atlas (Cózar et al., 2014).

Little is known of the Permian and Early Triassic in Morocco. The few outcrops mapped as Permian are concentrated in the Meseta and western High Atlas, and are composed of terrestrial sediments (Broutin et al., 1998). The basement of the Anti-Atlas and its Palaeozoic cover might have started to move upward as early as the Permian/Early Triassic. The Variscan unconformity is well known across Morocco (figs. 3.3B) as a Variscan/undifferentiated Triassic contact in the Meseta, Souss, and Tarfaya basins; Variscan/Middle Cretaceous contact in the Tindouf and Ouarzazate basins and Guir Hamada, and suggests that the Variscan chain was partially peneplained prior to the Late Triassic (fig. 3.12C; reviewed in Michard et al., 2008).

\subsubsection{End of Triassic to Jurassic cooling episode}

The end of Triassic to Middle Jurassic thermal episode is characterised by cooling rates between 3 and $7^{\circ} \mathrm{C} / \mathrm{Myr}$. We interpret this cooling event as related to crustal exhumation/denudation. This exhumation extended beyond the Anti-Atlas senso stricto. into the interior of the African Continent, i.e. over $>600 \mathrm{~km}$ (figs. $3.12 \mathrm{E}$ and F). Indeed, we have no evidence for an eastern termination of this exhumation in the Anti-Atlas. One Early Jurassic AFT cooling age $(175 \pm 7.5 \mathrm{Ma})$ was produced from the Ougarta mountains in Algeria (Akkouche, 2007), $250 \mathrm{~km}$ southwest of our easternmost sample. 


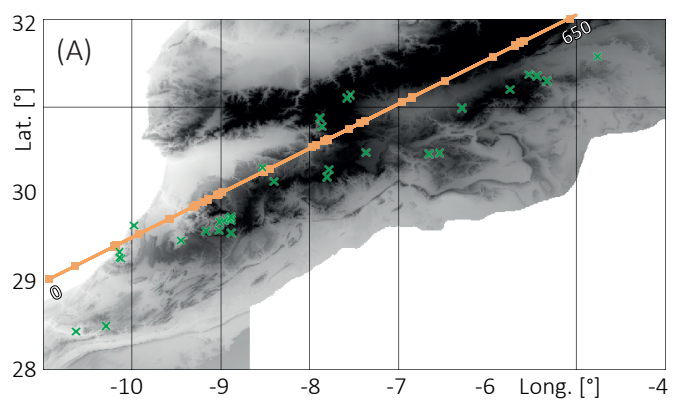

Map

(5) Distance from origin (0) on projection [km]

$\times$ Original position of the sample

- Projection line (parallel to the Anti-Atlas trend)

Temperature transects

Temperature of the 'best-fit' models (literature)

Temperature of the 'best-fit' models (this chapter)

(B)

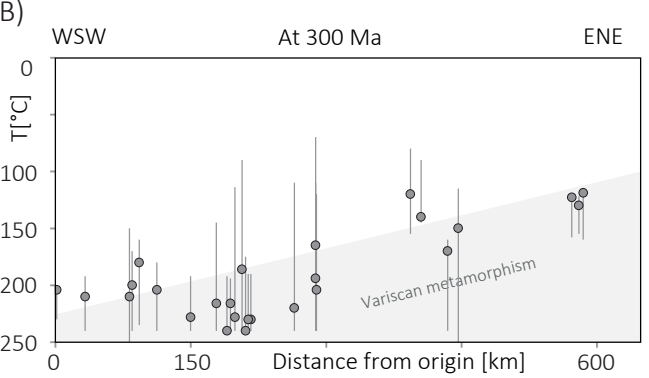

(C)

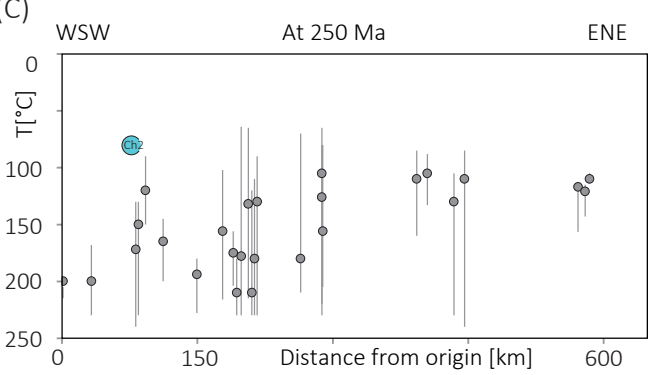

(D)

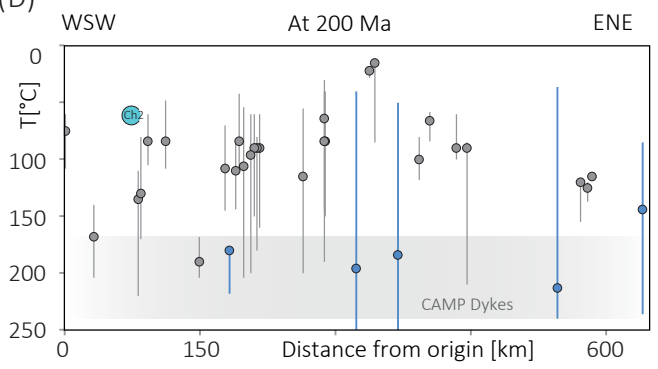

(E)

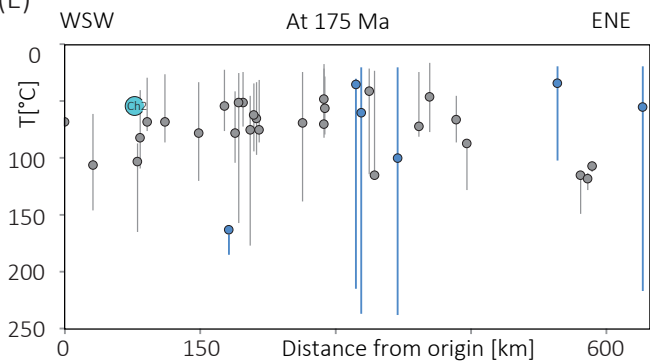

Figure 3.12. Palaeo-temperature transects of the presently outcropping rocks from the Precambrian Anti-Atlas. A) DEM (SRTM 90m, NASA) map with the projection line; B-K) 300$20 \mathrm{Ma}$ temperature transects. The error bars were provided by the envelopes of the realisations with a good GOF. 
(F)

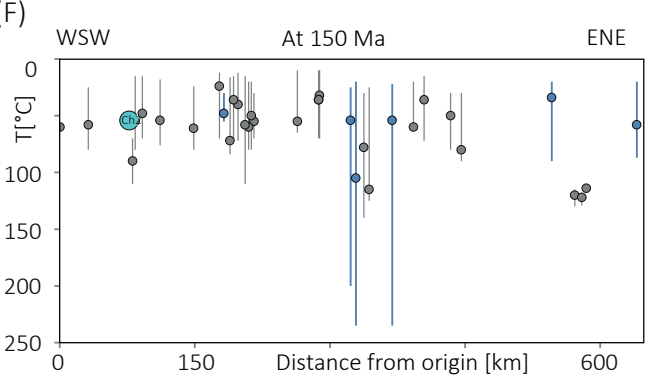

$(\mathrm{H})$

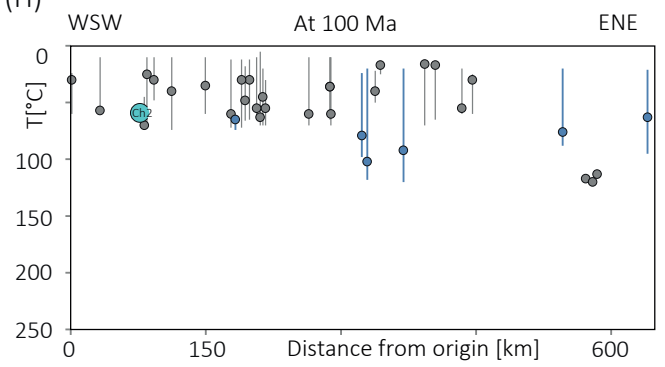

(J)

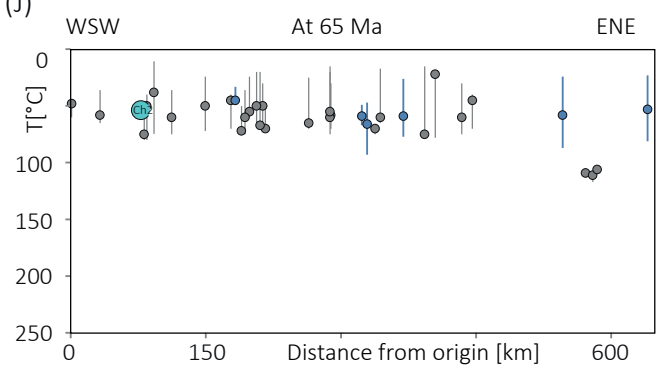

(G)

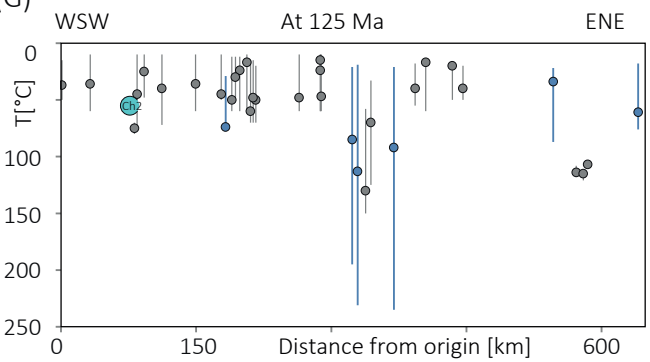

(I)

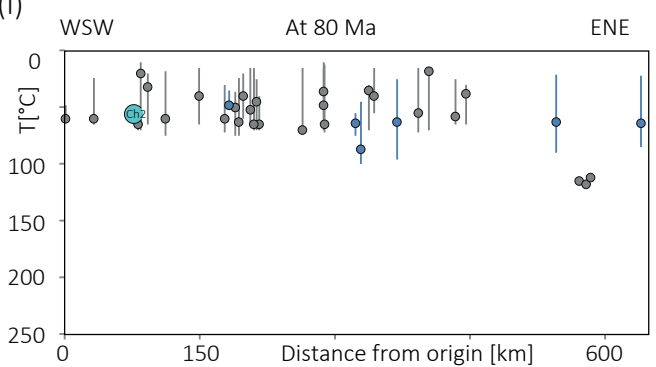

(K)

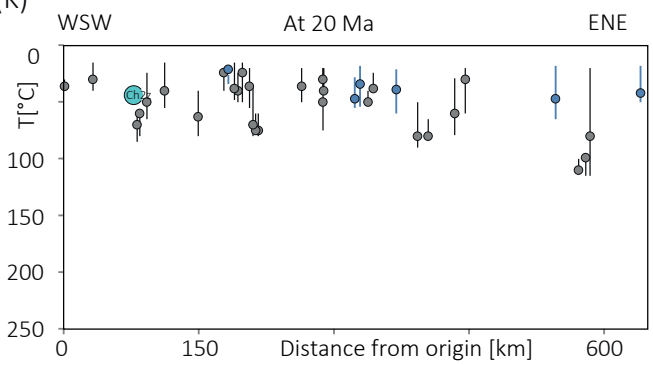

Figure 3.12. (continued) We assume that the post-Variscan exhumation of the Anti-Atlas has only a vertical component (no horizontal), meaning that the relative position of the samples remained similar within the Moroccan margin. Ch2: Temperature of the 'best-fit model of the Sidi Ifni granite (chapter 2).

* The paleo-temperatures from chapter 2 (sample MES01 from the Sidi Ifni area) are shown on figure 3.12 but are not discussed in the text of this chapter. 
In the Tarfaya basin, Ranke et al. (1982) documented that towards the top of the Middle Jurassic, the number of sand layers is increasing. They concluded that these layers were likely fed by the erosion of a 'rising hinterland' in the south (Reguibat Shield) and east (Anti-Atlas). We consider that throughout the Jurassic, the Palaeozoic series covering the Anti-Atlas were partially eroded, feeding clastic sediments in the Tarfaya and Souss basins.

Redbeds and sandstones are recognised in the Lias and Dogger (fig. 3.3) of the Souss basin (e.g. well EGA-1; Samaka and Bouhaddioui, 2003), Essaouira-Agadir Basin (Duval Arnould, pers. com.), and Central High Atlas (e.g. Allain Ronan et al., 2004). The source of these sediments appears to be the Anti-Atlas, eroding the basement and its Palaeozoic cover.

\subsubsection{Late Jurassic to Early Cretaceous subsidence}

Results show a widespread heating event starting in the Late Jurassic (figs. 3.12F, G, and H). The Anti-Atlas was completely to partially covered by sediments, while the depocenter of this subsidence event was located in the north of the central Anti-Atlas and west of the eastern Anti-Atlas. Considering a temperature gradient of $25^{\circ} \mathrm{C} / \mathrm{km}$ (ca. average for Morocco; Zarhloule, 2004), we obtain a depth of ca. 1-3 km to be consistent with our results. Considering that the studied rocks were at ca. $1 \mathrm{~km}$ depth in the previous period, the sediment column should have been at most $2 \mathrm{~km}$ in the central Anti-Atlas. Burial gradients are between 0.1 and $1^{\circ} \mathrm{C} / \mathrm{Myr}$, which translates into a subsidence rate of up to $0.04 \mathrm{~km} /$ Myr (using the thermal gradient of $25^{\circ} \mathrm{C} / \mathrm{km}$ ).

The subsidence of the Anti-Atlas basement was coeval with the post-rift phase of the Central Atlantic. The increase of subsidence towards the central domain resembles the evolution of the High Atlas trough, with a Mesozoic depocenter located in the central part of the rift system (Ellouz et al., 2003; Barbero et al., 2007; Gouiza et al., 2010). Ruiz et al. (2011) proposed that a basin developed in the late Early Cretaceous; with the basement rocks located at $\pm 1 \mathrm{~km}$ in depth $\left(\mathrm{ca} .50^{\circ} \mathrm{C}\right.$ ) and was also proposed in previous studies (Guiraud et al., 2005; Swezey, 2009; Soulaimani et al., 2014).

\subsubsection{Late Early Cretaceous to present-day exhumation}

Our samples yielded Late Cretaceous AFT ages in the central Anti-Atlas, in line with previous works (e.g. Malusà et al., 2007; Ghorbal, 2009). This implies that these rocks were buried deeper than elsewhere in the belt, during the Early Cretaceous, as apatites of these samples must have re-entered the total annealing zone. The $\mathrm{t}-\mathrm{T}$ modelling results show that after the Late Jurassic-Early Cretaceous subsidence the sampled AntiAtlas basement rocks were exhumed (figs. $3.12 \mathrm{H}$ to $\mathrm{K}$ ).

The early Late Cretaceous is characterised by a major transgression and lasted from the Cenomanian to the Turonian (Schlanger and Jenkyns, 1976; Lüning et al., 2004). The widespread occurrence of Cenomanian-Turonian outcrops, recognised in the north and 
south of the eastern Anti-Atlas with similar facies (Guimerà et al., 2011) and in the Tarfaya, Souss, and Ouarzazate basins are evidences of this transgression. The thickness of the Upper Cretaceous marine sediment is ca. $1 \mathrm{~km}$ offshore Tarfaya (Davison, 2005; well 51A-1), less than $1 \mathrm{~km}$ in the Ouarzazate and Souss basin (Missenard, 2006), and the Palaeogene is lacking. Therefore, the thickness of both series could have been greater. The presence of Cenomanian clastic sediments in the Guir Hamada was recently confirmed by extensive paleontological works (e.g. Benyoucef et al., 2012, 2015). Sauropod and Crocodilian ichnofacies showed that an emerged land was nearby these sediments, which according to our modelling results, was the Anti-Atlas. Therefore, the belt was surrounded by immersed areas. We estimate the cooling rate between 0.5 and $0.7^{\circ} \mathrm{C} / \mathrm{Ma}$. This is an order of magnitude lower than the previous Jurassic exhumation.

Given that at least two important sandstone layers are observed throughout the Palaeozoic column (fig. 3.3), the sediments resulting from the erosion of Anti-Atlas contain, a priori, apatite crystals. If basement rocks of the Anti-Atlas and its cover were at the surface during the Palaeogene/Neogene, assuming the western, central, and eastern Anti-Atlas as potential sources, the related terrestrial sediment in the Tarfaya basin would have apatites bearing AFT ages of early Late Cretaceous (ca. 100-80 Ma), as well as older AFT ages ranging from ca. 120 to $220 \mathrm{Ma}$ (fig. 3.7). Sehrt (2014) investigated the north Tarfaya basin and obtained seven AFT ages ranging from 91.6 \pm 16.2 to 237.2 $\pm 35.8 \mathrm{Ma}$ for Miocene and Pliocene sandstones (ca. 92, 104, 142, 142.5, 145, 183, and $237 \mathrm{Ma}$ ). We therefore submit that the entire Anti-Atlas (western and central parts at least) was a sedimentary source for the Neogene sandstones of the north Tarfaya basin.

The thickness of missing sediments deposited before the onset of the plate convergence in the north central Anti-Atlas is ca. $2 \mathrm{~km}$. The thickness of Precambrian/Palaeozoic rocks remaining atop the samples by the end of the Middle Jurassic is ca. $1 \mathrm{~km}$. Once both thicknesses are added, we suggest that the Anti-Atlas must have been exhumed by 3 $\mathrm{km}$. This does not account for surface uplift, which has to bring these rocks at ca. $1.5 \mathrm{~km}$ in elevation. Overall, if the Alpine deformation is mild, the vertical movements occurring during that event are more significant than previously thought. 


\subsection{Conclusions}

The analytical and numerical analyses of new AFT and AHe ages shed light on the AntiAtlas thermal and geological evolution. The sampled basement rocks were at/close to the surface during the end of the Neoproterozoic to the Early Cambrian. They underwent burial and heating due to the marine and clastic sedimentation (Anti-Atlas Palaeozoic basin) until the onset of the Variscan orogeny, which resulted in shortening and folding of the Palaeozoic series. The Variscan relief was peneplained prior to the Triassic.

The acceleration of the exhumation occurred near the Triassic/Jurassic boundary. The presently exposed basement rocks were exhumed from ca. 8-11 km in depth, from the end of the Triassic to the Middle Jurassic. The western termination of the exhumation was not constrained. However, one AFT age collected further into the interior of the African plate suggests that the exhumation extended farther east of the Anti-Atlas, i.e. $>600 \mathrm{~km}$.

The Palaeozoic cover was partially eroded, indicating that the Anti-Atlas was most likely the source of terrestrial sediments shed to surrounding basins: Tarfaya (onshore/offshore), Souss/Essaouira-Agadir, and north Ouarzazate/Central High Atlas basins. Subsidence started in the Anti-Atlas at the end of the Jurassic, and lasted until the Early Cretaceous. The depocentre was located in the centre and north of the eastern Anti-Atlas, where the AFT ages were reset. We estimate the thickness of the sedimentary column to be ca. $2 \mathrm{~km}$, decreasing to ca. $1 \mathrm{~km}$ towards the north-eastern and the south-western edges of the belt.

The Anti-Atlas samples were exhumed from the late Early Cretaceous to the presentday, starting around the beginning of plate convergence between the Eurasian and African plates. The exhumation first occurred in the centre of the belt and reached the edges during the Late Cretaceous. The western and central Anti-Atlas parts were sourcing sediments deposited in the north Tarfaya Basin during the Neogene. 
Contributions: Mohamed Gouiza collected the samples, completed the analyses, and performed the numerical modelling. I performed similar numerical modelling in an earlier stage of this study and participated with the interpretation of LTT ages and t-T modelling results. All co-authors of the journal article participated in the interpretation of the results.

Acknowledgements: Mohamed Gouiza is thanked for leading this work. Kevin Bisdom is thanked for proofreading this chapter. Pierre-Olivier Bruna and Baptiste Lepillier are thanked for proofreading the figures and tables. Max Holicki is thanked for designing the Latex code used to nicely plot the t-T curves. Geoffrey Ruiz and Rémi Leprêtre are thanked for the LTT discussions. 



\section{4 \\ A quantitative study of Post- Variscan vertical movements in Morocco}

Abstract: We use t-T modelling results from Morocco and its surroundings to define and quantify exhumation events from the Permian to the Neogene. High denudation rates comparable to values typical of rift flank, domal or structural uplifts are only obtained in the Anti-Atlas ( $0.1 \mathrm{~km} / \mathrm{Myr}$ ) during the Early to Middle Jurassic and in the High Atlas (0.1 $\mathrm{km} / \mathrm{Myr}$ ) and Rif (up to $0.5 \mathrm{~km} / \mathrm{Myr}$ ) during the Neogene. Exhumation rates for other periods in the Meseta, High-Atlas, Anti-Atlas, and Reguibat shield are around $0.04 \pm 0.02$ $\mathrm{km} / \mathrm{Myr}$. We then present a series of exhumation maps from which we extract erosion patterns and volumes. Estimates of eroded volumes from Permian onwards are between ca. $15 \times 10^{5}$ and $2 \times 10^{5} \mathrm{~km}^{3}$ in the Reguibat Shield and Meseta, respectively. Periods of high production of sediments in the investigated source areas are the Permian, the Jurassic, the Early Cretaceous (Berriasian to Barremian), and the Neogene.

* Parts of this chapter will be submitted to Basin research: Charton, R., Bertotti, G., Storms, J.E.A., and Redfern, J., to be submitted. Exhumation rates and volumes of eroded material linked to the Post-Variscan vertical movements in Morocco and surroundings. 


\subsection{Introduction}

Continental passive margins, especially in the Atlantic realm, are the locus of a significant amount of studies that evidenced unpredicted pre-, syn-, and post-rift episodic km-scale upward (exhumation) and downward (subsidence) movements (e.g. Green et al., 2018). These events occur in regions characterised by both stretched and non-stretched lithosphere, demonstrating that other processes, extrinsic to the rifting, are at work. Several authors have qualitatively tested these vertical movements with numerical models (e.g. Leroy et al., 2008; Gouiza, 2011; Yamato et al., 2013), but to better constrain these models we still lack a quantification of these movements over geological time and at a large scale.

Low-Temperature Thermochronology (LTT) and time-Temperature (t-T) modelling studies conducted in Morocco and surroundings document $\mathrm{km}$-scale vertical movements, occurring in the period between the Variscan and Atlas orogenies ${ }^{*}$. The Central Atlantic rifting occurred between the Late Triassic and the Early Jurassic (e.g. Labails et al., 2010). Consequently, the documented vertical movements are labelled as pre-, syn-, and post-rift km-scale exhumation and subsidence episodes. Because the LTT data record the cooling of rock samples, they are linked to thermal relaxation or erosion (or denudation; e.g. Pagel, 2014). Hence, LTT ages are observed shortly after magmatism events, during/after processes linked to the creation of topography (e.g. orogenies, shoulder uplift, thermal doming), and/or during processes enhancing erosion (e.g. climatic and sea level changes).

In Morocco, the large majority of the LTT ages were described as resulting from "unexpected" vertical movements and remain to-date enigmatic (e.g. Ghorbal et al., 2008). The t-T modelling studies using the produced ages as inputs have failed to reconstruct a unique time-constrained geological history for the Phanerozoic at the scale of the Moroccan passive margin. Instead authors obtained contemporary opposite vertical movements in neighbouring areas. This is the case for instance of the Anti-Atlas and High Atlas/Meseta massifs, which were source areas at different times for the terrestrial material delivered to coastal basins (e.g. Gouiza et al., 2017a).

Moreover, the west Moroccan offshore Mesozoic basins have potential petroleum systems (Davison, 2005), however, to date hydrocarbon exploration has mostly been unsuccessful. To address this, post-Variscan and pre-Atlas orogenies source-to-sink systems need to be better defined and quantified.

* Please note that the introduction of this Thesis (chapter 1 ) includes the geological history of Morocco. 
In this chapter, we quantify the pre-, syn-, and post-rift km-scale vertical movements occurring since the end of Variscan in Morocco and surroundings. First, we digitize all available $\mathrm{t}-\mathrm{T}$ modelling results. We then convert these thermal evolutions to vertical movements with geologically-constrained geotherms (temperature to depth conversion). This allows calculations of denudation rates for seven periods, which are presented in a series of interpolated contour maps. Finally, we extract the volumes of eroded material and compare them to estimations of deposited sediments along the rifted margin of Morocco.

\subsection{Vertical movement databases}

\subsubsection{LTT database}

Low-Temperature Thermochronology (LTT) is a set of widely used chronothermometers, which allow for the reconstruction of the cooling history of apatite and/or zircon bearing rocks (e.g. Green et al., 1986; Farley, 2000). In Morocco and its surroundings, at least 31 LTT studies were conducted and published (or submitted) in the last 25 years (table 4.1). This allows for the development of an extensive database of 529 (U-Th)/He ages from apatite crystals (AHe) out of 150 samples, 312 Apatite Fission Track (AFT) ages, 225 (U-Th)/He ages from zircon crystals (ZHe) out of 66 samples, and 59 Zircon Fission Track (ZFT) ages. The spatial distribution of the samples (fig. 4.1) highly depends on the lithology of considered areas, as rock samples must contain either apatite or zircon crystals. For this reason, only Precambrian crystalline basement rocks, meta-psammites within the otherwise marine meta-pellite dominated Palaeozoic column, Meso-Cenozoic clastic sediments, and dykes/sills of all ages could be analysed for LTT in Morocco.

Produced AHe, AFT, ZHe, and ZFT ages (table 4.1) are between 0 and $396 \mathrm{Ma}, 0$ and 497 $\mathrm{Ma}, 18$ and $1195 \mathrm{Ma}$, and 18.6 and $585 \mathrm{Ma}$, respectively (null ages were produced from borehole samples). The analysed samples for fission tracks offer one pool- or centralage, whereas for the (He-U)/Th system up to ten ages are produced for each considered samples. For the latter system, a median age is calculated. Median AHe ages are between 0 and $283 \mathrm{Ma}$ and median ZHe ages are between 18.5 and $979 \mathrm{Ma}$ (table 4.1). 
Chapter 4

\begin{tabular}{|c|c|c|c|c|c|c|c|c|c|}
\hline & Locations & References & $\begin{array}{c}\text { Stratigraphic age } \\
\text { of sample }\end{array}$ & $\begin{array}{r}\text { AHe }[\mathrm{Ma}] \\
(\mathrm{a} / \mathrm{n}) \\
\end{array}$ & $\begin{array}{r}\text { AFT [Ma] } \\
(n) \\
\end{array}$ & $\begin{array}{r}\text { ZHe }[\mathrm{Ma}] \\
(\mathrm{a} / \mathrm{n}) \\
\end{array}$ & $\begin{array}{r}\text { ZFT [Ma] } \\
(\mathrm{n}) \\
\end{array}$ & $\begin{array}{l}\mathrm{t}-\mathrm{T} \\
(\mathrm{n}) \\
\end{array}$ & $\begin{array}{c}\mathrm{t}-\mathrm{T} \text { modelling } \\
\text { Software }\end{array}$ \\
\hline \multirow{3}{*}{ 岕 } & Ketama/ Flysch zones & $\begin{array}{c}\text { Azdimousa et al. , } \\
1998\end{array}$ & Meso. & - & $\begin{array}{r}13-20 \\
(5)\end{array}$ & - & $\begin{array}{r}4 \text { failed } \chi \\
\text { test }\end{array}$ & - & - \\
\hline & \multirow{2}{*}{ Internal Zone } & $\begin{array}{c}\text { Azdimousa et al., } \\
2013\end{array}$ & Pal. & - & $\begin{array}{r}14-17 \\
(13)\end{array}$ & - & $\begin{array}{l}19 \\
(4)\end{array}$ & 2 & HeFTy \\
\hline & & Romagny et al. , 2014 & Pal. & $\begin{array}{r}7-21 \\
(45 / 11) \\
\end{array}$ & - & - & - & 2 & QTQt \\
\hline \multicolumn{2}{|c|}{ Canary Islands (Spain) } & Wipf et al., 2010 & Meso.-Ceno. & $\begin{array}{r}15-20 \\
(6 / 2) \\
\end{array}$ & $\begin{array}{r}15-46 \\
(3) \\
\end{array}$ & $\begin{array}{r}13-21 \\
(6 / 3) \\
\end{array}$ & $\begin{array}{r}50-59 \\
(3) \\
\end{array}$ & - & - \\
\hline \multirow{2}{*}{\multicolumn{2}{|c|}{ Eastern Meseta }} & Barbero et al., 2007* & Pal. & - & $\begin{array}{r}270 \\
(1)\end{array}$ & - & - & 1 & AFT-Solve \\
\hline & & El Haimer, 2014* & Pal. & - & $\begin{array}{r}174-198 \\
(2) \\
\end{array}$ & - & - & - & - \\
\hline \multirow{9}{*}{ 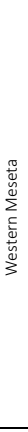 } & \multirow{2}{*}{ Central Massif } & Ghorbal et al. , 2008* & Pal. & $\begin{array}{r}51-243 \\
(9 / 3)\end{array}$ & $\begin{array}{r}148 \\
(1)\end{array}$ & - & - & 1 & HeFTy \\
\hline & & Barbero et al., 2011 & Pal. & - & $\begin{array}{r}202-239 \\
(7) \\
\end{array}$ & - & - & 5 & HeFTy \\
\hline & \multirow{3}{*}{ Rehamna } & Sabbil, 1995 & Pal. & - & $\begin{array}{r}81-113 \\
(21)\end{array}$ & - & $\begin{array}{r}185-228 \\
(6)\end{array}$ & 4 & $\begin{array}{l}\text { Gallagher et al. } \\
\text { (1993) model }\end{array}$ \\
\hline & & Ghorbal et al. , 2008* & Pal. & $\begin{array}{r}15-253 \\
(21 / 6)\end{array}$ & $\begin{array}{r}143-147 \\
(3)\end{array}$ & $\cdot$ & 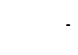 & 3 & HeFTy \\
\hline & & Saddiqi et al. , 2009* & Pal. & - & $\begin{array}{r}148-153 \\
(4) \\
\end{array}$ & - & - & 2 & AFT-Solve \\
\hline & \multirow{4}{*}{ Jebilets } & Mansour, 1991 & PE-Pal. & $\cdot$ & $\begin{array}{r}170-218 \\
(7)\end{array}$ & - & - & - & - \\
\hline & & Ghorbal, 2009* & Pal. & $\begin{array}{l}14-70 \\
(16 / 4)\end{array}$ & $\begin{array}{r}155-163 \\
(3)\end{array}$ & $\cdot$ & - & 3 & HeFTy \\
\hline & & Saddiqi et al. , 2009* & Pal. & - & $\begin{array}{r}186-203 \\
(6)\end{array}$ & $\cdot$ & - & 2 & AFT-Solve \\
\hline & & El Haimer, 2014* & PE-Pal. & $\cdot$ & 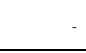 & - & $\begin{array}{r}276-313 \\
(5) \\
\end{array}$ & - & - \\
\hline \multirow{11}{*}{ 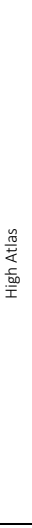 } & Central High Atlas & Barbero et al. , 2007* & Meso.-Ceno. & $\begin{array}{r}25-135 \\
(6 / 3) \\
\end{array}$ & $\begin{array}{r}76-242 \\
(6) \\
\end{array}$ & - & $\cdot$ & 2 & AFT-Solve \\
\hline & Skoura Massif & Barbero et al., 2007* & Pal. & $\cdot$ & $\begin{array}{r}143 \\
(1) \\
\end{array}$ & - & - & - & - \\
\hline & \multirow{2}{*}{ Northern Sub-Atlas } & Ghorbal, 2009* & Pal.-Meso. & $\begin{array}{r}14-141 \\
(18 / 4)\end{array}$ & $\begin{array}{r}142-153 \\
(2)\end{array}$ & - & - & 2 & HeFTy \\
\hline & & $\begin{array}{l}\text { Balestrieri et al ." } \\
2009 *\end{array}$ & Meso. & - & $\begin{array}{r}72-185 \\
(2) \\
\end{array}$ & $\cdot$ & - & - & - \\
\hline & \multirow{5}{*}{$\begin{array}{c}\text { Eastern Precambrian } \\
\text { MAM (Toubkal/ } \\
\text { Oukaimeden) }\end{array}$} & $\begin{array}{c}\text { Missenard et al ., } \\
\text { 2008* }\end{array}$ & $P \in$ & $\cdot$ & $\begin{array}{r}9-27 \\
(10)\end{array}$ & $\cdot$ & - & - & - \\
\hline & & Ghorbal, 2009* & $P \in$ & $\begin{array}{r}9-125 \\
(64 / 17)\end{array}$ & $\begin{array}{r}9-134 \\
(17)\end{array}$ & - & - & 14 & HeFTy \\
\hline & & $\begin{array}{l}\text { Balestrieri et al ., } \\
\text { 2009* }\end{array}$ & PE-Pal.- Meso. & - & $\begin{array}{r}20-86 \\
(4)\end{array}$ & - & - & - & - \\
\hline & & El Haimer, 2014* & $P E$ & $\begin{array}{r}6-12 \\
(6 / 2)\end{array}$ & - & $\cdot$ & - & - & - \\
\hline & & $\begin{array}{c}\text { Domenech } \\
\text { Verdaguer, 2015* }\end{array}$ & $P E$ & $\begin{array}{r}3-11 \\
(33 / 11) \\
\end{array}$ & - & $\begin{array}{r}20-709 \\
(65 / 23) \\
\end{array}$ & - & $3 * * *$ & QTQt \\
\hline & \multirow{2}{*}{$\begin{array}{c}\text { Western Palaeozoic } \\
\text { MAM }\end{array}$} & El Haimer, 2014* & Pal. & $\begin{array}{r}2-9 \\
(8 / 2)\end{array}$ & $\begin{array}{r}65-78 \\
(5)\end{array}$ & - & - & 1 & HeFTy \\
\hline & & $\begin{array}{c}\text { Domenech } \\
\text { Verdaguer, 2015* }\end{array}$ & Pal.-Meso. & - & . & $\begin{array}{r}66-439 \\
(100 / 19) \\
\end{array}$ & - & - & - \\
\hline \multirow{2}{*}{\multicolumn{2}{|c|}{ Anti-Atlas Coastal margin }} & Sehrt, 2014* & Meso. & $\begin{array}{r}63-142 \\
(2 / 1)\end{array}$ & $\begin{array}{r}176-181 \\
(2)\end{array}$ & - & - & 1 & HeFTy \\
\hline & & Charton et al., 2018* & Meso. & $\begin{array}{r}51-140 \\
(5 / 1) \\
\end{array}$ & $\begin{array}{r}214 \\
(1)\end{array}$ & - & - & 1 & HeFTy \\
\hline
\end{tabular}

Table 4.1. LTT and t-T modelling studies carried out in Morocco and neighbouring countries. $t-T$ (n): Number of $t-T$ models. a: Number of aliquots (crystals) and $n$ : Number of rock samples ( $a A H e=529 ; n A H e=150 ; n A F T=312 ; \quad a Z H e=225 ; n Z H e=66 ; n Z F T=59 ;$ total $t-T=117$ ). PE: Precambrian, Pal: Palaeozoic, Meso: Mesozoic, Ceno: Cenozoic. *Studies conducted in several regions (regions as defined here). **AFT ages were digitized from figure 4 a of Martín-Monge et al., 2016. ***Other modelling results are available, but were not preferred in the cited works. 
Exhumation rates \& volumes

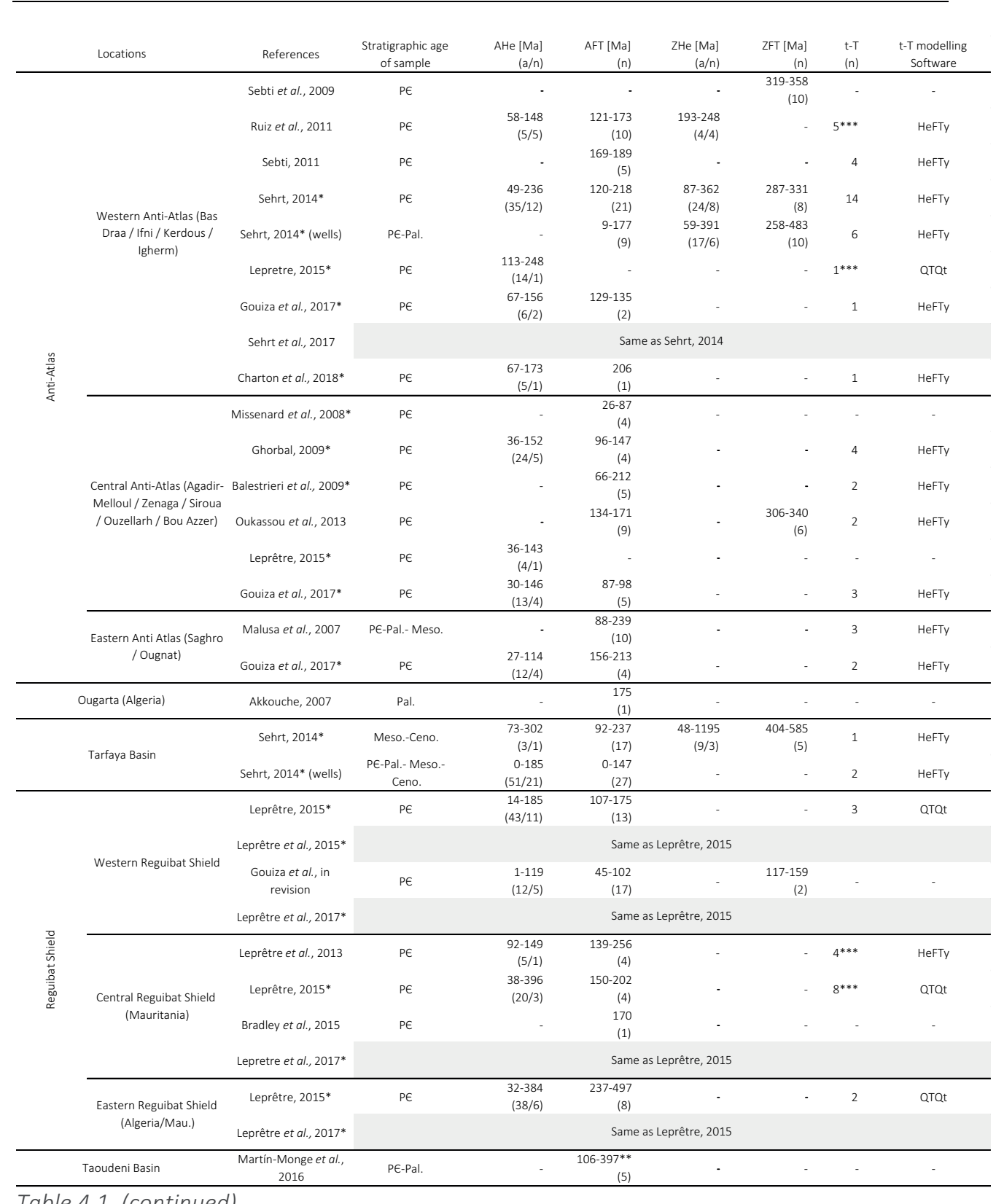




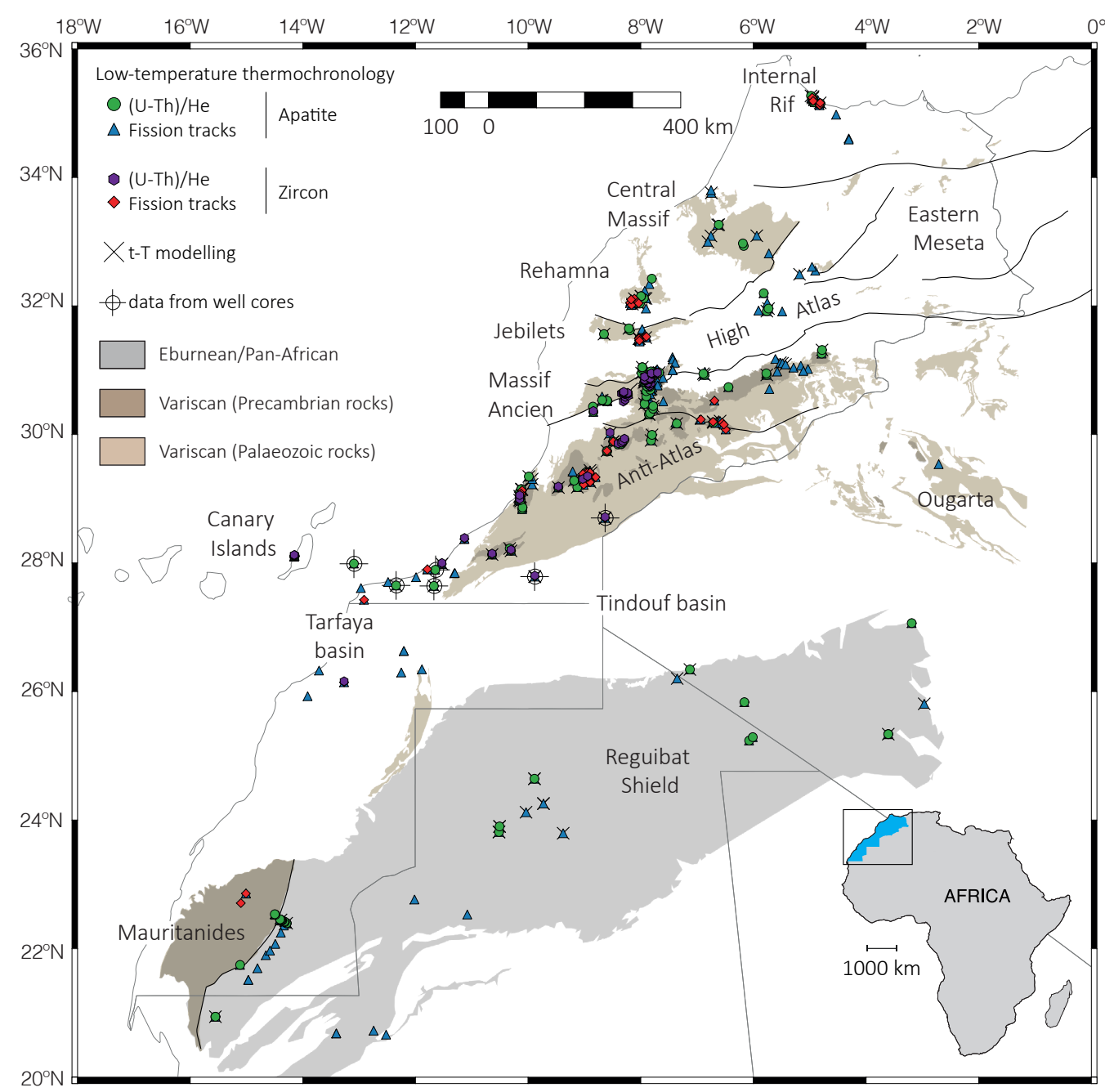

Figure 4.1. Location of LTT samples and t-T modelling (see references in table 4.1).

\subsection{2. $\mathrm{t}-\mathrm{T}$ modelling database}

LTT studies often use the produced cooling ages and fission track density and length as inputs for t-T inverse modelling (e.g. Pagel, 2014). Such modelling allows for testing several $\mathrm{t}-\mathrm{T}$ paths by guiding the model realisations with user-defined constraints. The method provides a comprehensive representation of the $t-T$ path of the analysed sample, highlighting cooling and heating event(s).

From the 31 LTT studies considered in the present study, 22 performed t-T modelling (see appendix for details), resulting in $117 \mathrm{t}$-T models (fig. 4.1). The programs that were used in these studies for the inverse modelling of LTT data are HeFTy (Ketcham, 2005), AFT Solve (Ketcham et al., 2000), and QTQt (Gallagher, 2012). See Vermeesch and Tian (2014) for a comparison of HeFTY and QTQt softwares. The outputs are 'acceptable', 
'good', 'best-fit', and 'weighted average' paths for HeFTy/AFTSolve or 'probability' range, 'maximum likelihood' and 'expected' paths for QTQt. We digitized the weighted average/expected curves when available (fig. 4.2; else the best-fit/maximum likelihood curves) using WebPlotDigitizer* .

The conclusion that was reached in nearly all $\mathrm{t}-\mathrm{T}$ studies was that the considered samples, with cooling ages younger than their stratigraphic ages, recorded vertical movements. This means that cooling and heating events can be translated to exhumation and subsidence, respectively. The exceptions to this general conclusion are the results from samples collected in the Canary Islands (Wipf et al., 2010) and in the Siroua massif (e.g. Ghorbal, 2009), for which a Cenozoic thermal event is assumed to reset the LTT ages.

\subsection{3. $\mathrm{t}-\mathrm{T}$ modelling geological constraints}

The external geological constraints added to t-T modelling between 300 and $0 \mathrm{Ma}$ are reviewed in this section. In the study area, two types of geological constraints are used: 1) where sediments are overlying the sampled basement, a constraint is added at surface temperatures (ca. $10-40^{\circ} \mathrm{C}$ ) for the time of deposition; 2 ) where the age and temperatures of the emplacement or metamorphism of the sampled basement are known, a corresponding constraint is implemented. In the case of detrital thermochronology, the stratigraphic age of the sampled sediments is used as a constraint, which is a similar approach to the first type.

In the Rif belt, Pliocene sediments and Miocene ${ }^{40} \mathrm{Ar} /{ }^{39} \mathrm{Ar}$ and $\mathrm{K}$-Ar radiometric dating were used as geological constraints (Romagny et al., 2014; Azdimousa et al., 2013). In the Meseta, constraints based on the Variscan granite emplacements and Permian, Triassic, and Cenomanian sedimentary records in the basins surroundings the Variscan massifs were added to the t-T modelling (Saddiqi et al., 2009; Ghorbal et al., 2008; Barbero et al., 2011). In the Variscan High Atlas (Massif Ancien), Triassic and poorly dated Early Cretaceous sediments overlying Precambrian basement rocks allowed authors to add related constraints to the models (Ghorbal, 2009; Balestrieri et al 2008; Barbero et al., 2007; Domenech et al., 2016). In the Central Anti-Atlas, emplacement data from the Jurassic intrusive rocks served as a constraint (Barbero et al., 2007). In the Tarfaya basin, Sehrt et al. (2017b) used the Aptian and Albian stratigraphic age of sampled sediments for the t-T modelling.

*Ankit Rohatgi (https://automeris.io/WebPlotDigitizer/) 

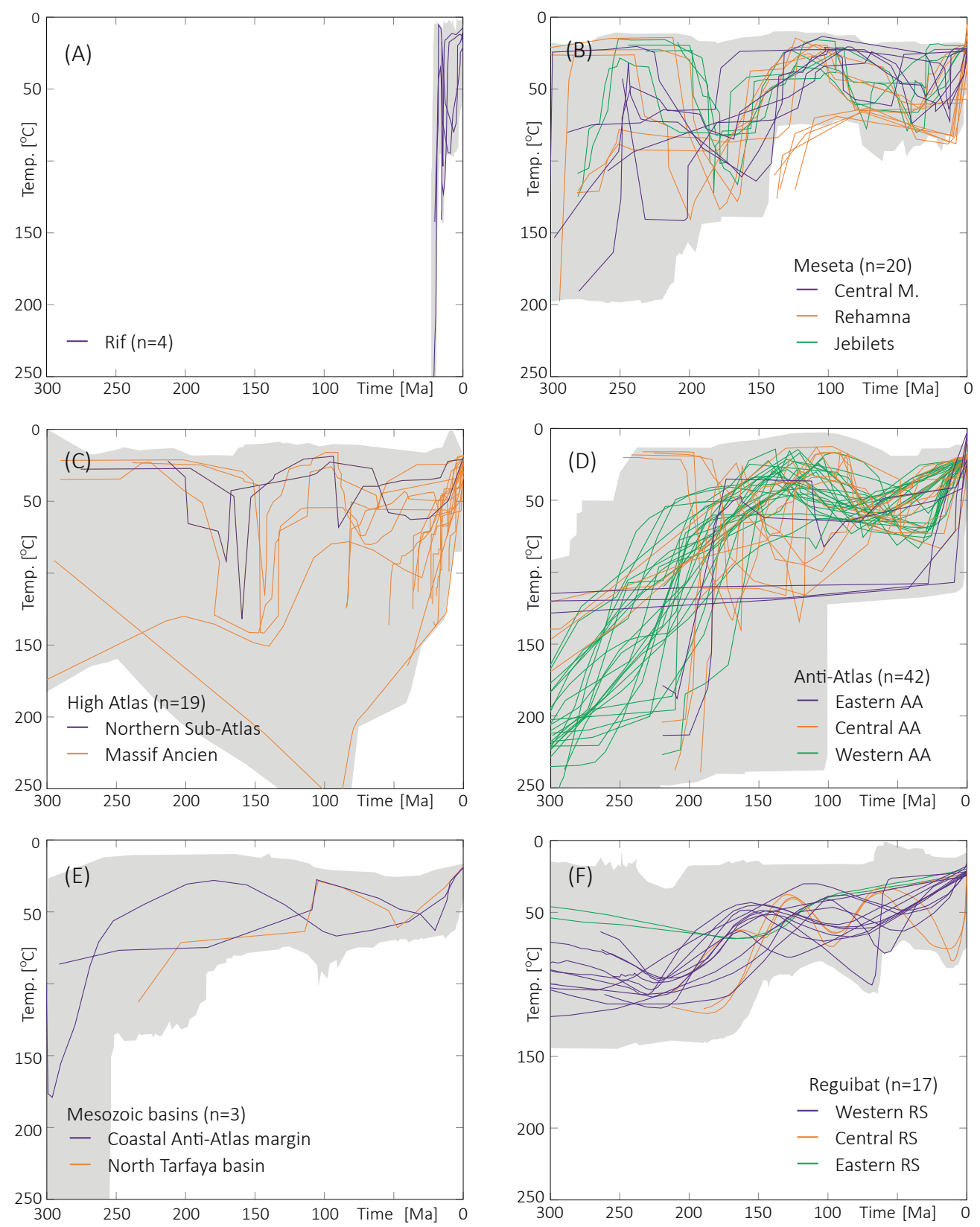

Figure 4.2. Digitized $t-T$ modelling weighted averages, best-fit curves, and acceptable envelops (grey area) for HeFTy results or expected curves, maximum likelihood curves and limits of $2 \sigma$ confidence level (grey area) for QTQt results (see references in table 4.1). $t-T$ results for borehole samples from Sehrt (2014), as well as results from El Haimer (2014) and Barbero et al. (2007), for which only envelopes were published, are not digitized. 
In the Reguibat Shield, a constraint at surface temperatures was defined for the Early/Middle Cretaceous, as sediments (poorly dated) are exposed in the Tarfaya and Tindouf basins (Leprêtre et al., 2013; 2015; 2017). In the eastern Reguibat Shield, the poorly dated Upper Cretaceous sediments of the Reggane basin were used as a constraint (Leprêtre et al., 2017). Overall, these studies used the geological constraints fairly consistently. However, the t-T models of the Anti-Atlas show major discrepancies (Gouiza et al., 2017a; fig. 4.2D). One of the aspects of the modelling, to which these discrepancies can be attributed, is the use of different geological constraints. The Variscan metamorphism (Ruiz et al., 2011; Charton et al., 2018; Malusà et al., 2007) and the emplacement of the CAMP dykes (Gouiza et al., 2017a) were used as constraints. The Triassic sediments in the north of the belt (Ghorbal, 2009), Middle Jurassic sediments (Charton et al., 2018), poorly dated terrestrial Infra-Cenomanian sediments in the western, central, and eastern Anti-Atlas (e.g. Ruiz et al., 2011; Oukassou et al., 2013) and Cenomanian fluvial sediments overlying the Variscan basement on the eastern Anti-Atlas (Gouiza et al., 2017a) were used as evidences of the presently outcropping Anti-Atlas basement rocks being close to surface temperatures.

Despite the classical use of an Early Cretaceous modelling constraint in Morocco, less and less of the Lower Cretaceous terrestrial beds are still considered as such around the Anti-Atlas (reviewed in Gouiza et al., 2017a; Charton et al, 2018). In the eastern part of the belt, the extensive paleontological work conducted by Benyoucef and co-authors showed that the red beds are Cenomanian (e.g. Benyoucef et al., 2015). In the central Anti-Atlas, no recent study on the local undifferentiated clastics has been conducted, but the only time constraint is the Cenomanian limestones positioned above in the stratigraphic column (e.g. Fetah et al., 1990). The clastics could hence be Cenomanian in age, similarly to the eastern Anti-Atlas. Finally, in the western Anti-Atlas, Arantegui (2018) shows with new biostratigraphy control that the local redbeds, also mapped as Lower Cretaceous, are in fact Bathonian (Middle Jurassic) or older. Overall, this invalidates the use of an Early Cretaceous constraint guiding basement rocks of the AntiAtlas close to surface temperatures. In this Thesis, we consider the other modelling constraints used in Anti-Atlas as valid.

\subsection{Exhumation and subsidence rates}

\subsection{1. $\mathrm{t}$-T result selection and depth conversion}

In order to quantify volumes of eroded material on the top of the presently exposed rocks in the study area, we apply a temperature-to-depth conversion. We applied five conditions to select representative and valid t-T curves, resulting in a total of 56 selected $\mathrm{t}-\mathrm{T}$ curves (detailed in table 4.2). We consider that modelling results have to i) start before $20 \mathrm{Ma}$ (about the size of youngest considered period), ii) be based on HeFty, AFT solve or QTQt results, iii) if different models using the same LTT data exist, be from the most recent realizations (e.g. in Leprêtre et al., 2013 and Leprêtre, 2015), iv) should be 
based on one sample and not several as for vertical profiles (justified by the fact that we are interested in punctual measurements), and v) be compatible with the geological history of each region as discussed in the previous part.

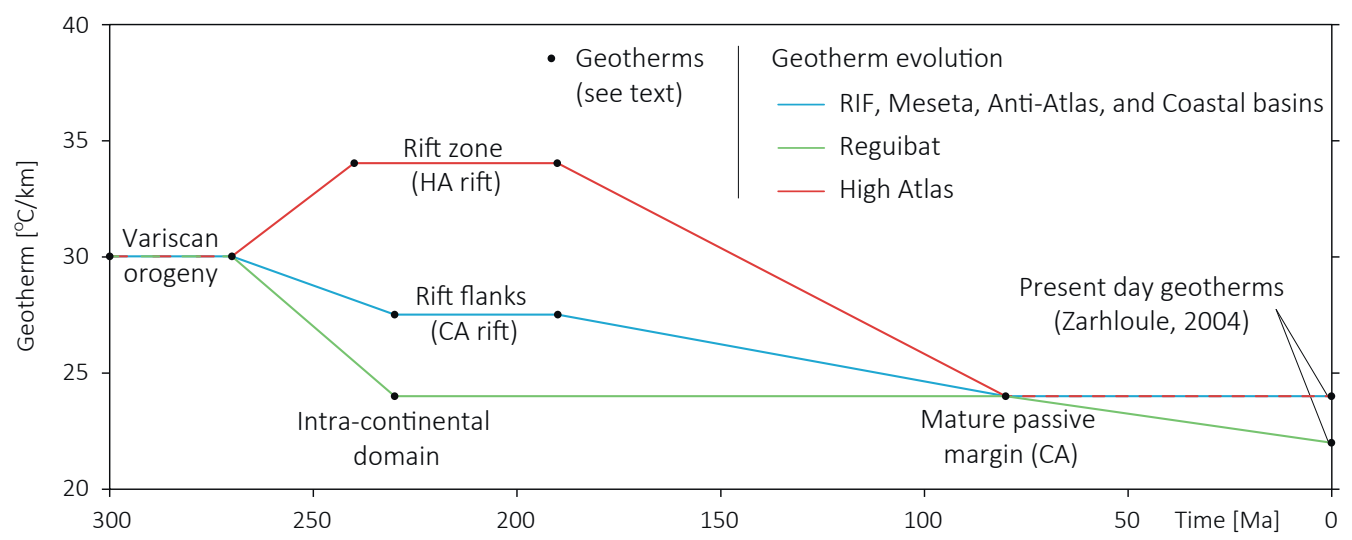

Figure 4.3. Geothermal gradients used for the depth conversion of the $t$ - $T$ curves. Geotherms: Geothermal gradients documented in literature, from present-day or recent settings similar to ones in Moroccan geological past. See description of the geotherms considered as analogues in the text.

To achieve the temperature-to-depth conversion (fig. 4.4), we use three different geotherms based on the location of the selected t-T curves (fig. 4.3) and keep the surface temperature constant at $20^{\circ} \mathrm{C}$. The considered geothermal gradients are based on several studies, which serve as analogue for past geodynamic setting in Morocco. Luth and Willingshofer (2008; after several authors) obtained geothermal gradients of $23-35^{\circ} \mathrm{C} / \mathrm{km}$ for the Alps. According to these values, we considered a geotherm of $29^{\circ} \mathrm{C} / \mathrm{km}$ for the Variscan orogeny. The geotherm in the rift zone of the East African Rift system is ca. $40^{\circ} \mathrm{C} / \mathrm{km}$ (van der Beek et al., 1998) and between 25 and $32^{\circ} \mathrm{C} / \mathrm{km}$ in the Rio Gande Rift (Bridwell, 1976). We consider a geotherm of $34^{\circ} \mathrm{C} / \mathrm{km}$ as representative for the High Atlas Rift zone. The flanks of the East African Rift systems display geothermal gradients between 25 and $30^{\circ} \mathrm{C} / \mathrm{km}$ (van der Beek et al., 1998) and we use $27.5^{\circ} \mathrm{C} / \mathrm{km}$ as an analogue for the Central Atlantic/High Atlas rift flanks. 


\begin{tabular}{|c|c|c|c|c|c|c|c|c|}
\hline $\mathrm{t}-\mathrm{T}$ modelling studies & $\begin{array}{c}t-T \\
(n=117)\end{array}$ & $\begin{array}{r}\text { Fai } \\
\mathrm{i}\end{array}$ & to & eet c & dit & v & $\begin{array}{c}t-D \\
(n=56)\end{array}$ & Comments \\
\hline Sabil, 1995 & 4 & . & 4 & . & . & . & 0 & Program: Gallagher et al, 1993 \\
\hline Barbero et al., 2007 & 3 & & & & & & & $t-T$ : no best-fit or weighted average \\
\hline Malusa et al., 2007 & 3 & . & . & . & . & 3 & 0 & Anti-Atlas: no Mesozoic vertical movements \\
\hline Ghorbal et al., 2008 & 4 & . & . & . & . & . & 4 & All conditions are met \\
\hline Balestrieri et al., 2008 & 2 & . & . & . & . & 2 & 0 & Anti-Atlas: E.Cretaceous exhumation \\
\hline Ghorbal , 2009 & 23 & 1 & . & . & . & 4 & 18 & $t-T$ : younger than 20Ma; Anti-Atlas: E.Cret. exhumation \\
\hline Saddiqi et al., 2009 & 4 & . & . & . & . & . & 4 & All conditions are met \\
\hline Barbero et al., 2011 & 5 & . & . & . & . & . & 5 & All conditions are met \\
\hline Ruiz et al., 2011 & 5 & . & . & . & . & 5 & 0 & Anti-Atlas: E.Cretaceous exhumation \\
\hline Sebti, 2011 & 4 & . & . & . & . & 4 & 0 & Anti-Atlas: E.Cretaceous exhumation \\
\hline Azdimousa et al., 2013 & 2 & 1 & . & . & . & . & 1 & $t-T:$ younger than $20 \mathrm{Ma}$ \\
\hline Lepretre et al., 2013 & 4 & . & . & 4 & . & . & 0 & $t-T:$ corrected models in Lepretre, 2015 \\
\hline Oukassou et al., 2013 & 2 & . & . & . & . & 2 & 0 & Anti-Atlas: E.Cretaceous exhumation \\
\hline ElHaimer, 2014 & 1 & & & & & & & $t-T$ : no best-fit or weighted average \\
\hline Romagny et al., 2014 & 2 & 1 & . & . & . & . & 1 & $t-T$ : younger than $20 \mathrm{Ma}$ \\
\hline Sehrt, 2014 & 24 & . & . & . & . & 14 & 2 & $t-T$ : results from wells; Anti-Atlas: E.Cret. exhumation \\
\hline Domenech, 2015 & 3 & . & . & . & 3 & . & 0 & $t-T:$ modelled for vertical profiles \\
\hline Lepretre, 2015 & 14 & . & . & . & . & 1 & 13 & Anti-Atlas: E.Cretaceous exhumation \\
\hline Gouiza et al., 2017 & 6 & . & . & . & . & . & 6 & All conditions are met \\
\hline Charton et al., in press & 2 & . & . & . & . & . & 2 & All conditions are met \\
\hline
\end{tabular}

Table 4.2. Selection of $t-T(t-T)$ models for temperature-to-depth conversion and for exhumation and subsidence rate calculations. Conditions: The $t-T$ modelling results had to i) start before 20Ma, ii) be based on HeFty, AFT solve or QTQt results, iii) for different models based on the same LTT data, be from the most recent and published realisations, iv) should be based on one sample (as opposed to vertical profiles), and v) be compatible with the geological evidences discussed in the text.

Lastly, Zarhloule (2004) obtained present-day values from Moroccan Passive margin of 20 to $35^{\circ} \mathrm{C} / \mathrm{km}$. As an analogue for the post-rift Moroccan passive margin at $80 \mathrm{Ma}$ (mature passive margin) and for intra-continental domain of the Reguibat Shield, we considered a geotherm of $24^{\circ} \mathrm{C} / \mathrm{km}$. The selected geotherms take into account the thermal relaxation that follows after the rift-related heating phase.

To quantify a depth range in the temperature-to-depth conversion, we used two constant geotherms of 20 and $40^{\circ} \mathrm{C} / \mathrm{km}$. Both values are realistic, given the present day values of geothermal gradients in Morocco and of the used analogues. The low and high constant geotherms applied to the digitized temperature ranges yield the maximum and minimum depths, respectively (dashed lines; fig. 4.4). 

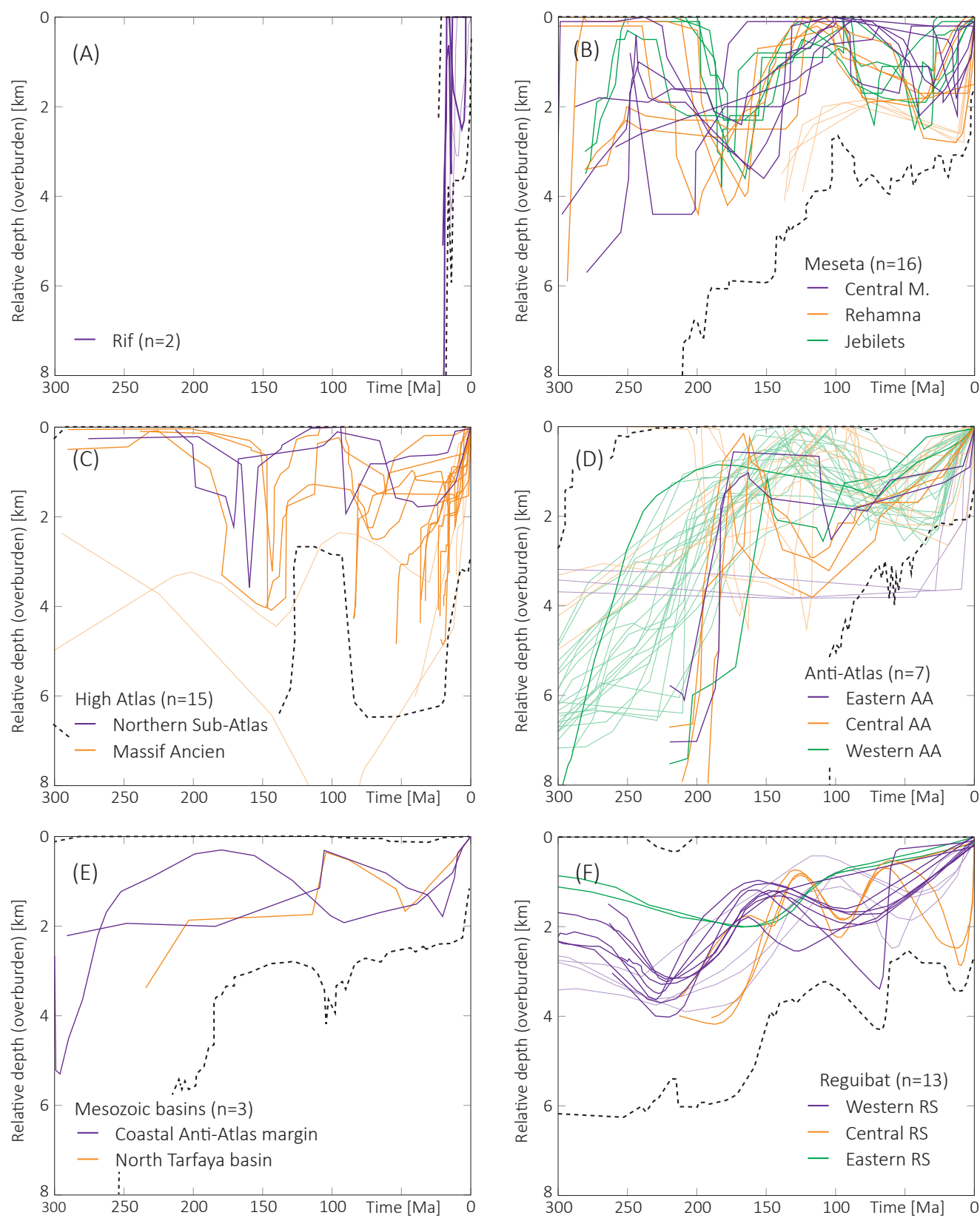

Figure 4.4. Time-depth curves converted from t-T curves shown in figure 4.2, assuming the geothermal gradient evolving as on figure 4.3 and assuming a surface temperature of $20^{\circ} \mathrm{C}$. The bold lines are used for vertical movement rates calculations; non-selected curves in the background were also converted to depth; conditions for selection are in table 4.2. The upper and lower limits (thick dashed lines) are calculated with a geotherm of 40 and $20^{\circ} \mathrm{C} / \mathrm{km}$, respectively. 


\subsubsection{Vertical movement rates}

The vertical movements and their rates documented by the analyzed samples can be quantified from the depth-converted curves (fig. 4.4). Thus, exhumation and subsidence rates $(\mathrm{km} / \mathrm{Myr})$ were calculated. We define seven periods of time for these calculations (periods $a$ to $g$ ), resulting in seven vertical movement rates for each curves (figs. 4.5 and 4.6): Permian ( $a$; 299-252Ma), Triassic ( $b$; 252-201Ma), Early to Middle Jurassic ( $c$; 201$163 \mathrm{Ma})$, Late Jurassic to Early Cretaceous ( $d ; 163-125 \mathrm{Ma})$, Cretaceous ( $\boldsymbol{e} ; 125-66 \mathrm{Ma})$, Palaeogene $(f ; 66-23 \mathrm{Ma})$, and Neogene $(g ; 23-0 \mathrm{Ma})$. The calculated subsidence and exhumation rates range from -0.09 to $0.49 \mathrm{~km} / \mathrm{Myr}$. Figures 4.5 and 4.6 show the calculated motion rates with a spatial or temporal horizontal axes, respectively. In the following, we describe the evolution of the rates as illustrated by figure 4.5 .

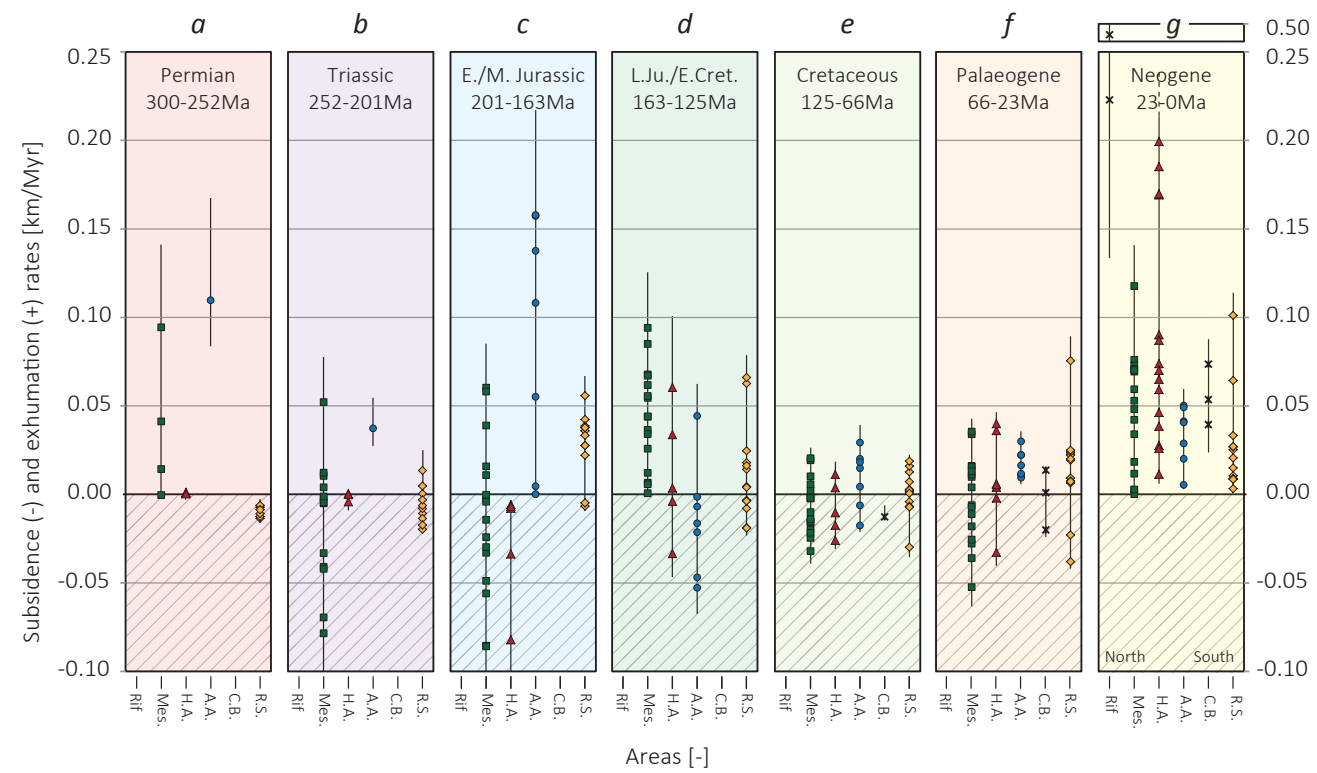

Figure 4.5. Exhumation and subsidence rates calculated from the 56 selected depth converted curves of figure 4.4 using the variable geotherms shown in figure 4.3. The seven defined periods a to $\mathrm{g}$ span between 300 and $\mathrm{O} \mathrm{Ma}$. The combined error bars are extracted from the results of rate calculations using a constant geotherm of $20^{\circ} \mathrm{C} / \mathrm{km}$ and a surface temperature of $20^{\circ} \mathrm{C}$. Mes: Meseta; HA: High Atlas; AA: Anti-Atlas; CB: Coastal Mesozoic basins; RS: Reguibat Shield. North and South are only marked for period $\mathbf{g}$ because Morocco has been significantly rotated since the Permian (e.g. Scotese, 2012).

During the Permian (period $a$ ), sampled basements in the Meseta and the Anti-Atlas were strongly exhumed ( 0 to $0.12 \mathrm{~km} / \mathrm{Myr}$ ), while those of the Reguibat Shield were stable (ca. $-0.01 \mathrm{~km} / \mathrm{Myr}$ ). During the Triassic (period $\boldsymbol{b}$ ), the exhumation in the Meseta and the Anti-Atlas slows down (0.01 to $0.05 \mathrm{~km} / \mathrm{Myr}$ ). The High Atlas and most of the Meseta and Reguibat samples are subsiding (0 to $-0.08 \mathrm{~km} / \mathrm{Myr}$ ). In the Early to Middle Jurassic (period $c$ ), the presently exposed Variscan rocks of the Anti-Atlas are greatly exhumed ( 0 to $0.16 \mathrm{~km} / \mathrm{Myr}$ ). For this region, we observe an acceleration of the 
exhumation from the Triassic to the Jurassic with the highest rates recorded in the Mesozoic. Concomitantly, the surrounding massifs of the Anti-Atlas were mostly subsiding in the north ( 0 to $-0.09 \mathrm{~km} / \mathrm{Myr}$ ), and mildly exhuming in the south ( 0 to 0.06 $\mathrm{km} / \mathrm{Myr}$ ). The Late Jurassic to Early Cretaceous period $(\boldsymbol{d})$ is marked by the subsidence of the Anti-Atlas ( 0 to $-0.05 \mathrm{~km} / \mathrm{Myr}$ ), whereas the sampled basement of the Meseta, the Reguibat shield, and the High Atlas to some extent, were exhuming (0 to 0.09 $\mathrm{km} / \mathrm{Myr}$ ). During the Cretaceous (period $\boldsymbol{e}$ ), the exhumation in the Meseta, the High Atlas, and the Reguibat Shield regions slows down, and all areas are rather stable (weak exhumation and subsidence) with motion rates between ca. 0.03 and $-0.03 \mathrm{~km} / \mathrm{Myr}$. The exhumation is renewed in the Anti-Atlas during the Palaeogene (period $f ; 0.01$ to 0.03 $\mathrm{km} / \mathrm{Myr}$ ), while other areas remain characterised by exhuming and subsiding domains. Finally, the Neogene $(\mathbf{g})$ period was characterised by exhumation with a significant acceleration trend; generally, below $0.10 \mathrm{~km} / \mathrm{Myr}$, they reach $0.20 \mathrm{~km} / \mathrm{Myr}$ in the High Atlas and $0.49 \mathrm{~km} /$ Myr in the Rif belt.

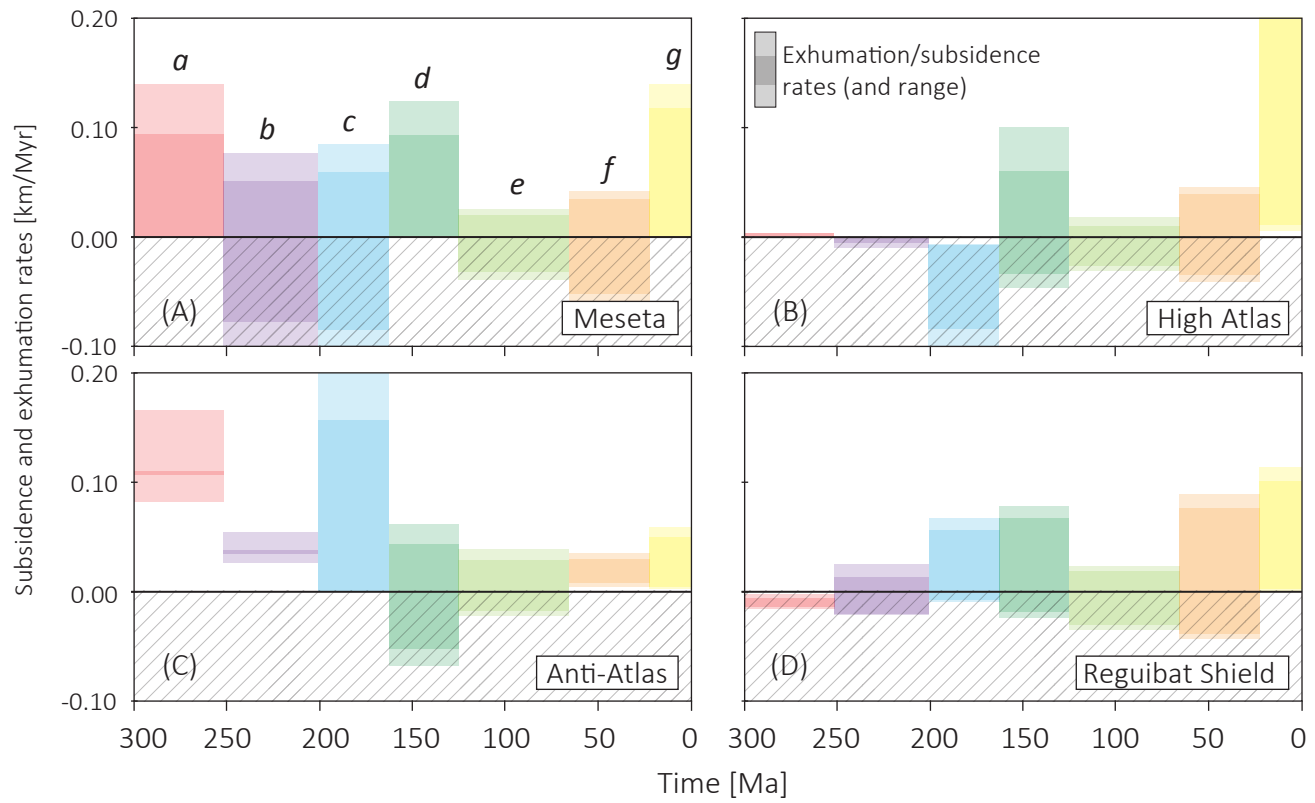

Figure 4.6. Evolution of the calculated exhumation and subsidence rates of basement rocks for the last $300 \mathrm{Ma}$ in the A) Meseta, B) High Atlas, C) Anti-Atlas, and D) Reguibat Shield. Periods as defined in the text and rates as presented in figure 4.5. 


\subsection{Exhumation maps and eroded material fluxes}

In the following section, we estimate the volumes of material that have been removed through time. We first build seven exhumation maps (fig. 4.8), using the calculated subsidence/exhumation rates as recorded by LTT. We also take into account simplified stratigraphy columns of the Permian to Neogene onshore and offshore basins in the study area (fig. 4.7). We then calculate volumes of material removed per million years, from these maps for the considered regions of Morocco and surroundings.

\subsubsection{Interpolation of the exhumation rates and limitations}

Data points for of the exhumation maps consist of the exhumation and subsidence rates calculated above with variable geotherms. For the computation of ranges of the volumes, we use rates obtained from the temperature ranges converted to depth with constant geotherms.

We added synthetic points on the basis of the stratigraphy columns, which are compiled in figure 4.7. For each preserved sedimentary basin, up to four points were created. If sediments were deposited during one of the selected periods and are still preserved in a basin, we attribute a rate of $-0.011 \mathrm{~km} / \mathrm{Myr}$ to all the synthetic points of this basin. When sediments are not recorded in a basin, because they were not deposited or not preserved, we attribute to synthetic points a rate of $0 \mathrm{~km} / \mathrm{Myr}$.

The Continental-Ocean Boundary (COB; Miles et al., 2012) is implemented as a line and is used to yield synthetic exhumation/subsidence rates. Before the Jurassic, the COB has not yet been created in Morocco. Nevetheless, for the Permian and Triassic (periods $a$ and $\boldsymbol{b}$ ), we consider a similar position for the line to yield synthetic rates. For the Permian, the COB line is attributed an exhumation rate of $0.1 \mathrm{~km} /$ Myr. This is to account for the collapse (peneplain) of the Variscan chain, which is documented in Morocco between the Carboniferous and the Triassic (e.g. Michard et al., 2008). Exhumation rates during post-orogenic collapses have been used or documented between 0.15 and 0.7 km/Myr (e.g. Clift et al., 2004; Mazzoli et al., 2010; Casini et al., 2015). We consider in this study a lower exhumation rate of $0.1 \mathrm{~km} / \mathrm{Myr}$, comparable to the highest rate we calculated for the Permian (period $a$ ). From Triassic onwards (periods $b$ to $g$ ), we attributed to the COB line a subsidence rate lower than $-0.01 \mathrm{~km} / \mathrm{Myr}(-0.011 \mathrm{~km} / \mathrm{Myr})$. This is equivalent to adding many synthetic points with subsiding rates, as abovedefined, in the slope or basinal domains. 


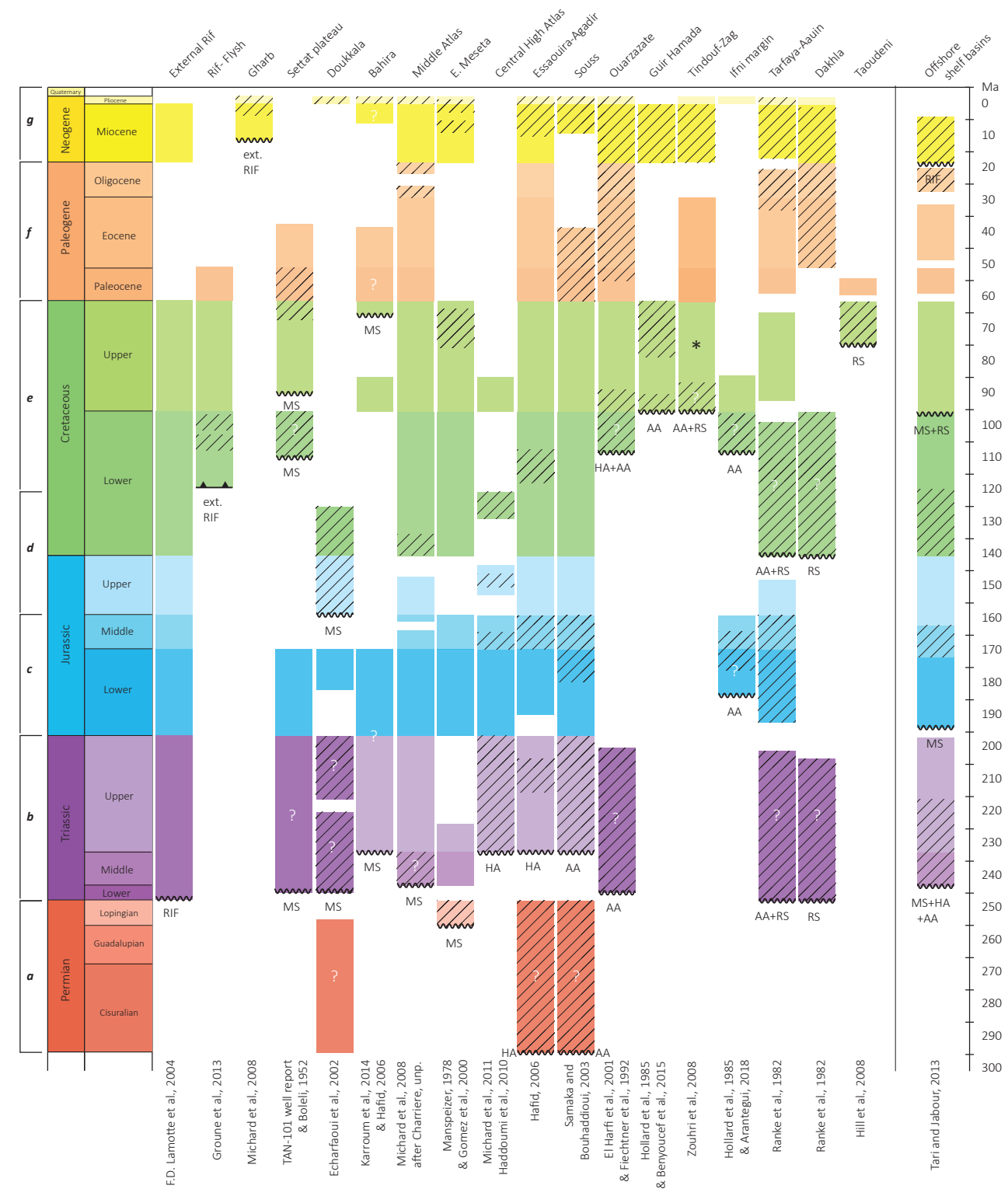

Figure 4.7. Simplified stratigraphic columns. The hatched parts highlight continental facies and/or coarse to very coarse deposits. Below uncoformity surfaces are the name of the corresponding Variscan/Precambrian basement (MS: Meseta, HA: High Atlas, AA: AntiAtlas, and RS: Reguibat shield basements). The seven selected periods (a to g) are shown on the left. *Late Cretaceous in the Tindouf basin is present in the eastern and western parts, but not in its central part (Hollard et al., 1985). 
For the interpolation of the exhumation (and subsidence) rates, we use the nearest neighbour algorithm (available in Surfer version 8; Golden Software, Inc.). This algorithm is simple to implement, its interpolation grid can be extended to the study area completely, and allows for the implementation of faults. The interpolation grid extends from 0 to $-18^{\circ} \mathrm{W}$ and 20 to $36^{\circ} \mathrm{N}$ (112x100 lines with fixed spacing) and ends at the COB in the west. For the Triassic, Palaeogene, and Neogene, the Atlas system faults are added as boundaries.

The Nearest Neighbor is fairly simple, but as such it has some limitations. For instance, this algorithm gives better results with regularly spaced data points. In addition, it does not extrapolate the rates above and below their values. The interpolated rates are calculated from the closest data/synthetic points. When located exactly in the middle between two points, the lowest value will be attributed to the interpolated rates, which is most likely responsible for artefacts observed in the maps (fig. 4.8). These artefacts are expressed as areas with important changes of rates over short distances. 

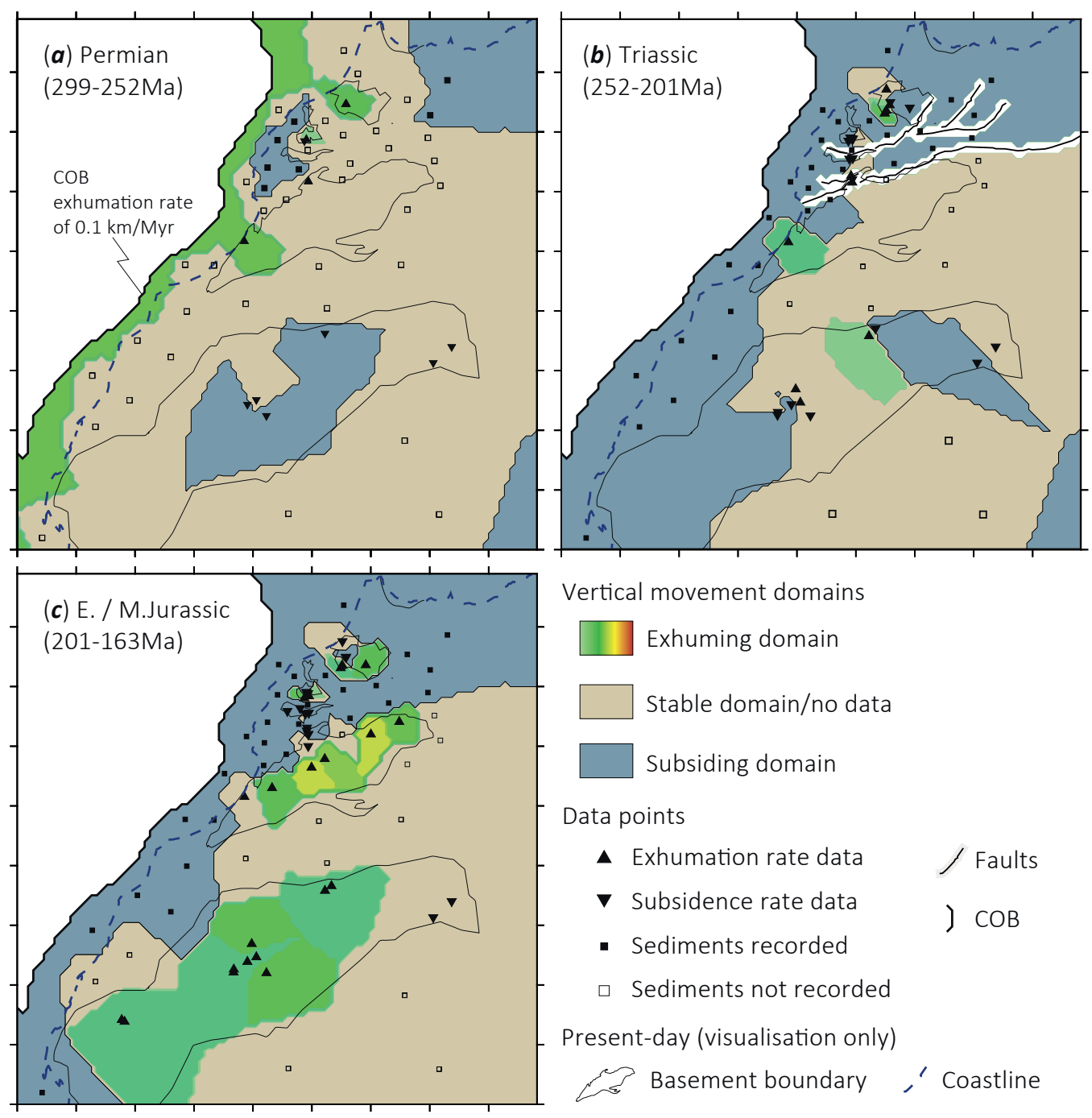

Vertical movement domains

Exhuming domain

$\square$ Stable domain/no data

Subsiding domain

Data points

- Exhumation rate data

$\boldsymbol{\nabla}$ Subsidence rate data

) $\mathrm{COB}$

- Sediments recorded

$\square$ Sediments not recorded

Present-day (visualisation only)

B Basement boundary ,' Coastline

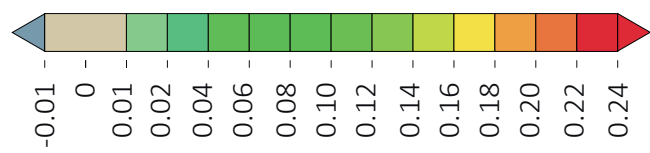

Exhumation rate $[\mathrm{km} / \mathrm{Myr}]$

Figure 4.8. Exhumation maps for the seven selected periods (a-c on this page and $\mathrm{d}-\mathrm{g}$ on the next one) after geological record (fig. 4.7) and vertical movement rates (fig. 4.5). We define three domains in the exhumation maps: a subsiding domain with rates $\leq-0.011 \mathrm{~km} / \mathrm{Myr}$, a stable domain characterised by rates between -0.01 and 0.01 , and an exhuming domain with rates $\geq 0.011 \mathrm{~km} / \mathrm{Myr}$. Note that the western boundary is the Continent-Ocean Boundary $(C O B)$. 

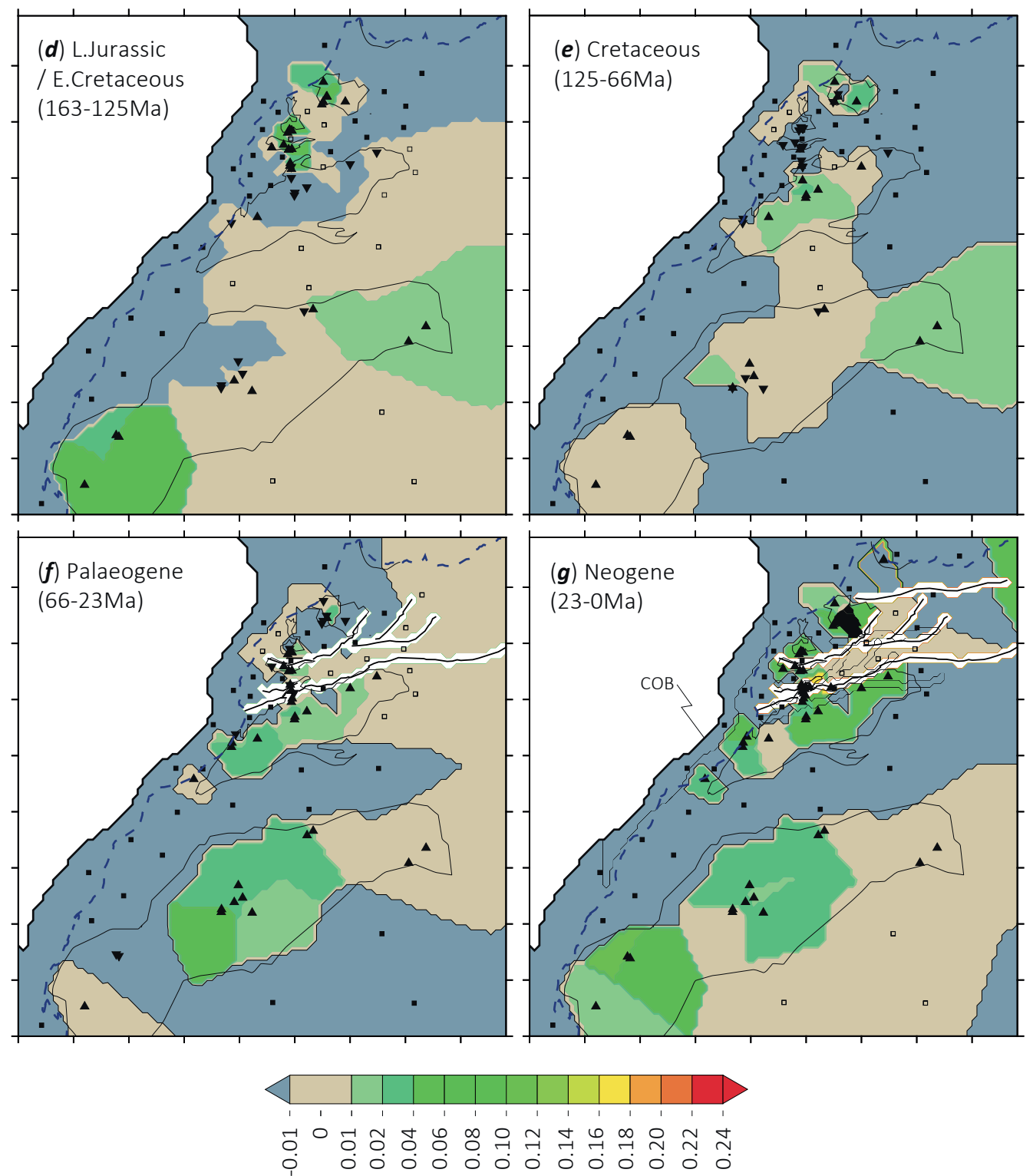

Exhumation rate [km/Myr]

Figure 4.8. (continued) 


\subsubsection{Eroded material fluxes and associated uncertainties}

Volume calculations of eroded material per million years $\left(\mathrm{km}^{3} / \mathrm{Myr}\right.$; eroded material flux) are performed with Surfer software between the interpolated surface and a plane characterised by a null motion rate $(0 \mathrm{~km} / \mathrm{Myr})$. The eroded material fluxes computed here are an estimation of the amount of eroded material per million years, above the samples exposed at the surface today. They are however not sediment fluxes. Indeed, LTT data does not take into account the lithology of the overburden, and hence its erodibility (Flowers and Ehlers, 2018). In other words, the calculated volume of material removed from the source areas will ultimately not be equal to the volume of material deposited in the sink areas. The volumes are calculated for three regions of interest: the Meseta, the High Atlas, the Anti-Atlas, and the Reguibat Shield (table. 4.3).

\begin{tabular}{|c|c|c|c|c|c|c|c|c|}
\hline & & \multicolumn{7}{|c|}{ Periods [-] } \\
\hline & & a & $\mathrm{b}$ & c & d & $\mathrm{e}$ & $f$ & $\mathrm{~g}$ \\
\hline \multirow{6}{*}{$\begin{array}{l}\text { Volume rates } \\
{\left[\mathrm{km}^{3} / \mathrm{Myr}\right]}\end{array}$} & & 21601 & 1804 & 22771 & 15711 & 5480 & 11579 & 28769 \\
\hline & Interpolation Grid & 23653 & 3805 & 29275 & 19355 & 6923 & 14025 & 33463 \\
\hline & & 20686 & 1879 & 14561 & 9623 & 3421 & 6935 & 17020 \\
\hline & Meseta \& High Atlas & 2318 & 115 & 571 & 745 & 180 & 161 & 1304 \\
\hline & Anti-Atlas & 3579 & 675 & 8061 & 1020 & 929 & 1343 & 3030 \\
\hline & Reguibat Shield & 1782 & 588 & 11486 & 8226 & 1583 & 7653 & 10886 \\
\hline Surface area & Exhuming domain & $1.610^{6}$ & $0.910^{6}$ & $1.210^{6}$ & $1.210^{6}$ & $0.610^{6}$ & $1.010^{6}$ & $1.310^{6}$ \\
\hline$\left[\mathrm{km}^{2}\right]$ & Subsiding domain & $0.710^{6}$ & $1.410^{6}$ & $1.110^{6}$ & $1.110^{6}$ & $1.710^{6}$ & $1.310^{6}$ & $1.010^{6}$ \\
\hline
\end{tabular}

Table 4.3. Eroded material fluxes and surface areas from Permian (a) to Neogene (g). The ranges of our results are provided with the presented workflow, but with constant geotherm of $20^{\circ} \mathrm{C} / \mathrm{km}$ * and $40^{\circ} \mathrm{C} / \mathrm{km}^{* *}$. We also estimate the error of our findings between 20 and $10 \%$.

The calculated volumes of eroded material for the seven exhumation maps range from $7.6 \times 10^{5}$ to $0.7 \times 10^{5} \mathrm{~km}^{3}$ for the Jurassic and Triassic, respectively (fig. 4.9 and table 4.3). For the considered regions, the eroded material fluxes are between ca. 600 and 11,000 $\mathrm{km}^{3} / \mathrm{Ma}$ for the Reguibat Shield, ca. 700 and $8,000 \mathrm{~km}^{3} / \mathrm{Ma}$ for the Anti-Atlas, and ca. 100 and 2,300 $\mathrm{km}^{3} /$ Ma for the Meseta and High Atlas massifs (fig. 4.9).

Besides provided ranges for the rates and volumes, we assess the error bar of the presented workflow. LTT analyses in Morocco have typically 10\% error for (U-Th)/He system, while the FT system error depends on the operator, but is also 10\% (estimation made from the dataset gathered in this study). The $t-T$ modelling has a large temporal and thermal uncertainty associated to all realisations (e.g. good and acceptable envelopes for HeFTy) and increases with time (fig. 4.2). Other factors such as the selection of $\mathrm{t}-\mathrm{T}$ modelling curves and geotherms, plus the fact that we assume a constant surface temperature, are impacting the error bar. Another source of uncertainty lies in the use of non-restored base maps for the exhumation maps because extents of some areas are likely to be different (in the High Atlas before the recent orogeny for instance). The use of a null motion rate for the created synthetic points also introduces an error, as non-recorded sediments might have been eroded (i.e. subsidence rate) or never deposited (i.e. null or exhumation rate). Last, the errors associated to the interpolation method and volume calculations are also difficult to 
quantify. Overall, we estimate the error of our method to $20 \%$ for Permian and Mesozoic (periods $a$ to $e$ ) and to $10 \%$ for Palaeogene and Neogene (periods $f$ and $g$ ).

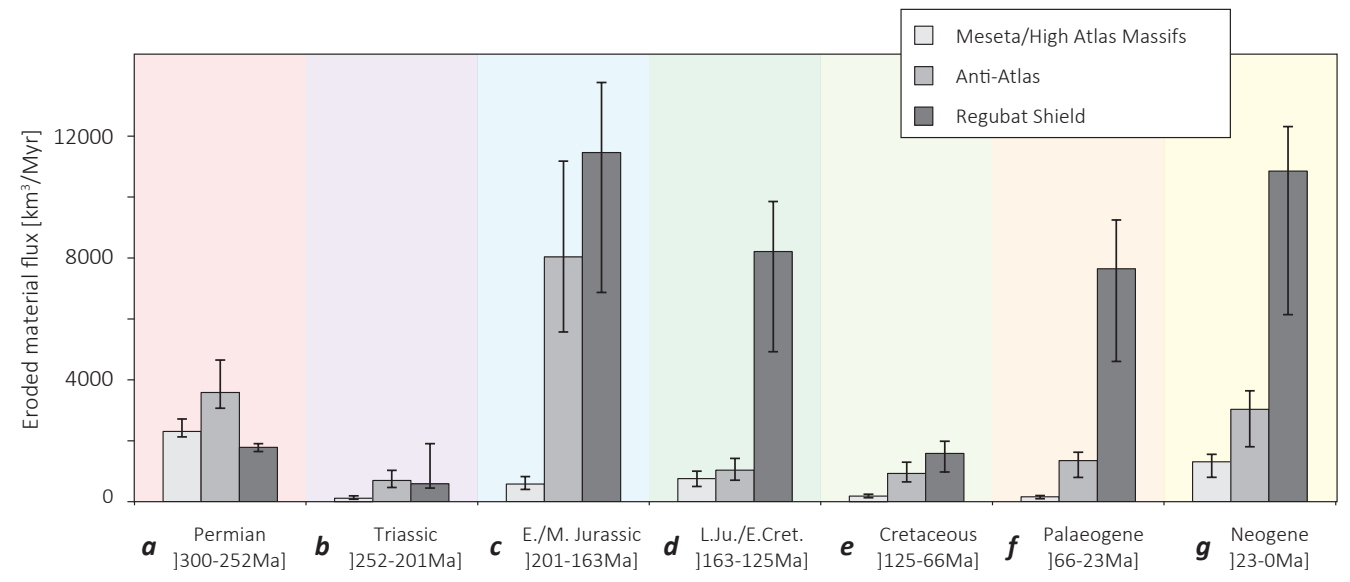

Figure 4.9. Estimated eroded material flux for the three main sediment sources (Meseta/High Atlas, Anti-Atlas, and Reguibat Shield) for the seven defined periods (a-g). The eroded material flux is obtained with variable geotherms (fig. 4.3), while the ranges are given by calculations done with two constant geotherms of 20 and $40^{\circ} \mathrm{C} / \mathrm{km}$. See the text for a estimation of the error bar associated to our workflow.

\subsection{Exhumation and subsidence evolution}

\subsubsection{Phanerozoic exhumation and subsidence patterns}

The exhumation maps (fig. 4.8) show the pattern of erosion in the continental Moroccan margin between the Permian and the present-day. During the Permian (period $a$ ), erosion occurred in the remnants reliefs of the Variscan chain (e.g. Lorenz, 1988; Voigt et al., 2010), located mostly in the Meseta and Western Anti-Atlas. Known Permian basins are the Eastern Meseta, Doukkala and Argana Valley basins. From the interpolated area, we estimate the volume of produced sediments to be about $1.0 \times 10^{6}$ $\mathrm{km}^{3}$, of which only little is preserved today. Subsiding domains predicted by the $\mathrm{t}-\mathrm{T}$ modelling results are the Central and Eastern Reguibat Shield.

During the Triassic (period $\boldsymbol{b}$ ) the northern Meseta (ca. 6,000 $\mathrm{km}^{3}$ ), the Anti-Atlas (ca. $35,000 \mathrm{~km}^{3}$ ), and the Reguibat Shield (ca. $30,000 \mathrm{~km}^{3}$ ) were being eroded. A large portion of the Meseta subsided, which could mean that it was part of the Central Atlantic and/or High Atlas rift zones. According to the stratigraphic columns, most Moroccan basins contain Triassic sediments; except the Tindouf, the Taoudeni, and the Guir Hamada basins. The Central Atlantic and Atlas rift zones were subsiding, except parts of the Massif Ancien. This massif is described as a structural relief sourcing Triassic sediments to the Argana and Oukaimeden valley (e.g. Baudon et al., 2012). The t-T modelling results do not cover the time before $200 \mathrm{Ma}$ in the Central and Eastern AntiAtlas (Gouiza et al., 2017a), but red clastics overlying the Precambrian basement in the 
northern Central Anti-Atlas are mapped as Triassic. There, no recent study on these sediments has been conducted, however, basaltic flows covering them have yielded

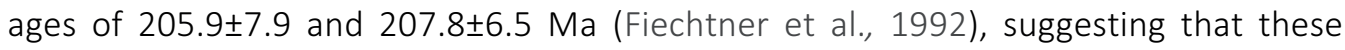
deposits are indeed Triassic. In turns, this means that while the core of the Anti-Atlas was exhuming, its northern counterpart was subsiding (including Souss and Ouarzazate basins).

The Jurassic period (period $c$ ) is marked by enhanced erosion in the Anti-Atlas and Reguibat Shield, and to some extent in the Meseta. We estimate the production of sediment by erosion to be $0.9 \times 10^{6} \mathrm{~km}^{3}$. From the seven selected periods, it is the most active one in terms of eroded material flux for the Anti-Atlas. It is likely that the AntiAtlas was a bulge as exhumation rates are higher in the central part. Middle Jurassic redbeds are recorded in the onshore basins north and west of the Anti-Atlas (Tarfaya, Agadir-Essaouira, Central High Atlas, Ifni Margin, and Souss basins; fig. 4.7). In the basins south and east of the Anti-Atlas, no Jurassic sediments are recognised. This supports the idea of exhuming Anti-Atlas and Reguibat Shield, linked by an exhuming or stable Tindouf area. From the Middle to Late Jurassic, our results show a shift in the areas of sediment production, from the Anti-Atlas to the Meseta.

The exhumation of the Meseta massifs (ca. $750 \mathrm{~km}^{3} / \mathrm{Myr}$ ) from Late Jurassic to Early Cretaceous (period $\boldsymbol{d}$ ) was first described in Ghorbal et al. (2008). The preserved onshore basins of the Meseta do not record Middle/Upper Jurassic sediments, excepted the coastal Doukkala basin. This suggests that a surface larger than that of the presently outcropping basement was being eroded. Although most vertical movement rates are negative in the Anti-Atlas, one is positive in the western part of the belt (fig. 4.8D). This could be due to a t-T modelling inconsistency or it could be a remnant, non-structural, relief from the previous period. A sedimentary provenance study was conducted in the north Tarfafa Basin for lower Cretaceous to Cenozoic sediments (Ali et al., 2014). Their results showed that the Lower Cretaceous sediments were sourced from the Reguibat Shield, while upper Cretaceous sediments were sourced from both the Reguibat Shield and the Anti-Atlas. In turns, it suggests that the one positive vertical movement rate calculated for the western Anti-Atlas is wrong, and that the t-T modelling results for that specific sample are inconsistent. The Reguibat Shield witnessed substantial erosion (ca. $8,200 \mathrm{~km}^{3} / \mathrm{Myr}$ ). It appears that the source area of the sediments deposited in the Boujdour and Tan-Tan deltas is the Reguibat Shield, with over $700,000 \mathrm{~km}^{3}$ of eroded material during the Jurassic/Cretaceous period.

In the late Early to Late Cretaceous period (period $\boldsymbol{e}$ ), subsiding domains are the dominant feature in the study area. This period is characterised by a rise in the sea level (Cenomanian-Turonian transgression; e.g. Piqué et al., 2006), which reached the interior of Morocco and Algeria (e.g. Late Cretaceous deposits in the Guir Hamada; e.g. Benyoucef et al., 2015). It appears to have partially submerged the Reguibat shield, Tindouf basins (except its central part), and the borders of the Anti-Atlas. The Anti-Atlas 
erosion (ca. $900 \mathrm{~km}^{3} / \mathrm{Myr}$ ) starts in its centre, and later extents to the eastern and western regions.

Finally, the Palaeogene and the Neogene (periods $f$ and $g$ ) periods are characterised by the Atlas orogeny, which is expressed by high exhumation rates in the High Atlas, Rif, and also Anti-Atlas and Reguibat Shield. We estimate the volume of eroded material from the studied area during the Palaeogene and Neogene to ca. $0.5 \times 10^{6}$ and $0.7 \times 10^{6}$ $\mathrm{km}^{3}$, respectively.

\subsubsection{Eroded material fluxes vs. sedimentation rates}

We compare the total eroded volume rates to the study of Helm (2009; fig. 4.10). This study considered several segments along the western African margin, including the Moroccan segment. The sedimentation rates in the offshore domain and the coastal basins are obtained from nine interpreted seismic profiles perpendicular to the coast, and extended by extrapolation and/or well control to the basin (using DSDP wells). The obtained volumetric rates, from the Triassic to the Neogene, were then adjusted for sediments with a terrestrial source. It is important to note that the resolution is not identical between the two studies; moreover, the defined periods are also not systematically concordant.

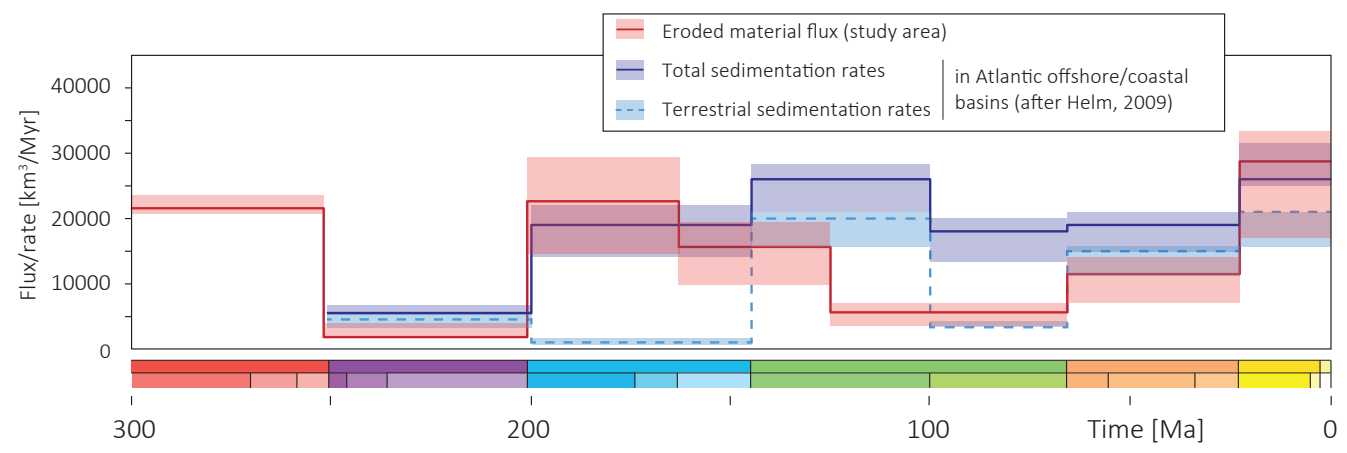

Figure 4.10. Comparison of the total eroded material flux to sedimentation rates in Moroccan offshore and coastal basins (after Helm, 2009).

This comparison shows that the siliciclastic volumes deposited in the offshore/coastal basins and the eroded volume of material from the interpolation grid are of the same order of magnitude (fig. 4.10). Volumes are even similar during the Triassic, early Early Cretaceous, Cretaceous, Palaeogene, and Neogene. It is overall a fairly good match, except for the rates during the Jurassic period. According to our results, between 10,000 to $30,000 \mathrm{~km}^{3} / \mathrm{Myr}$ of material were eroded, while the offshore seems to record about 1000 to $2000 \mathrm{~km}^{3} /$ Myr of siliciclastic sediments. To explain this discrepancy, we make the hypothesis that the erosion, occurring in the Reguibat Shield, Anti-Atlas, Tindouf, and Meseta removed fine-grained and/or carbonated meta-sediments from the top of the Palaeozoic pile. Hence, little coarse terrestrial material would be recorded in the basins, were platform limestones are dominant. 


\subsection{Conclusions}

We have used t-T modelling results from Morocco and its surroundings as a proxy for defining and quantifying exhumation events from the Permian to the present-day. We then presented a series of exhumation maps from which we extracted erosion patterns and volumes. This allowed us to elaborate on the possible responsible mechanism(s) of these vertical movements. The presented findings have implications for the evolution of the Central Atlantic passive margins and for our understanding of the Permian to Neogene Moroccan source-to-sink systems.

The reconstructed evolution of vertical movements and erosion at the scale of the passive margin can be divided into 3 areas: the Reguibat Shield, the Anti-Atlas, the Meseta, and the High Atlas.The Reguibat Shield is marked by subsidence from the Permian to the Triassic, and exhumation from the Jurassic onwards for most of the massif (0.01-0.06 km/Myr; ca. 1,400,000 km ${ }^{3}$ ). We infer that the Reguibat shield was the only source of sediments for the Boujdour and the Tan-Tan Cretaceous deltas, offshore Tarfaya basin.

The sampled Anti-Atlas basement rocks were deeply buried in the Permian and were exhumed between the Triassic and the Middle Jurassic (0.01-0.16 km/Myr; ca. 300,000 $\mathrm{km}^{3}$ ). Subsidence during the Late Jurassic/Early Cretaceous was followed by a final exhumation from the Late Cretaceous onwards (0.01-0.05 km/Myr; ca. 180,000 km³). Moreover, the spatial distribution and the high values of exhumation rates suggest structural or domal uplift in the Early/Middle Jurassic, with higher reliefs in the Central Anti-Atlas.

The presently outcropping Variscan rocks in the Meseta and High Atlas were close to the surface during the Permian/Late Triassic, followed by subsidence until the Middle Jurassic, exhumation in the Late Jurassic/Early Cretaceous (exhumation rates: 0.01$0.09 \mathrm{~km} /$ Myr; eroded material: ca. $28,000 \mathrm{~km}^{3}$ ), renewed subsidence during the Late Cretaceous and a finally exhumation during the Cenozoic (0.01-0.20 km/Myr; ca. 37,000 $\mathrm{km}^{3}$ ). There, the subsidence event synchronous to the rifting brought the samples from close to the surface down to $4 \mathrm{~km}$, suggesting that the Central Atlantic and/or the High Atlas rift zone(s) extended over nearly the entire Meseta. 
Acknowledgements: Max Holicki is thanked for proofreading this chapter and for designing the Latex code used to nicely plot the t-T curves. Pierre-Olivier Bruna is thanked for proofreading the figures and tables. Quinten Boersma is thanked for the geological discussions. 



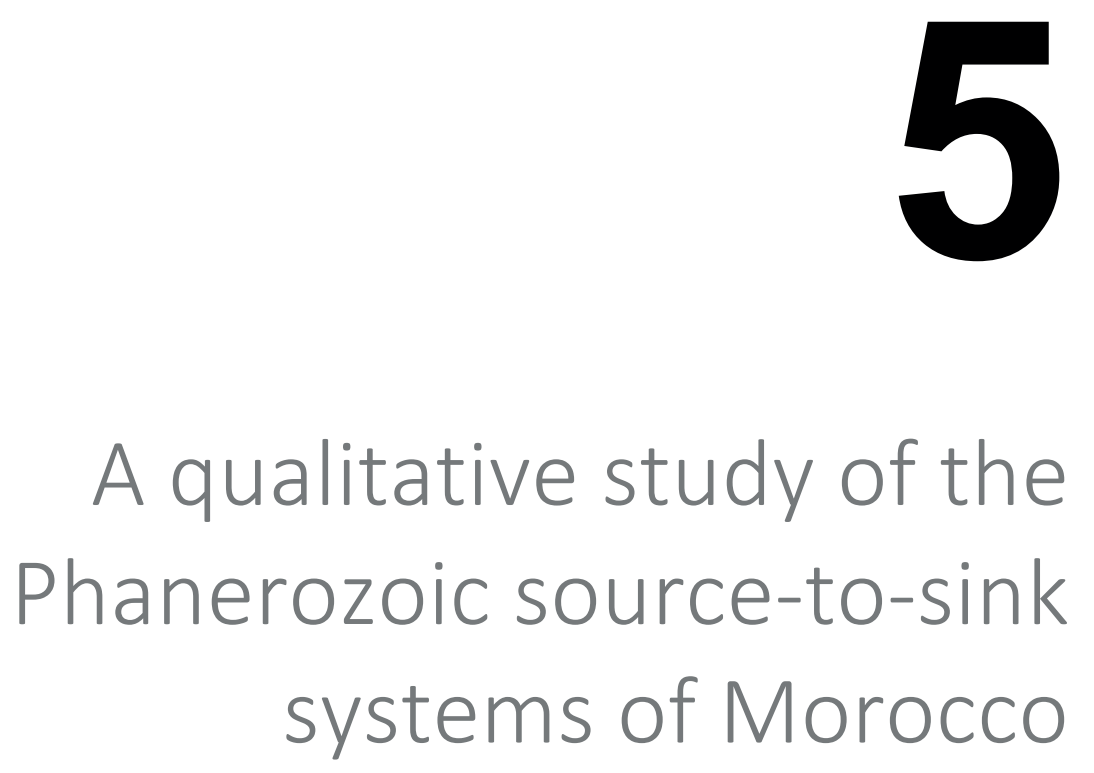

Abstract: We constructed 10 paleo- erosional and depositional maps, which we called "source-to-sink" maps. They cover the period between the Variscan and the presentday. The maps are based on the six following databases: 1) geological maps, 2) outcrop and fossil data, 3) well data, 4) paleo-geography and depositional environment maps, 5) provenance analysis, and 6) exhumation rates. The prevailing objective was to illustrate and discuss changes in the Permian to Neogene source-to-sink systems and the dynamicity of their components.

* Parts of this chapter will be submitted to Earth Science reviews: Charton et al., in preparation. Post-Variscan source-to-sink systems of Morocco and surroundings: A qualitative study. 


\subsection{Introduction}

Source-to-sink studies encompass the investigation of the exhumation history of the hinterland ('source'), the spatial distribution of fluvial and coastal deposits ('to'), and the architecture of continental traps, shallow and deep marine depocenters ('sink'; e.g. Allen, 2008; Sømme et al., 2009; Helland-Hansen et al., 2016). Analyses of this kind take into account geological surface processes, such as erosion, transportation, and deposition. Underlying mechanisms for the onset of source-to-sink systems are controlled by tectonic, eustatic, and/or climatic changes (e.g. Wells et al., 2017). The combination of state of the art sedimentary, stratigraphic, geochronology, provenance, palaeontology, Low-Temperature Thermochronology (LTT), and numerical analyses allows for building strong cases of integrated source-to-sink studies (e.g. HellandHansen et al., 2016). Sediment fluxes may be quantified by inverting the amount of deposited sediments in the sink, the erosion rate in the source, and other techniques that investigate the paleo drainage system (e.g. Wold and Hay, 1990; Gallagher et al., 1998; Barnes and Heins, 2008; Matenco et al., 2013). The sediment routing is an important parameter in dynamic systems, as it defines where the sediments will be delivered. From these notions, it seems evident that sediment budgets and pathways are crucial for hydrocarbon exploration.

Source-to-sink studies also have their limitations depending on, for instance, the spatial and temporal resolutions of each component, or simply on the quality of the sedimentary record. The creation of relief in the hinterland has sometimes been disregarded (see Helland-Hansen et al., 2016), despite the fact that the vertical motion rate, timing, extent, and the erodibility of the source areas are major parameters that significantly impact the sedimentary record in the basins.

Between the Variscan and Atlas orogenies, Morocco and surrounding areas have witnessed major geological events ${ }^{*}$. To illustrate these events, reconstructions of the Moroccan past, at various scales and within different fields of geosciences, have been carried out in several studies in the past decades (e.g. Ranke et al., 1982; Le Roy et al., 1997; Nemčok et al., 2005; Sibuet et al., 2012). These works presented depositional environments, structural, and/or geographic, paleo-maps based on extensive data collections.

Using the knowledge gathered hitherto in this Thesis, we construct 10 "source-to-sink maps", which account for the timing, extent, and strength of exhumation episodes documented with LTT and t-T modelling studies (chapters 2, 3, and 4). Using geological maps and several other databases (well, outcrop, fossil, and provenance data) and previous reconstructions as the basis for our maps, we also reconstructed the gross depositional environments. The maps presented in this chapter illustrate the source,

* Chapter 1 includes the geological history of Morocco. 
transitional, and sink domains from Permian to Neogene, while also including simplified structural framework. The aim of these maps is not to accurately define the paleodrainage systems, as the resolution of our datasets is too coarse, but to illustrate the dynamicity of the source-to-sink systems and of their components during the Phanerozoic in Morocco and surroundings, i.e. in post-orogenic, syn-rift, and post-rift settings. This chapter should hence be considered as a background study, creating an opportunity for future definition and quantification of sediments pathways and fluxes along the entire Moroccan rifted margin and into the interior of its adjacent continental crust.

\subsection{Data used to construct the source-to-sink maps}

We digitized the geological map of Morocco at 1:1,000,000 (Hollard et al., 1985). It resulted in widespread constraints for our maps, with the exception of the Permian, for which only very little sediments remain in the basins and even less are exposed. Several "updates" of the stratigraphy were brought to this map, especially around the Anti-Atlas (see chapters 2, 3, and 4) and in the Central High-Atlas. In the latter, the so-called "Couches Rouges" terrestrial redbeds comprised between Middle Jurassic and middle Cretaceous (Aptian) marine carbonates (Charrière and Haddoumi, 2016) have historically been attributed to the Middle and Late Jurassic (Hollard et al., 1985). Recent biostratigraphy work constrained the ages of the redbeds indeed to the Middle and Late Jurassic, but also to the Barremian (Early Cretaceous; reviewed in Charrière and Haddoumi, 2016). For neighbouring regions not covered by the Moroccan map, we digitized the map of NW Africa compiled by the UNESCO in 1990, for which no changes were made.

The outcrop and fossil data in Morocco is extensive, as suggested by the title of the recent special edition on Morocco from the journal "Geologues" (Number 194, septembre 2017): "Le Maroc, paradis des geologues". We have selected outcrop and fossil data from relevant publications to be used in this chapter (table 5.1).

The well database (fig. 5.1) is composed of DSDP and IODP well reports, confidential well reports and completion logs granted by the "Office National des Hydrocarbures Marocain" (ONHYM), detailed well data from published works (notably Michard et al., 2008), and limited well data such as total depth, reached formation, or stratigraphy only in other published studies or company reports. 


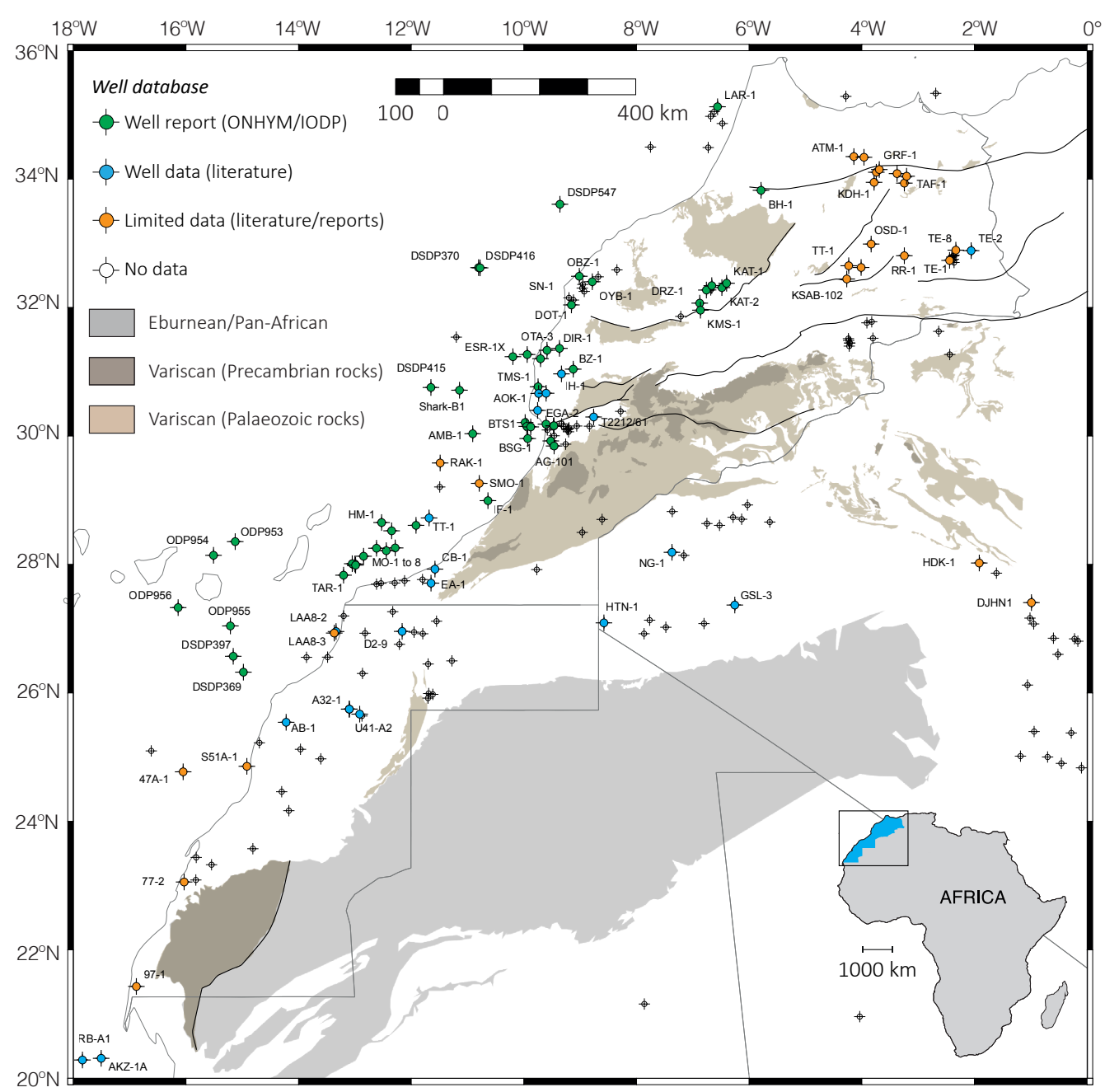

Figure 5.1. Location of boreholes in Morocco and surrounding NW African countries (nonexhaustive).

Furthermore, the present review was carried out within the North Africa Research Group (NARG), in which several other Ph.D. projects on the Moroccan geology are conducted. Some of these projects (Luber, 2017; Arantegui, 2018; Duval-Arnould, in prep.; Wang, in prep.) investigated the sedimentary records of the western High Atlas and north Tarfaya Basin. These works provide valuable high-resolution facies analysis, biostratigraphy, and regional reconstructions.

* The complete list of the references for the well database will be delivered upon request to the author. 
We used several types of paleo-reconstructions as the basis for depositional environments and general tectonic regime. The majority of the maps used in this chapter focused on depositional environments, paleogeography, tectonic plate reconstruction, and more local structural/stress maps (table 5.1). In some cases, we modified them according to new evidence (outcrop, fossil, and/or well data) published after these reconstructions. Sedimentary provenance analysis conducted in Morocco and surroundings for the Permian to Neogene periods are scarce; three investigated the provenance with detrital zircon U-Pb (Pratt et al., 2015; Marzoli et al., 2017; Domènech et al., in review), one study used traced elements and radiogenic Nd-Sr isotopes (Ali et al., 2014), and one produced detrital LTT ages (Sehrt, 2014). Nonetheless, more studies documented paleo-current directions in fluvial systems (e.g. Brown, 1980; Baudon et al., 2009).

As reviewed in the fourth chapter of this Thesis, numerous t-T modelling studies have been conducted in Morocco and surroundings. They yielded insights on the timing, location, and amplitude of exhumation and subsidence episodes affecting the presently exposed Precambrian/Variscan basement rocks. Geostatistics allowed us to interpolate vertical movement rates at the scale of the rifted margin of Morocco and to extend it over several 100s of kilometres into the interior of the African tectonic plate. We use the results of these interpolations to constrain the source domains, while modifying their extent based on the control points described above. 
Map Outcrop Data Fossil data

$\begin{array}{lc}\begin{array}{r}\text { Permian } \\ \text { (fig. 5.2) }\end{array} & \begin{array}{r}\text { Wartit et al., } 1990 \mid \text { Central Massif } \\ \text { Chalouan et al., 2008 | Rif basin }\end{array} \\ \text { Triassic } & \text { Brown, 1980 | Argana valley } \\ \text { (fig. 5.3) } & \text { Chalouan et al., 2008 | Rif basin }\end{array}$

Early Jurassic

(fig. 5.4)

Middle Jurassic

(fig. 5.5)

Late Jurassic

(fig. 5.6)

(early) Early

Cretaceous

(fig. 5.7)

middle Cretaceous

(fig. 5.8)

(mid-late) Late
Cretaceous

(fig. 5.9)

Palaeogene

(fig. 5.10)
Merino-Tome et al., 2017 | Eastern High Atlas

Sanders et al., 2015 | Rif basin

Steiner et al., 1998 | Canary Islands

Benvenuti et al., 2017 | Ouarzazate basin Charriere and Haddoumi, 2017 | Central High Atlas Merino-Tome et al., 2017 | Central High Atlas

Ouajhain et al., 2011 | Essaouira-Agadir basin

Benvenuti et al., 2017 | Ouarzazate basin Ouajhain et al., 2011 | Essaouira-Agadir basin Mekahli and Benhamou, 2004 | Eastern High Atlas

Steiner et al., 1998 | Canary Islands

Ali et al., 2014 | Tarfaya basin

Steiner et al., 1998 | Canary Islands

Aquit et al., 2013 | Tarfaya basin Benyoucef et al., 2015 | Guir Hamada Steiner et al., 1998 | Canary Islands

Aquit et al., 2013 | Tarfaya basin Chalouan et al., 2008 | Rif basin

Chalouan et al., 2008 | Rif basin Trappe, 1991 | Ouarzazate basin
Neogene

(fig. 5.11)
Broutin et al., 1989 | Argana valley

Doubinger, 1956 | Central Massif

Lagnaoui et al., 2016 | Argana valley

Kammerer et al., 2012 | Argana valley

Chalouan et al., 2008 | Rif basin

Lee, 1983 |Central High Atlas Jenny and Jossen, 1982 | Central High Atlas Bourillot et al., 2008 | Central High Atlas Beauvais, 1986 | Eastern High Atlas

Oukassou et al., 2016 | Middle Atlas Mahammed et al., 2005 | Eastern High Atlas Haddoumi et al., 2016 | Central High Atlas Monbaron and Taquet, 1981 | Central High Atlas

Ourribane et al., 2000 | Essaouira-Agadir basin Nouri et al., 2011 | Central High Atlas Touria Hssaida et al., 2014 | Rif basin

Benest et al., 1996 | Rif basin Middlemiss, 1980 | Essaouira-Agadir basin Ettachfini et al., 1998 | Doukkala basin Monbaron, 1978 | Middle Atlas

Ait Boughrous et al., 2007 | Guir Hamada Cavin et al., 2010 | Kem Kem beds Ibrahim et al., 2014 | Kem Kem beds Dhondt et al., 1999 | Tarfaya basin Benzaggagh et al., 2017 | Rif basin

Andreu and Tronchetti, 1994 | Middle Atlas Dhondt et al., 1999 | Tarfaya basin Ambroggi and Lapparent, 1954 | Essaouira-Agadir basin Mulder et al., 2000 | Essaouira-Agadir basin Rage and Wouters, 1979 | Settat basin

Zouhri et al., 2014 | Dakhla basin

Marivaux et al., 2017 | Dakhla basin Gingerich and Zouhri, 2015 | Tarfaya basin Adaci et al., 2007 | Kem Kem beds

Tabuce et al., 2005 | Ouarzazate basin Jouve et al., 2005 | Settat basin Gaffney et al., 2006 | Rif basin

Dartevelle, 1937 | Canary Islands Wijsman-Best and Boekschoten, 1982 | Porto Santo Keoniguer, 1967 | Dakhla Rage, 1976 | Middle Atlas Chevalier, 1962 | Safi basin Ennouchi, 1954 | Rif Saint Martin, 1990 | Rif Ennouchi, 1954 | Rif

Hugues-Alexandre et al., 2013 | Hauts Plateaux

Table 5.1. References used in this chapter to construct the source-to-sink maps. Fossil data was collected from Paleobiology Database (https://paleobiodb.org/\#/). 


\begin{tabular}{|c|c|c|}
\hline Map & Paleoreconstruction & Provenance strudy \\
\hline $\begin{array}{l}\text { Permian } \\
\text { (fig. 5.2) }\end{array}$ & $\begin{array}{l}\text { Broutin et al., } 1998 \text { | Meseta } \\
\text { Ellouz et al., } 2003 \text { | Atlas Systems } \\
\text { Chopin et al., 2014 | Atlas Systems }\end{array}$ & - \\
\hline $\begin{array}{l}\text { Triassic } \\
\text { (fig. 5.3) }\end{array}$ & $\begin{array}{c}\text { Leleu et al., } 2016 \text { | Morocco } \\
\text { Benvenuti et al., } 2017 \text { | Massif Ancien } \\
\text { Ait Brahim et al., } 2002 \text { | Atlas Systems } \\
\text { Ranke et al., } 1982 \text { | Tarfaya basin } \\
\text { Le Roy, 1997 | Atlantic Shelf }\end{array}$ & $\begin{array}{c}\text { Domenech et al., in review | Massif Ancien } \\
\text { Baudon et al., } 2009 \text { | Massif Ancien }\end{array}$ \\
\hline $\begin{array}{l}\text { Early Jurassic } \\
\text { (fig. } 5.4 \text { ) }\end{array}$ & $\begin{array}{c}\text { Ellouz et al., } 2003 \text { | Atlas Systems } \\
\text { Elmi et al., } 2009 \text { | Rif basin } \\
\text { Sibuet et al., } 2012 \text { | Atlantic } \\
\text { Laville and Pique, } 1991 \text { | Atlantic }\end{array}$ & Domenech et al., 2017 | Western High Atlas \\
\hline $\begin{array}{l}\text { Middle Jurassic } \\
\text { (fig. 5.5) }\end{array}$ & $\begin{array}{l}\text { Ellouz et al., } 2003 \text { | Atlas Systems } \\
\text { Nemcok et al., } 2005 \text { | Morocco }\end{array}$ & $\begin{array}{c}\text { Stets, } 1992 \text { | Massif Ancien } \\
\text { Pratt et al., } 2015 \text { | Middle Atlas }\end{array}$ \\
\hline $\begin{array}{l}\text { Late Jurassic } \\
\quad \text { (fig. 5.6) }\end{array}$ & $\begin{array}{l}\text { Ellouz et al., } 2003 \text { | Atlas Systems } \\
\text { Nemcok et al., } 2005 \text { | Morocco } \\
\text { Sibuet et al., } 2012 \text { | Atlantic } \\
\text { Ranke et al., 1982 | Tarfaya basin }\end{array}$ & Stets, 1992 | Rehamna \\
\hline (early) Early & Sibuet et al., 2012 | Atlantic & Ali et al., 2014 | Tarfaya basin \\
\hline $\begin{array}{l}\text { Cretaceous } \\
\text { (fig. 5.7) }\end{array}$ & $\begin{array}{c}\text { Aloui et al., } 2014 \text { | Algeria } \\
\text { Ye et al., } 2017 \text { | Reguibat Shield } \\
\text { Luber, 2018 | Essaouira-Agadir basin }\end{array}$ & $\begin{array}{c}\text { Lepretre, } 2015 \text { | Reguibat Shield } \\
\text { Pratt et al., } 2015 \text { | Rif basin } \\
\text { Luber, } 2018 \text { | Essaouira-Agadir basin }\end{array}$ \\
\hline $\begin{array}{l}\text { middle Cretaceous } \\
\text { (fig. 5.8) }\end{array}$ & Ye et al., 2017 | Reguibat Shield & $\begin{array}{c}\text { Essafraoui et al., } 2015 \text { | Massif Ancien } \\
\text { Meister et al., } 2017 \text { | Kem Kem beds } \\
\text { Pratt et al., } 2015 \text { | Rif basin } \\
\text { Ali et al., 2014 | Tarfaya basin }\end{array}$ \\
\hline $\begin{array}{l}\text { (mid-late) Late } \\
\text { Cretaceous } \\
\text { (fig. 5.9) }\end{array}$ & $\begin{array}{c}\text { Sibuet et al., } 2012 \text { | Atlantic } \\
\text { Ye et al., } 2017 \text { | Reguibat Shield } \\
\text { Ait Brahim et al., } 2002 \text { | Atlas Systems } \\
\text { van den Bogaard, } 2013 \text { | Canary Islands } \\
\text { Ranke et al., } 1982 \text { | Tarfaya basin }\end{array}$ & Ali et al., 2014 | Tarfaya basin \\
\hline $\begin{array}{r}\text { Palaeogene } \\
\text { (fig. 5.10) }\end{array}$ & $\begin{array}{c}\text { Ranke et al., } 1982 \text { | Tarfaya basin } \\
\text { Ait Brahim et al., } 2002 \text { | Atlas Systems } \\
\text { van den Bogaard, } 2013 \text { | Canary Islands }\end{array}$ & - \\
\hline $\begin{array}{l}\text { Neogene } \\
\text { (fig. 5.11) }\end{array}$ & Ranke et al., 1982 | Tarfaya basin & Ali et al., 2014 | Tarfaya basin \\
\hline
\end{tabular}




\subsection{Source-to-sink maps}

The presented maps are defined according to the geological time chart division (with a strong focus on the Cretaceous and Jurassic periods). The time-windows covered by the maps are as follow: Permian (300 to $252 \mathrm{Ma}$; fig. 5.2), Triassic (252 to $201 \mathrm{Ma}$; fig. 5.3), Early Jurassic (201 to $174 \mathrm{Ma}$; fig. 5.4), Middle Jurassic (174 to $163 \mathrm{Ma}$; fig. 5.5), Late Jurassic (163 to $145 \mathrm{Ma}$; fig. 5.6), (early) Early Cretaceous (145 to $125 \mathrm{Ma}$; fig. 5.7), middle Cretaceous (125 to $90 \mathrm{Ma}$; fig. 5.8), (mid-late) Late Cretaceous (90 to $66 \mathrm{Ma}$; fig. 5.9), Palaeogene (66 to $23 \mathrm{Ma}$; fig. 5.10), and Neogene (23 to $0 \mathrm{Ma}$; fig. 5.11).

Four types of depositional environments are described in this work: terrestrial, transitional, shallow marine, and marine. For most of the control points, the environments were already interpreteded in the associated study (table 5.1). In other instances, we interpreted the depositional environment based on lithology and/or fossil data. In the following maps, the transitional environments usually suggest a coastal situation, but may account for areas characterised by the fluctuation between shallow marine and terrestrial environments.

The exhumation pattern recognised here is already described in the fourth chapter, and the depositional environment and structural reconstructions are well described in the literature (table 5.1). Therefore, in the following text, we focus on the changes that occurred from one period to another, as well as on the source-to-sink systems. We used the results of sedimentary provenance and paleo-current studies as a proxy for the source-to-sink systems, illustrated with black arrows in our maps.

From the Permian to the Triassic (figs. 5.2 and 5.3), the source area shifted from most of the domain affected by the Variscan orogeny to part of it: the Meseta, the Anti-Atlas, and the eastern Reguibat Shield. The presence of transitional depositional environments is another important change, resulting from marine incursions from the Tethysian realm as far as the Tarfaya basin (e.g. Ranke et al., 1982; Scotese, 2012; Leleu et al., 2016). The erosion that occurred in the Anti-Atlas during the Triassic is supported by provenance and paleo-current evidences in the Massif Ancien (Brown, 1980; Baudon et al., 2009; Domènech et al., in review) evidencing a drainage divide perpendicular to the Anti-Atlas trends.

From the Triassic to Jurassic (figs. 5.3 and 5.4) the marine domain steadily covered the Atlas and Central Atlantic rifted domains. There are no significant changes in source areas, excepted for the western Reguibat Shield, where the exhumation starts in the Early Jurassic. The recent provenance study of Marzoli et al. (2017) shows that sediments above the CAMP basalts in the western High Atlas have been sourced from the Meseta domain.

The Early and Middle Jurassic epochs (figs. 5.4 and 5.5) are fairly similar in terms of depositional environments and the exhumation patterns are identical as they originate from the same "exhumation" map. The Late Jurassic epoch (fig. 5.6) however shows a 
major shift in the sediment source areas: the Anti-Atlas is no longer an active source while the Meseta is strongly exhumed. It is worth noting that a high-resolution clay mineralogy study was carried out in folded Jurassic sediments of the Essaouira-Agadir Basin (Ouajhain et al., 2011). The study shows a clear shift of sediment source lithology or area between the Middle and Late Jurassic, passing from a chlorite-dominated assemblage to a illite-dominated assemblage. It is possible that the Early to Middle Jurassic erosion of the Anti-Atlas reached the Precambrian, hence cutting through the metamorphosed Palaeozoic series, and eventually sourcing chlorites to surrounding basins.

Depositional environments in the Essaouira-Agadir basin change from fluvial to lagoonal during the Early Jurassic, from continental/transitional to shallow marine in the Middle Jurassic, and remained on the shelf during the Late Jurassic (Duval-Arnould, in prep.). In the Sidi Ifni area, Arantegui (2018) documented a Bathonian (Middle Jurassic) age for the shallow marine and lacustrine deposits (more details in chapter 3).

During the Middle Jurassic (fig. 5.5), provenance studies carried out on Jurassic sediments evidenced a transport of sediment from the Meseta to the Middle Atlas (Pratt et al., 2015), and from the Anti-Atlas to the Essaouira-Agadir basin (Stets, 1992). The Meseta is also a documented source area during the Late Jurassic, as suggested by paleo-currents measured in the western High Atlas (Stets, 1992). 


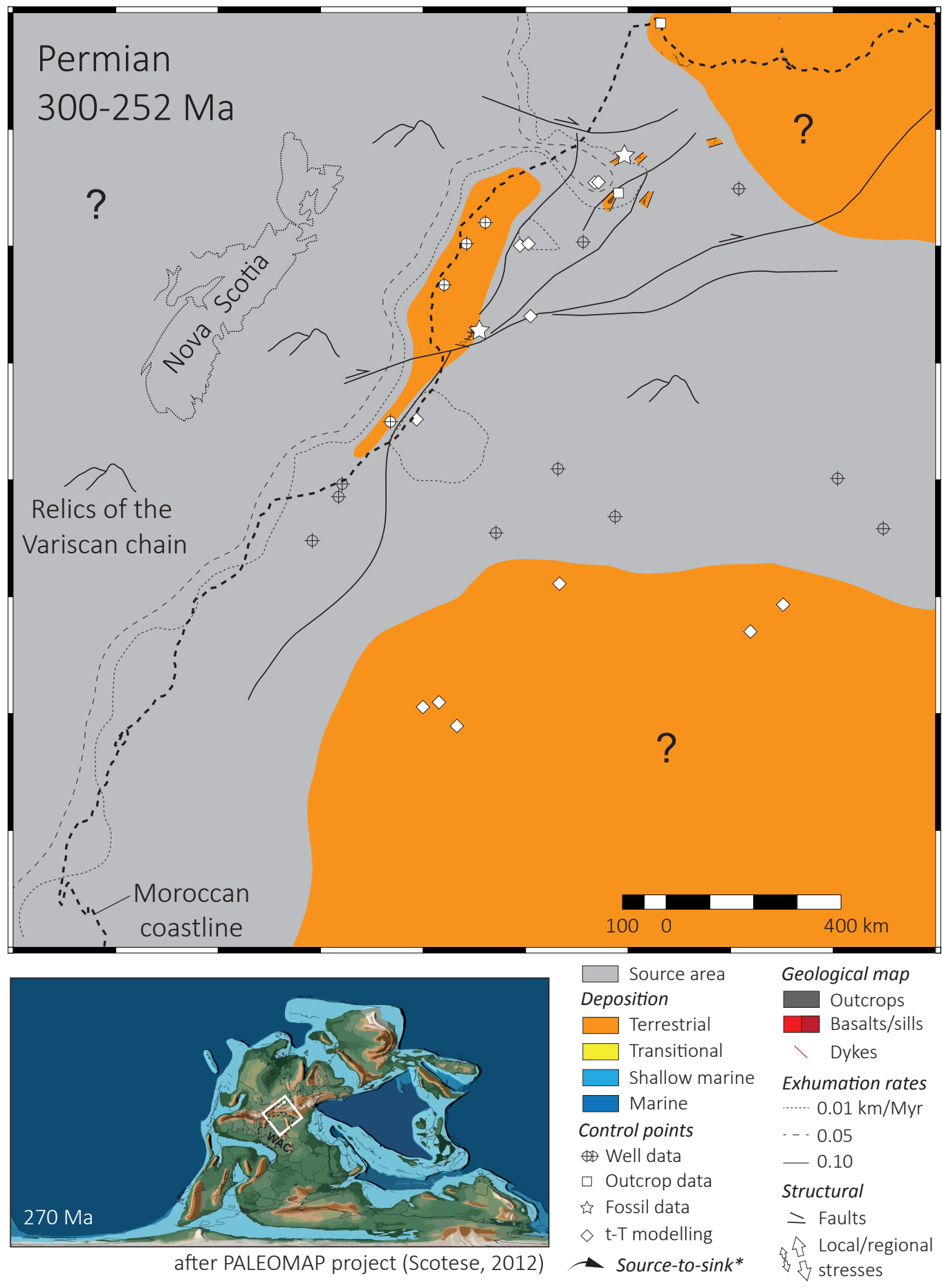

Figure 5.2. Permian map. * Simplified source-to-sink systems evidenced with provenance study or paleo-currents. WAC: Western African Craton 


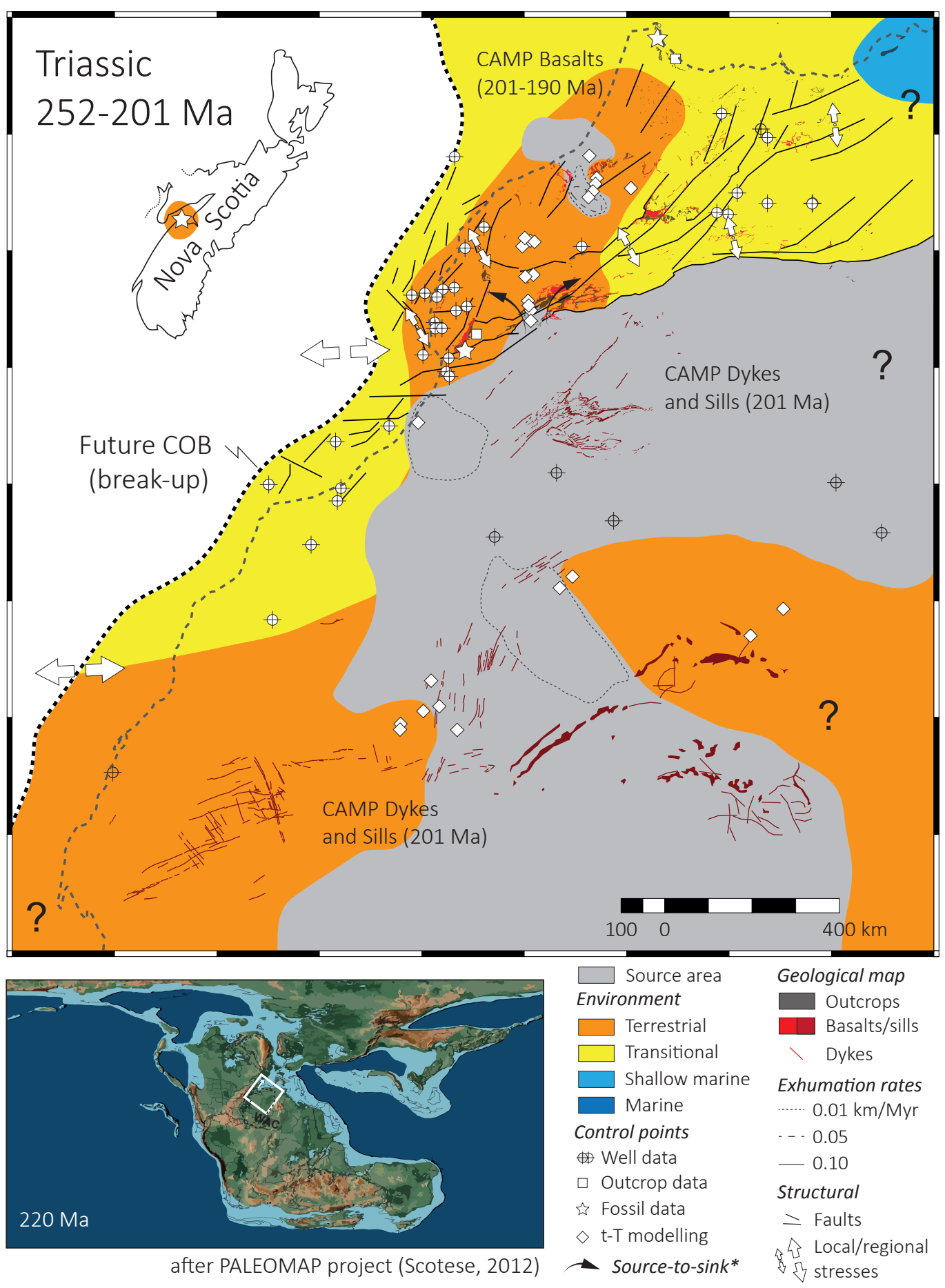

Figure 5.3. Triassic map. * Simplified source-to-sink systems evidenced with provenance study or paleo-currents. CAMP: Central Atlantic Magmatic province. 


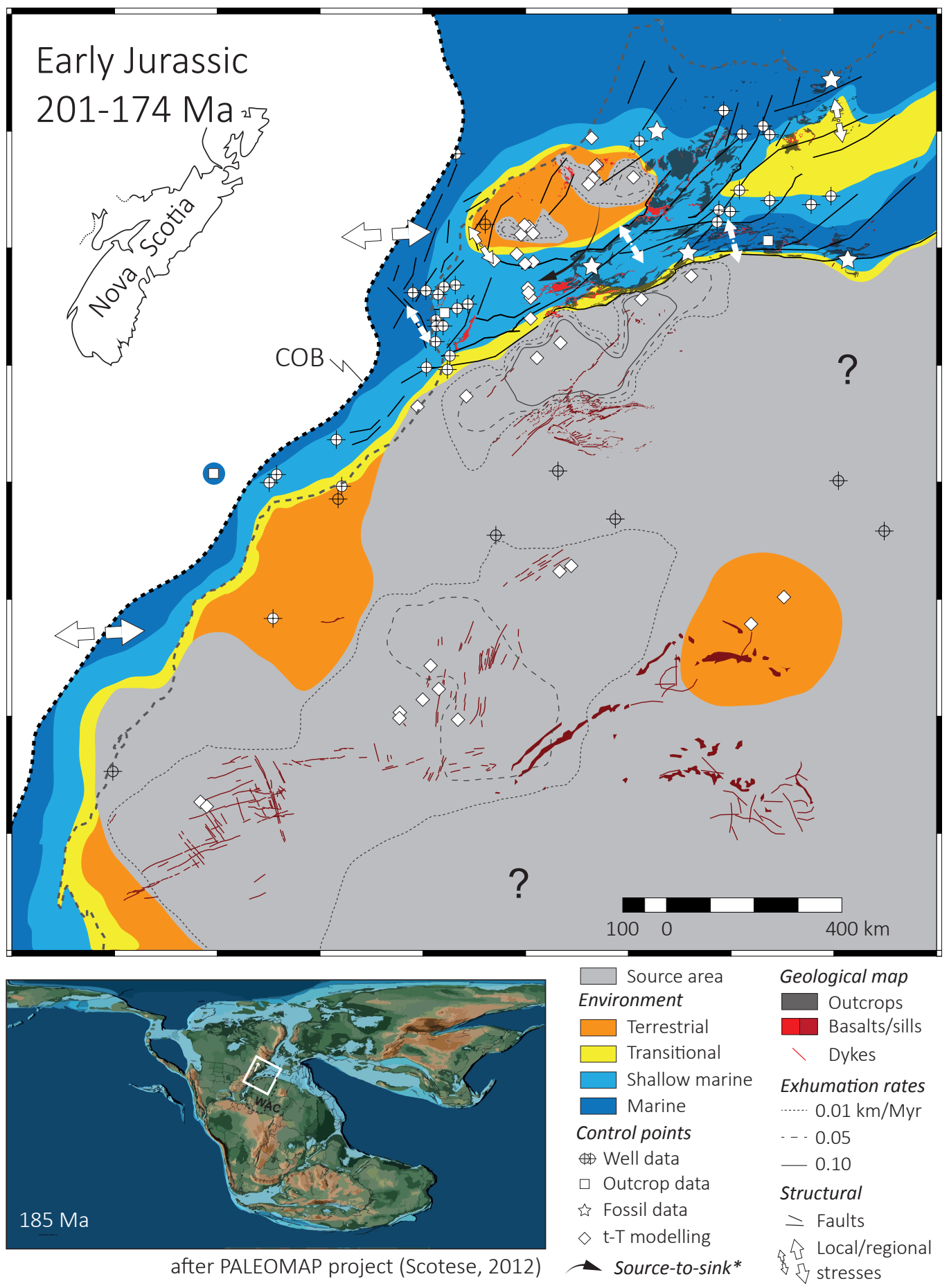

Figure 5.4. Early Jurassic map. * Simplified source-to-sink systems evidenced with provenance study or paleo-currents. CAMP: Central Atlantic Magmatic province. 


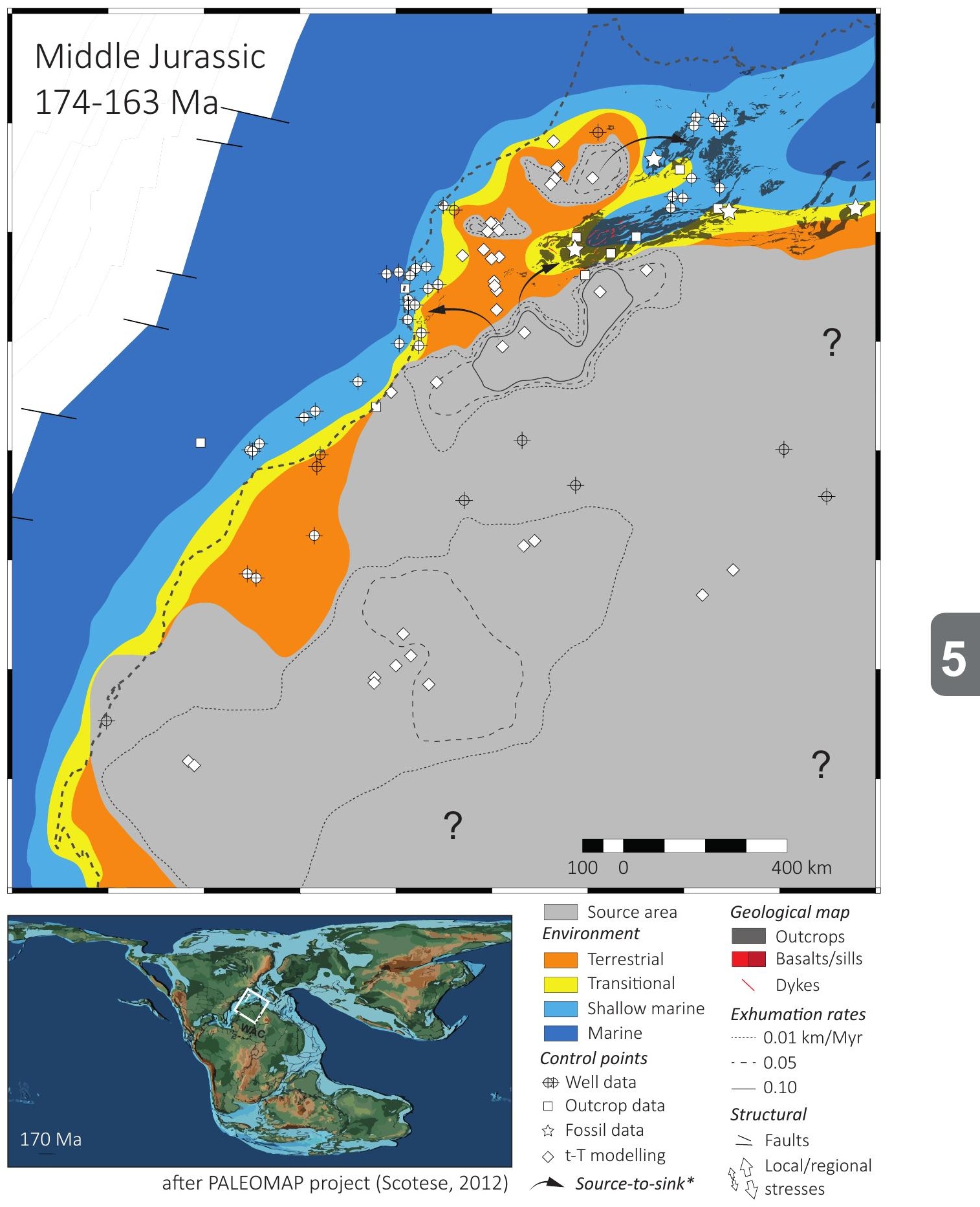

Figure 5.5. Middle Jurassic map. * Simplified source-to-sink systems evidenced with provenance study or paleo-currents. 


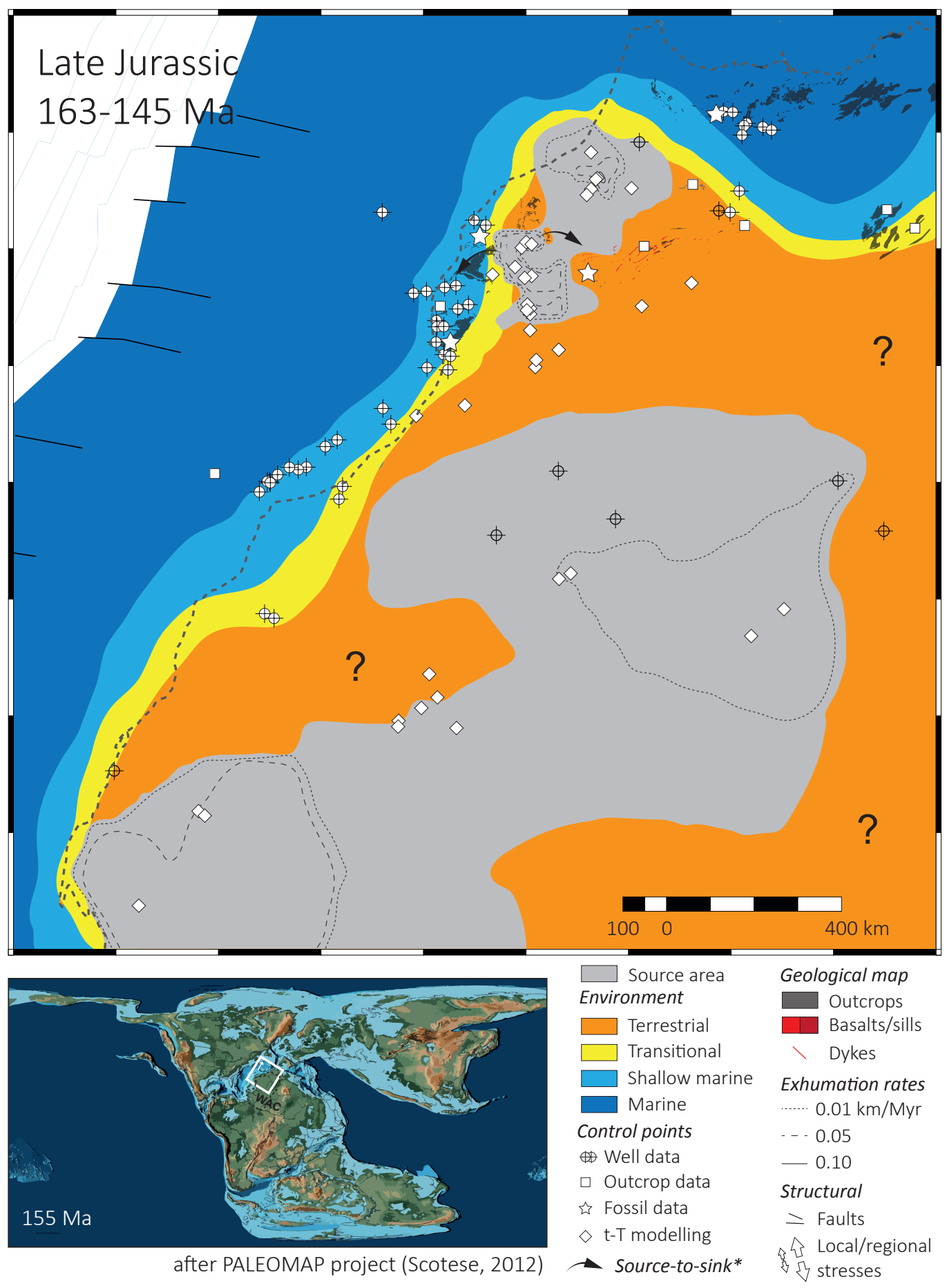

Figure 5.6. Late Jurassic map. * Simplified source-to-sink systems evidenced with provenance study or paleo-currents. 


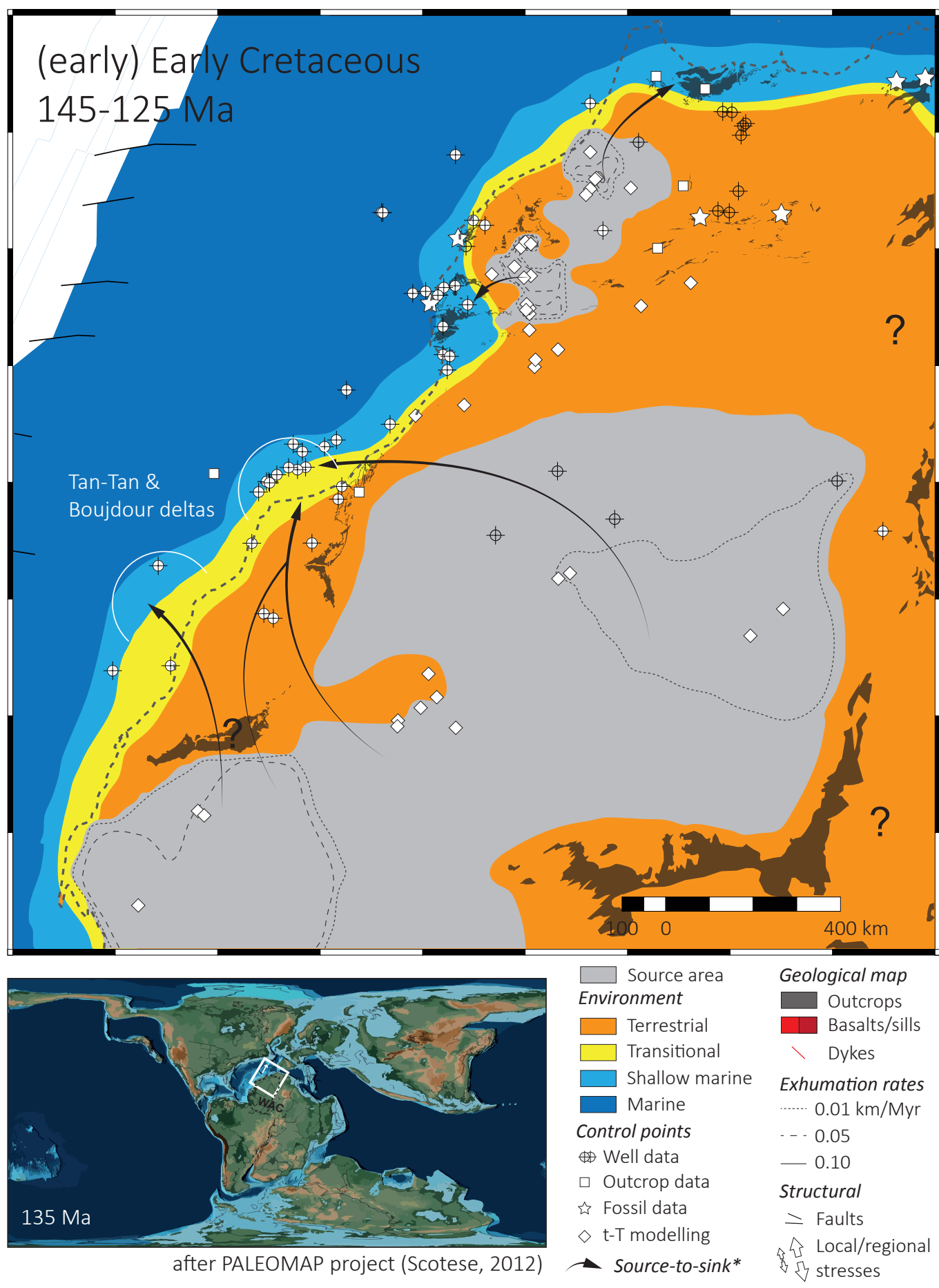

Figure 5.7. (Early) Early Cretaceous map. * Simplified source-to-sink systems evidenced with provenance study or paleo-currents. 


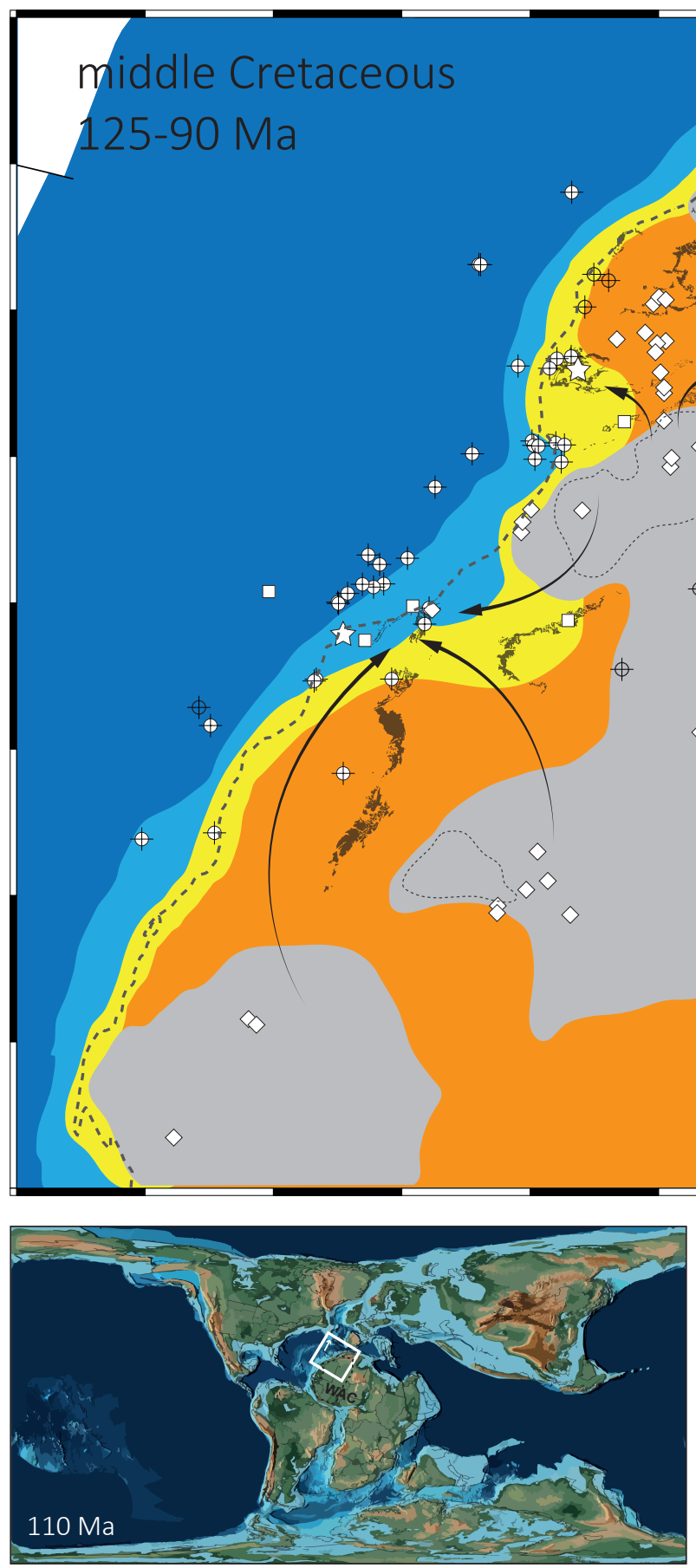

after PALEOMAP project (Scotese, 2012)

$\phi$
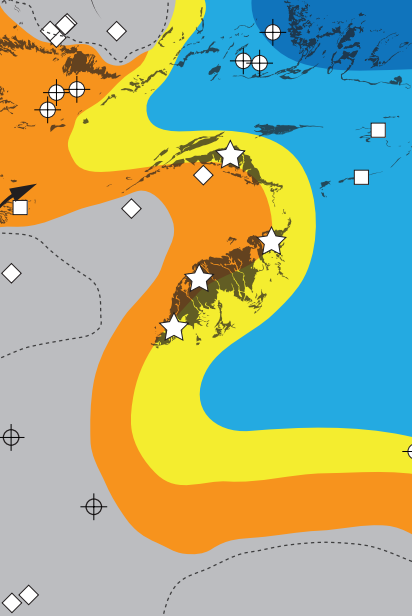

$\phi$

$\diamond$

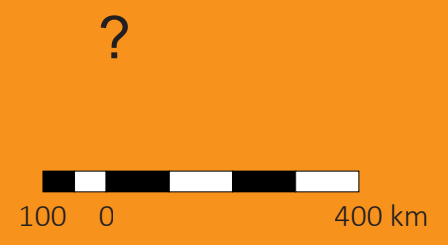

Source area

Environment

Geological map

Terrestrial

Outcrops

Transitional

Shallow marine

Marine

Control points

Well data

$\square$ Outcrop data

is Fossil data

$\diamond \mathrm{t}$-T modelling

$\rightarrow$ Source-to-sink*

Basalts/sills

$\backslash$ Dykes

Exhumation rates

$0.01 \mathrm{~km} / \mathrm{Myr}$

- - 0.05

$-0.10$

\section{Structural}

$\geq$ Faults

4) Local/regional

$\sqrt{3}$ stresses

Figure 5.8. Middle Cretaceous map. * Simplified source-to-sink systems evidenced with provenance study or paleo-currents. 


\section{(mid-late) Late Cretaceous 90-66 Ma}

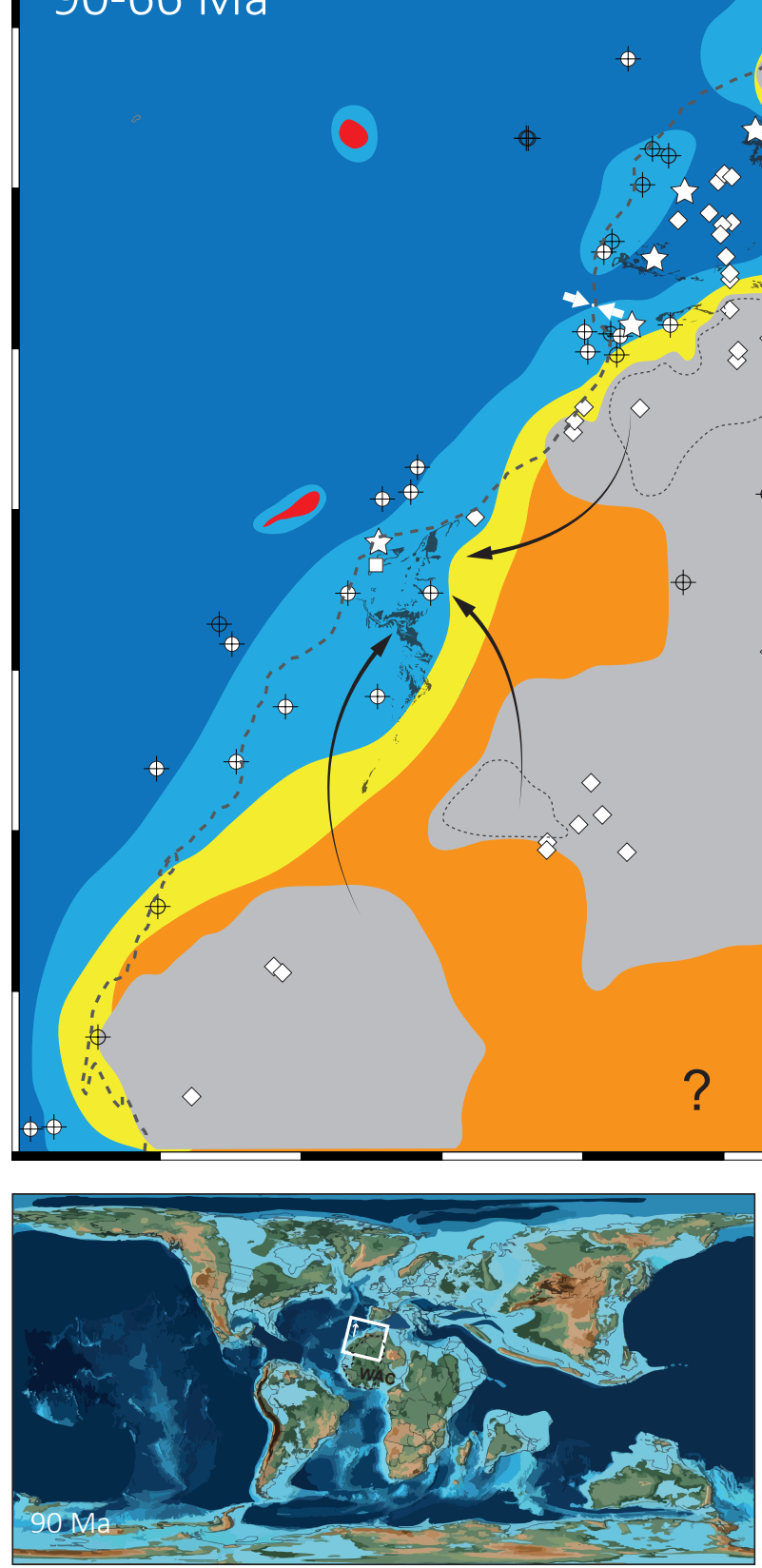

after PALEOMAP project (Scotese, 2012) $\square$ Source area Environment

Terrestrial Transitional Shallow marine Marine

Control points

Well data

$\square$ Outcrop data

¿ Fossil data

$\diamond \mathrm{t}-\mathrm{T}$ modelling

- Source-to-sink*

Figure 5.9. (mid-late) Late Cretaceous map. * Simplified source-to-sink systems evidenced with provenance study or paleo-currents. 


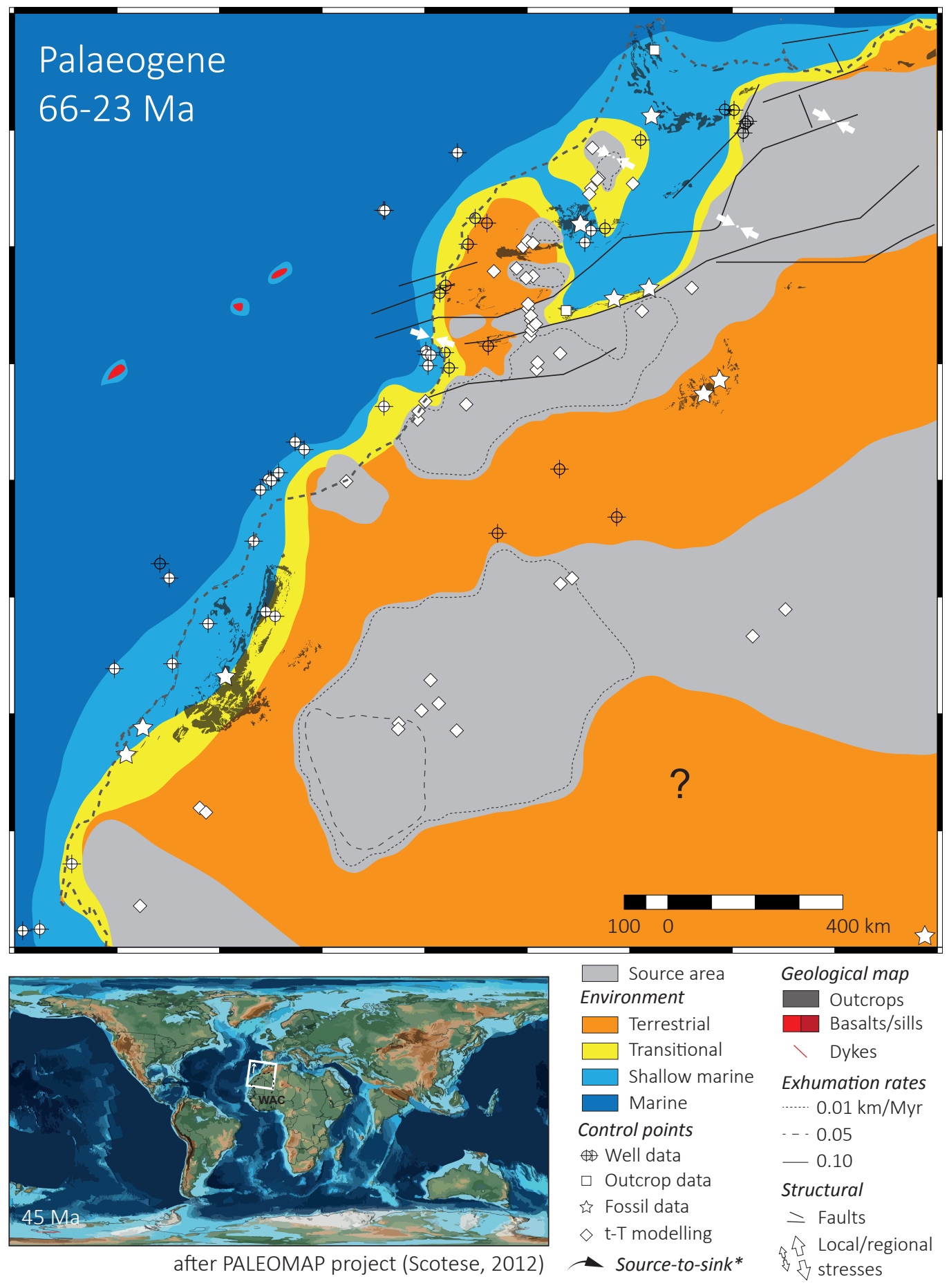

Figure 5.10. Palaeogene map. * Simplified source-to-sink systems evidenced with provenance study or paleo-currents. 


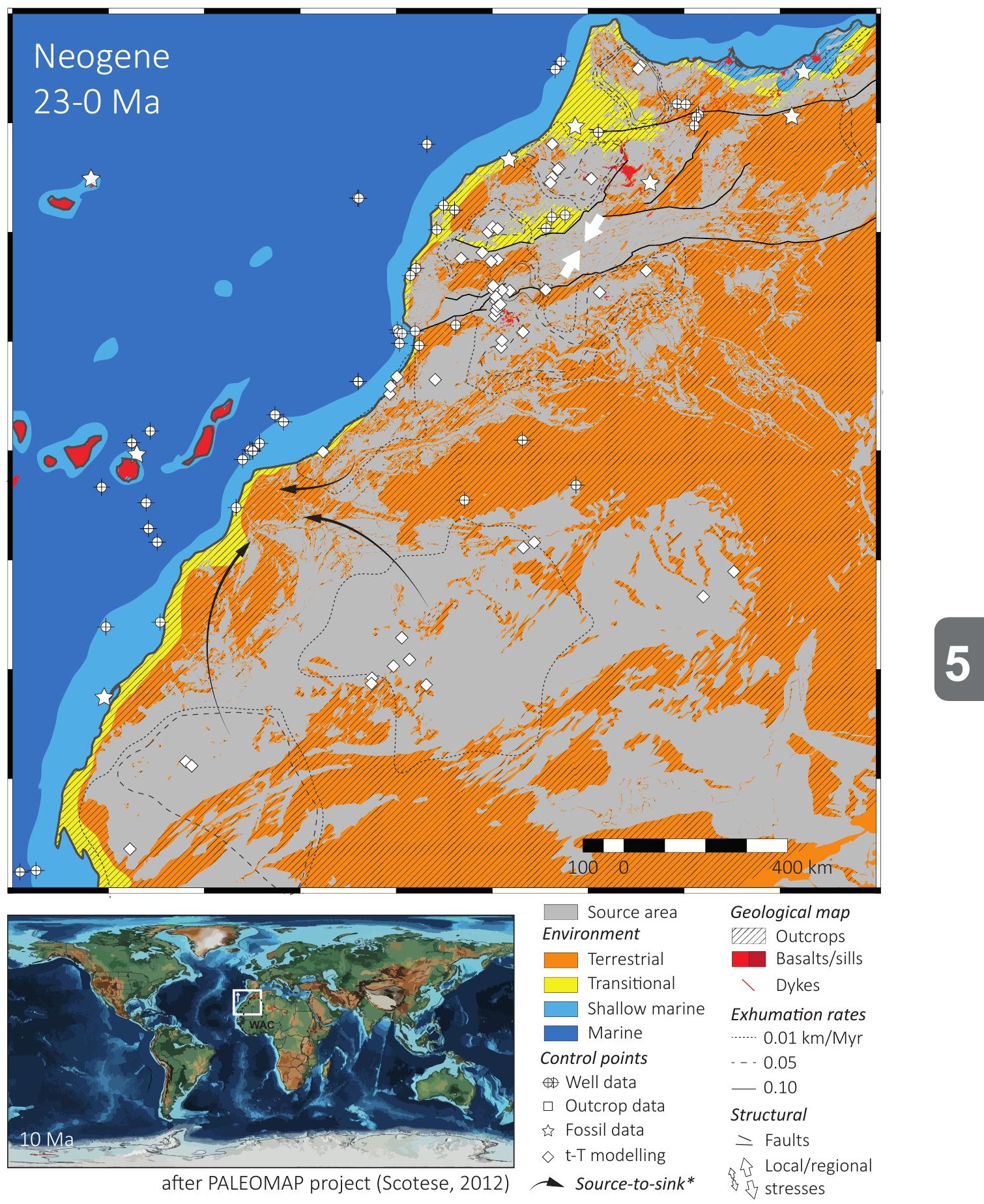

Figure 5.11. Neogene map. * Simplified source-to-sink systems evidenced with provenance study or paleo-currents. 
The transition between the Jurassic and Cretaceous (fig. 5.6 and 5.7) is fairly monotonous. The coastline shifted towards the north in the Middle Atlas/Rif areas, and towards the west in the Tarfaya basin. The latter change was accompanied by the onset of large Early Cretaceous deltaic systems (Tan-Tan and Boujdour deltas). The entire Reguibat Shield was an active source of sediments since the Early Jurassic. This suggests that an acceleration of the exhumation or a change in eroded lithologies in the Reguibat Shield must have occurred in the earliest Cretaceous, supplying the siliciclastics to the Tan-Tan and Boujdour deltas. It is likely that the erosion in the Reguibat Shield reached the granitic basement at the end of the Jurassic, with a prior removal of the Variscan meta-pelites from the Early Palaeozoic basin.

In the Late Jurassic and Early Cretaceous, it is unknown if the Tindouf basin was also sourcing sediments to the Tarfaya deltas, as no AFT ages were produced. Nevertheless, values of vitrinite reflectance from the Silurian (Kuuskraa and Moodhe, 2013) suggest that there is a missing layer that was deposited and subsequently eroded between the Carboniferous and the Late Cretaceous (values are too high for the preserved overburden). As most of the Anti-Atlas and the central Reguibat Shield were subsiding during the Late Jurassic/Early Cretaceous epochs, we assume that the Tindouf basin missing layer was deposited then.

The Cretaceous (figs. 5.7, 5.8, and 5.9) is characterised by another post-Variscan shift in sediments source areas. In Morocco, widespread coarse sediments are described in the Early Cretaceous (e.g. Davison, 2005; Frizon de Lamotte et al., 2009). During the Middle Cretaceous, the central Anti-Atlas became an active source area and the Meseta exhumation slowed down significantly (chapter 4). At the end of the Cretaceous, the entire Anti-Atlas s.s. was sourcing sediments to surrounding basins, and most of the Meseta and High Atlas domains were subsiding.

In the north Tarfaya basin, Arantegui (2018) shows that the undifferentiated early Early Cretaceous clastic succession is characterised by fluvial and tidal flat environments, with conglomerates at the base in contact with Cambrian metamorphosed sediments. The study further provides an updated biostratigraphy of the Aptian-Albian (Middle Cretaceous) transitional to shallow marine deposits. The mean paleo-current direction for the fluvial unit indicate a transport direction towards the northwest.

The transition from shallow marine to continental deposition environment between the Early and the Middle Cretaceous in the Essaouira-Agadir basin is characterised by a general paleo-current direction towards the west (Luber, 2018). In the Late Aptian and Albian times, the area was drowned once again with the establishment of shallow marine conditions.

Cenomanian-Turonian (Middle Cretaceous) carbonate platform with low detrital influx was prevailing in the Central High Atlas, while in the Atlantic domain the Turonian organic-matter rich black shales were deposited in a relatively deeper marine environment (Wang, in prep.). 
Provenance studies suggest that only the Reguibat Shield and Mauritanides were sourcing clastic sediments to the north Tarfaya basin during the Early Cretaceous, while the Anti-Atlas was part of the in the siliciclastic supply to the coastal basin from Late Cretaceous onwards (Ali et al., 2014). Pratt et al. (2015) collected Albian sediments deposited in the Rif basin, and traced the provenance to two sources: a Mesetian one and a presently unknown (i.e. eroded) source area.

During the Palaeogene (fig. 5.10) most of the study area was emerged. Epicontinental basins developed around the exhuming massifs of the Meseta and the High Atlas, and shallow marine setting persisted in the Tarfaya basin. The dinosaurs are gone: Paleontological evidences are rests of fishes, lizards, and mammals (whales, turtles...).

The Neogene period (fig. 5.11) shows only minor differences with the present-day situation, as nearly all of Morocco is emerged. Important sediment source areas are the Meseta, the High Atlas, the Anti-Atlas, and the Reguibat Shield. Some shallow marine sinks were developed in the North Tarfaya southern Settat, and Gharb basins, and along the Mediterranean coast in the Rif domain.

\subsection{Limitations}

Data quality, data density, and temporal resolution are very variable across the "sourceto-sink" maps. This leads to variable robustness of the presented maps, which complicates the comparisons from one to another. Dating is the primary uncertainty, as several Phanerozoic layers are undifferentiated in Morocco and surroundings (e.g. Hollard et al., 1985). This is for instance the case of Permo-Triassic, Middle to Late Jurassic, and Early to Middle Cretaceous redbeds ("Continentale Intercalaire"), all three more or less widely mapped in the study area, but their ages are weakly constrained. These layers may be intercalated by dated marine sequences or magmatic intrusions, but the biostratigraphic or geochronologic studies are generally local and extrapolation still has to be made for similar but non-constrained facies.

The Permian map remains the most speculative as it was constrained with very limited amount of data. While the Neogene is a data rich time interval and the corresponding maps is better constrained. Another limiting aspect is introduced by the definition of the time-windows that each map covers. Indeed, the temporal resolution of the Permian and Triassic maps is coarse, as they encompass ca. $50 \mathrm{Myr}$, especially when compared to the short Middle Jurassic interval (ca. $11 \mathrm{Myr}$ ). It is also important to note that the Triassic map is mostly composed of Late Triassic data, as Early and Middle Triassic times are rarely documented in the stratigraphy of Morocco. Indeed, the faults and stresses are rift related, and therefore most likely Late Triassic. The Triassic sediments are mapped as undifferentiated Triassic or as Late Triassic and the CAMP dykes and sills occurred in the lattermost Triassic. However, the exhumation rates were calculated for the entire Triassic, which might introduce a bias in the map. 
Moreover, our "source-to-sink" maps are using the present-day geography and geology as base maps. In other words, this means that the maps are unrestored. This should definitely be taken into account when reading them and discussing implications for the Atlas and Rif belts, for which Cenozoic upheaval was mostly caused by N-S compression (e.g. Michard et al., 2008). Our overall message is that the Permian and Triassic maps are the least constrained among the constructed paleo-maps.

\subsection{Conclusions}

In this chapter, we constructed 10 paleo- structural, erosional, and depositional maps from Permian to the present-day, which we called "source-to-sink" maps.

During the Permian, terrestrial basins were located in the Meseta and were sourced with eroded material of the Variscan chain. In Morocco, our data collection from the Permian is scarce, and yet scarcer in Moroccan surroundings.

In the Triassic, the deposition occurred in manier places. Active sedimentary source areas were the Central Massif (northern Meseta), the (western) Anti-Atlas, and the (central) Reguibat Shield. Terrestrial/transitional environments covered the High Atlas, the Meseta, and the Tarfaya basins as well as part of the Reguibat Shield.

Throughout the Jurassic, shallow marine and marine environments are well recognised. Active sedimentary source areas were the Anti-Atlas, the Reguibat Shield, and the Meseta massifs. A substantial shift of source area was evidenced from the Anti-Atlas to the Meseta/High Atlas at the transition between the Middle and the Late Jurassic (ca. $163 \mathrm{Ma})$.

In the Cretaceous, terrestrial environments are covering a substantial portion of the study area, especially between 145 and $125 \mathrm{Ma}$. Another considerable shift of source area was evidenced from the Meseta/High Atlas to the Anti-Atlas at the transition between the early Early and the middle Cretaceous (ca. $125 \mathrm{Ma}$ ).

Last, during the Cenozoic, almost all presently outrcopping basement areas were sourcing material to the coastal and foreland basins. 
Acknowledgements: NARG members Angel Arantegui, Tim Luber, Aude Duval-Arnould, Leonardo Muniz-Pichel, Jianpeng Wang, and Emmanuel Roquette are thanked for their valuable collaboration. Aude Duval-Arnould and Emmanuel Roquette are thanked for proofreading this chapter. Emilie Chaillan is thanked for digitizing the Cretaceous outcrops from the NW African geological maps. 



\title{
6
}

\section{Discussion: Vertical movements and underlying mechanisms}

\begin{abstract}
The potential mechanisms responsible for the onset and continuation of the $\mathrm{km}$-scale unpredicted vertical movements are discussed in this chapter. The different compilations and comparisons of data hitherto gathered show that low-temperature thermochronology ages related to rifting, if ever present, have been overprinted by post-rift events. The mechanisms previously proposed for the Moroccan case account for local to regional observations. However, not all of these poposed mechanisms account for the large-scale and more general observations. On the other hand, recent studies have submitted that mantle-driven dynamic topography should be considered as a general underlying cause for both upward and downward movements observed in many places of the world. However, this process does not take into account the local and regional observations. We argue that a combination of large-scale crustal folding, mantle-driven dynamic topography, and thermal subsidence, was instrumental to the exhumation and subsidence episodes. Moreover, these large-scale episodes were superimposed by changes in climates, sea level, and erodibility of the exposed rocks, overall contributing to the vertical movement timings, patterns, and amplitudes observed in Morocco and its surroundings.
\end{abstract}




\subsection{Introduction}

One of the characteristics of the $\mathrm{km}$-scale unpredicted exhumation and subsidence episodes occurring in Morocco that remains unconstrained is the triggering process(es). In this chapter, we discuss the possible mechanisms responsible for the onset and persistence of these movements.

First, we elaborate on the rifting and drifting tectonics. We secondly examine the dataset of Low-Temperature Thermochronology (LTT) ages in Morocco and surroundings to possibly define trends that are expected along passive margins. Third, we review the processes that were proposed for Morocco as likely candidates to explain the observed exhumation and subsidence episodes. Fourth, we elaborate on the tectonic implications of the results obtained hitherto in this Thesis and compare them to published data, which includes the comparison of the present-day architecture and evolution of the Sidi Ifni transect to other segments across the Moroccan rifted margin, the wavelengths of vertical movements from the Anti-Atlas to the rest of Morocco, and the exhumation and subsidence rates to instances in the literature where the mechanisms are known. Last, we compile and compare different proxies for tectonic, climate, and eustatic changes.

\subsection{Expected tectonic evolution along a rifted passive margin}

Several types of rifts and passive margins exists (e.g. Allen and Allen, 2013). These types may be categorised in several fashions, based on their geodynamic context, volcanic activity, width, or other aspects. We will focus on the tectonics expectedly involved in the case of the Central Atlantic rifting and drifting (fig. 6.1).

The rifting of the Central Atlantic is considered as passive (e.g. Tankard and Welsink, 1989) and asymmetric (e.g. Piqué and Laville, 1996; Gouiza, 2011). The early Mesozoic rifting was characterised by a wide rifted zone (Frizon de Lamotte et al., 2015), important terrigenous inputs, salt sedimentation, and by the Central Atlantic Magmatic Province (CAMP; e.g. Michard et al., 2008). 


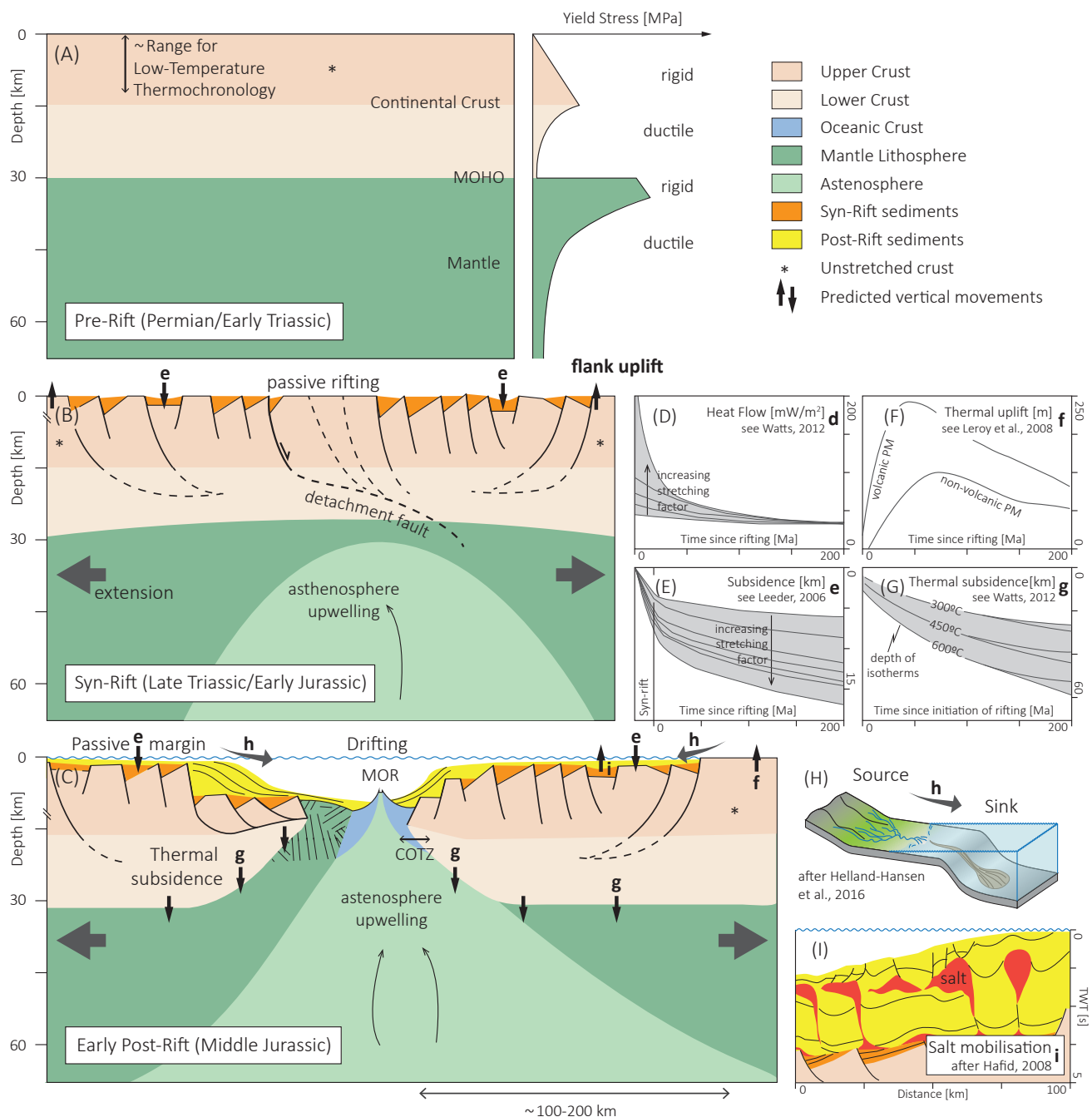

Figure 6.1. Summary of the vertical movements expected in the Central Atlantic margins and their adjacent continental crusts (after Gouiza et al., 2010). A), B), and C) Pre-, Syn-and post-rift situations, respectively. MOR: Mid-Oceanic Ridge (spreading centre); COTZ: Continent-Ocean Transition Zone. D), E), F), and G) Evolution of different aspects of a rifted continental margin. H) and I) Cartoons illustrating source-to-sink systems and salt mobilisation, respectively. 
Passive rifting develops in an extensional geodynamic context, with extension driven by plate movements (e.g. Michon and Merle, 2003). It has been suggested that passive rifting is characterised by lithospheric stretching, asthenosphere upwelling, high surface heat-flow (fig. 6.1D), seismic activity, negative Bouguer anomalies, normal faults reaching deep within the continental crust, and thermal anomalies at depth (e.g. Huismans and Beaumont, 2011; Allen and Allen, 2013). Asymmetric rifts, which may lead to mantle exhumation along a detachment fault, are characterised by simple shear and high extension rates (Michon and Merle, 2003). It was also evidenced that asymmetric rifts can result from rift zone migration (for details, see Brune et al., 2014). The adjacent unstretched continental lithosphere (rift flanks) may be affected by small scale convection, volcanism, and uplift (fig. 6.1B; e.g. Olsen, 1995; Allen and Allen, 2013). Predicted syn-rift vertical movements are substantial and rapid subsidence in the rift zone (fig. 6.1E; McKenzie, 1978) and uplift or no motions in the rift flanks (Olsen, 1995; Huismans and Beaumont, 2011).

The passive margin of northwest Africa is a rifted, mature, fairly narrow, sedimentnourished margin (e.g. Michard et al., 2008). It is considered as non-volcanic, or magmapoor, as the continental margin lacks seaward dipping reflectors (e.g. Contrucci et al., 2004; Biari et al., 2017).

Rifted magma-poor continental margins are characterised by seaward dipping normal faults and a break-up unconformity (e.g. Paton et al., 2017). The predicted post-rift vertical movement in rifted margins is a slow and continuous subsidence (fig. 6.1E; McKenzie, 1978), linked to thermal cooling of the lithosphere (fig. 6.1.G; e.g. Bertotti, 2001; Watts, 2012). The adjacent unstretched continental lithosphere is assumed as tectonically quiescent in most models of passive margins evolution (reviewed in Watts, 2012). However, some studies have shown that post-rift uplift and exhumation can be predicted in the unstretched lithosphere adjacent to rifted margins (fig. 6.1F; Leroy et al., 2008; Yamato et al., 2013). The modelled vertical movements were explained as resulting from asthenosphere upwelling or thermal induced flexural response of the lithosphere.

Source-to-sink systems may result from the erosion of the unstretched lithosphere if its surface resides above sea level (e.g. Martinsen et al., 2010; Helland-Hansen 2016; fig. $6.1 \mathrm{H}$ ). The so-called 'passive-margin sands' are a product example of such systems (e.g. Garzanti et al., 2014). Finally, the sedimentary overburden in a sediment-rich margin, alongside other processes, is susceptible to trigger salt mobilisation and local uplifts (fig. 6.1G; e.g. Pichel et al., 2017). 
6.3. LTT age patterns: A link with rifting or drifting processes?

The LTT ages produced in Morocco and its surroundings are perhaps related to cooling or heating events related to the rifting or drifting processes. Assuming that such signals were not superimposed by other processes, a clear pattern is expected to emerge from spatial and temporal distributions of the LTT ages (fig. 6.2 and 6.3). During the Triassic, two distinct rifts developed in Morocco: the Central Atlantic and High Atlas rifts. If linked to rifting processes, produced ages closed to the rifted areas should record cooling ages from Triassic to Early Jurassic times with overall older ages away from the rift zone. Indeed, it has been demonstrated that LTT ages may be affected or reset by heat fluxes in the rifted areas or their vicinity (e.g. Moore et al., 1986; Rohrman et al., 1994). Moreover, flank uplift would generate exhumation and consequently LTT systems would record cooling in the unstretched crusts along the rifted areas.

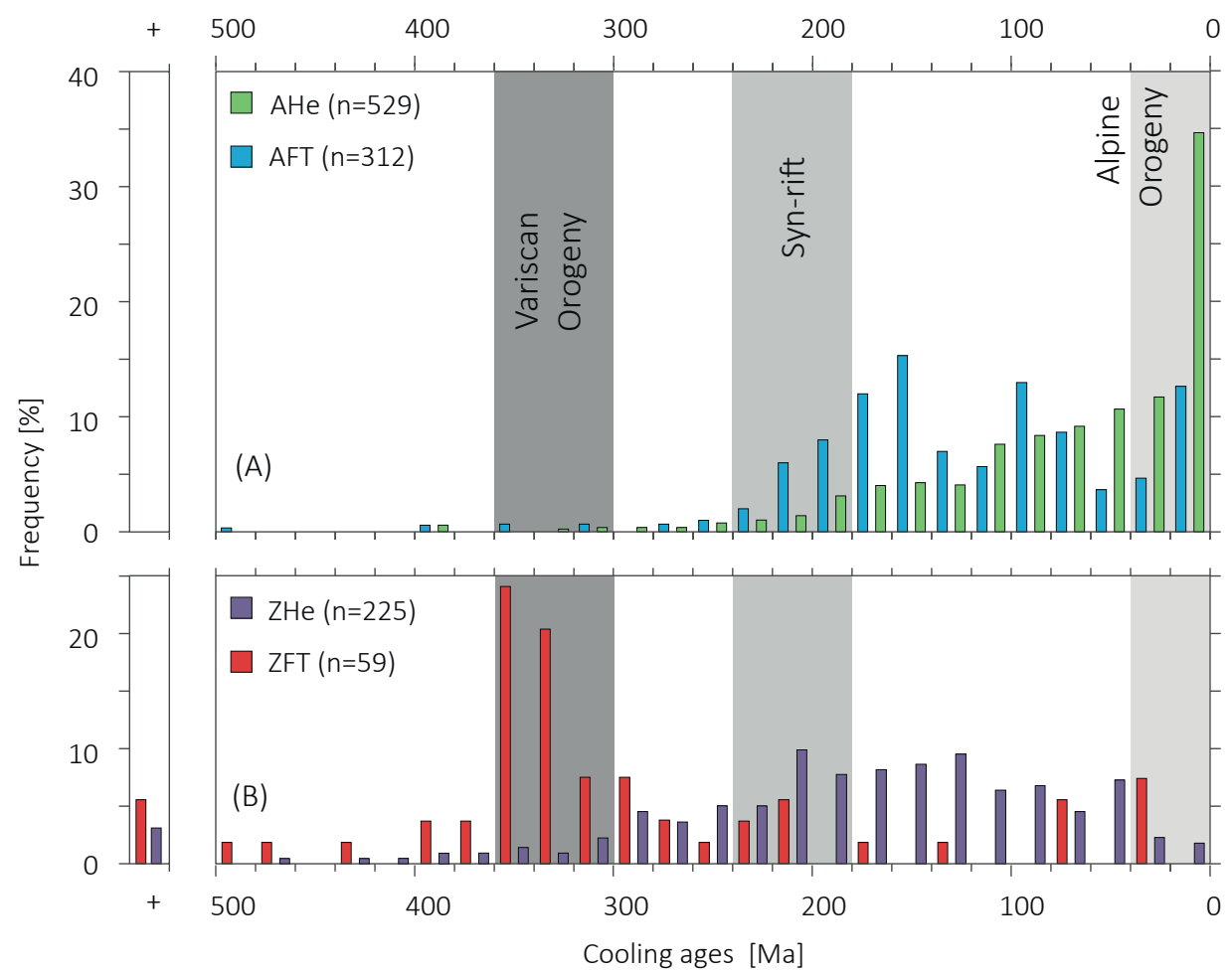

Figure 6.2. Temporal distribution of LTT ages produced in Morocco and surrounding (plotted in bins of $20 \mathrm{Myr}$ ). See all references in table 4.1. Results of thermochronology on A) apatite and B) zircon crystals. 
If LTT age patterns were linked to post-breakup uplift in the unstretched lithosphere (e.g. Leroy et al., 2008), one would expect Middle/Late Jurassic to Early Cretaceous ages along the rifted continental margin of the Central Atlantic. Away from the margin, given the assumed tectonic inactivity in the models, no particular trend or pattern is expected. Thus, the rift-related age pattern should prevail.

From 1125 LTT ages produced in Morocco and surroundings (fig. 6.2), 65\% belongs to the post-Variscan and pre-Atlas orogeny period, characterised by the pre-, syn-, and post-rift stages of both the Central Atlantic and Atlas rifts. For the remaining data, 27\% belongs to the period of Atlas deformations (ca. 40-0Ma), 5\% to the Variscan (ca. 300$350 \mathrm{Ma}$ ) and $3 \%$ is older than the Variscan. These cooling ages clearly show that widespread cooling events took place before, during, and after the rifting stages.

The spatial distribution of the cooling ages may be observed in figure 6.3 , highliting age patterns in some areas. For the AHe and AFT systems, Cenozoic ages are concentrated close to recent mountains (Rif, Atlas) or in the Canary Islands. Mesozoic and Palaeogene AHe ages were produced for all Variscan massifs. As observed for the Anti-Atlas belt in chapter 3 , there is a trend with younger AHe ages towards the northeast. In the Reguibat Shield, AFT ages are becoming significantly older (Palaeozoic) towards the northeast. This pattern is not applicable to the Anti-Atlas, as its western and eastern terminations are characterised by Permian to Jurassic AFT ages. There, AFT ages are becoming younger towards the centre of the belt.

LTT on zircons was somewhat less applied in studies conducted in Morocco (figs. 6.3C and D). While most of the ZFT ages record a Variscan signal, ZHe ages are for their majority Permian or younger. No clear age patterns are distinguished within these data sets.

We also constructed a transect running perpendicular to the Continental-Oceanic Boundary (COB), projecting orthogonally all available FT ages and the calculated (UTh)/He median ages onto it (fig. 6.4). We aim to see if there are cooling age patterns that could be explained by processes intrinsic to the Central Atlantic rifting, even though they are not visible on a map view. In that case, we should observe cooling ages of rifting ages at the continental-oceanic boundary, and older ages away from the boundary, until a threshold distance where they are not reset anymore. 

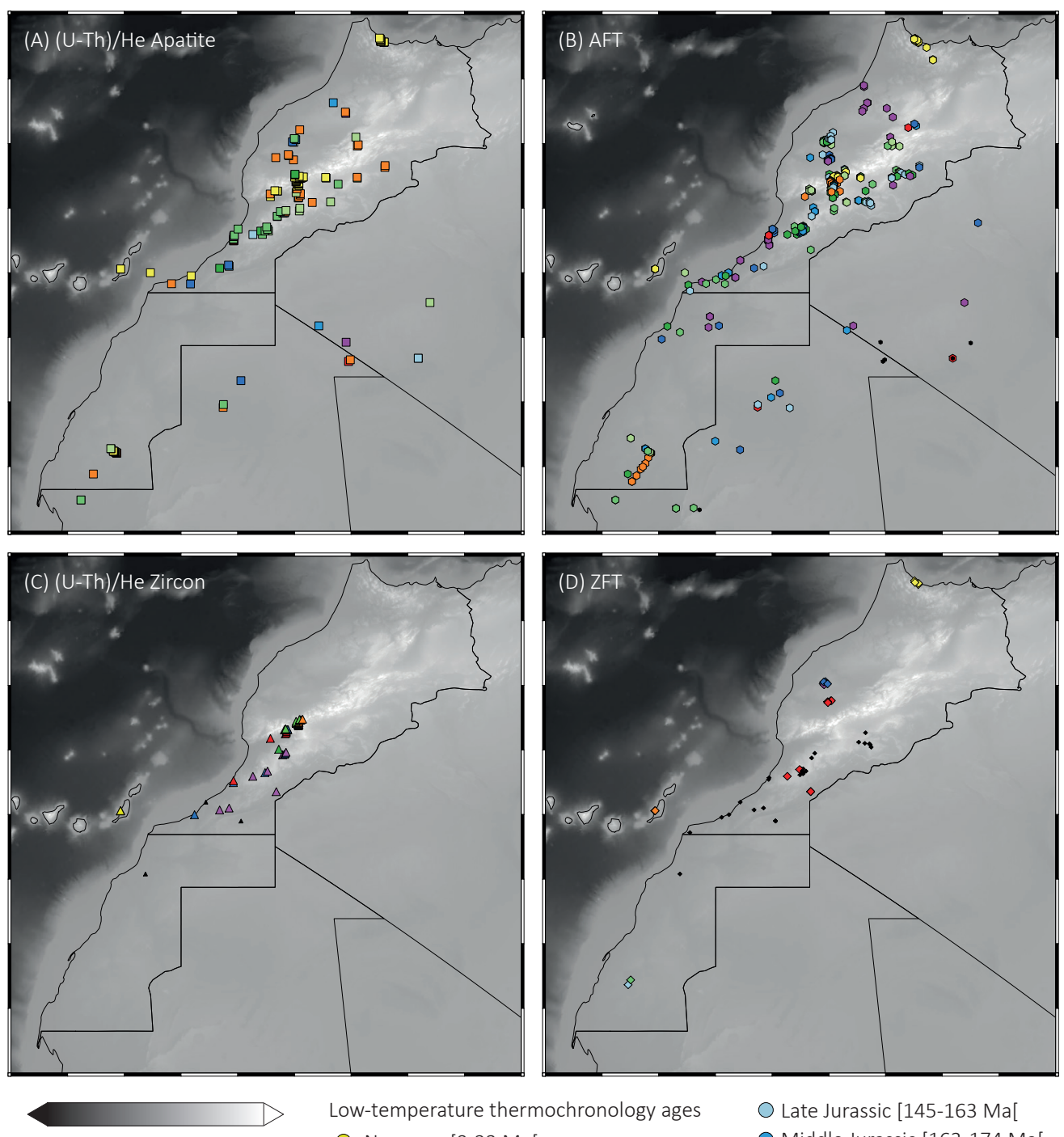

Low-temperature thermochronology ages

-5714 DEM [m] 3212

Neogene [0-23 Ma[

- Palaeogene [23-66 Ma[

Late Jurassic [145-163 Ma[

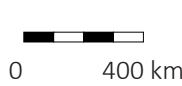

(mid-late) Late Cretaceous [66-90 Ma[

- Middle Cretaceous [90-125 Ma[

- (early) Early Cretaceous [125-145 Ma[

- Middle Jurassic [163-174 Ma[

- Early Jurassic [174-201 Ma[

- Triassic [201-252 Ma[

- Permian [252-300 Ma[

- Older $[300+\mathrm{Ma}[$

Figure 6.3. LTT cooling ages spatial pattern superimposed to the DEM (data: GEBCO_2014_1D). See complete list of references in chapter 4, table 4.1. 

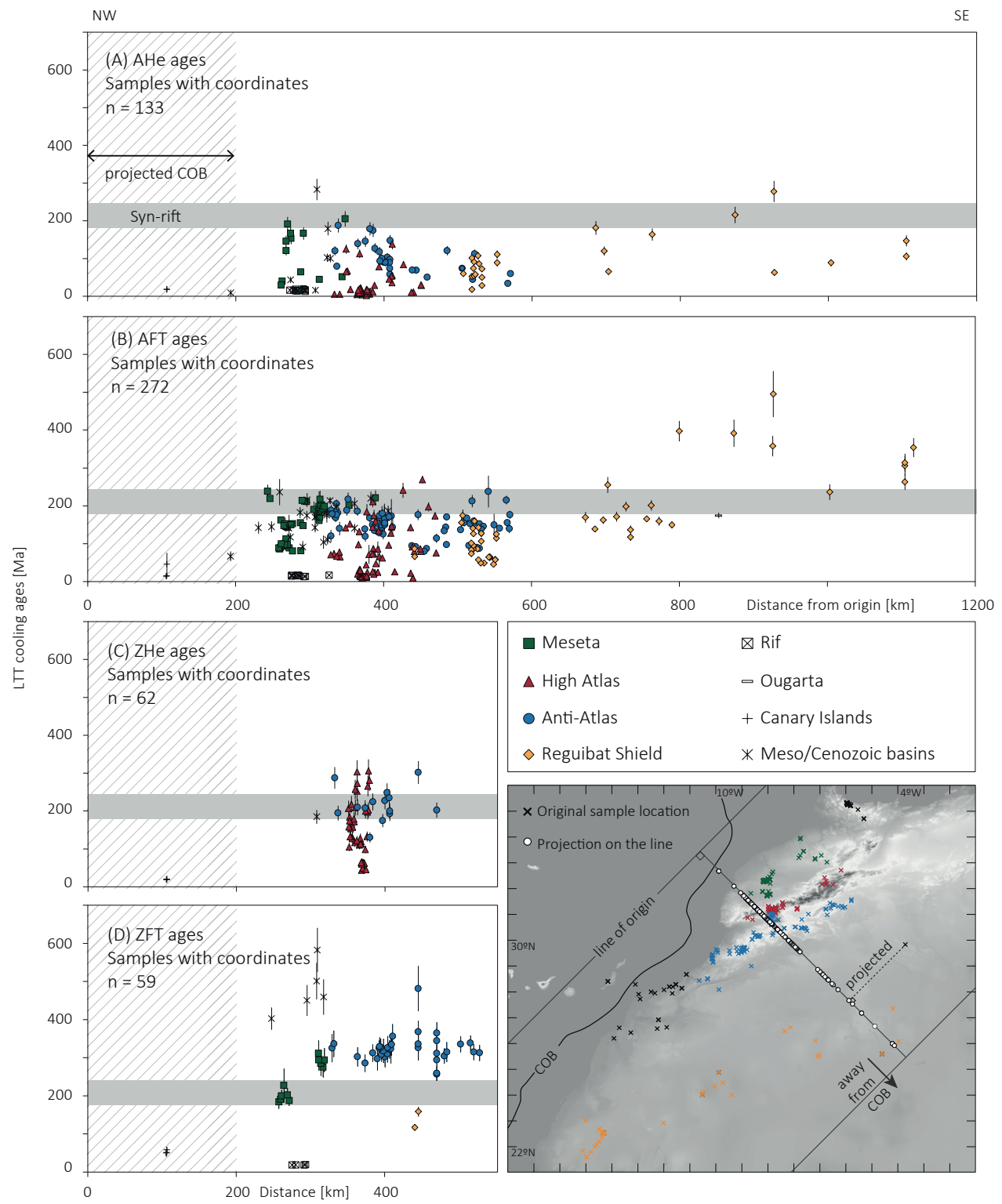

Figure 6.4. LTT ages orthogonally projected along a NW/SE trending line. The line runs perpendicular to the $\mathrm{COB}$ (orientation of a trend line offshore Morocco is $c a .47^{\circ} \mathrm{N}$ ). The position of the COB is after Miles et al., 2012. The location of the projection line on the map is for illustration purpose only. Median ages are used for AHe and ZHe. Only the produced ages of shallowest samples from boreholes were plotted. 
The AFT ages seem to become older south-eastwards away from the ContinentalOceanic Boundary (COB), as observed by Leprêtre et al. (2017). However, this trend seems to exist only because of few cooling ages produced in the Reguibat Shield. We do not observe such patterns in the other basement areas of Morocco (fig. 6.4). Similarly, the AHe, ZFT, and ZHe systems do not show clear temporal trends away from the COB, which may be due to a lack of data. Therefore, we cannot conclude here that the cooling ages and patterns are related to the rifting. It is also observed for AFT and AHe ages that few data points seem to be older than the rifting age, up to $800-900 \mathrm{~km}$ away from the COB (figs. 6.4A and B).

Additionally, it has been demonstrated for the AFT system that Mean Track Length (MTL) vs AFT age plots (fig. 6.5; sometimes called 'boomerang plots'; Gallagher and Brown, 1997) yield insights into the cooling history. Therefore, cooling events evidenced with this method (cluster of long MTL) may display a temporal link to the rifting, as exemplified in the Brazilian (Cogné et al., 2011) and Indian rifted margins (Campanile, 2007). In the Moroccan dataset however, there is no 'boomerang' curve nor a clear temporal link between long MTL (ca. 13-15 $\mu \mathrm{m}$ ) and the timing of rifting.

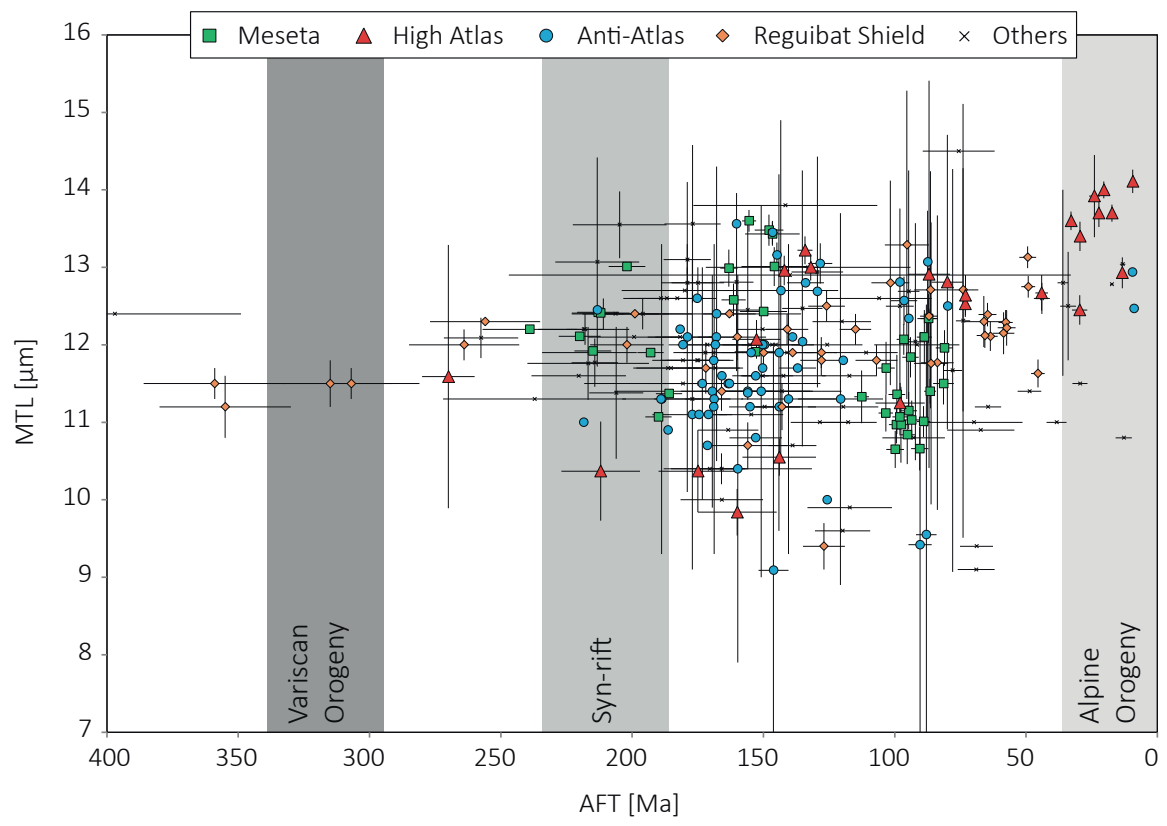

Figure 6.5. MTL vS AFT age plot for Morocco and its surroundings.

The distribution of the cooling ages without general temporal and spatial patterns, and the absence of 'boomerang curve', suggest that the processes intrinsic to rifting and/or drifting might have little to do with the vertical movement timings and patterns in Morocco or that they were superimposed by other events that occurred during the postrift stage. 


\subsection{Vertical movements: Proposed mechanisms}

Unexpected vertical movements are labelled as such because our record of the geological history is not sufficiently detailed to provide concomitant and adequate geological processes supporting their occurence. The proposed mechanisms must account for several observations: $\mathrm{km}$-scale subsidence and exhumation on a fairly large scale, not restricted to the hinterlands of the margins (e.g. exhumation of the Hoggar Massif in Algeria; English et al., 2016), and in multiple episodes (e.g. Reguibat Shield; Leprêtre et al., 2015).

Studies have argued that these episodic exhumation and subsidence events can be explained in terms tectonic plate motions and driving forces (e.g. Green et al., 2018) or lithospheric folding of the continental margin (e.g. Japsen et al., 2012). Mantle-driven dynamic topography has also been proposed as a candidate for the initiation and preservation of these vertical movements (e.g. Hoggard et al., 2016; see Müller et al., 2018, for a recent review).

Numerical modelling studies show that post-rift changes in mantle convection (e.g. Yamato et al., 2013) or thermally induced flexural response of the lithosphere (Leroy et al., 2008) eventually lead to uplift in the rifted margin hinterlands. However, these modelled mechanisms only account for the post-rift tectonics along a rifted continental margin, and thus cannot be used to test the observed pre- and syn- rift movements observed in Morocco.

In Morocco, previous authors have tentatively associated the upward movements evidenced via time-Temperature (t-T) modelling to the Variscan chain erosion for the pre-rift exhumation (e.g. Ruiz et al., 2011), to the uplifted rift shoulders for the syn-rift exhumation (e.g. Oukassou et al., 2013), and to intra-plate horizontal crustal stresses related to the South Atlantic opening and drifting for the late post-rift exhumation (e.g. Michard et al., 2008a; Ghorbal et al., 2008; Gouiza et al., 2017a).

Some authors (e.g. Frizon de Lamotte et al., 2009; Ruiz et al., 2011; Oukassou et al., 2013; Soulaimani et al., 2014) suggested that the Variscan belt was the so-called 'uplifted shoulder' of the Central Atlantic and High Atlas rifts from the end of the Triassic to the Early Jurassic. Triassic red beds in the Bechar Basin (Fabre, 2005) and offshore Atlantic margin (e.g. Ifni-1; Abou Ali et al., 2004; Hafid et al., 2006), and a lack of Triassic sediments and heating events at $200 \mathrm{Ma}$ in the western Anti-Atlas thermal history models (see argument in Soulaimani et al., 2014), are elements that support that conclusion. Moreover, rift uplifted shoulders are described as regional features with elevated areas up to one hundred kilometres away from the rift margin (e.g. Buck, 1986; Allen and Allen, 2013). Contrariwise, the absence of Triassic to Jurassic sediments in the Tindouf, Anti-Atlas, and Guir Hamada basins led Fabre (2005) to propose an isostatic rebound due to the removal of thick layers of CAMP basalts due to erosion. 
Gouiza (2011) showed with lithospheric modelling that the rifting kinematics were not sufficient to explain $\mathrm{km}$-scale vertical movements in the rift flanks during and after the rifting. Moreover, Ruiz et al. (2011; see references therein) demonstrated that the uppermost isotherms within the lithosphere of the Anti-Atlas are not much affected by thermal perturbations occurring close to the lithosphere-asthenosphere boundary or deeper. Domènech (2015) argues that the post-rift thermal relaxation of the lithosphere could not entirely explain the observed cooling in $\mathrm{t}-\mathrm{T}$ modelling results, and hence that exhumation must have occurred.

Syn-sedimentary folding and faulting documented in the Jurassic and Cretaceous of the western High Atlas suggest that regional E-W shortening supported the vertical movements (Bertotti and Gouiza, 2012). Other non-Atlasic compressional structures have been observed onshore in the Missour basin (Beauchamp et al., 1996), EssaouiraAgadir basin (Fernández-Blanco and Gouiza, 2015), and Central High Atlas (Calvin et al., 2017). Offshore, in the passive margin, Late Cretaceous compressional structures have also been interpreted on seismic profiles, near Safi (Dunlap et al., 2013), Essaouira (Neumaier et al., 2015), and Tan-Tan (Abou Ali et al., 2004). However, they have been attributed to the Atlasic shortening. Shortening directions inferred in the abovementioned studies are between E-W and NNW-SSE. In the Tarfaya basin, JurassicCretaceous "tectonic movements" were described and attributed to the motions of an east-bounding fault (Choubert et al., 1966). This fault was said to be a tectonic limit between the Anti-Atlas and the basin. Nonetheless, it is hard to resolve if this inferred post-rift and non-Atlasic shortening is the cause of the vertical movements or merely the consequence of adjacent areas being uplifted by other mechanisms.

Based on a careful analysis of the terraces in the Anti-Atlas coastal area, Westaway et al. (2009) concluded that the observed Neogene uplift was climate driven. In the interior of the Anti-Atlas and High Atlas, other authors tentatively associated the uplift to a large mantle anomaly (Teixell et al., 2003; Oukassou et al., 2013), resulting from the Moroccan Hot Line (Arboleya et al, 2004; Teixell et al., 2005; Missenard, 2006; Babault et al., 2008; Frizon De Lamotte et al., 2009).

Downward movements, also obtained with t-T modelling, were solely explained in terms of sedimentation, of which deposits are now eroded from the sampled basement areas (e.g. Ghorbal et al., 2008; Leprêtre et al., 2013). To evidence that modelled heating events can be described in terms of sedimentary loading, Sehrt (2014) calculated subsidence rates from $\mathrm{t}-\mathrm{T}$ models converted to depth. He then made a comparison to rates obtained from seismic interpretations in the north Tarfaya basin and observed that they were comparable. 
6.5. Characteristics of the upward movements: Insights from this Thesis

\subsubsection{Link between offshore rifted and onshore non-rifted domains}

Five cross-sections, perpendicular to the Moroccan rifted margin across offshore and onshore Atlantic basins, are compared to the present-day Sidi Ifni transect (chapter 2). To compare the geological evolutions, we use published $\mathrm{t}-\mathrm{T}$ models and subsidence curves along these transects (fig. 6.6).

The Doukkala, Rabat Offshore, and Essaouira transects (figs. 6.6A, B and C, respectively) all depict a Triassic or Jurassic unconformity over the basement, onshore as well as offshore, and a relatively thick Mesozoic sedimentation (up to 2-3 km). The Upper Cretaceous reflections are truncated at the present-day continental shelf edge (Hafid et al., 2008), which is attributed to Cenozoic tectonics. In the Meseta and High Atlas, LTT studies and $\mathrm{t}-\mathrm{T}$ models have documented a similar kinematic evolution of vertical movements (e.g. Ghorbal et al., 2008; Domènech et al., 2016). The presently outcropping Variscan rocks in the Meseta were close to the surface during the Permian/Late Triassic, followed by subsidence until the Middle Jurassic, exhumation in the Late Jurassic/Early Cretaceous, renewed subsidence during the Late Cretaceous and a final exhumation in the Cenozoic.

Both Anti-Atlas sections (figs. 6.6D and E) show a fairly thick Mesozoic package (between 2 and $5 \mathrm{~km}$ ) at the western flank of the belt, with two to three unconformities: one following the Variscan folding, one within the Jurassic, and one at the base of the Cenozoic. In the Anti-Atlas, Gouiza et al. (2017a) and this study document a similar thermal evolution, although different from the one described in the Meseta (e.g. Ghorbal et al., 2008).

The differences in post-Variscan thermal evolutions of the Meseta/High Atlas and AntiAtlas highlight several shifts of source areas for the sediments delivered to the Atlantic and coastal basins between the Middle and Late Jurassic and between the Early and Late Cretaceous. 

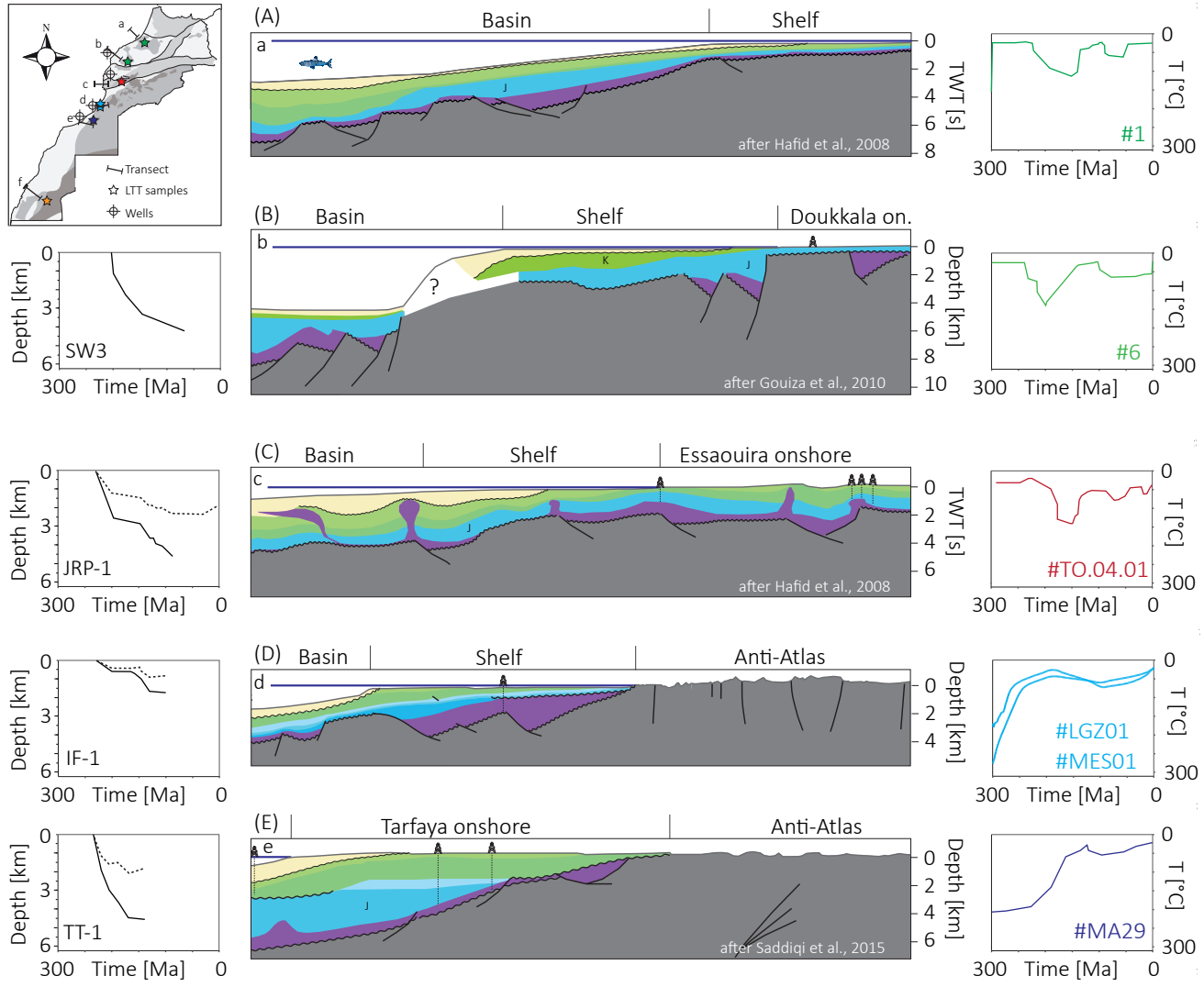

Backstripping results (in $\mathrm{km}$ ) - total subsidence -..... tectonic subsidence
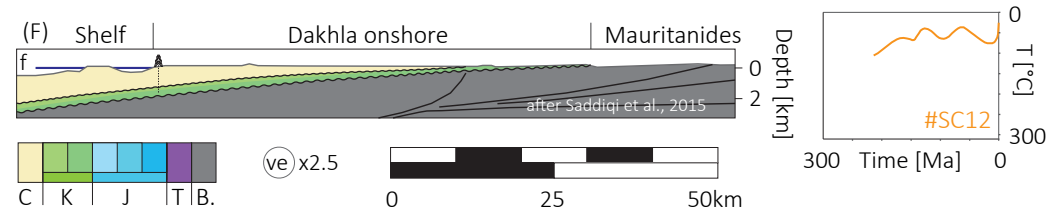

Figure 6.6. Present-day 2D architecture of the Moroccan passive margin (central panels), selected subsidence and backstripping curves (left panels), and t-T modelling (right panels) results. A to F) Rabat, Doukkala, Essaouira, Sidi-Ifni, North Tarfaya, and Dakhla transects, respectively. Note that cross-sections ' $a$ ' and ' $C$ ' are in time. See location map for orientation. C: Cenozoic; K: Cretaceous; J: Jurassic; T: Triassic; B: Basement (Palaeozoic and Precambrian). The letters "J" and " $\mathrm{J}$ " are shown on the sections only if the Jurassic or Cretaceous are locally undifferentiated. The $t$-T best-fit results of samples 1/6, T0.04.01 and MA29 are from Ghorbal et al., 2008, Ghorbal, 2009 and Sehrt et al., 2017a, respectively. The $t-T$ weighted average results of samples LGZO1/MESO1 and SC12 are from the present work and Leprêtre et al., 2015, respectively. The subsidence curves from wells SW3 (synthetic), JRP-1 and IF-1/TT-1 are from Gouiza et al., 2010, Bouatmani et al., 2007 and Gouiza, 2011, respectively. 
Finally, the Dakhla section (fig. 6.6F) shows that no sediments are preserved prior to the Early Cretaceous (Ranke et al., 1982; Saddiqi et al., 2015) west of the Mauritanides/Reguibat Shield. The thickness of the Cretaceous deposits may have reached $2 \mathrm{~km}$, unconformably overlain by Palaeocene sediments (Ranke et al., 1982). The documented kinematic evolution (e.g. Leprêtre et al., 2015) is also different from those of other segments, showing subsidence from the Permian to the Triassic and exhumation from Jurassic onwards for most of the Reguibat Shield, with locally shorter and milder exhumation and subsidence episodes (e.g. Leprêtre et al., 2015).

The insights obtained from the cross-sections, subsidence analyses, and onshore thermal history give us the opportunity to link the onshore and offshore domains. It is clear that strong exhumation episodes in the hinterland are expressed in the sinks by normal to excessive subsidence rates, as if it was echoing a flexural response of the crust or lithosphere. The link between exhumation and excessive subsidence episodes may be evidenced during the Triassic in the Essaouira and north Tarfaya transects (figs. 6.6C and E), during the Early to Middle Jurassic in the Doukkala (fig. 6.6B) and north Tarfaya transects, and during the Early Cretaceous in the Essaouira transects (Bertotti and Gouiza, 2012). Moreover, in all transects except the Dakhla one, subsidence recorded by LTT and $\mathrm{t}-\mathrm{T}$ modelling can be linked to sediments preserved in the offshore and coastal basins. It is therefore not surprising to observe sediments truncated in the shelf or coastal domains (e.g. Late Cretaceous in the Meseta and Reguibat Shield regions and Early Cretaceous along the western Anti-Atlas). Finally, it is worth noting that the nonpreserved sediments may not be linked to one specific hinterland kinematic. Instead, they are linked to stable areas during the Permian, Mesozoic subsidence and exhumation episodes in the Dakhla transect (fig. 6.6F), and exhumation in the Rabat (fig. 6.6A) and Essaouira transects during the Late Cretaceous/Palaeogene transition.

Furthermore, we propose that the observed syn-rift exhumation is not linked to rift shoulder uplift, for two reasons: i) the Permian to Jurassic exhumation started in the Anti-Atlas and Reguibat Shield before the initiation of rifting (see chapter 5); and ii) Late Triassic sediments are well represented east of the Atlantic faults in many basins (e.g. Rabat: Hafid et al., 2008; Doukkala: Gouiza et al., 2010; offshore Sidi Ifni: Chapter 2) and south to the rift related faults (Souss basin: Samaka and Bouhaddioui, 2003). This process has previously been discarded for the post-rift km-scale exhumation in elevated continental passive margins, as the area undergoing exhumation extends far beyond the scale of flank rift uplift (e.g. Japsen et al., 2012; Green et al., 2018). In general, the role of the faults seems to be limited to the subsidence episodes. 


\subsubsection{Exhumation and subsidence wavelengths}

The vertical movement half wavelengths can be estimated from the evolution of subsidence and exhumation observed along a cross-section trending perpendicular to the strikes of the Jebilets Massif, High Atlas, Anti-Atlas, and Reguibat Shield (fig. 6.7). The half wavelengths, expressed as the distance between null points, are between ca. 50 and $600 \mathrm{~km}$ for the exhuming domains, and ca. 40 and $200 \mathrm{~km}$ for the subsidence wavelengths.

The Tindouf basin remains fairly unconstrained in terms of vertical movements and therefore these wavelengths should be carefully considered, especially before the Late Cretaceous. Nevertheless, the longest half wavelength is observed during the syn-rift stage for the Reguibat Shield to Anti-Atlas area. In general terms, the half wavelengths shorten towards the north, up to the Atlantic basin, where subsidence prevails in all illustrated periods. The vertical movements favoured the transgression or regression of the sea, with positive feedback on the associated motion rates, assuming that these movements were not triggered by sea level changes.

As a reminder, our results from the Anti-Atlas in chapter 3 suggested pre-, syn-, and post-rift exhumation episodes with an inland half wavelength reaching over $600 \mathrm{~km}$. The other half wavelengths (fig. 6.7) appear, however, fairly "small" to be explained by mantle driven dynamic topography (wavelengths of $>1000$ km; e.g. Müller et al., 2018).

Proposed mechanisms in Morocco for the positive and negative vertical movements, as reviewed in the previous sections, are large-scale processes (see Teixell et al., 2009). These processes may act at wavelengths from one to several hundreds of kilometres (e.g. Şengör, 2003; Babault et al., 2008; Frizon de Lamotte et al., 2009). The proposed processes for the exhumation episodes with matching half wavelengths are rift flank uplifts (however discarded in the previous section), mantle driven doming, lithospheric flexure, crustal-scale folding, and erosional unloading. For the subsidence episodes, while sedimentary loading was the only process proposed, tectonic subsidence regimes have likely enhanced the downward movements. These may be explained in terms of crustal thinning (rift zone), thermal cooling (old rift), lithospheric flexure, and crustalscale folding (see Teixell et al., 2009). 

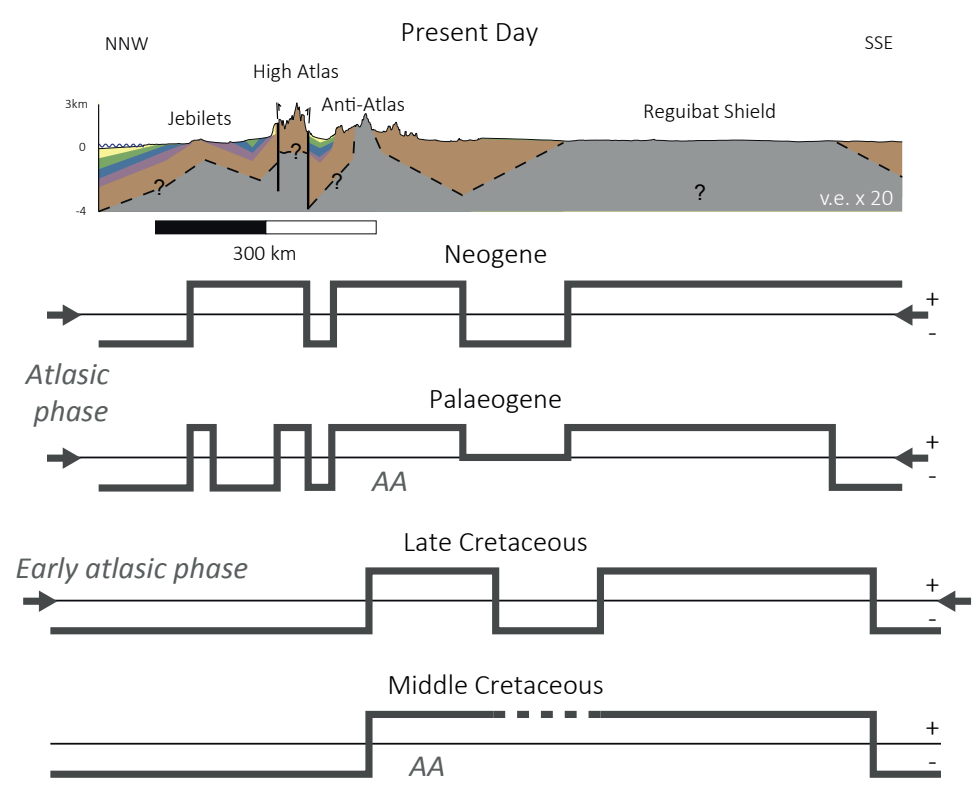

Late Jurassic/Early Cretaceous
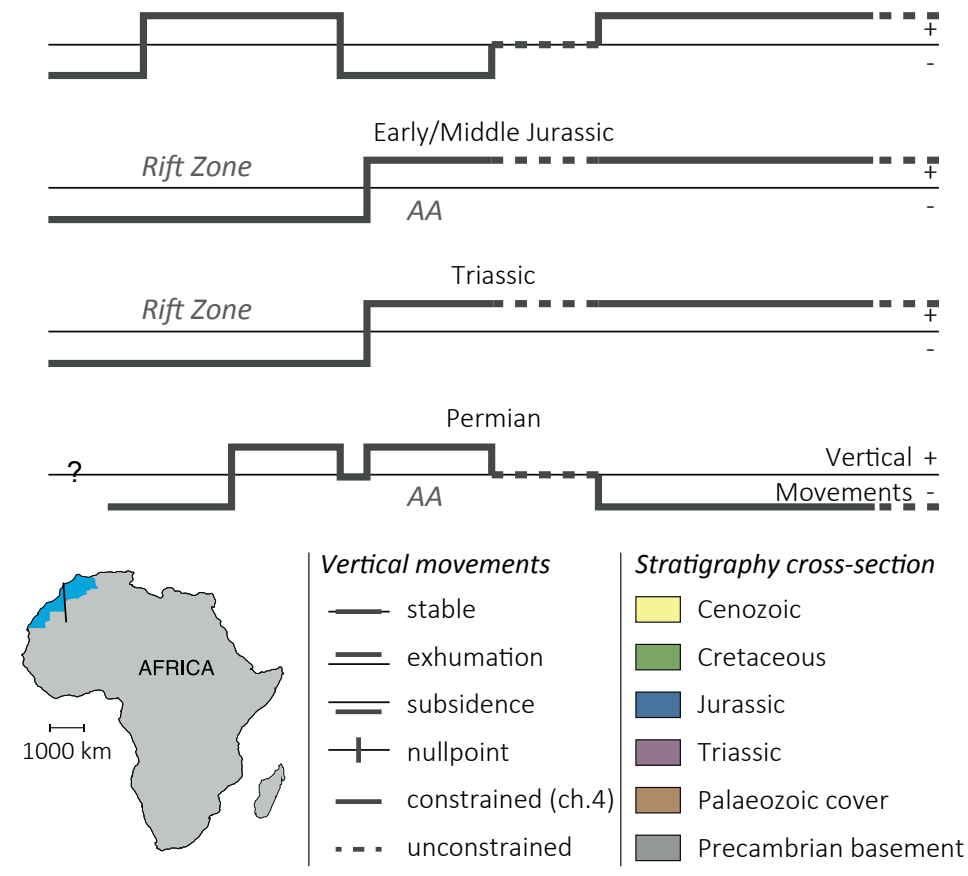

Figure 6.7. Highly schematic NNW-SSE evolution of vertical movements as evidenced by LTT and $t$-T modelling (see chapter 4). 


\subsubsection{A semi-quantitative comparison of vertical movement rates}

Positive and negative vertical movements may be caused by numerous mechanisms were review in Teixell et al. (2009). One important aspect of these movements, which in turn also allows for comparison with our results, is their motion rate. The vertical movement rates considered in the following tables are from the chapter 4 of this Thesis (tables 6.1 and 6.3) and from literature (tables 6.2 and 6.4). In the latter, we selected rates with well-constrained triggering and/or supporting mechanisms.

The calculated exhumation rates in chapter 4 are characterised by mean values between 0 (0.0002) and $0.11 \mathrm{~km} / \mathrm{Myr}$, with an overall mean of $0.034 \mathrm{~km} /$ Myr. Relatively high exhumation values are between ca. 0.09 and $0.2 \mathrm{~km} / \mathrm{Myr}$. When compared to exhumation rates in the literature, the obtained rates are comparable to erosional unloading, mantle upwelling, rift flank uplift, magmatic arc, orogens, and crustal folding (table 6.2; see reference therein). For obvious reasons we rule out magmatic arc as a candidate for the observed movement and the rift flank uplift was previously discarded (see argument in a section 6.5.1). Values for forebulge and core complex settings have been documented with rates $>0.5 \mathrm{~km} / \mathrm{Myr}$ (e.g. Michel et al., 2017), and are thus consider as unlikely candidates.

However, it is worth noting that the presented values are not only dependent on the tectonic processes, but also on the erodibility of the rocks at the surface and on the climate. The last two parameters are not constrained in this Thesis, and it is hence difficult to fully discriminate the exhumation mechanisms solely based on the rates.

The subsidence rates calculated from now eroded basins are compared to total subsidence rates in known tectonic settings (tables 6.3 and 6.4). The calculated subsidence rates are characterised by mean values between $0(-0.0005)$ and -0.31 $\mathrm{km} / \mathrm{Myr}$, with an overall mean of $-0.016 \mathrm{~km} / \mathrm{Myr}$. Relatively high subsidence values are between ca. 0.05 and $0.09 \mathrm{~km} / \mathrm{Myr}$. When compared to exhumation rates in the literature, the obtained rates are comparable to rates observed for thermal subsidence and crustal folding (table 6.4; see reference therein). They are however lower by one to two orders of magnitude than rates documented for basins developing in rift zone and foredeep settings.

Even though these basins have developed as epicontinental basins in unstretched continental crust, their proximity with the continental margin of the Triassic rifts suggests that thermal subsidence might be a good candidate for the downwarps. Cambrian rifting structures, which affected the Anti-Atlas, High Atlas, and coastal Meseta (e.g. Javier Álvaro, 2013), characterises the basement of the Central Atlantic passive margin hinterlands as an old rift. 


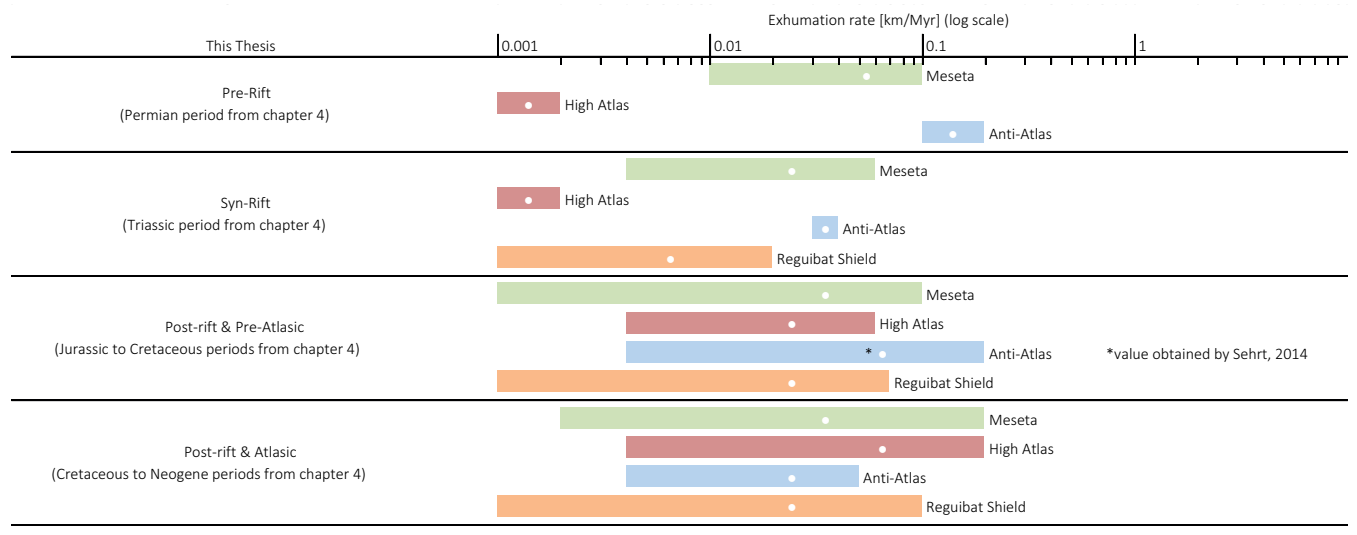

Table 6.1. Exhumation rates from chapter 4 of this Thesis, for which the mechanisms are unknown. The white dots show the mean average exhumation rates.

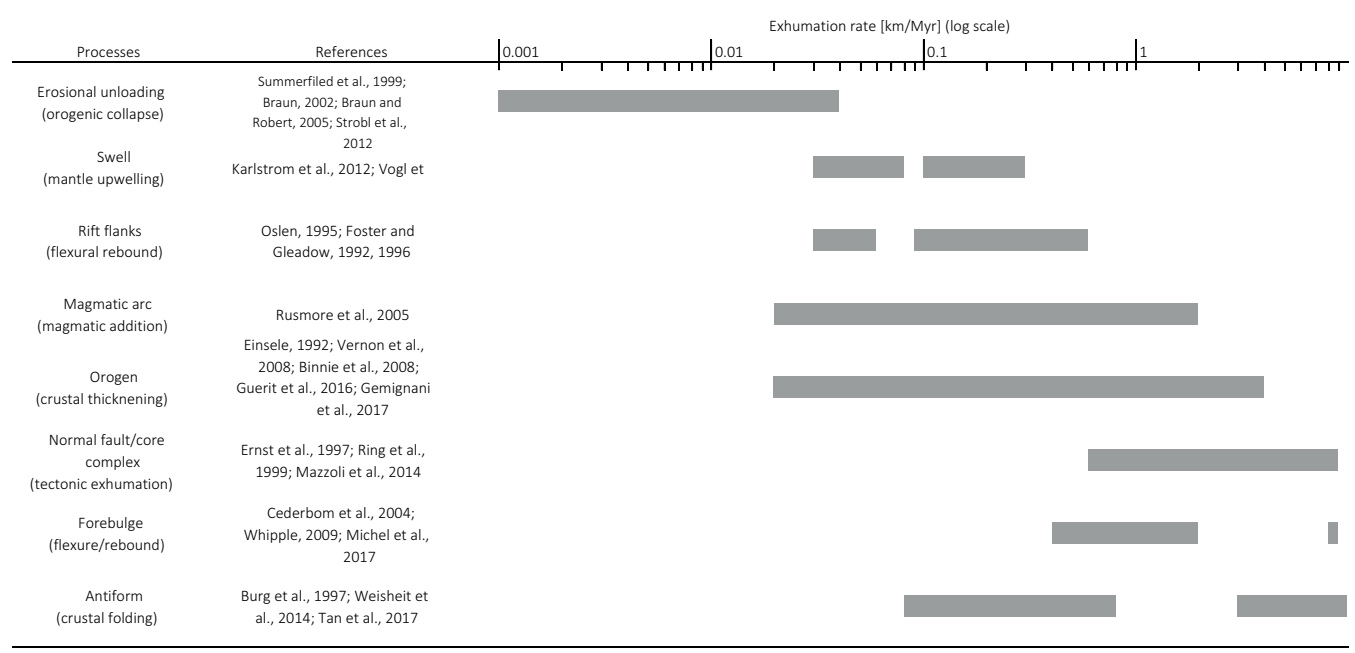

Table 6.2. Exhumation rates from literature where the mechanisms are known (see references therein).

The crustal folding is also a suitable candidate, given that syn-sedimentary compressional structures were observed in many preserved basins (see section 6.4). Moreover, the relatively high exhumation rates are comparable to crustal folding rates. Together, they support the idea that large-scale crustal folding affected the study area during the syn- and post-rift stages. 


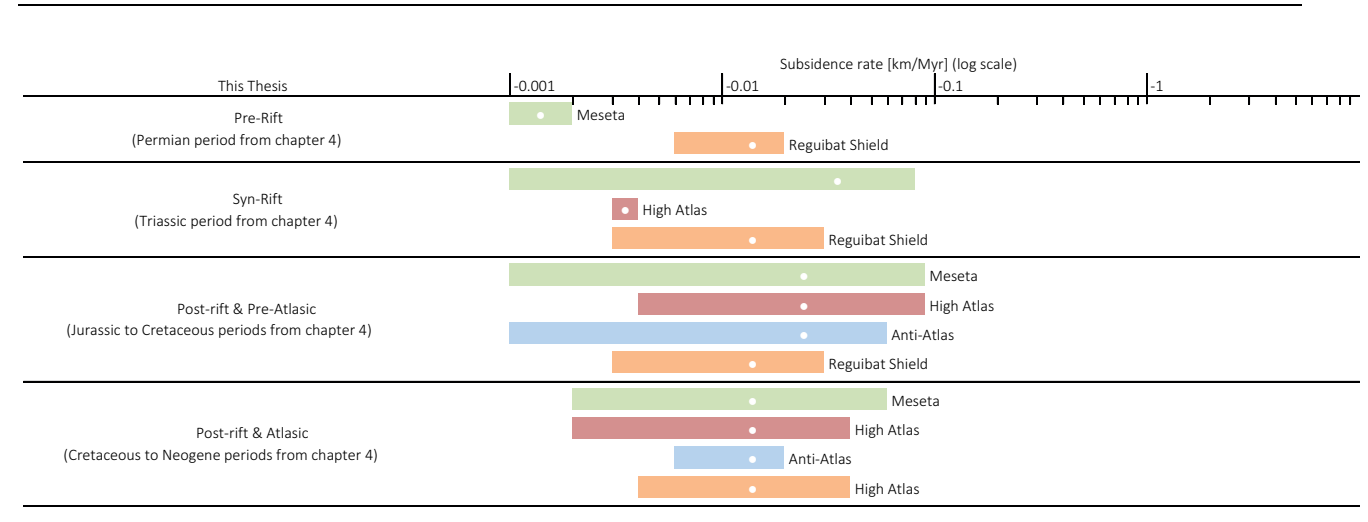

Table 6.3. Subsidence rates from chapter 4 of this Thesis, for which the mechanisms are unknown. The white dots show the mean average subsidence rates.

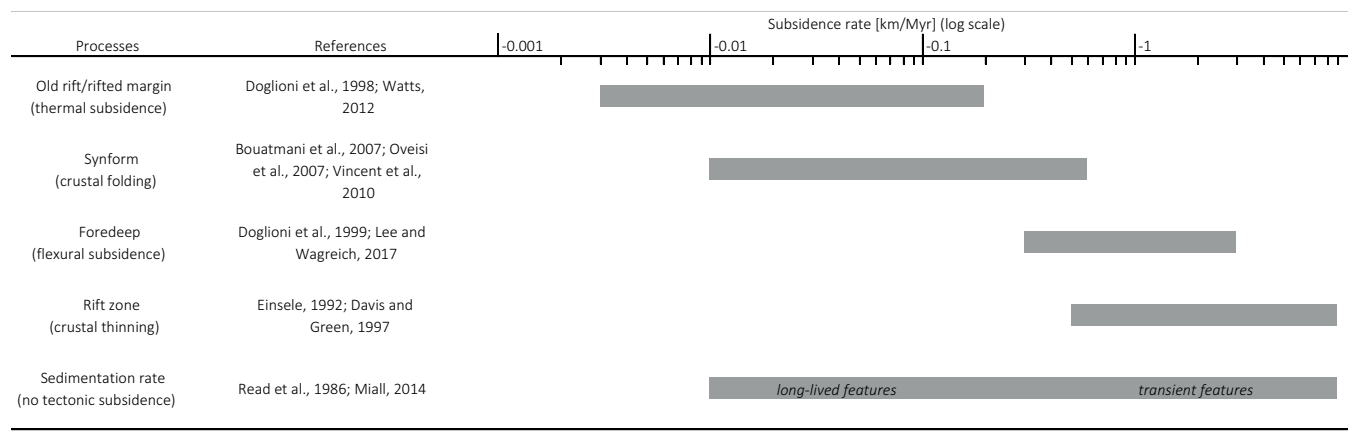

Table 6.4. Total subsidence rates (i.e. including sedimentation) from literature where the mechanisms are known (see references therein).

Nevertheless, caution should be used with such comparison, as it was very recently shown by Green et al. (2018) that the thermal histories derived from LTT might be erroneous. The models often show continuous cooling and heating phases (as exemplified for Morocco in this Thesis), while the sedimentary records suggest in general a rather episodic evolution. Therefore, the obtained rates in chapter 4 may have to be corrected in this regard, leading to higher rates for narrower periods. 
6.6. Compilation of tectonic, climatic, and eustatic proxies vs. this Thesis

We compiled different tectonic, climatic, and eustatic proxies into figure 6.8 , to qualitatively discriminate these processes. We observe that the exhumation episodes that marked the Moroccan geological history are caused by a combination of factors including landmass position (paleo-latitude) and hence climate, peneplanation of the Variscan chain (erosion>uplift), thermal mantle anomaly (CAMP, PAAP, Cenozoic volcanism), global sea level drop, and far-field stress.

There is a match between tectonic events and calculated volumes of eroded material (from chapter 4; figs. 6.8A and B). As the Atlas orogeny evolves, these volumes increase, which could also be linked to Tertiary volcanism. The observed Early/Middle Jurassic enhanced erosion starts at the end of the Central Atlantic and Atlas rifting, concomitantly to the CAMP dykes intrusion. Two long CAMP related dykes are present in the Central Anti-Atlas (Foum Zguid and Igherm dykes; e.g. Silva et al., 2010; Touil et al., 2008), which could explain a domal uplift of the Anti-Atlas, supposedly due to a CAMP related mantle anomaly. Changes in sea level correlate well with the calculated volumes of eroded material (fig. $6.8 \mathrm{C}$ ), as rises and drops are matching low and high erosion, respectively. Paleo-latitudes are a key factor in paleo-climates studies (van Hinsbergen et al., 2015), although they cannot directly be used as paleo-climate proxies. However, since the Permian, the highest latitudes (fig. 6.8D) were reached during the Jurassic and the Paleogene/Neogene, which are the periods characterised in our model by enhanced erosion in the Anti-Atlas and Reguibat Shield.

We also compare full spreading rates at the Atlantic Mid Oceanic Ridges (MOR; fig. 6.8E) to the obtained eroded material volumes (chapter 4), as one may expect enhanced erosion during or immediately after a peak in these accretion rates. We observe two peaks for the Central Atlantic MOR (around $150 \mathrm{Ma}$ and from $40 \mathrm{Ma}$ onwards) and one significant peak for the South Atlantic MOR (from ca. 110 to $80 \mathrm{Ma}$ ). However, we cannot establish a direct link with the increase in volumes of eroded material.

Finally, we used the dynamic topography model of Barnett-Moore et al. (2017), which was applied to North Africa for the Mesozoic-Cenozoic period. From 230 to ca. $80 \mathrm{Ma}$, the northernmost and southernmost points of Morocco have experienced a very similar evolution, but their evolution diverge from $80 \mathrm{Ma}$ onwards (fig. 6.8F). Indeed, after 80 Ma the south part experienced an increased dynamic topography of up to $200 \mathrm{~m}$ while the north part shows a negative dynamic topography. 


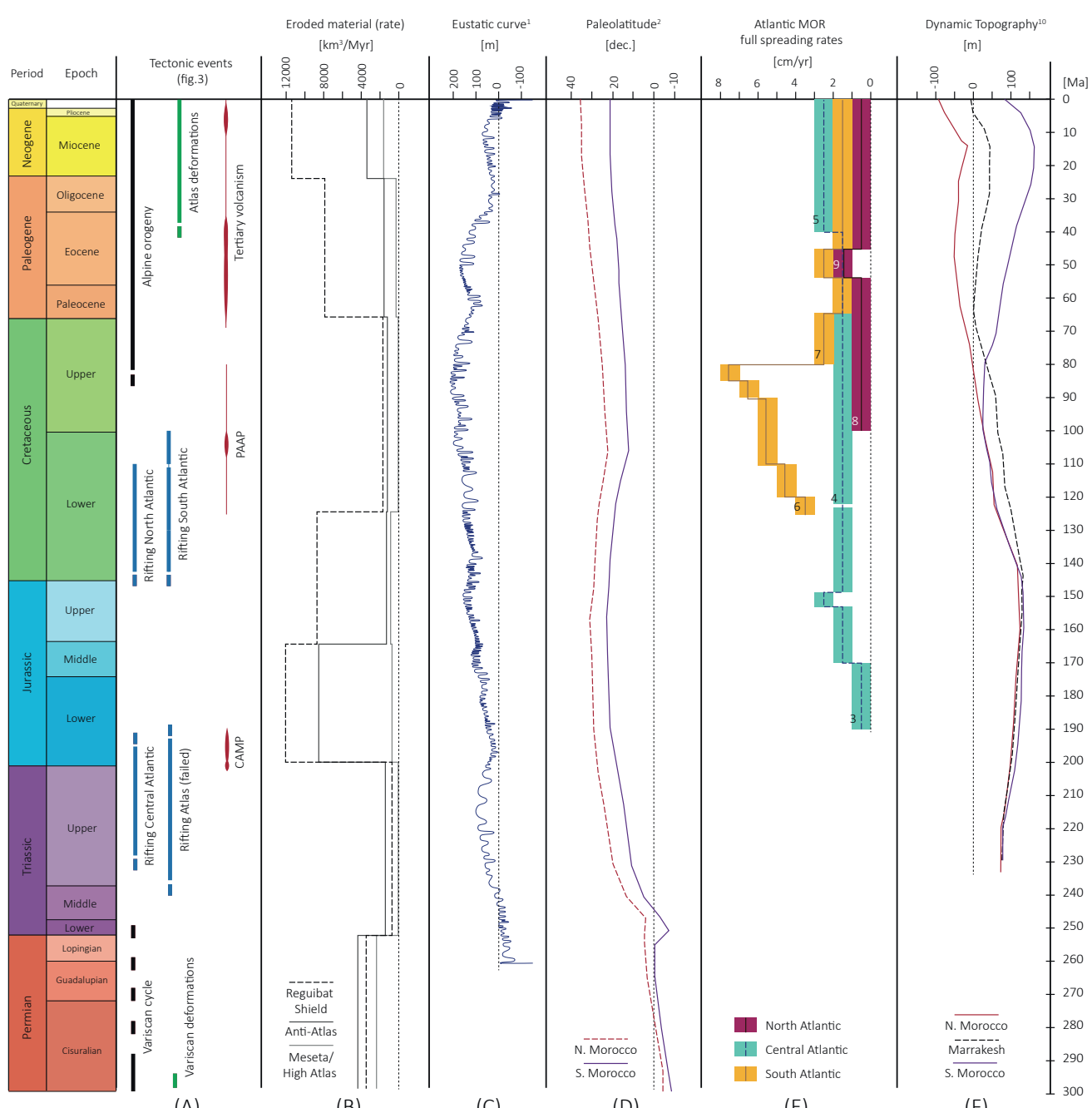

(A)

(B)

(C)

(D)

(E)

(F)

Figure 6.8. Permian to Neogene evolution of A) major tectonic events in the Atlantic realm and Morocco (see references in chapter 1); B) volumes of eroded material per million year for the Meseta/High Atlas, Anti-Atlas, and Reguibat Shield (chapter 4); C) see level ( ${ }^{1}$ Snedden and Liu, 2010); D) paleo-latitude of two points in Morocco (after maps of ${ }^{2}$ Scotese, 2012); E) Full Mid Oceanic Ridge (MOR) spreading rates (after ${ }^{3}$ Labails et al., 2010; ${ }^{4}$ Müller et al., 2008; ${ }^{5}$ Schettino et al., 2016; ${ }^{6}$ Granot and Dyment, 2015; ${ }^{7}$ Nurnberg and Müller, 1991; ${ }^{8}$ Mosar et al., 2002; ${ }^{9}$ Torsvik et al., 2001); F) and dynamic topography of three points in Morocco (from the GPlates website, after model Cls of ${ }^{10}$ Barnett-Moore et al., 2017) 
Enhanced erosion during the Jurassic was driven by the positive dynamic topography, CAMP dyke emplacements, and onset of seafloor spreading; three processes that may be linked. Furthermore, a low sea level and a position at a relatively similar latitude as present-day may explain this exhumation event. At the contrary, when the volumes of eroded material are the lowest during the Late Cretaceous, the period is characterised by a high sea level, small values of dynamic topography, and lower paleo-latitude than the Jurassic and Palaeogene periods. The occurrence of the PAAP at ca. $100 \mathrm{Ma}$ (e.g. Maton and Jébrak, 2009), assuming an associated mantle anomaly, shows that mantle anomalies may not always trigger large-scale denudation events, but that other circumstances have to be gathered.

\subsection{Conclusions}

The different compilations and comparisons of data from this Thesis and from the literature let us speculate on the processes driving the vertical movements, remaining however, not fully ascertained. Rifting LTT patterns, if they existed, have clearly been overprinted by post-rift events, without a frank temporal or spatial configurations. Some LTT ages retain a Variscan signal, especially on zircon crystals, and the AHe system seems particularly well suited to study the Atlasic orogen. However, the AFT system shows widespread ages from Palaeozoic to Neogene.

The proposed mechanisms in Morocco account for local to regional observations. In general, however, they do not account for large scale and more general observations (km-scale subsidence and exhumation, fairly large scale, not restricted to the hinterlands of the margins, and multiple episodes), which we consider as a requirement to explain these movements. On the other side, recent studies assuming mantle driven dynamic topography as an underlying cause for both upward and downward movements (e.g. Müller et al., 2018) seem to not take into account the local and regional observations.

The comparison of the Sidi Ifni transect to other transects along the rifted margin of Morocco highlights changes in the architecture of the offshore Mesozoic deposit. We show here that the above-defined segments along the margin underwent significantly different kinematic evolutions, with specific vertical movement patterns and links between the hinterland and basins.

Finally, the wavelength evolution and motion rates suggest large-scale crustal folding, affecting both exhuming and subsiding domains with higher-frequency where the continental lithosphere was affected by Cambrian and/or Triassic rifting. Furthermore, we assume that it is the combination of the large-scale crustal folding, mantle-driven dynamic topography, to some extent, and thermal subsidence, superimposed to climate, sea level and erodibility of the exposed rocks (see Flowers and Ehlers, 2017), that contributed to the vertical movement timing, patterns, and amplitudes. 
Acknowledgements: Giovanni Bertotti is thanked for the many geological discussions. Kevin Bisdom is thanked for proofreading this chapter. Pierre-Olivier Bruna is thanked for proofreading the figures and tables. 



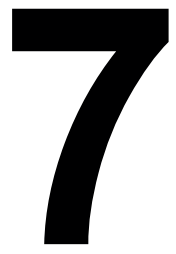

Conclusion 


\subsection{Summary of this Thesis}

Throughout this Thesis, we have investigated the vertical movements that occurred in the geological past of Morocco and its surroundings.

The transition area between generally subsiding domains and mostly exhuming domains has been described via the evolution of the Sidi Ifni transect, running across the rifted continental margin (chapter 2). Low-temperature thermochronology data from the Anti-Atlas coastal area document a km-scale exhumation between the Permian and the Early/Middle Jurassic. The related erosion fed sediments to the subsiding Mesozoic basin to the northwest. Basement rocks along the transect were subsequently buried between the Late Jurassic and the Early Cretaceous. From late Early/Late Cretaceous onwards, rocks present along the transect were exhumed to their present-day position.

The post-Variscan thermal and geological history of the Anti-Atlas belt was constrained with transects constructed along strike of the belt (chapter 3 ). The initial episode occurred in the Late Triassic and led to a $\mathrm{km}$-scale exhumation of crustal rocks by the end of the Middle Jurassic. The following phase resulted in basement subsidence and occurred during the Late Jurassic and most of the Early Cretaceous. The basement rocks were then slowly brought to the surface after experiencing a $\mathrm{km}$-scale exhumation throughout the Late Cretaceous and the Cenozoic. The exhumation episodes extended into the interior of the African tectonic plate, perhaps beyond the sampled belt itself.

The exhumation rates and material eroded flux from the hinterlands of the Moroccan rifted margin have been quantified since the Permian (chapter 4). High denudation rates comparable to values typical of rift flank, mantle driven doming, or structural (faulting/folding) uplifts. These were obtained in the Anti-Atlas during the Early to Middle Jurassic and in the High Atlas and Rif during the Neogene. Exhumation rates for other periods in the Meseta, High-Atlas, Anti-Atlas, and Reguibat shield average around normal denudation values. Periods of high production of sediments in the investigated source areas are the Permian, the Jurassic, the Early Cretaceous, and the Neogene.

The Phanerozoic evolution of source-to-sink systems in Morocco and surroundings were illustrated in several maps (chapter 5 ). Substantial shifts in source areas were evidenced between the Anti-Atlas and Meseta domains from the Middle to Late Jurassic and between the Meseta and Anti-Atlas from the Early to Middle/Late Cretaceous.

Finally, the mechanisms responsible for the onset and upkeep of the km-scale unpredicted vertical movements have been reviewed (chapter 6). We proposed that a combination of the large-scale crustal folding, mantle-driven dynamic topography, and thermal subsidence, superimposed to changes in climates, sea level and erodibility of the exposed rocks, contributed to the vertical movement timing, patterns, and amplitudes observed in Morocco and its surroundings. 


\subsection{Further investigation}

\subsubsection{Low-temperature thermochronology}

There remain many places in Morocco and in its surrounding where Low-Temperature Thermochronology (LTT) studies could be undertaken. For example, the basement outcrops in the Ougarta, Béchard, and Haut Plateaux regions have very little to no LTT data.

As we have conducted for the Anti-Atlas, an along strike LTT transect of the High Atlas would surely bring insights into the evolution of this inverted rift. Precambrian outcrops may be sampled in the east of Morocco or in Algeria. The western termination of the Massif Ancien in the western High Atlas has not yet seen a study applying the AFT/AHe couple.

Neighbouring countries (Algeria, Mali, and Mauritania) have fairly small databases of LTT ages. Many opportunities exist, in terms of exposure of crystalline basement, to explore the vertical movements ever further away from the rifted margin.

Cores from wells that reached the crystalline basement in shallow onshore basins ( $<2-3$ $\mathrm{km}$ deep) could yield insights into the evolution of the Meseta, Souss, Ouarzazate, and of the rims of the Tindouf and Taoudeni basins. Moreover, the rifted continental basement below the passive margin could be sampled in structural highs, such as offshore Sidi Ifni (IF-1 well). Potential targets for new LTT data are of little interest without robust dating of sedimentary successions around the sampled grounds.

Sampling the CAMP dykes for LTT analyses would allow a high-resolution study on the exhumation. For this the dykes must contain apatite and or/zircon crystals, have their emplacement temperatures fairly precisely constrained, and be overlain by well-dated sediments. If these conditions are met, at least four well-defined time-temperature constraints can be defined within 200 Myr (emplacement, LTT ages, sediments, and present-day). CAMP dykes are exposed in the study area in the Anti-Atlas, Tindouf basin, Béchar, Ougarta, Reguibat Shield, and Taoudeni basin.

Furthermore, it would be interesting to redesign the time-temperature modelling from published works in the light of new sediment dating (i.e. geological constraint). This would bring more control points for the interpolation of our exhumation maps and would surely improve the results presented in chapter 4.

\subsubsection{Evidencing eroded $\mathrm{km}$-thick basins}

From an academic and industrial point of view, it would be interesting to investigate further the subsidence episodes documented by LTT. Indeed, it remains uncertain whether or not the heating phases inferred from time-temperature modelling can actually be translated in subsidence related to sedimentation. 
To evidence that these now-eroded basins existed, one may measure the dip of the termination of the sedimentary units around basement outcrops (onlapping or truncated) and to project them onto the older area. One may also sample sediments for diagenesis analysis (e.g. XRD) along a transect that traverses an area of substantial subsidence evidenced by LTT (e.g. during the Early Cretaceous in the central Anti-Atlas). If sediments were indeed deposited over the presently exposed basement, the results should display an increase of diagenesis towards basement, and that cannot be explained with the preserved overburden. Following this line of reasoning, existing metamorphism studies could be used to compare the maximum burial reached by Palaeozoic meta-sediments and the estimated overburden.

\subsubsection{Landscape Evolution Models}

The distribution of eroded sediments in the continental rifted margin is controlled by the drainage systems, which connect the exhuming and the subsiding domains. Most of these systems are not preserved, resulting in a lack of data for their size, sediment fluxes, and entry-point position.

Important and interesting progresses have been made in numerical models of geomorphology. Paleo-altimetry and sediment routing may be approached with process-based numerical models generally called Landscape Evolution Model (LEM).

A next step for the understanding and quantification of the Moroccan Phanerozoic source-to-sink systems is to apply these models to cases along the Atlantic rifted margin. Moreover, tectonic, climatic and eustatic scenarios may also be tested.

\subsubsection{Remote sensing in the Tindouf basin: Short Wavelength IR (SWIR)}

Large regions of Africa have been left untouched by any kind of LTT studies, either because they are fairly remote or for the absence of apatite and or zircon crystals in the exposed rocks. The western termination of the Tindouf basin shows a great exposure of Devonian and Carboniferous meta-sediments, with little to no vegetation, and is far from dense road networks.

However, the kinematic evolution of this basin is key for source-to-sink systems as it connects two major source areas, the Anti-Atlas and the Reguibat Shield, and stretches out over 100,000 km². If this basin was a source area during one or several periods of its Phanerozoic history, then substantial volumes of eroded material must have been exported.

One should begin with a feasibility study of using SWIR as a proxy for remote investigation of the thermal maturity of largely exposed sedimentary layers. The SWIR may be used to estimate the Illite Spectral Maturity (e.g. Doublier et al., 2010), somewhat similar to Illite Crystallinity, which is a proxy for thermal maturity. The initial plan could be to calibrate the SWIR scenes from ASTER products with SWIR measurements, Illite Crystallinity (with XRD), and Vitrinite Reflectance from hand 
samples collected in the north Tarfaya and western Tindouf basins. It is worth noting that the temperature range for the application of this paleo-thermometer is relevant to this survey.

\subsubsection{Salt mobilisation}

The results from the investigation of the timing and evolution of salt-cored anticline in the Essaouira-Agadir basin (Hafid et al., 2011; Kluge, 2016) are comparable to that of studies conducted in the central High Atlas (e.g. Saura et al., 2014; Moragas et al., 2017) and offshore Essaouira (Pichel et al., 2017). The first mobilization of Triassic salt in these basins occurred in the Early-Middle Jurassic (fig. 7.1).

The proposed mechanisms for the halokinesis are usually a combination of differential loading, modification of the heat gradient, heterogeneity of the salt-substratum (e.g. basement faults), compressional or extensional forces, and slope instability (e.g. Alsop et al., 1996; Fort et al., 2004). No consensus has yet been proposed for the triggering mechanism(s) in the Moroccan salt basins. One puzzling trait of this system is the lack of documented diapirism in the Souss and Ouarzazate basins.

However, the Early to Middle Jurassic epochs are characterized by an important exhumation of the Anti-Atlas (this Thesis). It is therefore possible that this exhumation was associated to surface uplift, inducing an steepening of the slopes of the salt basin substratum, north of the belt. This new relief would eventually lead to lateral fluxes of salt, onset of gravitational forces deforming Jurassic sediments (fig. 7.1), and when associated with normal rift faults creating buttresses along which the salt bodies would start their ascension. Moreover, the production of material from the Anti-Atlas may have triggered differential loading of detritic sediments in the High Atlas basin, induced by the distribution of the entry-points. This hypothesis remains very speculative, but could be tested with tailored finite element models. 


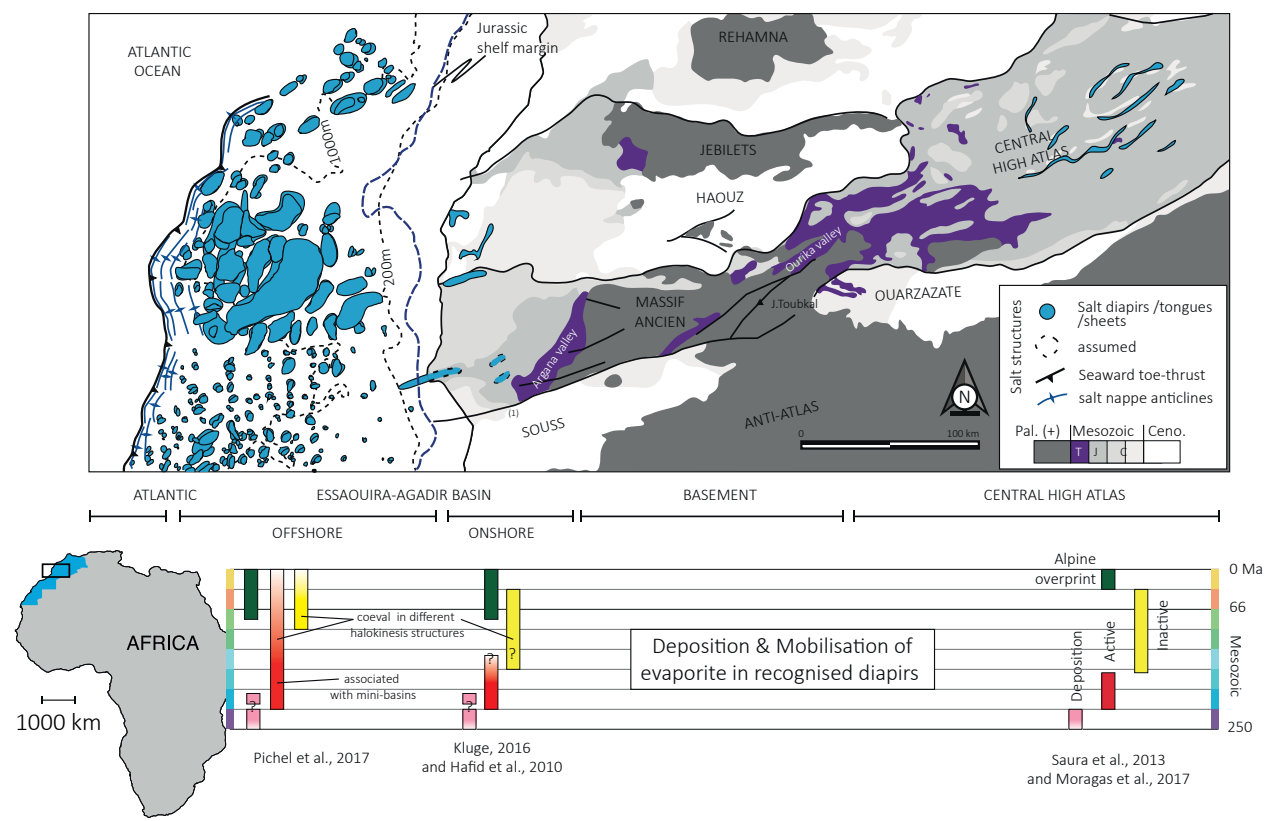

Figure 7.1. Comparison of salt activities in the salt basins of Morocco. Pal. (+): Palaeozoic and older, T: Triassic, J: Jurassic, C: Cretaceous, and Ceno: Cenozoic. The Jurassic shelf margin is after Hafid et al., 2010. Salt bodies distribution in the offshore domain is after Pichel (in preparation).

\subsubsection{Hydrocarbon exploration}

Regarding hydrocarbon exploration in the Moroccan offshore, a future application of our results is to use the 'source-to-sink' maps presented in chapter 5 as gross depositional environment maps in the exploration of the shelf, slope, and deep basin. Furthermore, a next step forward could be to accurately predict the reservoir distribution in the Moroccan Atlantic offshore and coastal basins with stratigraphic modelling (e.g. Delft3D; Dionisos).

The required inputs have been partially gathered in this Thesis: hinterland exhumation history, eroded material fluxes, nature of the eroded material, and possible entry points. Other inputs, all within our reach (literature and wells reports), are the subsidence history of the preserved basins, the climatic evolution, the sea-level curve, and the base surface for the sedimentary system to build on.

Last, there are established relationships between sediment provenance and reservoir quality (e.g. Rossi et al., 2002). Provenance studies have been and are conducted in Morocco (see chapter 5; Roquette, in progress). Their results, combined with our source-to-sink maps, will help to further integrate this notion in the Moroccan offshore and onshore plays. 
Acknowledgements: Giovanni Bertotti and Joep Storms are thanked for the geological discussions. Christian Kluge, Aude Duval-Arnould, and Leonardo Muniz-Pichel are thanked for their design and content inputs of figure 7.1. Frank Van Ruitenbeek (Twente University) and Cedric Thieulot (Utrecht University) are thanked for their collaboration regarding sections 7.2 .4 and 7.2 .5 , respectively. 


\section{References}

Abou Ali, N., Chellaie, E.H. and Nahim, M., 2004. Anatomie d'une marge passive hybride. Marge Ifni/Tan-Tan (sud du Maroc) au Mésozoïque: Apports des données géophysiques: Estudios Geológicos, 60, p. 111-121.

Adaci, M., Tabuce, R., Mebrouk, F., Bensalah, M., Fabre, P.-H., Hautier, L., Jaeger, J.-J., Lazzari, V., Mahboubi, M., Marivaux, L. and Otero, O., 2007. Nouveaux sites à vertébrés paléogènes dans la région des Gour Lazib (Sahara Nord-occidental, Algérie): Comptes Rendus Palevol, 6, p. 535-544.

Aït Boughrous, A., Boulanouar, M., Yacoubi, M. and Coineau, N., 2007. The first Microcharon (Crustacea Isopoda, Microparasellidae) from the Moroccan North Saharan Platform. Origin and palaeobiogeography: Contribution to Zoology, 76, p. 19-32.

Akkouche, M., 2007. Application de la datation par traces de fission à l'analyse de la thermicité de bassins à potentialités pétrolières. Exemple de la cuvette de Sbaâ et du bassin de l'Ahnet-Nord (plate-forme saharienne occidentale, Algerie): Université de Bordeaux, Ph.D. Thesis, 297 p.

Ali, S., Stattegger, K., Garbe-Schönberg, D., Frank, M., Kraft, S. and Kuhnt, W., 2014. The provenance of Cretaceous to Quaternary sediments in the Tarfaya basin, SW Morocco: Evidence from trace element geochemistry and radiogenic $\mathrm{Nd}-\mathrm{Sr}$ isotopes: Journal of African Earth Sciences, 90, p. 64-76.

Allain, R., Aquesbi, N., Dejax, J., Meyer, C., Monbaron, M., Montenat, C., Richir, P., Rochdy, M., Russell, D. and Taquet, P., 2004. A basal sauropod dinosaur from the Early Jurassic of Morocco: Comptes Rendus Palevol, 3, p. 199-208.

Allen, P.A., 2008. From landscapes into geological history: Nature, 451, p. 274.

Allen, P.A. and Allen, J.R., 2013. Basin Analysis: Principles and application to petroleum play assessment, Wiley-Blackwell, $632 \mathrm{p}$.

Aloui, T., Dasgupta, P. and Chaabani, F., 2012. Facies pattern of the Sidi Aïch Formation: Reconstruction of Barremian paleogeography of Central North Africa: Journal of African Earth Sciences, 71-72, p. 18-42.
Alsop, G.I., Blundell, D.J. and Davison, I., 1996. Salt tectonics: Geological Society Special Publication London, $310 \mathrm{p}$.

Ambroggi, R. and Lapparent, A., 1954. Découverte d'empreintes de pas de Reptiles dans le Maestrichtien d'Agadir (Maroc): Compte Rendu sommaire des séances de la Société géologique de France, p. 51-52.

Amidon, W.H., Roden-Tice, M., Anderson, A.J., McKeon, R.E. and Shuster, D.L., 2016. Late Cretaceous unroofing of the White Mountains, New Hampshire, USA: An episode of passive margin rejuvenation?: Geology, 44, p. 415-418.

Andreu, B. and Tronchetti, G., 1994. Ostracodes et foraminifères du Crétacé supérieur du synclinal d'El Koubbat, Moyen Atlas, Maroc: Biostratigraphie, Paléoenvironements, Paléobiogéopgraphie, systématique des ostracodes: Congrès français de stratigraphie, 1, Toulouse.

Aquit, M., Kuhnt, W., Holbourn, A., Hassane Chellai, El, Stattegger, K., Kluth, O. and Jabour, H., 2013. Late Cretaceous paleoenvironmental evolution of the Tarfaya Atlantic coastal Basin, SW Morocco: Cretaceous Research, 45, p. 288-305.

Arab, M., Bracène, R., Roure, F., Zazoun, R.S., Mahdjoub, Y. and Badji, R., 2015. Source rocks and related petroleum systems of the Chelif Basin, (western Tellian domain, north Algeria): Marine and Petroleum Geology, 64, p. 363-385.

Arabi, El, E.H., Ferrandini, J. and Essamoud, R., 2003. Triassic stratigraphy and structural evolution of a rift basin: The Eç Çour basin, High atlas of Marrakech, Morocco: Journal of African Earth Sciences, 36, p. 2939.

Arantegui, A., 2018. Characterisation of Mesozoic Depositional Systems along the Atlantic Passive Margin of Morocco. North Aaiun-Tarfaya Basin: University of Manchester, Ph.D. Thesis, 169 p.

Arantegui, A., Luber, T., Charton, R., Simmons, M., Bertotti, G. and Redfern, J., 2016. Temporal and spatial evolution of Mesozoic drainage systems feeding the deepwater Atlantic passive margin of Morocco: Tarfaya Basin. International Association of Sedimentology meeting, 32, Marrakech. 
Arboleya, M.L., Teixell, A., Charroud, M. and Julivert, M., 2004. A structural transect through the High and Middle Atlas of Morocco: Journal of African Earth Sciences, 39, p. 319-327.

Avigad, D., Gerdes, A., Morag, N. and Bechstädt, T., 2012. Coupled $\mathrm{U}-\mathrm{Pb}-\mathrm{Hf}$ of detrital zircons of Cambrian sandstones from Morocco and Sardinia: Implications for provenance and Precambrian crustal evolution of North Africa: Gondwana Research, 21, p. 690-703.

Azdimousa, A., Bourgois, J., Poupeau, G. and Montigny, R., 1998. Thermal history of the Ketama massif (Morocco): Constraints from $\mathrm{K} / \mathrm{Ar}$ analyses and fission track thermochronology: Comptes Rendus de I'Académie des Sciences, 326, p. 847-853.

Azdimousa, A., Bourgois, J., Poupeau, G., Vázquez, M., Asebriy, L. and Labrin, E., 2013. Fission track thermochronology of the Beni Bousera peridotite massif (Internal Rif, Morocco) and the exhumation of ultramafic rocks in the Gibraltar Arc: Arabian Journal of Geosciences, 7, p. 1993-2005.

Babault, J., Teixell, A., Arboleya, M.-L. and Charroud, M., 2008. A Late Cenozoic age for long-wavelength surface uplift of the Atlas Mountains of Morocco: Terra Nova, 20, p. 102-107.

Balestrieri, M.L., Moratti, G., Bigazzi, G. and Algouti, A., 2009. Neogene exhumation of the Marrakech High Atlas (Morocco) recorded by apatite fission-track analysis: Terra Nova, 21, p. 75-82.

Barbarand, J., 2003. Compositional and structural control of fission-track annealing in apatite: Chemical Geology, 198, p. 107-137.

Barbero, L., Jabaloy, A., Gómez-Ortiz, D., Pérez-Peña, J.V., Rodríguez-Peces, M.J., Tejero, R., Estupiñán, J., Azdimousa, A., Vázquez, M. and Asebriy, L., 2011. Evidence for surface uplift of the Atlas Mountains and the surrounding peripheral plateaux: Combining apatite fission-track results and geomorphic indicators in the Western Moroccan Meseta (coastal Variscan Paleozoic basement): Tectonophysics, 502, p. 90-104.

Barbero, L., Teixell, A., Arboleya, M.-L., Río, P.D., Reiners, P.W. and Bougadir, B., 2007. Jurassic-topresent thermal history of the central High Atlas (Morocco) assessed by low-temperature thermochronology: Terra Nova, 19, p. 58-64.

Barnes, J.B. and Heins, W.A., 2009. Plio-Quaternary sediment budget between thrust belt erosion and foreland deposition in the central Andes, southern Bolivia: Basin Research, 21, p. 91-109.

Barnett-Moore, N., Hassan, R., Müller, R.D., Williams, S.E. and Flament, N., 2017. Dynamic topography and eustasy controlled the paleogeographic evolution of northern Africa since the mid-Cretaceous: Tectonics, 36, p. 929-944.

Baudon, C., Fabuel-Perez, I. and Redfern, J., 2009. Structural style and evolution of a Late Triassic rift basin in the Central High Atlas, Morocco: Controls on sediment deposition: Geological Journal, 44, p. 677691.

Beauvais, L., 1986. Monographie des madréporaires du Jurassique inférieur du Maroc: Palaeontographica, 194, p. 1-68.

Belka, Z., 1991. Conodont Color Alteration Patterns in Devonian Rocks of the Eastern Anti-Atlas, Morocco: Journal of African Earth Sciences, 12, p. 417-428.

Benvenuti, M., Moratti, G. and Algouti, A., 2017. Stratigraphic and structural revision of the Upper Mesozoic succession of the Dadès valley, eastern Ouarzazate Basin (Morocco): Journal of African Earth Sciences, 135, p. 1-45.

Benyoucef, M., 2012. Le Bassin Crétacé Du Guir (SudOuest Algerien): Caractérisations LithoBiostratigraphiques, Sedimentologiques \& Paléogéographiques: Université de Tlemcen, Ph.D. Thesis, $220 \mathrm{p}$.

Benyoucef, M., Malti, F.-Z., Adaci, M., Fellah, A.H., Abbache, A., Cherif, A., Sidhoum, R. and Bensalah, M., 2015. Évolution lithostratigraphique, paléoenvironnementale et paléogéographique du flysch de Ben-Zireg (Viséen inférieur, Algérie): Geodiversitas, 37, p. 5-29.

Benzaggagh, M., 2016. Tholeitic basalts and ophiolitic complexes of the Mesorif Zone (External Rif, Morocco) at the Jurassic-Cretaceous boundary and the importance of the Ouerrha Accident in the palaeogeographic and geodynamic evolution of the Rif Mountains: Boletín geológico y minero, 127, p. 389406.

Benzaggagh, M., Latil, J.-L., Oumhamed, M. and Ferré, B., 2017. Stratigraphic succession (Albian to lower? Cenomanian) and upper Albian ammonites and biozones from the Talerhza Basin (South Riffian Ridges, northern Morocco): Cretaceous Research, 73, p. 7190.

Bertotti, G, 2001. Subsidence, deformation, thermal and mechanical evolution of the Mesozoic South Alpine rifted margin: an analogue for Atlantic-type margins: Geological Society, London, Special Publications, 187, p. 125-141.

Bertotti, G. and Gouiza, M., 2012. Post-rift vertical movements and horizontal deformations in the eastern margin of the Central Atlantic: Middle Jurassic to Early Cretaceous evolution of Morocco: 
International Journal of Earth Sciences, 101, p. 21512165.

Best, M.W. and Boekschoten, G.J., 1981. On the coral fauna in the Miocene reef at Baixo, Porto Santo (Eastern Atlantic): Netherlands Journal of Zoology, 32, p. 412-418

Beuf, S., Biju-Duval, B., de Charpal, O., Rognon, P., Gabriel, O. and Bennacef, A., 1971. Les Grès du paléozoïque inférieur au Sahara: Sédimentation et discontinuités. Evolution structurale d'un craton: Publications de l'Institut Français du Pétrole, 480 p.

Biari, Y., Klingelhoefer, F., Sahabi, M., Funck, T., Benabdellouahed, M., Schnabel, M., Reichert, C., Gutscher, M.A., Bronner, A. and Austin, J.A., 2017. Opening of the central Atlantic Ocean: Implications for geometric rifting and asymmetric initial seafloor spreading after continental breakup: Tectonics, 369, p. 75-22.

Bigot-Cormier, F., 2002. La surrection du massif cristallin externe de l'Argentera (France-Italie) et ses relations avec la déformation Pliocene de la marge Nord-Ligure: Arguments thermochronologiques (traces de fission), geémorphologiques et interpretations de sismique marine: Université Nice Sophia Antipolis, Ph.D. Thesis, 354 p.

Binnie, S.A., Phillips, W.M., Summerfield, M.A., Fifield, L.K. and Spotila, J.A., 2008. Patterns of denudation through time in the San Bernardino Mountains, California: Implications for early-stage orogenesis: Earth and Planetary Science Letters, 276, p. 1-11.

Blain, H.-A., Sesé, C., Rubio-Jara, S., Panera, J., Uribelarrea, D. and Pérez-González, A., 2013. Reconstitution paléoenvironnementale et paléoclimatique du Pléistocène supérieur ancien (MIS 5a) dans le Centre de l'Espagne: Les petits vertébrés (Amphibia, Reptilia \& Mammalia) des gisements de HAT et PRERESA (Sud-est de Madrid). Revue de I'Association française pour l'étude du Quaternaire, 24, p. 191-205.

Bonhomme, M. and Hassenforder, B., 1985. Le métamorphisme hercynien dans les formations tardiet post-panafricaines de I'Anti-Atlas occidental (Maroc). Données isotopiques $\mathrm{Rb} / \mathrm{Sr}$ et $\mathrm{K} / \mathrm{Ar}$ des fractions fines: Bulletin de la Société Géologique, 38, p. 175-183.

Bouatmani, R., Chakor, A. and Medina, F., 2007. Subsidence, évolution thermique et maturation des hydrocarbures dans le bassin d'Essaouira (Maroc): Apport de la modélisation: Bulletin de I'Institut Scientifique de Rabat, 29, p. 15-36.

Bourillot, R., Neige, P., Pierre, A. and Durlet, C., 2008. Early-Middle Jurassic Lytoceratid Ammonites with constrictions from Morocco: Palaeobiogeographical and evolutionary implications: Palaeontology, 51, p. 597-609.

Brahim, L.A., Chotin, P., Hinaj, S., Abdelouafi, A., Adraoui, El, A., Nakcha, C., Dhont, D., Charroud, M., Alaoui, F.S., Amrhar, M., Bouaza, A., Tabyaoui, H. and Chaouni, A., 2002. Paleostress evolution in the Moroccan African margin from Triassic to Present: Tectonophysics, 357, p. 187-205.

Brandon, M.T., Roden-Tice, M.K. and Garver, J.I., 1998. Late Cenozoic exhumation of the Cascadia accretionary wedge in the Olympic Mountains, northwest Washington State: Geological Society of America Bulletin, 110, p. 985-1009.

Braun, J., 2002. Estimating exhumation rate and relief evolution by spectral analysis of age-elevation datasets: Terra Nova, 14, p. 210-214.

Braun, J. and Robert, X., 2005. Constraints on the rate of post-orogenic erosional decay from lowtemperature thermochronological data: Application to the Dabie Shan, China: Earth Surface Processes and Landforms, 30, p. 1203-1225.

Bridwell, R.J., 1976. Lithospheric thinning and the late Cenozoic thermal and tectonic regime of the northern Rio Grande rift: New Mexico Geological Society Field Conference, 27, Vermq'o Park.

Broutin, J., Aassoumi, H., Wartiti, El, M., Freytet, P., Kerp, H., Quesada, C. and Toutin-Morin, N., 1998. The Permian basins of Tiddas, Bou Achouch and Khenifra (Central Morocco). Biostratigraphic and palaeophytogeographic implications. Mémoires du Muséum national d'histoire naturelle, 179, p. 257-278.

Broutin, J., Ferrandini, J. and Saber, H., 1989. Implications stratigraphiques et paléogéographiques de la découverte d'une flore permienne euraméricaine dans le Haut-Atlas occidental (Maroc): Comptes rendus de l'Académie des sciences, 308, p. 1509-1514.

Brown, R.H., 1980. Triassic rocks of Argana Valley, southern Morocco, and their regional structural implications: AAPG Bulletin, 64, p. 988-1003.

Brune, S., Heine, C., Pérez-Gussinyé, M. and Sobolev, S.V., 2014. Rift migration explains continental margin asymmetry and crustal hyper-extension: Nature Communications, 5, p. 4014.

Buck, W.R., 1986. Small-Scale Convection Induced by Passive Rifting - the Cause for Uplift of Rift Shoulders: Earth and Planetary Science Letters, 77, p. 362-372.

Buggisch, W. and Flügel, E., 1988. The Precambrian/Cambrian boundary in the Anti-Atlas (Morocco) discussion and new results. In: The Atlas System of Morocco, Springer, p. 81-90. 
Burg, J.-P., Davy, P., Nievergelt, P., Oberli, F., Seward, D., Diao, Z. and Meier, M., 1997. Exhumation during crustal folding in the Namche-Barwa syntaxis: Terra Nova, 9, p. 53-56.

Burkhard, M., Caritg, S., Helg, U., Robert-Charrue, C. and Soulaimani, A., 2006. Tectonics of the Anti-Atlas of Morocco: Comptes Rendus Geoscience, 338, p. 11-24.

Calvín, P., Casas-Sainz, A.M., Villalain, J.J. and Moussaid, B., 2017. Diachronous folding and cleavage in an intraplate setting (Central High Atlas, Morocco) determined through the study of remagnetizations: Journal of Structural Geology, 97, p. 144-160.

Campanile, D.J., 2007. The post-breakup evolution of the western Indian high-elevation passive margin: University of Glasgow, Ph.D. Thesis, 210 p.

Casini, L., Cuccuru, S., Puccini, A., Oggiano, G. and Rossi, P., 2015. Evolution of the Corsica-Sardinia Batholith and late-orogenic shearing of the Variscides: Tectonophysics, 646, p. 65-78.

Cavin, L., Tong, H., Boudad, L., Meister, C., Piuz, A., Tabouelle, J., Aarab, M., Amiot, R., Buffetaut, E., Dyke, G., Hua, S. and Le Loeuff, J., 2010. Vertebrate assemblages from the early Late Cretaceous of southeastern Morocco: An overview: Journal of African Earth Sciences, 57, p. 391-412.

Cederbom, C.E., Sinclair, H.D., Schlunegger, F. and Rahn, M.K., 2004. Climate-induced rebound and exhumation of the European Alps: Geology, 32, p. 709712.

Chalouan, A., Michard, A., Kadiri, El, K., Negro, F., de Lamotte, D.F., Soto, J.I. and Saddiqi, O., 2008. The Rif Belt. In: Continental Evolution: The Geology of Morocco, Springer, p. 203-302.

Charrière, A. and Haddoumi, H., 2016. Les "Couches rouges» continentales jurassico-crétacées des Atlas marocains (Moyen Atlas, Haut Atlas central et oriental): Bilan stratigraphique, paléogéographies successives et cadre géodynamique: Boletín geológico y minero, 127, p. 407-430.

Charton, R., Bertotti, G., Arantegui, A. and Bulot, L., 2018. The Sidi Ifni transect across the rifted margin of Morocco (Central Atlantic): Vertical movements constrained by low-temperature thermochronology: Journal of African Earth Sciences, in press.

Chevalier, J.P. and Choubert, G., 1962. Les madréporaires miocènes du Maroc: Éditions du Service géologique du Maroc, 173, p. 1-74.

Chopin, F., Corsini, M., Schulmann, K., Houicha, El, M., Ghienne, J.-F. and Edel, J.-B., 2014. Tectonic evolution of the Rehamna metamorphic dome (Morocco) in the context of the Alleghanian-Variscan orogeny: Tectonics, 33, p. 1154-1177.

Choubert, G. and Faure-Muret, A., 1971. Anti-Atlas (Maroc). In: Tectonique de I'Afrique, UNESCO, p. 163175.

Choubert, G. and Faure-Muret, A., 1974. Moroccan Rif: Geological Society, London, Special Publications, 4, p. 37-46.

Choubert, G. and Marçais, J., 1952. Géologie du Maroc: Congrès Géologique International, 19, Alger, p. 77194.

Choubert, G., Faure-Muret, A. and Hottinger, L., 1966. Aperçu géologique du bassin côtier de Tarfaya: Editions du Service géologique du Maroc, 285 p.

Clift, P.D., Dewey, J.F., Draut, A.E., Chew, D.M., Mange, M. and Ryan, P.D., 2004. Rapid tectonic exhumation, detachment faulting and orogenic collapse in the Caledonides of western Ireland: Tectonophysics, 384, p. 91-113.

Cogné, N., Gallagher, K. and Cobbold, P.R., 2011. Postrift reactivation of the onshore margin of southeast Brazil: Evidence from apatite (U-Th)/He and fissiontrack data: Earth and Planetary Science Letters, 309, p. 118-130.

Contrucci, I., Klingelhöfer, F., Perrot, J., Bartolome, R., Gutscher, M.A., Sahabi, M., Malod, J. and Rehault, J.-P., 2004. The crustal structure of the NW Moroccan continental margin from wide-angle and reflection seismic data: Geophysical Journal International, 159, p. 117-128.

Cózar, P., García-Frank, A., Somerville, I.D., Vachard, D., Rodríguez, S., Medina-Varea, P. and Said, I., 2014. Lithofacies and biostratigraphical correlation of marine Carboniferous rocks in the Tindouf Basin, NW Africa: Facies, 60, p. 941-962.

Dartevelle, E. and Schwetz, J., 1937. Mollusques récoltés dans le Bas-Congo: Annales de la Société Royale Zoologique de Belgique, 68, p. 49-65.

Davies, J.H.F.L., Marzoli, A., Bertrand, H., Youbi, N., Ernesto, M. and Schaltegger, U., 2017. End-Triassic mass extinction started by intrusive CAMP activity: Nature Communications, 8, 15596.

Davis, D.W. and Green, J.C., 1997. Geochronology of the North American Midcontinent rift in western Lake Superior and implications for its geodynamic evolution: Canadian Journal of Earth Sciences, 34, p. 476-488.

Davison, I., 2005. Central Atlantic margin basins of North West Africa: Geology and hydrocarbon potential (Morocco to Guinea): Journal of African Earth Sciences, 43, p. 254-274. 
Dhondt, A.V., Malchus, N., Boumaza, L. and Jaillard, E., 1999. Cretaceous oysters from North Africa: Origin and distribution: Bulletin de la Société Géologique de France, 170, p. 67-76.

Doglioni, C., Dagostino, N. and Mariotti, G., 1998. Normal faulting vs regional subsidence and sedimentation rate: Marine and Petroleum Geology, 15, p. 737-750.

Domenech, M., 2015. Rift opening and inversion in the Marrakech High Atlas: integrated structural and thermochronologic study: Universitat Autònoma de Barcelona, Ph.D. Thesis, $157 \mathrm{p}$.

Domènech, M., Stockli, D. and Teixell, A., 2017. Detrital zircon $\mathrm{U}-\mathrm{Pb}$ provenance and paleogeography of Triassic rift basins in the Marrakech High Atlas: in review.

Domènech, M., Teixell, A. and Stöckli, D.F., 2016. Magnitude of rift-related burial and orogenic contraction in the Marrakech High Atlas revealed by zircon (U-Th)/He thermochronology and thermal modeling: Tectonics, 35, p. 2609-2635.

Donelick, R.A., 2005. Apatite Fission-Track Analysis: Reviews in Mineralogy and Geochemistry, 58, p. 49-94.

Donelick, R.A. and Miller, D.S., 1991. Enhanced TINT fission track densities in low spontaneous track density apatites using 252 Cf-derived fission fragment tracks: A model and experimental observations: Nuclear Tracks and Radiation Measurements, 18, p. 301-307.

Donelick, R.A., Ketcham, R.A. and Carlson, W.D., 1999. Variability of apatite fission-track annealing kinetics: Crystallographic orientation effects: American Mineralogist, 84, p. 1224-1234.

Doubinger, J., 1956. Contribution à l'étude des flores autuno-stéphaniennes: Société géologique de France, 35, p. 1-180.

Doublier, M.P., Roache, T. and Potel, S., 2010. Shortwavelength infrared spectroscopy: A new petrological tool in low-grade to very low-grade pelites: Geology, 38, p. 1031-1034.

Dumitru, P.D., Plopeanu, M. and Badea, D., 2013. Comparative study regarding the methods of interpolation: Recent Advances in Geodesy and Geomatics engineering, 13, p. 45-52.

Dunkl, I., 2002. TRACKKEY: A Windows program for calculation and graphical presentation of fission track data: Computers \& Geosciences, 28, p. 3-12.

Dunlap, D.B., Wood, L.J. and Moscardelli, L.G., 2013. Seismic geomorphology of early North Atlantic sediment waves, offshore northwest Africa: Interpretation, 1, p. SA75-SA91.
Einsele, G., 1992. Sedimentary basins: Evolution, facies, and sedimentary budget: Springer, $628 \mathrm{p}$.

Ellero, A., Ottria, G., Malusà, M.G. and Ouanaimi, H., 2012. Structural geological analysis of the High Atlas (Morocco): Evidences of a transpressional fold-thrust belt. In: Tectonics-Recent Advances, InTech, p. 229258.

Ellouz, N., Patriat, M., Gaulier, J.-M., Bouatmani, R. and Sabounji, S., 2003. From rifting to Alpine inversion: Mesozoic and Cenozoic subsidence history of some Moroccan basins: Sedimentary Geology, 156, p. 185212.

Elmi, S., Marok, A., Sebane, A. and Alméras, Y., 2009 Importance of the Mellala section (Traras Mountains, northwestern Algeria) for the correlation of the Pliensbachian-Toarcian boundary: Volumina Jurassica, 7, p. 37-45.

England, P. and Molnar, P., 1990. Surface Uplift, Uplift of Rocks, and Exhumation of Rocks: Geology, 18, p. 1173-1177.

English, K.L., Redfern, J., Bertotti, G., English, J.M. and Yahia Cherif, R., 2017. Intraplate uplift: New constraints on the Hoggar dome from the Illizi basin (Algeria): Basin Research, 29, p. 377-393.

Ennih, N. and Liégeois, J.-P., 2001. The Moroccan AntiAtlas: The West African craton passive margin with limited Pan-African activity. Implications for the northern limit of the craton: Precambrian Research, 112, p. 289-302.

Ennouchi, E., 1954. La faune néolithique de Toulkine (Haut Atlas): Comptes rendus des séances mensuelles de la société des sciences naturelles et physiques du Maroc, 20, p. 140-141.

Ernst, W.G., Maruyama, S. and Wallis, S., 1997. Buoyancy-driven, rapid exhumation of ultrahighpressure metamorphosed continental crust: Proceedings of the National Academy of Sciences of the United States of America, 94, p. 9532-9537.

Essafraoui, B., Ferry, S., Groshény, D., Içame, N., Aouli, El, H., Masrour, M., Bulot, L.G., Géraud, Y. and Aoutem, M., 2015. Sequence stratigraphic architecture of marine to fluvial deposits across a passive margin (Cenomanian, Atlantic margin, Morocco, Agadir transect): Carnet de Géologie, 15, p. 137-172.

Ettachfini, M., Rey, J., Taj-Eddine, K., Tavera, J.M.others, 1998. The Valanginian of the Safi Basin (Atlantic Morocco) and its ammonite fauna. Palaeobiogeographical implications: Comptes Rendus de l'Académie des Sciences, 5, p. 319-325.

Fabre, J., 1988. Les Series Paleozoique d'Afrique: Une approche: Journal of African Earth Sciences, 7, p. 1-40. 
Fabre, J., 2005. Géologie du Sahara occidental et central: Tervuren African Geoscience Collection, 108, $572 \mathrm{p}$.

Faik, F., Belfoul, M.A., Bouabdelli, M. and Hassenforder, B., 2001. Les structures de la couverture Néoprotérozoïque terminal et Paléozoïque de la région de Tata, Anti-Atlas centre-occidental, Maroc: Déformation polyphasée, ou interactions socle/couverture pendant l'orogenèse hercynienne?: Journal of African Earth Sciences, 32, p. 765-776.

Farley, K.A., 2000. Helium diffusion from apatite: General behavior as illustrated by Durango fluorapatite: Solid Earth, 105, p. 2903-2914.

Farley, K.A., 2002. (U-Th)/He Dating: Techniques, Calibrations, and Applications: Reviews in Mineralogy and Geochemistry, 47, p. 819-844.

Fernández-Blanco, D. and Gouiza, M., 2015. NW Africa post-rift tectonics: Fieldwork constraints from an 'unfitting' anticline in west Morocco: EGU General Assembly, Vienna.

Fetah, M., Bensaid, M. and Dahmani, M., 1990. Carte Géologique du Maroc: Zawyat Ahancal (1:100,000): Ministere de l'Energie et des Mines.

Fleischer, R.L. and Hart, H.R., 1972. Fission track dating: Techniques and problems. In: Calibration of Hominoid Evolution, Scottish Academic Press, p. 135-170.

Flowers, R.M. and Ehlers, T.A., 2018. Rock erodibility and the interpretation of low-temperature thermochronologic data: Earth and Planetary Science Letters, 482, p. 312-323.

Flowers, R.M., Ketcham, R.A., Shuster, D.L. and Farley, K.A., 2009. Apatite $(U-T h) / H e$ thermochronometry using a radiation damage accumulation and annealing model: Geochimica et Cosmochimica Acta, 73, p. 2347-2365.

Fort, X., Brun, J.-P. and Chauvel, F., 2004. Salt tectonics on the Angolan margin, synsedimentary deformation processes: AAPG Bulletin, 88, p. 1523-1544.

Foster, D.A. and Gleadow, A.J., 1992. The morphotectonic evolution of rift-margin mountains in central Kenya: Constraints from apatite fission-track thermochronology: Earth and Planetary Science Letters, 113, p. 157-171.

Foster, D.A. and Gleadow, A.J.W., 1996. Structural framework and denudation history of the flanks of the Kenya and Anza Rifts, East Africa: Tectonics, 15, p. 258271.

Frizon de Lamotte, D., Crespo-Blanc, A., Saint-Bézar, B., Comas, M., Fernandez, M., Zeyen, H., Ayarza, P., Robert-Charrue, C., Chalouan, A. and Zizi, M., 2004.
TRANSMED Transect I: Iberian Meseta-Guadalquivir Basin-Betic Cordillera-Alboran Sea-Rif-Moroccan Meseta-High Atlas-Sahara Platform. In: The TRANSMED Atlas: The Mediterranean Region from Crust to Mantle, Springer, p. 141.

Frizon de Lamotte, D., Fourdan, B., Leleu, S., Leparmentier, F. and de Clarens, P., 2015. Style of rifting and the stages of Pangea breakup: Tectonics, 34, p. 1009-1029.

Frizon de Lamotte, D., Leturmy, P., Missenard, Y., Khomsi, S., Ruiz, G., Saddiqi, O., Guillocheau, F. and Michard, A., 2009. Mesozoic and Cenozoic vertical movements in the Atlas system (Algeria, Morocco, Tunisia): An overview: Tectonophysics, 475, p. 9-28.

Frizon de Lamotte, D., Saint-Bézar, B., Bracène, R. and Mercier, E., 2000. The two main steps of the Atlas building and geodynamics of the western Mediterranean: Tectonics, 19, p. 740-761.

Frizon de Lamotte, D., Tavakoli-Shirazi, S., Leturmy, P., Averbuch, O., Mouchot, N., Raulin, C., Leparmentier, F., Blanpied, C. and Ringenbach, J.-C., 2013. Evidence for Late Devonian vertical movements and extensional deformation in northern Africa and Arabia: Integration in the geodynamics of the Devonian world: Tectonics, 32, p. 107-122.

Gaffney, E.S., Tong, H. and Meylan, P.A., 2006. Evolution of the side-necked turtles: The families Bothremydidae, Euraxemydidae, and Araripemydidae: Bulletin of the American Museum of Natural History, 300, 698 p.

Gallagher, K., 2012. Transdimensional inverse thermal history modeling for quantitative thermochronology: Solid Earth, 117, p. 2156-2202.

Gallagher, K. and Brown, R., 1997. The onshore record of passive margin evolution: Journal of the Geological Society, 154, p. 451-457.

Gallagher, K., Brown, R. and Johnson, C., 1998. Fission track analysis and its applications to geological problems: Annual Review of Earth and Planetary Sciences, 26, p. 519-572.

Garzanti, E., Vermeesch, P., Padoan, M., Resentini, A., Vezzoli, G. and Andò, S., 2014. Provenance of passivemargin sand (Southern Africa): The Journal of Geology, 122, p. 17-42.

Gasquet, D., Ennih, N., Liégeois, J.P., Soulaimani, A. and Michard, A., 2008. The Pan-African Belt. In: Continental Evolution: The Geology of Morocco Springer, p. 33-64.

Gemignani, L., Sun, X., Braun, J., Gerve, T.D. and Wijbrans, J.R., 2017. A new detrital mica 40Ar/39Ar dating approach for provenance and exhumation of the Eastern Alps: Tectonics, 36, p. 1521-1537. 
Ghorbal, B., 2009. Mesozoic to Quaternary thermotectonic evolution of Morocco (NW Africa): Vrije Universiteit Amsterdam, Ph.D. Thesis, 226 p.

Ghorbal, B., Bertotti, G., Foeken, J. and Andriessen, P., 2008. Unexpected Jurassic to Neogene vertical movements in 'stable' parts of NW Africa revealed by low temperature geochronology: Terra Nova, 20, p. 355-363.

Gingerich, P.D. and Zouhri, S., 2015. New fauna of archaeocete whales (Mammalia, Cetacea) from the Bartonian middle Eocene of southern Morocco: Journal of African Earth Sciences, 111, p. 273-286.

Gleadow, A.J.W., Duddy, I.R., Green, P.F. and Lovering, J.F., 1986. Confined fission track lengths in apatite: A diagnostic tool for thermal history analysis: Contributions to Mineralogy and Petrology, 94, p. 405415.

Gouiza, M., 2011. Mesozoic source-to-sink systems in NW Africa: Geology of vertical movements during the birth and growth of the Moroccan rifted margin: Vrije Universiteit Amsterdam, Ph.D. Thesis, 170 p.

Gouiza, M., Bertotti, G., Hafid, M. and Cloetingh, S., 2010. Kinematic and thermal evolution of the Moroccan rifted continental margin: Doukkala-High Atlas transect: Tectonics, 29, TC5008.

Gouiza, M., Bertotti, G., and Andriessen, P., 2017b. Mesozoic and Cenozoic thermal history of the western Reguibat Shield (West African Craton): Terra Nova, in press.

Gouiza, M., Charton, R., Bertotti, G., Andriessen, P. and Storms, J.E.A., 2017a. Post-Variscan evolution of the Anti-Atlas belt of Morocco constrained from lowtemperature geochronology: International Journal of Earth Sciences, 106, p. 593-616.

Granot, R. and Dyment, J., 2015. The Cretaceous opening of the South Atlantic Ocean: Earth and Planetary Science Letters, 414, p. 156-163.

Green, P.F., Duddy, I.R., Gleadow, A., Tingate, P.R. and Laslett, G.M., 1986. Thermal Annealing of Fission Tracks in Apatite A Qualitative Description: Chemical Geology, 59, p. 237-253.

Green, P.F., Duddy, I.R., Laslett, G.M., Hegarty, K.A., Gleadow, A.W. and Lovering, J.F., 1989. Thermal annealing of fission tracks in apatite. Quantitative modelling techniques and extension to geological timescales: Chemical Geology, 79, p. 155-182.

Green, P.F., Japsen, P., Chalmers, J.A., Bonow, J.M. and Duddy, I.R., 2018. Post-breakup burial and exhumation of passive continental margins: Seven propositions to inform geodynamic models: Gondwana Research, 53, p. 58-81.
Guerit, L., Barrier, L., Jolivet, M., Fu, B. and Métivier, F., 2016. Denudation intensity and control in the Chinese Tian Shan: New constraints from mass balance on catchment-alluvial fan systems: Earth Surface Processes and Landforms, 41, p. 1088-1106.

Guerrak, S., 1989. Time and Space distribution of Palaeozoic oolitic ironstones in the Tindouf Basin, Algerian Sahara: Geological Society, London, Special Publications, 46, p. 1-16.

Guimerà, J., Arboleya, M.L. and Teixell, A., 2011. Structural control on present-day topography of a basement massif: The Central and Eastern Anti-Atlas (Morocco): Geologica Acta, 9, p. 1-23.

Guiraud, R., 1998. Mesozoic rifting and basin inversion along the northern African Tethyan margin: An overview: Geological Society, London, Special Publications, 132, p. 217-229.

Guiraud, R., Bellion, Y., Benkhelil, J. and Moreau, C., 1987. Post-Hercynian Tectonics in Northern and Western Africa: Geological Journal, 22, p. 433-466.

Guiraud, R., Bosworth, W., Thierry, J. and Delplanque, A., 2005. Phanerozoic geological evolution of Northern and Central Africa: An overview: Journal of African Earth Sciences, 43, p. 83-143.

Haddoumi, H., Mebrouk, F., Andreu, R., Tabuce, M., Vianey-Liaud, M., Bensaad, K. and Charrière, A., 2015. Nouvelles données sédimentologiques et paléontologiques (charophytes, ostracodes, coquille d'œuf de dinosaure) sur la Formation du Tigri (Sénonien des Hauts Plateaux méridionaux, Maroc oriental); paléoenvironnements et évolution paléogéographique: Revue de Paléobiologie, 34, p. 85111.

Haddoumi, H., Charrière, A., Andreu, B. and Mojon, P.O., 2008. Les dépôts continentaux du Jurassique moyen au Crétacé inférieur dans le Haut Atlas oriental (Maroc): Paléoenvironnements successifs et signification paléogéographique: Carnet de Géologie, 06, p. 1-29.

Hadi, El, H., Simancas, J.F., Martínez-Poyatos, D., Azor, A., TAHIRI, A., Montero, P., Fanning, C.M., Bea, F. and González-Lodeiro, F., 2010. Structural and geochronological constraints on the evolution of the Bou Azzer Neoproterozoic ophiolite (Anti-Atlas, Morocco): Precambrian Research, 182, p. 1-14.

Hafid, M., Bally, A.W., Salem, A.A. and Toto, E., 2010. Salt tectonics and structural styles of the western High Atlas and the intersecting Essaouira-Cap Tafelney segments of the Moroccan Atlantic margin: In: Quaternary carbonate and evaporite sedimentary facies and their ancient analogues: A tribute to Douglas 
James Shearman: International Association of Sedimentology Special publication, p. 405-419.

Hafid, M., Tari, G., Bouhadioui, I., Moussaid, El, E., Echarfaoui, H., Aït Salem, H., Nahim, M. and Dakki, M., 2008. Atlantic Basins. In: Continental Evolution: The Geology of Morocco: Springer, p. 303-329.

Hafid, M., Zizi, M., Bally, A.W. and Ait Salem, A., 2006. Structural styles of the western onshore and offshore termination of the High Atlas, Morocco: Comptes Rendus Geoscience, 338, p. 50-64.

Elhaimer, F.Z., 2014. Mouvements verticaux postVarisques des domaines Mesetien et Atlasique: Thermochronology basse température sur apatite et zircon: Université Hassan II, Ph.D. Thesis, 124 p.

Haq, B.U., Hardenbol, J. and Vail, P.R., 1987. Chronology of fluctuating sea levels since the Triassic: Science, 235, p. 1156-1167.

Hefferan, K., Soulaimani, A., Samson, S.D., Admou, H., Inglis, J., Saquaque, A., Latifa, C. and Heywood, N., 2014. A reconsideration of Pan African orogenic cycle in the Anti-Atlas Mountains, Morocco: Journal of African Earth Sciences, 98, p. 34-46.

Hefferan, K.P., Admou, H., Karson, J.A. and Saquaque, A., 2000. Anti-Atlas (Morocco) role in Neoproterozoic Western Gondwana reconstruction: Precambrian Research, 103, p. 89-96.

Helg, U., Burkhard, M., Caritg, S. and Robert-Charrue, C., 2004. Folding and inversion tectonics in the AntiAtlas of Morocco: Tectonics, 23, p. 1-17.

Helland-Hansen, W., Sømme, T.O., Martinsen, O.J., Lunt, I. and Thurmond, J., 2016. Deciphering Earth's Natural Hourglasses: Perspectives On Source-To-Sink Analysis: Journal of Sedimentary Research, 86, p. 10081033.

Helm, C., 2009. Quantification des flux sédimentaires anciens à l'échelle d'un continent: Le cas de l'Afrique au Méso-Cénozoïque: Université Rennes, Ph.D. Thesis, $364 \mathrm{p}$.

Hill, R.V., Mccartney, J.A., Roberts, E., Bouaré, M., Sissoko, F. and O'leary, M.A., 2008. Dyrosaurid (Crocodyliformes: Mesoeucrocodylia) Fossils from the Upper Cretaceous and Paleogene of Mali: Implications for Phylogeny and Survivorship across the $\mathrm{K} / \mathrm{T}$ Boundary: American Museum Novitates, 3631, p. 1-21.

Hoepffner, C., Soulaimani, A. and Piqué, A., 2005. The Moroccan Hercynides: Journal of African Earth Sciences, 43, p. 144-165.

Hoggard, M.J., White, N. and Al-Attar, D., 2016. Global dynamic topography observations reveal limited influence of large-scale mantle flow: Nature Geoscience, 9, p. 456-463.

Hollard, H., Choubert, G., Bronner, G., Marchand, J. and SOUGY, J., 1985. Carte Géologique du Maroc, (1:1,000,000; 2 sheets): Notes et Mémoires du Service Géologique du Maroc.

Hssaida, T., Chahidi, S., Benzaggagh, M., Riding, J.B. and Oumalch, F., 2014. Associations de kystes de dinoflagellés des séries du Jurassique supérieur (Oxfordien-Tithonien) du Rif externe (Prérif interne et Mésorif, Maroc) et comparaisons régionales: Annales de paleontologie, 100, p. 327-342.

Huismans, R. and Beaumont, C., 2011. Depthdependent extension, two-stage breakup and cratonic underplating at rifted margins: Nature, 473, p. 74.

Hurford, A.J., 1990. Standardization of Fission-Track Dating Calibration - Recommendation by the FissionTrack Working Group of the I.U.G.S. Subcommission on Geochronology: Chemical Geology, 80, p. 171-178.

Hurford, A.J. and Green, P.F., 1983. The zeta age calibration of fission-track dating: Chemical Geology, 41, p. 285-317.

Ibrahim, N., Varricchio, D.J., Sereno, P.C., Wilson, J.A., Dutheil, D.B., Martill, D.M., Baidder, L. and Zouhri, S., 2014. Dinosaur Footprints and Other Ichnofauna from the Cretaceous Kem Kem Beds of Morocco: PLOS ONE, 9, p. e90751-15.

Japsen, P., Bonow, J.M., Green, P.F., Chalmers, J.A. and Lidmar-Bergström, K., 2006. Elevated, passive continental margins: Long-term highs or Neogene uplifts? New evidence from West Greenland: Earth and Planetary Science Letters, 248, p. 330-339.

Japsen, P., Bonow, J.M., Green, P.F., Chalmers, J.A. and Lidmar-Bergström, K., 2009. Formation, uplift and dissection of planation surfaces at passive continental margins - a new approach: Earth Surface Processes and Landforms, 34, p. 683-699.

Japsen, P., Bonow, J.M., Green, P.F., Cobbold, P.R., Chiossi, D., Lilletveit, R., Magnavita, L.P. and Pedreira, A., 2012b. Episodic burial and exhumation in NE Brazil after opening of the South Atlantic: Geological Society of America Bulletin, 124, p. 800-816.

Japsen, P., Chalmers, J.A., Green, P.F. and Bonow, J.M., 2012a. Elevated, passive continental margins: Not rift shoulders, but expressions of episodic, post-rift burial and exhumation: Global and Planetary Change, 90-91, p. 73-86.

Japsen, P., Green, P.F. and Bonow, J.M., 2016b. Burial and exhumation history of the LabradorNewfoundland margin: First observations: Geological Survey of Denmark and Greenland, 35, p. 91-94. 
Japsen, P., Green, P.F., Bonow, J.M., Chalmers, J.A. and Rasmussen, E.S., 2016a. Burial and exhumation history of southernmost Norway estimated from apatite fission-track analysis data constrained by geological observations and stratigraphic landscape analysis: NGF Abstract and Proceedings, 1, p. 26-28.

Javier Álvaro, J., 2013. Late Ediacaran syn-rift/post-rift transition and related fault-driven hydrothermal systems in the Anti-Atlas Mountains, Morocco: Basin Research, 25, p. 348-360.

Jelinek, A.R., Chemale, F., Jr, van der Beek, P.A., Guadagnin, F., Cupertino, J.A. and Viana, A., 2014. Denudation history and landscape evolution of the northern East-Brazilian continental margin from apatite fission-track thermochronology: Journal of South American Earth Sciences, 54, p. 158-181.

Jenny, J. and Jossen, J.A., 1982. Découverte d'empreintes de pas de Dinosauriens dans le Jurassique inférieur (Pliensbachien) du Haut-Atlas central (Maroc): Comptes Rendues hébdomanaires Séances Academie de Sciences, 294, p. 223-226.

Jenny, J., Le Marrec, A. and Monbaron, M., 1981. Les couches rouges du Jurassique moyen du Haut Atlas central (Maroc). Correlations lithostratigraphiques, elements de datations et cadre tectono-sedimentaire: Bulletin de la Societe Geologique de France, S7-XXIII, p. 627-640.

Jossen, J.A. and Filali Moutei, J., 1988. Bassin d'Ouarzazate, synthèse stratigraphique et structurale: Contribution à l'étude des aquifères profonds: Direction de la Recherche et de la planification de l'Eau, Rapport Inédit.

Jouve, S., Larochene, M.O., Bouya, B. and Amaghzaz, M., 2005. A new dyrosaurid crocodyliform from the Palaeocene of Morocco and a phylogenetic analysis of Dyrosauridae: Acta Palaeontologica Polonica, 50, p. 114.

Juez-Larre, J. and Andriessen, P., 2006. Tectonothermal evolution of the northeastern margin of Iberia since the break-up of Pangea to present, revealed by low-temperature fission-track and (UTh)/He thermochronologyA case history of the Catalan Coastal Ranges: Earth and Planetary Science Letters, 243, p. 159-180.

Kammerer, C.F., Nesbitt, S.J. and Shubin, N.H., 2011. The first silesaurid dinosauriform from the Late Triassic of Morocco: Acta Palaeontologica Polonica, 57, p. 277284.

Karlstrom, K.E., Coblentz, D., Dueker, K., Ouimet, W., Kirby, E., Van Wijk, J., Schmandt, B., Kelley, S., Lazear, G., Crossey, L.J., Crow, R., Aslan, A., Darling, A., Aster, R., MacCarthy, J., Hansen, S.M., Stachnik, J., Stöckli,
D.F., Garcia, R.V., Hoffman, M., McKeon, R., Feldman, J., Heizler, M., Donahue, M.S. and the CREST Working Group, 2012. Mantle-driven dynamic uplift of the Rocky Mountains and Colorado Plateau and its surface response: Toward a unified hypothesis: Lithosphere, 4, p. 3-22.

Ketcham, R.A., 2005. Forward and Inverse Modeling of Low-Temperature Thermochronometry Data: Reviews in Mineralogy and Geochemistry, 58, p. 275-314.

Ketcham, R.A., Carter, A., Donelick, R.A., Barbarand, J. and Hurford, A.J., 2007. Improved modeling of fissiontrack annealing in apatite: American Mineralogist, 92, p. 799-810.

Ketcham, R.A., Donelick, R.A. and Donelick, M.B., 2000. AFTSolve: A program for multi-kinetic modeling of apatite fission-track data: Geological Materials Research, 2, p. 1-32.

Ketcham, R.A., Gautheron, C. and Tassan-Got, L., 2011. Accounting for long alpha-particle stopping distances in (U-Th-Sm)/He geochronology: Refinement of the baseline case: Geochimica et Cosmochimica Acta, 75, p. 7779-7791.

Klitgord, K.D. and Hill, G.H., 1986. Continental Margin mapping project, U. S. Atlantic margin: A synthesis of geologic and geophysical data and interpretations: AAPG Bulletin, 70, $608 \mathrm{p}$.

Kluge, C., 2016. A Structural Modeling Approach on Timing \& Evolution of Mesozoic Anticlines in the Western High Atlas, Morocco: TU Delft, M.Sc. Thesis, $42 \mathrm{p}$.

Knight, K.B., Nomade, S., Renne, P.R., Marzoli, A., Bertrand, H. and Youbi, N., 2004. The Central Atlantic Magmatic Province at the Triassic-Jurassic boundary: Paleomagnetic and ${ }^{40} \mathrm{Ar} /{ }^{39} \mathrm{Ar}$ evidence from Morocco for brief, episodic volcanism: Earth and Planetary Science Letters, 228, p. 143-160.

Koeniguer, J.-C., 1967. Etude paléoxylologique du Rio de Oro: Notas y Comunicaciones Insituto Geologico y Minero de España, 96, p. 39-66.

Kuuskraa, V., Stevens, S.H. and Moodhe, K.D., 2013. Technically recoverable shale oil and shale gas resources: An assessment of 137 shale formations in 41 countries outside the United States: US Energy Information Administration, $27 \mathrm{p}$.

Labails, C., Olivet, J.-L., Aslanian, D. and Roest, W.R., 2010. An alternative early opening scenario for the Central Atlantic Ocean: Earth and Planetary Science Letters, 297, p. 355-368.

Lagnaoui, A., Klein, H., Saber, H., Fekkak, A., Belahmira, A. and Schneider, J.W., 2016. New discoveries of archosaur and other tetrapod footprints from the 
Timezgadiouine Formation (Irohalene Member, Upper Triassic) of the Argana Basin, western High Atlas, Morocco - Ichnotaxonomic implications: Palaeogeography, Palaeoclimatology, Palaeoecology, 453, p. 1-9.

Laslett, G.M., Gleadow, A. and Duddy, I.R., 1984. The Relationship Between Fission-Track Length and Track Density in Apatite: Nuclear Tracks and Radiation Measurements, 9, p. 29-38

Laslett, G.M., Kendall, W.S. and Gleadow, A., 1982. Bias in measurement of fission-track length distributions: Nuclear Tracks and Radiation Measurements, 6, p. 7985.

Laville, E. and Piqué, A., 1992. Jurassic Penetrative Deformation and Cenozoic Uplift in the Central High Atlas (Morocco): A Tectonic Model. Structural and Orogenic Inversions: Geologische Rundschau, 81, p. 157-170.

Le Roy, P. and Piqué, A., 2001. Triassic-Liassic Western Moroccan synrift basins in relation to the Central Atlantic opening: Marine Geology, 172, p. 359-381.

Le Roy, P., Piqué, A., Le Gall, B., Ait Brahim, L., Morabet, A.M. and Demnati, A., 1997. Les bassins cotiers triasico-liasiques du Maroc occidental et la diachronie du rifting intra-continental de l'Atlantique central: Bulletin de la Société Géologique de France, 168, p. 637-648.

Lee, C.W., 1983. Bivalve mounds and reefs of the Central High Atlas, Morocco: Palaeogeography, Palaeoclimatology, Palaeoecology, 43, p. 153-168.

Lee, E.Y. and Wagreich, M., 2017. Polyphase tectonic subsidence evolution of the Vienna Basin inferred from quantitative subsidence analysis of the northern and central parts: International Journal of Earth Sciences, 106, p. 687-705.

Leeder, M.R., 2006. Sedimentology and sedimentary basins: From turbulence to tectonics: John Wiley \& Sons, $608 \mathrm{p}$.

Leleu, S., Hartley, A.J., van Oosterhout, C., Kennan, L., Ruckwied, K. and Gerdes, K., 2016. Structural, stratigraphic and sedimentological characterisation of a wide rift system: The Triassic rift system of the Central Atlantic Domain: Earth Science Reviews, 158, p. 89-124.

Leprêtre, R., 2015. Evolution Phanerozoïque du Craton Ouest Africain et de ses bordures Nord et Ouest: Université Paris 11, Ph.D. Thesis, 423 p.

Leprêtre, R., Barbarand, J., Missenard, Y., Gautheron, C., Pinna-Jamme, R. and Saddiqi, O., 2017. Mesozoic evolution of NW Africa: implications for the Central
Atlantic Ocean dynamics: Journal of the Geological Society, 174, p. 817-835.

Leprêtre, R., Barbarand, J., Missenard, Y., Leparmentier, F. and Frizon de Lamotte, D., 2013. Vertical movements along the northern border of the West African Craton: The Reguibat Shield and adjacent basins: Geological Magazine, 151, p. 1-14.

Leprêtre, R., Missenard, Y., Barbarand, J., Gautheron, C., Saddiqi, O. and Pinna-Jamme, R., 2015. Post-rift history of the eastern Central Atlantic passive margin: insights from the Saharan region of South Morocco: Solid Earth, 120, p. 4645-4666.

Leroy, M., Gueydan, F. and Dauteuil, O., 2008. Uplift and strength evolution of passive margins inferred from 2-D conductive modelling: Geophysical Journal International, 172, p. 464-476.

Louis, B., 2015. Late Cenozoic Upper-crustal Cooling History of the Shuswap Metamorphic Complex, Southern Canadian Cordillera, British Columbia: New Insights from Low-temperature MultiThermochronometry and Inverse Thermal Model- ing: Dalhousie University, M.Sc. Thesis, 226 p.

Luber, T., 2017. Integrated Analysis of Lower Cretaceous Stratigraphy and depositional systems: The Essaouira-Agadir basin of Morocco: University of Manchester, Ph.D. Thesis, 257 p.

Lundin, E.R. and Doré, A.G., 2017. The Gulf of Mexico and Canada Basin: Genetic Siblings on Either Side of North America: GSA Today, 27, p. 4-11.

Luth, S.W. and Willingshofer, E., 2008. Mapping of the post-collisional cooling history of the Eastern Alps: Swiss Journal of Geosciences, 101, p. 207-223.

Lüning, S., Kolonic, S., Belhadj, E.M., Belhadj, Z., Cota, L., Barić, G. and Wagner, T., 2004. Integrated depositional model for the Cenomanian-Turonian organic-rich strata in North Africa: Earth Science Reviews, 64, p. 51-117.

Mahammed, F., Läng, E., Mami, L., Mekahli, L., Benhamou, M., Bouterfa, B., Kacemi, A., Chérief, S.-A., Chaouati, H. and Taquet, P., 2005. The 'giant of Ksour', a Middle Jurassic sauropod dinosaur from Algeria: Comptes Rendus Palevol, 4, p. 707-714.

Malusà, M.G., Polino, R., Feroni, A.C., Ellero, A., Ottria, G., Baidder, L. and Musumeci, G., 2007. Post-Variscan tectonics in eastern Anti-Atlas (Morocco): Terra Nova, 19 , p. 481-489.

Mansour, E.M., 1991. Thermochronologie par la méthode des traces de fission dans l'apatite. Application aux massifs de l'Argentera-Mercantour (Alpes occidentales) et des Jebilet (Meseta marocaine): Université de Grenoble, Ph.D. Thesis, 197 p. 
Marivaux, L., Adnet, S., Benammi, M., Tabuce, R. and Benammi, M., 2017. Anomaluroid rodents from the earliest Oligocene of Dakhla, Morocco, reveal the longlived and morphologically conservative pattern of the Anomaluridae and Nonanomaluridae during the Tertiary in Africa: Journal of Systematic Palaeontology, 15, p. 539-569.

Martinis, B. and Visintin, V., 1966. Données géologiques sur le bassin sédimentaire côtier de Tarfaya (Maroc méridional). In: Bassins sédimentaires du Littoral Africain, Association des Services Géologiques Africain, p. 13-26.

Martinsen, O.J., Sømme, T.O., Thurmond, J.B., HellandHansen, W. and Lunt, I., 2010. Source-to-sink systems on passive margins: Theory and practice with an example from the Norwegian continental margin: Geological Society of London, 7, p. 913-920.

Martín-Monge, A., Baudino, R., Gairifo-Ferreira, L.M., Tocco, R., Badalì, M., Ochoa, M., Haryono, S., Soriano, S., Hafiz, El, N., Hernán-Gómez, J., Chacon, B., Brisson, I., Grammatico, G., Varadé, R. and Abdallah, H., 2017. An unusual Proterozoic petroleum play in Western Africa: The Atar Group carbonates (Taoudeni Basin, Mauritania): Geological Society, London, Special Publications, 438, p. 119-157.

Marzoli, A., Davies, J.H.F.L., Youbi, N., Merle, R., Corso, J.D., Dunkley, D.J., Fioretti, A.M., Bellieni, G., Medina, F., Wotzlaw, J.-F., McHone, G., Font, E. and Bensalah, M.K., 2017. Proterozoic to Mesozoic evolution of North-West Africa and Peri-Gondwana microplates: Detrital zircon ages from Morocco and Canada: Lithos, 278, p. 1-44.

Marzoli, A., Renne, P.R., Piccirillo, E.M., Ernesto, M., Bellieni, G. and Min, A.D., 1999. Extensive 200-millionyear-old continental flood basalts of the Central Atlantic Magmatic Province: Science, 284, p. 616-618.

Matenco, L., Andriessen, P. and Network, T.S., 2013. Quantifying the mass transfer from mountain ranges to deposition in sedimentary basins: Source to sink studies in the Danube Basin-Black Sea system: Global and Planetary Change, 103, p. 1-18.

Matte, P., 2001. The Variscan collage and orogeny (480-290 Ma) and the tectonic definition of the Armorica microplate: A review: Terra Nova, 13, p. 122128.

Matton, G. and Jébrak, M., 2009. The Cretaceous PeriAtlantic Alkaline Pulse (PAAP): Deep mantle plume origin or shallow lithospheric break-up?: Tectonophysics, 469, p. 1-12.

Mazzoli, S., Ascione, A., Buscher, J.T., Pignalosa, A., Valente, E. and Zattin, M., 2014. Low-angle normal faulting and focused exhumation associated with late
Pliocene change in tectonic style in the southern Apennines (Italy): Tectonics, 33, p. 1802-1818.

Mazzoli, S., Jankowski, L., Szaniawski, R. and Zattin, M., 2010. Low-T thermochronometric evidence for postthrusting: Comptes Rendus Geoscience, 342, p. 162169.

McKenzie, D., 1978. Some remarks on the development of sedimentary basins: Earth and Planetary Science Letters, 40, p. 25-32.

Meister, C., Piuz, A., Cavin, L., Boudad, L., Bacchia, F., M Ettachfini, El and Benyoucef, M., 2016. Late Cretaceous (Cenomanian-Turonian) ammonites from southern Morocco and south western Algeria: Arabian Journal of Geosciences, 10, p. 1-46.

Mekahli, L., Elmi, S. and Benhamou, M., 2004. Biostratigraphy, sedimentology and tectono-eustatic events of the Lower and Middle Jurassic of the Ksour Mountains (Western Saharian Atlas, Southern Algeria): International Geological Congress, 32, Florence.

Merino-Tomé, Ó., Della Porta, G., Pierre, A. and Kenter, J.A., 2017. Intact seismic-scale platforms and ramps in the Lower to Middle Jurassic of Morocco: Implications for stratal anatomy and lithofacies partitioning: AAPG Bulletin, 101, p. 205-513.

Miall, A., 2014. The emptiness of the stratigraphic record: A preliminary evaluation of missing time in the Mesaverde Group, Book Cliffs, Utah, USA: Journal of Sedimentary Research, 84, p. 457-469.

Michard, A., 1976. Eléments de géologie Marocaine: Notes et Mémoires du Service Géologique du Maroc, 252, p. 408.

Michard, A., Saddiqi, O., Chalouan, A. and de Lamotte, D.F., 2008. Continental Evolution: The Geology of Morocco: Springe, $424 p$.

Michard, A., Soulaimani, A., Hoepffner, C., Ouanaimi, H., Baidder, L., Rjimati, E.C. and Saddiqi, O., 2010. The South-Western Branch of the Variscan Belt: Evidence from Morocco: Tectonophysics, 492, p. 1-24.

Michel, L., Ehlers, T.A., Glotzbach, C. and Adams, B.A., 2017. Increase in localized exhumation with the onset of Pleistocene glaciation, Olympic Mountains (USA): New insights from thermochronometer data and numerical modeling: EGU General Assembly, Vienna.

Michon, L. and Merle, O., 2003. Mode of lithospheric extension: Conceptual models from analogue modeling: Tectonics, 22, TC1028.

Miles, P., Bouysse, P., and De Souza, K., 2012. Structural Map of the Atlantic Ocean, CCGM-CGMW. 
Missenard, Y., 2006. Le relief des Atlas Marocains: Contribution des processus asthénosphériques et du raccourcissement crustal, aspects chronologiques: Université de Cergy Pontoise, Ph.D. Thesis, 236 p.

Missenard, Y. and Cadoux, A., 2011. Can Moroccan Atlas lithospheric thinning and volcanism be induced by Edge-Driven Convection?: Terra Nova, 24, p. 27-33.

Missenard, Y., Saddiqi, O., Barbarand, J., Leturmy, P., Ruiz, G., Haimer, El, F.-Z. and Frizon de Lamotte, D., 2008. Cenozoic denudation in the Marrakech High Atlas, Morocco: insight from apatite fission-track thermochronology: Terra Nova, 20, p. 221-228.

Monbaron, M. and Taquet, P., 1981. Découverte du squelette complet d'un grand Cétiosaure (Dinosaure Sauropode) dans le bassin jurassique moyen de Tilougguit (Haut-Atlas central, Maroc): Compte Rendu de l'Academie des Sciences de Paris, 292, p. 243-246.

Montero, P., Haissen, F., Mouttaqi, A., Molina, J.F., Errami, A., Sadki, O., Cambeses, A. and Bea, F., 2016. Contrasting SHRIMP $\mathrm{U}-\mathrm{Pb}$ zircon ages of two carbonatite complexes from the peri-cratonic terranes of the reguibat shield: Implications for the lateral extension of the West African craton: Gondwana Research, 38, p. 238-250.

Moore, M.E., Gleadow, A.J. and Lovering, J.F., 1986. Thermal evolution of rifted continental margins: New evidence from fission tracks in basement apatites from southeastern Australia: Earth and Planetary Science Letters, 78, p. 255-270.

Moragas, M., Verges, J., Nalpas, T., Saura, E., MartínMartín, J.-D., Messager, G. and Hunt, D.W., 2017. The impact of syn- and post-extension prograding sedimentation on the development of salt-related rift basins and their inversion: Clues from analogue modelling: Marine and Petroleum Geology, 88, p. 9851003.

Mosar, J., Lewis, G. and Torsvik, T.H., 2002. North Atlantic sea-floor spreading rates: implications for the Tertiary development of inversion structures of the Norwegian-Greenland Sea: Journal of the Geological Society, 159, p. 503-515.

Mulder, E.W., Bardet, N., Godefroit, P. and Jagt, J.W., 2000. Elasmosaur remains from the Maastrichtian type area, and a review of latest Cretaceous elasmosaurs (Reptilia, Plesiosauroidea): Bulletin de l'Institut royal des Sciences naturelles de Belgique, 70, p. 161-178.

Müller, R.D., Hassan, R., Gurnis, M., Flament, N. and Williams, S.E., 2018. Dynamic topography of passive continental margins and their hinterlands since the Cretaceous: Gondwana Research, 53, p. 225-251.

Müller, R.D., Sdrolias, M., Gaina, C. and Roest, W.R., 2008. Age, spreading rates, and spreading asymmetry of the world's ocean crust: Geochemistry Geophysics Geosystems, 9, Q04006.

Nemčok, M., Stuart, C., Segall, M.P. and Allen, R.B., 2005. Structural development of southern Morocco: Interaction of tectonics and deposition: Annual Bob F. Perkins Research Conference, 25, Houston p. 151-202.

Neumaier, M., Back, S., Littke, R., Kukla, P.A., Schnabel, M. and Reichert, C., 2015. Late Cretaceous to Cenozoic geodynamic evolution of the Atlantic margin offshore Essaouira (Morocco): Basin Research, 28, p. 712-730.

Nouri, J., Díaz-Martínez, I. and Pérez-Lorente, F., 2011. Tetradactyl Footprints of an Unknown Affinity Theropod Dinosaur from the Upper Jurassic of Morocco (C. Lalueza-Fox, Ed.): PLoS ONE, 6, p. e268827.

Nürnberg, D. and Müller, R.D., 1991. The tectonic evolution of the South Atlantic from Late Jurassic to present: Tectonophysics, 191, p. 27-53.

Olsen, K.H., 1995. Continental rifts: Evolution, structure, tectonics: Elsevier, $485 \mathrm{p}$.

Olsen, P.E., 1997. Stratigraphic record of the early Mesozoic breakup of Pangea in the LaurasiaGondwana rift system: Annual Review of Earth and Planetary Sciences, 25, p. 337-401.

Ouajhain, B., Daoudi, L., Laduron, D., Rocha, F. and Naud, J., 2011. Jurassic Clay Mineral Sedimentation Control Factors in the Essaouira Basin (Western High Atlas, Morocco): Geologica Belgica, 14, p. 129-141.

Oukassou, M., Charrière, A., Lagnaoui, A., Gibb, S., Michard, A. and Saddiqi, O., 2016. First occurrence of the Ichnogenus Selenichnites from the Middle Jurassic Strata of the Skoura Syncline (Middle Atlas, Morocco). Palaeoecological and palaeoenvironmental context: Comptes Rendus Palevol, 15, p. 461-471.

Oukassou, M., Saddiqi, O., Barbarand, J., Sebti, S., Baidder, L. and Michard, A., 2013. Post-Variscan exhumation of the Central Anti-Atlas (Morocco) constrained by zircon and apatite fission-track thermochronology: Terra Nova, 25, p. 151-159.

Ourribane, M., Chellai, E.H. and Zaghbib-Turki, D., 2000. Rôle des microbialites et des «microencroûtants» dans la lithification récifale: Exemples du Jurassique supérieur de I'Atlas maghrébin (Maroc et Tunisie): Comptes Rendus de l'Académie des Sciences, 330, p. 407-414.

Oveisi, B., Lavé, J. and van der Beek, P., 2007. Rates and processes of active folding evidenced by Pleistocene terraces at the central Zagros front (Iran). In: Thrust Belts and Foreland Basins, Springer, p. 267-287. 
Pagel, M., Barbarand, J., Beaufort, D., Gautheron, C. and Pironon, J., 2014. Bassins sédimentaires Les marqueurs de leur histoire thermique: Ed Sciences, Société Géologique de France, 226 p.

Paton, D. A., Pindell, J., McDermott, K., Bellingham, P. and Horn, B., 2017. Evolution of seaward-dipping reflectors at the onset of oceanic crust formation at volcanic passive margins: Insights from the South Atlantic: Geology, 45, p. 439-442.

Pichel, L.M., Finch, E., Huuse, M. and Redfern, J., 2017. The influence of shortening and sedimentation on rejuvenation of salt diapirs: A new Discrete-Element Modelling approach: Journal of Structural Geology, 104, p. 61-79.

Piqué, A. and Laville, E., 1996. The central Atlantic rifting: Reactivation of Palaeozoic structures?: Journal of Geodynamics, 21, p. 235-255.

Piqué, A., Dahmani, M., Jeannette, D. and Bahi, L., 1987. Permanence of structural lines in Morocco from Precambrian to present: Journal of African Earth Sciences, 6, p. 247-256.

Piqué, A., Soulaimani, A., Laville, E., Amrhar, M., Bouabdelli, M., Hoepffner, C. and Chalouan, A., 2006. Géologie du Maroc: Editions Geode, 287 p.

Piqué, A., Tricart, P., Guiraud, R., Laville, E., Bouaziz, S., Amrhar, M. and Ouali, R.A., 2002. The MesozoicCenozoic Atlas belt (North Africa): An overview: Geodinamica Acta, 15, p. 185-208.

Pratt, J.R., Barbeau, D.L., Jr., Garver, J.I., Emran, A. and Izykowski, T.M., 2015. Detrital Zircon Geochronology of Mesozoic Sediments in the Rif and Middle Atlas Belts of Morocco: Provenance Constraints and Refinement of the West African Signature: The Journal of Geology, 123, p. 177-200.

Press, W.H., Flannery, B.P., Teukolsky, S.A. and Vetterling, W.T., 1992. Numerical Recipes in FORTRAN 77. In: Volume 1. Fortran Numerical Recipes: Cambridge University Press. 1010 p.

Raddi, Y., Baidder, L., Tahiri, M. and Michard, A., 2007. Variscan deformation at the northern border of the West African Craton, eastern Anti-Atlas, Morocco: Compression of a mosaic of tilted blocks: Bulletin de la Societe Geologique de France, 178, p. 343-352.

Rage, J.-C., 1976. Les Squamates du Miocène de Beni Mellal, Maroc: Géologie méditerranéenne, 3, p. 57-69.

Rage, J.-C. and Wouters, G., 1979. Découverte du plus ancien Palaeopheidé (Reptilia, Serpentes) dans le Maestrichtien du Maroc: Geobios, 12, p. 293-296.

Ranke, U., Rad, von, U. and Wissmann, G., 1982. Stratigraphy, Facies and Tectonic Development of the
On- and Offshore Aaiun-Tarfaya Basin - A Review. In: Geology of the Northwest African Continental Margin, Springer, p. 86-105.

Read, J.F., Grotzinger, J.P., Bova, J.A. and Koerschner, W.F., 1986. Models for generation of carbonate cycles: Geology, 14, p. 107-110.

Reiners, P.W., 2005. Zircon (U-Th)/He Thermochronometry: Reviews in Mineralogy and Geochemistry, 58, p. 151-179.

Ring, U., Brandon, M.T., Willett, S.D. and Lister, G.S., 1999. Exhumation processes: Geological Society, London, Special Publications, 154, p. 1-27.

Robert-Charrue, C., 2006. Géologie structurale de I'Anti-Atlas oriental, Maroc: Université de Neuchâtel, Ph.D. Thesis, $224 \mathrm{p}$.

Robert-Charrue, C. and Burkhard, M., 2008. Inversion tectonics, interference pattern and extensional faultrelated folding in the Eastern Anti-Atlas, Morocco: Swiss Journal of Geosciences, 101, p. 397-408.

Rohrman, M., van der Beek, P. and Andriessen, P., 1994. Syn-rift thermal structure and post-rift evolution of the Oslo Rift (southeast Norway): New constraints from fission track thermochronology: Earth and Planetary Science Letters, 127, p. 39-54.

Romagny, A., Münch, P., Cornée, J.J., Corsini, M., Azdimousa, A., Melinte-Dobrinescu, M.C., Drinia, H., Bonno, M., Arnaud, N., Monié, P., Quillévéré, F. and Ben Moussa, A., 2014. Late Miocene to present-day exhumation and uplift of the Internal Zone of the Rif chain: Insights from low-temperature thermochronometry and basin analysis: Journal of Geodynamics, 77, p. 39-55.

Rosenbaum, G., Lister, G.S. and Duboz, C., 2002. Relative motions of Africa, Iberia and Europe during Alpine orogeny: Tectonophysics, 359, p. 117-129.

Rossi, C., Kälin, O., Arribas, J. and Tortosa, A., 2002. Diagenesis, provenance and reservoir quality of Triassic TAGI sandstones from Ourhoud field, Berkine (Ghadames) Basin, Algeria: Marine and Petroleum Geology, 19, p. 117-142.

Rougier, S., Missenard, Y., Gautheron, C., Barbarand, J., Zeyen, H., Pinna, R., Liégeois, J.P., Bonin, B., Ouabadi, A., Derder, M.E.M. and Frizon De Lamotte, D., 2013. Eocene exhumation of the Tuareg Shield (Sahara Desert, Africa): Geology, 41, p. 615-618.

Ruiz, G.M., Helg, U., Negro, F., Adatte, T. and Burkhard, M., 2008. Illite crystallinity patterns in the Anti-Atlas of Morocco: Swiss Journal of Geosciences, 101, p. 387395. 
Ruiz, G.M.H., Sebti, S., Negro, F., Saddiqi, O., Frizon de Lamotte, D., Stockli, D., Foeken, J., Stuart, F., Barbarand, J. and Schaer, J.P., 2011. From central Atlantic continental rift to Neogene uplift - western Anti-Atlas (Morocco): Terra Nova, 23, p. 35-41.

Rusmore, M.E., Woodsworth, G.J. and Gehrels, G.E., 2005. Two-stage exhumation of midcrustal arc rocks, Coast Mountains, British Columbia: Tectonics, 24, TC1750.

Sabil, N., 1995. La datation par traces de fission: Aspects méthodologiques et applications thermochronologiques en contexte alpin et de marge continentale: Université de Grenoble, Ph.D. Thesis, 245 p.

Saddiqi, O., Haimer, El, F.Z., Michard, A., Barbarand, J., Ruiz, G.M.H., Mansour, E.M., Leturmy, P. and de Lamotte, D.F., 2009. Apatite fission-track analyses on basement granites from south-western Meseta, Morocco: Paleogeographic implications and interpretation of AFT age discrepancies: Tectonophysics, 475, p. 29-37.

Saddiqi, O., Rjimati, E., Michard, A., Soulaimani, A. and Ouanaimi, H., 2015. Recommended geoheritage trails in Southern Morocco: A 3 Ga record between the Sahara Desert and the Atlantic Ocean. In: From Geoheritage to Geoparks, Springer, p. 91-108.

Sahabi, M., Aslanian, D. and Olivet, J.-L., 2004. Un nouveau point de départ pour I'histoire de l'Atlantique central: Comptes Rendus Geoscience, 336, p. 10411052.

Saint-Martin, J.-P., 1990. Les formations récifales coralliennes du Miocène supérieur d'Algérie et du Maroc: Mémoires du Muséum National d'Histoires Naturelles de Paris, 56, p. 1-373.

Samaka, F. and Bouhaddioui, D., 2003. Evaluation du Potentiel Petrolier du Bassin de Souss et de I'Offshore d'Agadir: ONHYM, Rapport inédit, 34 p.

Sanders, M.T., Bardin, J., Benzaggagh, M. and Cecca, F., 2015. Early Toarcian (Jurassic) belemnites from northeastern Gondwana (South Riffian ridges, Morocco): Paläontologische Zeitschrift, 89, p. 51-62.

Saura, E., Verges, J., Martin-Martin, J.D., Messager, G., Moragas, M., Razin, P., Grelaud, C., Joussiaume, R., Malaval, M., Homke, S. and Hunt, D.W., 2014. Syn- to post-rift diapirism and minibasins of the Central High Atlas (Morocco): The changing face of a mountain belt: Journal of the Geological Society, 171, p. 97-105.

Schettino, A. and Macchiavelli, C., 2016. Plate kinematics of the central Atlantic during the Oligocene and early Miocene: Geophysical Journal International, 205, p. 408-426.
Schlanger, S.O. and Jenkyns, H.C., 1976. Cretaceous Oceanic Anoxic Events: Geologie en Mijnbouw, 55, p. 179-184.

Sebai, A., Feraud, G., Bertrand, H. and Hanes, J., 1991. ${ }^{40} \mathrm{Ar} /{ }^{39} \mathrm{Ar}$ dating and geochemistry of tholeiitic magmatism related to the early opening of the Central Atlantic rift: Earth and Planetary Science, 104, p. 455472.

Sebti, S., 2011. Mouvements verticaux de l'Anti-Atlas occidental marocain (Kerdous \& Ifni): Thermochronologie par traces de fission: Université Hassan II, Ph.D. Thesis, $172 \mathrm{p}$.

Sebti, S., Saddiqi, O., Haimer, El, F.-Z., Michard, A., Ruiz, G., Bousquet, R., Baidder, L. and Frizon de Lamotte, D., 2009. Vertical movements at the fringe of the West African Craton: First zircon fission track datings from the Anti-Atlas Precambrian basement, Morocco: Comptes Rendus Geoscience, 341, p. 71-77.

Sehrt, M., 2014. Variscan to Neogene long-term landscape evolution at the Moroccan passive continental margin (Tarfaya Basin and western AntiAtlas): University of Heidelberg, Ph.D. Thesis, 174 p.

Sehrt, M., Glasmacher, U.A., Stockli, D.F., Jabour, H. and Kluth, O., 2017b. Meso-/Cenozoic long-term landscape evolution at the southern Moroccan passive continental margin, Tarfaya Basin, recorded by lowtemperature thermochronology: Tectonophysics, 717, p. 499-518.

Sehrt, M., Glasmacher, U.A., Stockli, D.F., Jabour, H. and Kluth, O., 2017a. The southern Moroccan passive continental margin: An example of differentiated longterm landscape evolution in Gondwana: Gondwana Research, 53, p. 129-144.

Segev, A., 2002. Flood basalts, continental breakup and the dispersal of Gondwana: evidence for periodic migration of upwelling mantle flows (plumes): EGU Stephan Mueller Special Publication Series, 2, p. 171191.

Sébrier, M., Siame, L., Zouine, E.M., Winter, T., Missenard, Y. and Leturmy, P., 2006. Active tectonics in the Moroccan High Atlas: Comptes Rendus Geoscience, 338, p. 65-79.

Scotese, C. R., 2012. The Paleomap Project: www.scotese.com.

Shuster, D.L., Flowers, R.M. and Farley, K.A., 2006. The influence of natural radiation damage on helium diffusion kinetics in apatite: Earth and Planetary Science Letters, 249, p. 148-161.

Sibuet, J.-C., Rouzo, S., Srivastava, S., Dehler, S., Deptuck, M. and Karim, A., 2012. Plate tectonic reconstructions and paleogeographic maps of the 
central and North Atlantic oceans: Canadian Journal of Earth Sciences, 49, p. 1395-1415.

Silva, P.F., Marques, F.O., Henry, B., Madureira, P., Hirt, A.M., Font, E. and Lourenço, N., 2010. Thick dyke emplacement and internal flow: A structural and magnetic fabric study of the deep-seated dolerite dyke of Foum Zguid (southern Morocco): Journal of Geophysical Research, 115, B12108.

Silva, P.F., Marques, F.O., Henry, B., Mateus, A., Lourenço, N. and Miranda, J.M., 2004. Preliminary results of a study of magnetic properties in the FoumZguid dyke (Morocco): Physics and Chemistry of the Earth, 29, p. 909-920.

Snedden, J.W. and Liu, C., 2010. A compilation of Phanerozoic sea-level change, coastal onlaps and recommended sequence designations: Search and discovery article, 40594.

Soulaimani, A., 1998. Interactions socle/couverture dans I'Anti-Atlas occidental (Maroc): Rifting finiProtérozoïque et orogenèse hercynienne: Université Cadi-Ayyad Marrakech, Ph.D. Thesis, 215 p.

Soulaimani, A. and Burkhard, M., 2008. The Anti-Atlas chain (Morocco): The southern margin of the Variscan belt along the edge of the West African craton: Geological Society, London, Special Publications, 297, p. 433-452.

Soulaimani, A., Michard, A., Ouanaimi, H., Baidder, L., Raddi, Y., Saddiqi, O. and Rjimati, E.C., 2014. Late Ediacaran-Cambrian structures and their reactivation during the Variscan and Alpine cycles in the Anti-Atlas (Morocco): Journal of African Earth Sciences, 98, p. 94112.

Stampfli, G.M. and Borel, G.D., 2002. A plate tectonic model for the Paleozoic and Mesozoic constrained by dynamic plate boundaries and restored synthetic oceanic isochrons: Earth and Planetary Science Letters, 196, p. 17-33.

Steiner, C., Hobson, A., Favre, P., Stampfli, G.M. and Hernandez, J., 1998. Mesozoic sequence of Fuerteventura (Canary Islands): Witness of Early Jurassic sea-floor spreading in the central Atlantic: Geological Society of America Bulletin, 110, p. 13041317.

Stets, J., 1992. Mid-Jurassic events in the western High Atlas (Morocco): Geologische Rundschau, 81, p. 69-84.

Strobl, M., Hetzel, R., Niedermann, S., Ding, L. and Zhang, L., 2012. Landscape evolution of a bedrock peneplain on the southern Tibetan Plateau revealed by in situ-produced cosmogenic ${ }^{10} \mathrm{Be}$ and ${ }^{21} \mathrm{Ne}$ : Geomorphology, 153-154, p. 192-204.
Summerfield, M.A., Stuart, F.M., Cockburn, H., Sugden, D.E., Denton, G.H., Dunai, T. and Marchant, D.R., 1999. Long-term rates of denudation in the Dry Valleys, Transantarctic Mountains, southern Victoria Land, Antarctica based on in-situ-produced cosmogenic Ne21: Geomorphology, 27, p. 113-129.

Swezey, C.S., 2009. Cenozoic stratigraphy of the Sahara, Northern Africa: Journal of African Earth Sciences, 53, p. 89-121.

Sømme, T.O., Helland-Hansen, W., Martinsen, O.J. and Thurmond, J.B., 2009. Relationships between morphological and sedimentological parameters in source-to-sink systems: A basis for predicting semiquantitative characteristics in subsurface systems: Basin Research, 21, p. 361-387.

Şengör, A., Özeren, S., Genç, T. and Zor, E., 2003. East Anatolian high plateau as a mantle-supported, northsouth shortened domal structure: Geophysical Research Letters, 30, 8045.

Tabuce, R., Adnet, S., Cappetta, H., Noubhani, A. and Quillevere, F., 2005. Aznag (Ouarzazate basin, Morocco), a new African middle Eocene (Lutetian) vertebrate-bearing locality with selachians and mammals: Bulletin de la Société Géologique de France, 176, p. 381-400.

Tagami, T. and O'Sullivan, P.B., 2005. Fundamentals of fission-track thermochronology: Reviews in Mineralogy and Geochemistry, 58, p. 19-47.

Tan, X.-B., Lee, Y.-H., Xu, X.-W. and Cook, K.L., 2017. Cenozoic exhumation of the Danba antiform, eastern Tibet: Evidence from low-temperature thermochronology: Lithosphere, 9, p. 534-544.

Tankard, A.J. and Welsink, H.J., 1989. Mesozoic extension and styles of basin formation in Atlantic Canada: Extensional tectonics and stratigraphy of the North Atlantic margins: AAPG Memoir, 46, p. 175-195.

Tassone, D.R., Holford, S.P., Hillis, R.R. and Tuitt, A.K., 2012. Quantifying Neogene plate-boundary controlled uplift and deformation of the southern Australian margin: Geological Society, London, Special Publications, 367, p. 91-110

Teixell, A., Arboleya, M.-L., Julivert, M. and Charroud, M., 2003. Tectonic shortening and topography in the central High Atlas (Morocco): Tectonics, 22, TC1051.

Teixell, A., Ayarza, P., Zeyen, H., Fernandez, M. and Arboleya, M.-L., 2005. Effects of mantle upwelling in a compressional setting: The Atlas Mountains of Morocco: Terra Nova, 17, p. 456-461.

Teixell, A., Bertotti, G., de Lamotte, D.F. and Charroud, M., 2009. The geology of vertical movements of the lithosphere: An overview: Tectonophysics, 475, p. 1-8. 
Tello, C.A., 2006. Annealing experiments on induced fission tracks in apatite: Measurements of horizontalconfined track lengths and track densities in basal sections and randomly oriented grains: American Mineralogist, 91, p. 252-260.

Thomas, R.J., Chevallier, L.P., Gresse, P.G., Harmer, R.E., Eglington, B.M., Armstrong, R.A., De Beer, C.H., Martini, J., De Kock, G.S., Macey, P.H. and Ingram, B.A., 2002. Precambrian evolution of the Sirwa window, Anti-Atlas orogen, Morocco: Precambrian Research, 118, p. 1-57.

Thomas, R.J., Fekkak, A., Ennih, N., Errami, E., Loughlin, S.C., Gresse, P.G., Chevallier, L.P. and Liégeois, J.P., 2004. A new lithostratigraphic framework for the AntiAtlas Orogen, Morocco: Journal of African Earth Sciences, 39, p. 217-226.

Torsvik, T.H., Van der Voo, R., Meert, J.G. and Mosar, J., 2001. Reconstructions of the continents around the North Atlantic at about the $60^{\text {th }}$ parallel: Earth and Planetary Science Letters, 187, p. 55-69.

Touil, A., Vegas, R., Hafid, A., Palomino, R., Rizki, A., Palencia-Ortas, A. and Ruiz-Martınez, V.C., 2008. Petrography, mineralogy and geochemistry of the Ighrem diabase dyke (Anti-Atlas, Southern Morocco): Revista de la Sociedad Geológica de España, 21, p. 2533.

Trappe, J., 1991. Stratigraphy, facies distribution and paleogeography of the marine Paleogene from the Western High Atlas, Morocco: Neues Jahrbuch für Geologie und Paläontologie, 180, p. 279-321.

van den Bogaard, P., 2013. The origin of the Canary Island Seamount Province - New ages of old seamounts: Scientific Reports, 3, 21077.

van der Beek, P., Mbede, E., Andriessen, P. and Delvaux, D., 1998. Denudation history of the Malawi and Rukwa Rift flanks (East African Rift System) from apatite fission track thermochronology: Journal of African Earth Sciences, 26, p. 363-385.

van Hinsbergen, D.J.J., de Groot, L.V., van Schaik, S.J., Spakman, W., Bijl, P.K., Sluijs, A., Langereis, C.G. and Brinkhuis, H., 2015. A Paleolatitude Calculator for Paleoclimate Studies: PLOS ONE, 10, p. e0126946-21.

Vermeesch, P., 2009. RadialPlotter: A Java application for fission track, luminescence and other radial plots: Radiation Measurements, 44, p. 409-410.

Vermeesch, P. and Tian, Y., 2014. Thermal history modelling: HeFTy vs. QTQt: Earth Science Reviews, 139, p. 279-290.

Vernon, A.J., van der Beek, P.A., Sinclair, H.D. and Rahn, M.K., 2008. Increase in late Neogene denudation of the European Alps confirmed by analysis of a fission-track thermochronology database: Earth and Planetary Science Letters, 270, p. 316-329.

Vincent, C.J., Rowley, W.J. and Monaghan, A.A., 2010. Thermal and burial history modelling in the Midlothian-Leven syncline in the Midland Valley of Scotland using BasinMod and HotPot: Scottish Journal of Geology, 46, p. 125-142.

Vogl, J.J., Min, K., Carmenate, A., Foster, D.A. and Marsellos, A., 2014. Miocene regional hotspot-related uplift, exhumation, and extension north of the Snake River Plain: Evidence from apatite (U-Th)/He thermochronology: Lithosphere, 6, p. 108-123.

Walsh, G.J., Aleinikoff, J.N., Benziane, F., Yazidi, A. and Armstrong, T.R., 2002. U-Pb zircon geochronology of the Paleoproterozoic Tagragra de Tata inlier and its Neoproterozoic cover, western Anti-Atlas, Morocco: Precambrian Research, 117, p. 1-20.

Watts, A.B., 2012. Models for the evolution of passive margins. In: Regional Geology and Tectonics: Phanerozoic Rift Systems and Sedimentary Basins, Cambridge University Press, p. 35-57.

Weisheit, A., Bons, P.D., Danišík, M. and Elburg, M.A., 2014. Crustal-scale folding: Palaeozoic deformation of the Mt Painter Inlier, South Australia: Geological Society, London, Special Publications, 394, p. 53-77.

Wells, M., Morton, A. and Frei, D., 2017. Provenance of Lower Cretaceous clastic reservoirs in the Middle East: Journal of the Geological Society, 174, p. 1048-1061.

Wenke, A., 2014. Sequence stratigraphy and basin analysisof the Meso- to Cenozoic Tarfaya-Laâyoune Basins, on- and offshore Morocco: University of Heidelberg, Ph.D. Thesis, 189 p.

Westaway, R., Hssaine, A.A., Demir, T. and Beck, A., 2009. Field reconnaissance of the Anti-Atlas coastline, Morocco: Fluvial and marine evidence for Late Cenozoic uplift: Global and Planetary Change, 68, p. 297-310.

Whipple, K.X., 2009. The influence of climate on the tectonic evolution of mountain belts: Nature Geoscience, 2, p. 97-104.

Wildman, M., Brown, R., Watkins, R., Carter, A., Gleadow, A. and Summerfield, M., 2015. Post break-up tectonic inversion across the southwestern cape of South Africa: New insights from apatite and zircon fission track thermochronometry: Tectonophysics, 654, p. 30-55.

Wipf, M., Glasmacher, U.A., Stockli, D.F., Emmerich, A., Bechstädt, T. and Baur, H., 2009. Reconstruction of the differentiated long-term exhumation history of Fuerteventura, Canary Islands, Spain, through fission- 
track and (U-Th-Sm)/He data: International Journal of Earth Sciences, 99, p. 675-686.

Withjack, M.O. and Schlische, R.W., 2005. A Review of Tectonic Events on the Passive Margin of Eastern North America: Bob S. Perkins Research Conference, 25, Houston, p. 203-235.

Wold, C.N. and Hay, W.W., 1990. Estimating Ancient Sediment Fluxes: American Journal of Science, 290, p. 1069-1089.

Wrtiti, M.E., Broutin, J., Freytet, P., Larhrib, M. and Toutin-Morin, N., 1990. Continental deposits in Permian basins of the Mesetian Morocco, geodynamic history: Journal of African Earth Sciences, 10, p. 361368 .

Yamato, P., Husson, L., Becker, T.W. and Pedoja, K., 2013. Passive margins getting squeezed in the mantle convection vice: Tectonics, 32, p. 1559-1570.

Yazidi, A., Benziane, F., Hassenforder, B., Destombes, J., Hollard, H., Bourgin, R. and Oliva, P., 1991. Carte Géologique du Maroc: Tiznit (1/100,000): Notes et Mémoires du Service Géologique du Maroc, 360.

Yazidi, A., Benziane, F., Hollard, H., Oliva, P. and Destombes, J., 1986. Carte Géologique du Maroc: Sidi Ifni (1/100,000): Notes et Mémoires du Service Géologique du Maroc, 310.
Ye, J., Chardon, D., Rouby, D., Guillocheau, F., Dall'asta, M., Ferry, J.-N. and Broucke, O., 2017. Paleogeographic and structural evolution of northwestern Africa and its Atlantic margins since the early Mesozoic: Geosphere, 13, 1254-1284.

Youssi, El, M., 1993. La Hamada du Guir (SE marocain). Lithostratigraphie, encroutements carbonatés et argilogenèse: Université de Grenoble, Ph.D. Thesis, 174 p.

Zarhloule, Y., 2004. Le gradient géothermique profond du Maroc: Détermination et cartographie: Bulletin de I'Institut Scientifique de Rabat, 26, p. 11-25.

Zeyen, H., Ayarza, P., Fernàndez, M., and Rimi, A., 2005. Lithospheric structure under the western African-European plate boundary: A transect across the Atlas Mountains and the Gulf of Cadiz. Tectonics, 24, TC2001.

Zouhri, S., Gingerich, P.D., Elboudali, N., Sebti, S., Noubhani, A., Rahali, M. and Meslouh, S., 2014. New marine mammal faunas (Cetacea and Sirenia) and sea level change in the Samlat Formation, Upper Eocene, near Ad-Dakhla in southwestern Morocco: Comptes Rendus Palevol, 13, p. 599-610.

Zouhri, S., Kchikach, A., Saddiqi, O., Haimer, El, F.Z., Baidder, L. and Michard, A., 2008. The Cretaceoustertiary plateaus. In: Continental Evolution: The Geology of Morocco, Springer, p. 331-358. 


\section{Acknowledgements}

Many deserve to be thanked for their help in this research project. First and foremost, Giovanni Bertotti and Joep Storms are thanked for initiating this Ph.D. project. The Netherlands research centre for Integrated Solid Earth Science (ISES) is thanked for funding this project. The North Africa Research Group (NARG) and its leader, Jonathan Redfern, are thanked for supporting this research. The sponsors of the NARG are thanked for many valuable inputs. The four independent and the reserve members of the defence committee, Delphine Rouby, Antonio Teixell, Allard Martinius, Mohamed Gouiza, and David Bruhn, are thanked for their comments and for judging my work on what is for me, a very special day.

Giovanni Bertotti and Joep Storms are thanked for proofreading this Thesis. Helena van der Vegt, Max Holicki, Julien Chimot, Kevin Bisdom, Reuben Zotz-Wilson and Boris Boullanger are thanked for their suggestions regarding the propositions. Koen van Toorenenburg is thanked for translating this Thesis' summary to Dutch. Helena van der Vegt, Kevin Bisdom, and Koen van Toorenenburg are thanked for their help with the defence ceremony. The presence of everybody who joins the ceremony and/or party afterwards is extremely appreciated.

I have had a very pleasant time as a Ph.D. candidate in Delft, and that is partly thanks to my supervisors: Giovanni B, Joep S, and Jonathan R. Special thanks to Giovanni; you somehow always knew the right rythmn for me. I am very grateful for all you have done and taught me.

From the NARG, I first wish to thank Tim L and Angel A. We started and went through this Ph.D. experience together, and it was awesome. That is also true for you guys - Aude DA, Leo PM, Jianpeng W, Emmanuel R, Nawar A, Richard N, Kara E, and Max C. I can only think of one thing to say here: Let's write cool papers together! Amongst the NARG sponsor members, I wish to thank the following geoscientists for sparkling ideas that ended up in this Thesis: Evelina D (Repsol), Damian O'G (Chevron), Enrique C (Kosmos), William L (Kosmos), Eleanor C (Cairn) and Aram D (Hess).

I had the pleasure of supervising several brilliant students. While being an excellent experience from my future career, they also helped me a great deal with my research: Sanne B, Esmee dB, Bas N, Michiel V, Maurits dJ, Niek M, Annemijn vdB, and Christian $K$, thank you. I also had the chance to participate in several courses as a TA, for which I am grateful to Jan Kees B (B.Sc. fieldtrip), Gerhard D (M.Sc. Field Development Plan and Seismic Interpretation), Joep S (M.Sc. Geological Modelling), and Giovanni B (B.Sc. Geology). I especially enjoyed Vesc with you Jan Kees, and can only wish to return there again. Ralf $H$, thank you for settling me in the office, twice; Lydia B, Marlijn A, Margot $\mathrm{BP}$, Marja RvdK, and Marijke SvT thank you for countless logistic thingies you helped me with; Rita, thank you for keeping my desk clean and tidy. 
Last, for my Ph.D. project, I wish to warmly thank Mohamed G for all the geological and non-geological conversations we had together during the last four years.

This Thesis is my greatest achievement yet. It seems therefore only fitting to also thank the people that contributed to my well being over the last years.

Doing a Ph.D. would not be fun without fellow Ph.D.s and Post-Docs, and my true appreciation goes to them. So here it goes: From the 'fieldwork-lovers' section, Helena $v d V$, Kevin B, Koen vT, Cees W, Siddarth S, Runhai F, Andrea F, Quinten B, Thais E, Rodolfo O, Navid H, Pierre-Olivier B, Martha N, Rahul P, Santosh K, Youwei W, Nico H, and Stephan $\mathrm{dH}$; from the 'equation-geeks' section, Max H, Boris B, Sixue W, Carlos A, Reuben ZW, Lisanne D, Ranjani S, Joeri B, Matteo C, Iris H, Anne P, Gil A, Jan-Willem V, Myrna S, Chris R, Karlien S, Yohei N, and Niels G; from the 'foam-fanatics' section, Baptiste L, Alex D, and Richard B; and from the 'cloud-gazers' section, Julien C. To all of you, save Koen and Kevin, I am sorry for smuggling the Nerf guns in. I might slightly be responsible for the chaos they generated... Still, I hope you will forgive me and I thank you all so much.

I have also befriended the better halves of my favourite colleagues - Laurie $\mathrm{K}$ and Paul $v d V$ - and want to thank them for their friendship. Especially Laurie, thank you for all the cakes, all the sweets, all the birthday celebrations, and for all the little creatures we hunted together.

I would like to thank Cristophe C, Pierre-Luc T, and Alexandre P, because you guys are the best fieldwork mates and really good friends. Let's go hiking soon my beloved Crazy Eastwingers!

I come from Pasques, a village of about 250 inhabitants located somewhere in Burgundy. I wish to thank my dear friends Thibault D, Mathieu C, and Romain C with whom I grew up in that tiny village.

I got so far in my life thanks to the kindness of my parents, Laurence and Hervé, and my brother, Lilian. Thank you so much for all that you have done during the last thirty years. I extend my thanks to all the Chartons, Langs, Marzolfs, Truchots, and Vachets.

I very much appreciate to be part of Emilie's family. For nine years now, you have encouraged us in many regards, and for that I am deeply gratful. Thank you Chantal, Sam, Manon, Adam, Laura, Cheyenne, Maurice, and Jeanne. Sam, thanks for being the first non-scientist human who went through my Thesis.

And... Emilie. Thank you so much Emilie. I will spend years to make it up to you, but I will. You truly are the best. 


\section{Curriculum Vitæ}

Rémi Charton | Born in Dijon, France | 22-07-1987

B.Sc. | Earth Sciences | Université de Bourgogne | 2007-2011

M.Sc. | Sedimentology | Universitet i Troms $\varnothing$ \& Université de Bourgogne | 2011-2013

Ph.D. | Applied Geology | Delft University of Technology | 2014-2018

ORCID | 0000-0002-0064-256X

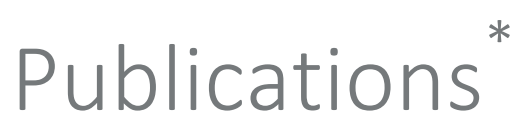

[Charton et al., 2018] The Sidi Ifni transect across the rifted margin of Morocco (Central Atlantic): Vertical movements constrained by low-temperature thermochronology.

Rémi Charton, Giovanni Bertotti, Angel Arantegui, and Luc Bulot.

In Journal of African Earth Sciences: Volume 141 of April 2018.

[Gouiza et al., 2017] Post-Variscan evolution of the Anti-Atlas belt of Morocco constrained from low-temperature geochronology.

Mohamed Gouiza, Rémi Charton, Giovanni Bertotti, Paul Andriessen, and Joep Storms. In International Journal of Earth Sciences: Volume 106 of March 2017

[Violette et al., 2016] Reactive transport modelling of carbonate cementation in a deep saline aquifer, the Middle Jurassic Oolithe Blanche Formation, Paris Basin, France.

Sophie Violette, Pierre-Yves Collin, Vincent Lagneau, Fabien Aubertin, Yasin Makhloufi, Rémi Charton, and Françoise Bergerat

In Comptes Rendus Geoscience: Volume 348 of September-October 2016

* Up-to-date lists of publications (including poster and oral presentations) are available on my Google Scholar and Research Gate pages. 

